\title{
Researching and Transforming Adult Learning and Communities
}

The Local/Global Context

Rob Evans, Ewa Kurantowicz and Emilio Lucio-Villegas (Eds.)

Sense Publishers

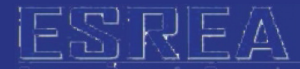


Researching and Transforming Adult Learning and Communities 


\section{RESEARCH ON THE EDUCATION AND LEARNING OF ADULTS}

\section{VOLUME 5}

\section{Series Editors}

(On behalf of the European Society for Research on the Education of Adults)

Emilio Lucio-Villegas (University of Seville, Spain)

Barbara Merrill (University of Warwick, United Kingdom)

Marcella Milana (Aarhus University, Denmark)

Henning Salling Olesen (Roskilde University, Denmark)

\section{Scope}

'Research on the Education and Learning of Adults' aims at providing an in-depth insight on the diversity of current research on adult education in diverse teaching/ learning contexts in both geographical and cultural terms in Europe. Research on adult education has been characterised by different intellectual traditions, theoretical and methodological approaches and which are still alive today in Europe from the north to the south and from the west to the east. This book series is edited by the European Society for Research on the Education of Adults (ESREA). The content of the series reflects the wide range of research activities undertaken by ESREA's members and networks such as: access, learning careers and identities; active citizenship; the professional development of adult educators; working life; the history of adult education; gender; local development and adult learning; ethnicity; older learners; adult education policies and biographical research. This book series will appeal to an international audience as it engages with current and relevant empirical research, a range of theoretical perspectives and knowledge thus stimulating debate, discussion and knowledge dissemination in the field in a democratic and heterogeneous way.

\section{Editorial Advisory Board}

Michal Bron Jr. (Södertörn University College, Sweden) Anja Heikkinen (University of Tampere, Finland)

Françoise F. Laot (University Paris-Descartes, France)

Linda Morrice (University of Sussex, United Kingdom)

Joanna Ostrouch-Kamińska (University of Warmia and Mazury, Poland)

Angela Pilch Ortega (Graz University, Austria)

Andreas Wallo (Linköping University, Sweden)

Georgios Zarifis (Aristotle University of Thessaloniki, Greece) 


\section{Researching and Transforming Adult Learning and Communities}

The Local/Global Context

Edited by

Rob Evans

University of Magdeburg, Germany

Ewa Kurantowicz

University of Lower Silesia, Wroclaw, Poland

and

Emilio Lucio-Villegas

University of Seville, Spain

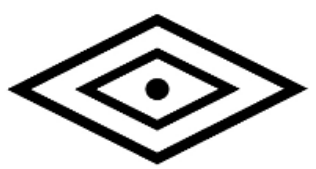

SENSE PUBLISHERS

ROTTERDAM/BOSTON/TAIPEI 
A C.I.P. record for this book is available from the Library of Congress.

ISBN: 978-94-6300-356-8 (paperback)

ISBN: 978-94-6300-357-5 (hardback)

ISBN: 978-94-6300-358-2 (e-book)

Published by: Sense Publishers,

P.O. Box 21858,

3001 AW Rotterdam,

The Netherlands

https://www.sensepublishers.com/

Cover image by Rob Evans

Printed on acid-free paper

All Rights Reserved (C) 2016 Sense Publishers

No part of this work may be reproduced, stored in a retrieval system, or transmitted in any form or by any means, electronic, mechanical, photocopying, microfilming, recording or otherwise, without written permission from the Publisher, with the exception of any material supplied specifically for the purpose of being entered and executed on a computer system, for exclusive use by the purchaser of the work. 


\section{TABLE OF CONTENTS}

The European Society for Research on the Education of Adults (ESREA) vii

1. Introduction 1

Rob Evans, Ewa Kurantowicz and Emilio Lucio-Villegas

\section{Section I: The Bigger Picture}

2. Towards a Knowledge Democracy Movement

Budd L. Hall

3. A Tramp Shining: The Popular (Community) Educator in the Age of Lifelong Learning

Emilio Lucio-Villegas and António Fragoso

4. Symbolic Closing of Local Community and Reflexivity

Rozalia Ligus

5. The Results of Local Community Projects: Political and

Research Contexts

Anna Bilon and Ewa Kurantowicz

\section{Section II: Adult Learning and Communities}

6. Learning Citizenship in the Community: Young Adults,

Participation and Democracy

Pyollim Hong and Jim Crowther

7. Adult Literacy and Empowerment: Learning for Freedom

Chris Parson

8. Social Capital, Adult Learning and Equality Adrianna Nizińska

9. "Why Choose One Hand Over the Other When We Can Use the Best of Two?": Adult Educators' Perspectives on Adult Education Isabel Gomes and Alcides A. Monteiro

10. Developing Minority Communities against the Background of the Necessary Dream of Returning to the Homeland

Paul de Roo

11. Adult Literacy Participants in Turkey

Özlem Ünlühisarcıklı 


\section{Section III: Learning in Social Movements and Social Change}

12. The Involvement of Women in Training: A Step Towards an Emancipatory Community Development Process

António Fragoso and Edmée Ollagnier

13. Researching and Sharing Power with a Learning Community Lyn Tett

14. Adult Education for Social Transformation in North Eastern Algarve Joaquim do Arco

15. Learning and Local Change in Social Movements in Chiapas, Mexico Angela Pilch Ortega

16. Social Movements and Adult Learning: A Story of the Women in the Environmental Social Movement in Turkey

Onur Seçkin 


\section{THE EUROPEAN SOCIETY FOR RESEARCH ON THE EDUCATION OF ADULTS (ESREA)}

ESREA is a European scientific society. It was established in 1991 to provide a European-wide forum for all researchers engaged in research on adult education and learning and to promote and disseminate theoretical and empirical research in the field. Since 1991 the landscape of adult education and learning has changed to include more diverse learning contexts at formal and informal levels. At the same time there has been a policy push by the European Union, OECD, UNESCO and national governments to promote a policy of lifelong learning. ESREA provides an important space for these changes and (re)definition of adult education and learning in relation to research, theory, policy and practice to be reflected upon and discussed. This takes place at the triennial conference, network conferences and through the publication of books and a journal.

\section{ESREA RESEARCH NETWORKS}

The major priority of ESREA is the encouragement of co-operation between active researchers in the form of thematic research networks which encourage inter-disciplinary research drawing on a broad range of the social sciences. These research networks hold annual/biennial seminars and conferences for the exchange of research results and to encourage publications.

The current active ESREA networks are:

- Access, Learning Careers and Identities

- Active Democratic Citizenship and Adult Learning

- Adult Educators, Trainers and their Professional Development

- Between Global and Local: Adult Learning and Development

- Education and Learning of Older Adults

- Gender and Adult Learning

- History of Adult Education and Training in Europe

- Interrogating Transformative Processes in Learning: An International Exchange

- Life-history and Biographical Research

- Migration, Ethnicity, Racism and Xenophobia

- Policy Studies in Adult Education

- Working Life and Learning

\section{ESREA TRIENNIAL EUROPEAN RESEARCH CONFERENCE}

In order to encourage the widest possible forum for the exchange of ongoing research activities ESREA holds a triennial European Research Conference. The conferences 
have been held in Strobl (1995), Bruxelles (1998), Lisbon (2001), Wroclaw (2004), Seville (2007), Linköping (2010) and Berlin (2013).

\title{
ESREA JOURNAL
}

ESREA publishes a scientific open access journal entitled The European Journal for Research on the Education and Learning of Adults (RELA). All issues of the journal can be read at www.rela.ep.liu.se. You can also find more information about call for papers and submission procedures on this website.

\section{ESREA BOOKS}

ESREA's research networks and conferences have led to the publication of over forty books. A full list, giving details of the various publishers, and the books' availability, is on the ESREA website. ESREA's current book series is published in co-operation with Sense Publishers.

Further information on ESREA is available at www.esrea.org

\author{
Emilio Lucio-Villegas \\ Barbara Merrill \\ Marcella Milana \\ Henning Salling Olesen
}




\section{ROB EVANS, EWA KURANTOWICZ AND \\ EMILIO LUCIO-VILLEGAS}

\section{INTRODUCTION}

Can adult education and learning be understood without reference to community and people's daily lives? Our response is no, it cannot. We think that adult education can be understood if we look at the social life of people in communities, and this book is an attempt to recover this view.

We are living in a society in fast and continuous transition where one of the focal points of research is on social change. But social change is a complex process full of different realities. Two examples will suffice to shed some light on social change in communities.

On the one hand, we can consider the work of Clifford Geertz on the funeral rituals in Java between 1952 and 1954. He proposes a form of analysis that discriminates between logical-meaningful integration and causal-functional integration, sustaining that cultural factors and social structure are not mere reflections of one another:

In most societies, where change is a characteristic rather than an abnormal occurrence, we shall expect to find more or less radical discontinuities between the two [social and cultural aspects]. I would argue that it is in these very discontinuities that we shall find some of the primary driving forces in change. (1973, p. 144)

The funeral rituals he analysed were incongruities between the cultural framework and the patterning of social interaction that can be explained in depth only by a dynamic theory which considers the divergences between the need to find significance and the need to maintain a functioning social organism. These incongruities are found, too, in the difficulties encountered in the transformation of a community. But they can also be looked upon as a guarantee that the community maintains its roots in the face of globalisation - understood here as a global system characterised by standardised processes.

On the other hand, it is very important to understand the factors that influence change, because situations are diverse. Joseph Stiglitz' (2002) analysis of modernisation processes in Asian countries and the role that the World Bank played in these processes leads us to consider the sequence and the rhythm of change. Stiglitz states that different situations generate different sequences and rhythms each country, situation and development process is different. Sequence may be defined as the development of events in relationship with both general and particular 
characteristics of the specific contexts. Rhythm would then be speed of change and the speed of modernisation processes. Therefore in different social and cultural settings sequence and rhythm must be different. Taking this as a starting point, it becomes important to recognize and encourage development processes that are compatible with the specific sequences and rhythms naturally present in communities. By the same token, some local development failures could be explained by the absence of such conditions.

So, it seems necessary to rethink the role of adult education and learning in community processes. We are not interested in adult education as a question of developing skills to read, write, make calculations and so on, or to simply acquire competences to become employable. Adult education and learning can in fact be understood as a real process to help people to read the world and change it, a more general skill that is so important in the life of individuals and communities. To be able to interpret social reality can make all the difference. So we will here briefly present three elements that we think are fundamental to making a difference, following Paulo Freire's work (1970, 1990): the collective/community, dialogue and transformation.

To propose any form of collective action today is to oppose the growing tide of individualism, both in our societies and in educational institutions. We know that individualism is directed toward competition and to the notions that individuals should have the ability to build up a pool of 'useful' knowledge and skills, which should be related directly to competition in the labour market, for instance. But turning from individual action, to social action in communities as a priority means opting for diversity and recognising the Other as an essential element in building a plural, multicultural society. It also means building collectively in communities, but starting from the second element, that is, starting from dialogue. These processes could be identified also as research projects. Participatory Research (PR) can be considered as a methodology to undertake this. Participation is a priority and is the distinctive element of this methodology.

Orlando Fals Borda, in 1997 - at a Conference in Cartagena de Indias, Colombia - advocated the use of PR as opposed to Action Research - or as he called it Participatory Action Research - emphasizing participation as the essence of this methodology (Fals, 1998). Participatory research provides a way to give people the power to take actions that further improvements in their lives and communities.

Next to the participatory element so distinctive of PR methodology is the concept of Vivencia, which Fals defines as "a complex of attitudes and values that can give meaning to our praxis in the field" (Fals, 2001, p. 31). Vivencia holds a double meaning. On the one hand, it allows people to give sense to the things that happen in their community: it is the symbolic universe drawn on by Geertz (1973) as a part of his semiotic concept of culture. On the other hand, Vivencia means that people who are living and are involved in the life of the community have the most intimate knowledge of it. Consequently, the creation of knowledge comes from people's daily life. As Tandon declares: 
[the] essence of the participatory research tradition was understanding the political economy of knowledge; its practice-linked inquiry and investigation of social reality with learning and education, on the one hand, and organizing and action, on the other. (Tandon, 2008, p. 5)

And, it can be added, that this can be achieved through dialogue. The dialogue is opposed to any form of reciprocal denial and it is therefore fundamental to recognising the Other and finding ways of working together.

Last but not least is the ability to read social reality as an essential step to change it. To Freire, the possibility that each person can say his or her word is by itself an act of creation that helps them to better understand reality. Without this capacity to position ourselves within the world we live in and understand the motives that are shaping social reality today, we cannot change the world through the actions triggered by the awareness we have gained.

\section{THE CHAPTERS AND THE AUTHORS}

The single chapters of this volume reflect the research in the field of adult education and learning in and with communities and at the same time, in a more intimate fashion, the work of the authors presented here offers a very vital reflection of the work of the still young research network Between Global and Local - Adult Learning and Development which meets and discusses under the friendly roof of the European Society for the Research on the Education of Adults (ESREA). All of the authors have contributed to the work of the network since its formation at the University of the Algarve in Faro, Portugal in 2006. They represent with the chapters included in this book the important consensus of direction, purpose and conviction that characterises the activity of the network and its participants. At the same time, their individual work testifies to the broad range of professional practice, the variety in both methodology and theoretical background as well as to the impressive scope of field research experience they bring to bear in their chapters. This researcher experience out of which the book is made, is uncompromisingly grounded in knowledge of the field in a wide range of local contexts of adult learning as well as of the social movements that have arisen to pursue the aims of social justice and equality that have galvanised individuals and communities to access new forms of knowledge, acquire new types of social capital and change the life worlds of communities. From Scotland, Belgium, and Switzerland, in Anatolia, Poland, Spain and Portugal, to Mexico and Canada.

\section{Section I: The Bigger Picture}

In the opening chapter, Budd Hall (Towards a knowledge democracy movement) draws a broad picture of the development of international research and practice into community development and critical social knowledge creation through adult 
education. Hall reviews research on the impacts of inequality (Wilkinson \& Pickett, 2009), discourses and trends in HE such as engaged scholarship (Boyer, 2006), community based research (Strand et al., 2009), civic engagement, knowledge mobilisation and knowledge impact (Levesque, 2008) and their resonances and contact with transformative pedagogies inspired by Freire. These pedagogies include: participatory research, action research, and participatory action research. $\mathrm{He}$ argues that recognizing alternative sites of knowledge construction such as social movements, community organizations, the excluded themselves, including also indigenous forms of knowing, can help to create a global knowledge movement.

Emilio Lucio-Villegas and António Fragoso (A tramp shining) discuss the role of the educator. They begin by defining community as common identity (Williams, 1989; Hoggart, 1966) and community as a place of conflict (Wildemeersch \& Vandenabeele, 2007). The model of local development they propose involves the concept of deliberative democracy, and the role of the educator/expert/ organic intellectual (Gramsci) is founded on mediation and social change. The Freirian perspective the authors adopt sees educators as starting from people's real situations (e.g. the example of an amateur fishing club in Portugal). They see adult education taking place in non-formal processes of learning in grass-roots social networks and with the aid of the local anglers' experiences show how people are building collectively narratives of citizenship and participation that are rooted in their daily practices in the community.

The third chapter is from Rozalia Ligus (Symbolic closing of local community and reflexivity). Employing Lyn Tett's three main areas of meaning - place, interest and function - given to communities by their members (Tett, 2010), Ligus analyzes from a biographical and sociological perspective the process of the closing of symbolic spaces as observed in the case of certain local communities in Poland which have experienced what she terms a 'broken' historical continuity. In so doing, Ligus introduces a valuable review of selected Polish work on adult learning and communities. Her findings confirm that each community follows its own path of development and that the character of that development is dependent on numerous 'soft' factors, among which the competence of reflexivity seems to be a key concept. The people of the three local communities she studies, who are located in close proximity to one another, have nevertheless very different attitudes toward their local development and towards opening up new learning spaces. Their attitudes to the local space depend on locally constructed meanings given to the community which can be the result of different biographical experiences.

The chapter written by Anna Bilon and Ewa Kurantowicz (The results of local community projects - political and research contexts), which closes the first section of the book, further highlights contradictions in the development of community learning. In fact, Bilon \& Kurantowicz argue that Polish local communities, in a similar way to communities in other countries, are directly subjected to the imperatives: "what is local?" and "what is global?" The result is that local communities find themselves situated 'between' global socio-cultural and economic processes and local social and 
socio-economic circumstances. Consequently, local communities which constitute peripheries within their own country face particularly tough conditions in striving for an inclusive and balanced development in the face of national and international pressures. In this light, Bilon and Kurantowicz point out difficulties that accompany attempts to evaluate the effectiveness of various forms of support for individuals and local communities, especially those which focus on labour market re-entry action plans in general without considering local factors, such as local labour market specifics. Employing interviews with individuals involved in the implementation of such labour market re-entry plans and other support projects for the members of local communities, the authors indicate the need for participatory models of community learning, a recognition of community experience and knowledge and encouragment of civic participation and engagement.

\section{Section II: Adult Learning and Communities}

The second section of the book presents a range of chapters from Scotland, Switzerland, Poland, Portugal, Belgium and Turkey which all in related ways touch on educators/mediators who work in local and regional contexts in which the tensions of the wider policy and discourse environment impact on adult learners: migrants, regional populations, ethnic 'minorities' and the socially marginalised.

This section begins with Pyollim Hong and Jim Crowther's chapter (Learning citizenship in the community). Hong and Crowther consider young adults' experiences of learning citizenship in the community in Scotland. Their starting point is that democracy is contested and what is practised in its name needs to be engaged with critically. The authors focus on how community, participation and citizenship are constructed in ways which emphasise social and political capital and that, increasingly, learning citizenship is shaped very much by a neoliberal version of citizenship (and democracy) which serves to encourage a depoliticised and individualised version of citizenship rather than one that is concerned with the collective needs and interests of the wider community and society. Through their discussion of young adults' experiences of the struggle for employment, they indicate the importance of spaces which encourage young adults' participation in the community as an opportunity to explore issues and concerns that allow them to think and act individually and collectively (i.e., as political agents).

In Chris Parson's contribution (Adult literacy and empowerment - Learning for freedom) participatory educator/learner experiences in a Swiss literacy NGO are discussed, raising critical questions about the increasing prevalence of deficit models of learning and social identity. The seeds of a Freirian approach were sown in the literacy project discussed by Parson with the inclusion in the project goals of the term "mutualisation", and the proposition to use Reflect-Action as the first methodological approach to be shared. Reflect-Action proposes a methodology, or rather a process whose aim is to foster participation in democratic life, to encourage taking up and expressing one's position, improving communication skills, analysing 
and sharing power. Its principles are consistent with those of lifelong learning, or at least as expressed in discourse on LLL. It can be used with groups of adult learners or in any group setting where transformation is one of the goals. It allows the group to establish its own analytical and working framework by means of the participation and engagement of all the members of the group. Thus, a manifesto of adult learning could be developed that asked that voices of adult learners be heard when they speak of their experiences, hopes and plans for the future, frustrations and pain in the present.

Adrianna Nizińska: (Social capital, adult learning and equality) examines the discourses of social capital and equality (Arrow, 2000; Oyen, 2002) that shape our understandings of individual and group participation in learning processes. Pointing out that the value of social capital depends on its place in the social order, she argues that the poor and the marginalised rely on networks built upon survival strategies in which social bonding capital comes very much to the fore. Such bonding capital serves to reduce the effects of natural and macro-economic shocks, a phenomenon growing in significance in the post-financial crisis EU and beyond. Nizińska considers the potential of an increase in social capital - for example through access to education for the marginalised but equally, and perhaps more crucially, through education of those enjoying greater social capital and in possession of access to social networks promoting inclusion and citizen participation to raise understanding of the problems of marginalisation and exclusion generally. From this she seeks to draw conclusions about the forms of solidarity, mechanical or organic according to Durkheim's classical formulation, in local communities affected by exogenous shocks, that may be developed.

Isabel Gomes and Alcides Monteiro in their chapter (Why choose one hand over the other when we can use the best of two?) ask what the contribution of educators is in programmes ostensibly offering adult learners new learning opportunities? They highlight the dichotomies existing in research practice and pedagogy between normative, internalised forms of knowledge acquisition and the alternative of community-based, social and cultural learning. Employing Lima's notion (2007) of the 'multiform' nature of lifelong learning, the authors stress the importance of change and conflict in community learning processes and propose new functions for the educator as facilitator and mediator in this process. Embracing Lima's idea means developing a comprehensive understanding of adult learning which includes both sides of currently discussed education policies and proposals: the 'right hand' representing the most pragmatic, functional and purely adaptive education, and the 'left hand' expressing the critical, developmental and radical approaches. The authors conclude by asking out loud whether adult education can actually survive the scarcity of critical adult educators who are able to use the best of both 'hands of lifelong education'?

Paul de Roo (Developing minority communities against the background of the 'necessary dream' of returning to the homeland) describes a Bilingual and Bicultural Education Program in Brussels which aims to provide children of immigrants with 
both the linguistic knowledge of the place of residence as well as the language of their parents' original 'home'. The author highlights the contradictions lived by immigrant parents and children caught between conflicting cultural, geographical and economic pressures. The chapter explores the complexity of language as a creator and projector of identity, and illustrates how language identity serves both real, market-led interests, as well as, and more importantly, the interests of community identity construction.

Finishing off the second section of the book, Özlem Ünlühisarcıklı (Adult literacy participants in Turkey) draws a balance of the work of adult literacy work in Istanbul. The author conducted narrative interviews with women attending literacy courses in the 'Mother-Daughter Together in School' literacy campaign. The narratives of the women were analysed thematically, coded and subjected to cross-case analysis. The analysis demonstrates the connections between education opportunities, social networks, gender and experiences of migration. In fact, all the women involved in the research the author reports, found access to literacy education only in their place of residence as migrants from rural areas or smaller cities in Turkey and only after their traditional roles as family-makers and mothers allowed them to access learning. Ünlühisarcıklı demonstrates that attending the adult literacy course not only provided the women in question with literacy skills but also provided opportunities for social interaction. The important outcomes for these adult learners included a marked growth in self-confidence, a challenge to their lives in isolation and awareness of the importance of education for girls.

\section{Section III: Learning in Social Movements and Local Change - Research at Close Quarters}

This third section presents fieldwork from as varied sites as Chiapas in Mexico, to the North-East Algarve in Portugal, Scotland to Turkey. All these studies represent slices of experience of learning processes inside social movements, which are understood as emancipatory movements. The construction of identity is central in these moments of group and community learning.

The chapters also study the transformative effects of community development through training and qualification programmes that open up spaces for empowerment and local agency. These case studies portray in convincing fashion the mixed impacts felt when adult learners achieve new levels of personal agency, the effects of gender emancipation and of economic independence when they begin to emerge in traditional social environments. All of these chapters reflect, too, the power of research conducted in communities to uncover narratives of empathy and solidarity, of hope and sometimes, too, of failure. The research process remains open and, as the story of the women of Cachopo shows (see Fragoso \& Ollagnier), the longterm impacts of learning in communities, while often rich in disappointments, are unpredictable and always surprising.

António Fragoso and Edmée Ollagnier (The involvement of women in training as a step towards an emancipatory community development process) describe the 
development of projects to offer educational opportunities to women in the NorthEastern Algarve and draw out the results in situ over time as the conflicting forces of transformation through learning are confronted by the forces of local community tradition as well as the impacts of regional and supra-regional economic realities. The authors point out how training programmes imply a re-organisation of women's lives and indicate the impact of the rationales of existing gender roles. Rendering women's work visible and recognised as work and cementing the achievement of women's social networks opens up the possibility, in Freirian terms, of accessing power and knowledge in the community.

Lyn Tett (Researching and sharing power with a learning community) discusses power and agency, power and learning in the creation of learning communities. Power is shown to be omnipresent, whether used or shared, imposed from without or regulated from within in the form of surveillance or supervision. The relationships between learners and educators/mediators are discussed as taking place under the influence of forms of power that can be seen as power over participants, power with them, or power within, i.e., the experience of empowerment in practice as a result of creating a learning community of adults. Tett's conclusion is of enormous practical importance to all involved in the hard task of building and sharing power in learning contexts: it is no easy task. While being able to construct and use power-from-within towards common goals can be a transformative process, Tett insists on the need to recognise the many challenges that must be overcome before this participative process can be realised. Different knowledges must be valued, understandings shared and risks taken.

Joaquim do Arco (Adult education for social transformation in a locality of the Northeastern Algarve) in a contribution that echoes many of the learning experiences illustrated by Fragoso \& Ollagnier, by Pilch Ortega and, finally, in Seçkin, draws out the importance of the role of the educator as initiator and point of reference for adult learners when accessing social learning programmes such as those described in this chapter by do Arco. The stories educators shared and re-built with the community allow us to imagine a new and desirable future, in the terms and conditions shaped by the community, a kind of local development based on popular education that allows people and communities to be the central collective actor. Arco argues that these types of territorial approaches to development are in rapid disappearance today, making it all the more urgent that we recall stories that bring forth what used to be a valuable dimension of adult education. He argues likewise that we should see the importance of literacy processes which were, really, the departure point of the global educational processes that went on in the period he analyzes. The transformative action of educators remains, in short, a matter of joining literacy with citizenship, something that has been a necessary link in the past and just as certainly remains so in the present and in the future.

Angela Pilch Ortega (Learning and local change in social movements in Chiapas, Mexico) in her study of learning processes inside social movements in the region of Chiapas in Mexico underlines the emancipatory function of learning. Through 
community learning, adults can overcome the invisible structuring of discriminated ethnic identity. The author argues for the importance of new needs arising in regional communities as a result of their inclusion in globalizing processes. A result of this changing situation is that new public spheres, new spaces for action arise with new ways of communicating needs and interests. The author's biographical method seeks to render visible through the adults' biographies of marginalization the workings of regional, national and transnational hegemonic forces. Articulation of community needs and empowered identities allow the Chiapas populations to question inequalities in their social situation and pose demands for access to health, education and ethnic/gender rights.

Onur Seçkin (Social movements and adult learning: A story of women in a local environmental movement in Turkey) in this final chapter offers a study of the transforming effect of participation in learning processes that speak directly to the local needs of communities facing the pressures of neo-liberal reforms, of environmental threats and economic discrimination in remote rural communities. Seçkin argues that social movements are engines of change in the context of resistance to neoliberal policies and can generate alternatives. At the same time, social movements are important learning sites for adults, where adults learn that they can change things if they struggle. While learning experiences in social movements are important for the success of the movements, such experiences provide critical dimensions, too, of adult education for the adults. Adults learn, Seçkin claims, for their vital needs in social movements, a long cry from the economistic-based perceptions of adult learning that are so current in our globalized world. In this chapter, through the story of Ayşe, a woman activist in the Kaz Mountains Environmental Social Movement, Seçkin shows how and what adults learn in action and how their lives change with their learning experiences.

\section{CONCLUSIONS}

This book is rich in both reflections and actions on how to research and transform communities in the fields of adult learning and education. If the first section of the book is devoted to presenting a more general reflection, the other two sections, as we have seen, present experiences from this kind of work - linking development, social change and education - around Europe and beyond. In this selection of research fields and methodological perspectives, the first thing that can be stressed in this book is diversity, which is wholly coherent with the diversity we face when talking about communities. As Ligus (in this volume) states, it is possible to differentiate between several forms of community. These diverse communities include within themselves all the diversity of the people living in them. For a long time community was considered a homogeneous, container-type space that differentiated neatly between 'us' and 'them' (Hoggart, 1966). This kind of symbolic shelter to people, however, hides a reality: community is a place where conflict and confrontation are the usual thing, and, we add, conflict and the way conflict is resolved are substantial 
elements in the definition of community as a symbolic place (Kurantowicz, 2008). Thus, our first conclusion is an invitation to reflect on the 'squeezed' and 'crowded' concept of community and the different roles that it can play in people's daily lives, either as a place of shelter or as a place of confrontation and debate.

But community is also a place in which to join people. As Biesta (2014) makes clear, it is a public place where everyday life is developed. In this sense, it can be affirmed that community is a place to learn. To learn about democracy and participation, as Pyollim and Crowther (in this volume) reflect, focusing on a specific case related to young people. But we can also add that community is, beyond a place to learn, the source for learning and teaching. In a Freirean way we can consider that the generative themes come from the surrounding environment. In this sense it is possible to consider the knowledge creation inside the community (see Hall in this volume). Community is a place where people are creating knowledge about the community and about themselves. The educative process can lead to the knowledge created becoming 'really useful knowledge' to transform communities and improve the life of the people living in them. As Gaventa and Cornwall (2001) write:

The emphasis is more upon the ways in which production of knowledge shapes consciousness of the agenda in first place, and participation in knowledge production becomes a method for building greater awareness and more authentic self-consciousness of one's issues and capacities for action. (p. 71)

So, the creation of knowledge seems to be an important step to researching and transforming communities, but this creation of knowledge should be done in an alternative way - as Participatory Research does - and produce an alternative knowledge: a liberating knowledge that allows people to understand and transform the surrounding environment.

For this, it is important to carry out research in the learning processes that take place in communities. Education and literacy are substantial elements in this process. Ünlühisarccklı (in this volume) reflects on the larger importance of literacy campaigns and the power of literacy to help people to understand the world. These educative processes are also present in the work of Fragoso and Ollagnier and Arco (in this volume) when talking about the development of community projects in deprived areas and how these projects had an important impact in building up new gender relations, but also help us to reflect about the resources that can be understood as helping to construct local productive activities. Communities seem to be privileged spaces in which to organise those specific productive processes that enable people to keep on living in their hometowns - as Bruce Springsteen sang and with a minimum of quality of life and welfare. In the end, craftsmen are people that have to be recognised for their contribution to the community (Sennett, 2010). It can be said that these activities are doors and openings into thinking about other spaces where adult education takes place.

Social Movements can be considered as new agents of adult education and development. Seçkin (in this volume) links the problematic of two of the so-called 
new social movements, the women's movement and the environmental movement, to tell us stories of fighting, resistance, and learning. In this sense it is possible to conclude that social movements are also creators of solidarity, and communities are based on the solidarity among their members, but also on solidarity with other people outside the community. This means to move from 'I' to 'we' as Sennett (2000) suggested.

In short, we conclude that the most important task is to reflect on social change and how adult education and learning help people to produce these changes - which become emancipation - in a participatory and democratic way.

\section{REFERENCES}

Arrow, K. (2000). Observations on social capital. In P. Dasgupta \& I. Serageldin (Eds.), Social capital: A multifaceted analysis. Washington, DC: The World Bank.

Biesta, G. (2014). The beautiful risk of education. London, England: Paradigm Publishers.

Boyer, E. L. (2006). The scholarship of engagement. Journal of Public Service and Outreach, 1(1), 11-20.

Fals Borda, O. (Ed.). (1998). People's participation: Challenges ahead. New York, NY \& London, England: Apex Press.

Fals Borda, O. (2001). Participatory (action) research in social theory: Origins and challenges. In P. Reason \& H. Bradbury (Eds.), Handbook of action research: Participative enquiry and practice. London, England: Sage Publications.

Freire, P. (1970). Pedagogy of the oppressed. New York, NY: The Continuum Publishing Company.

Freire, P. (1990). La Naturaleza Política de la Educación. Barcelona, Spain: Paidós.

Gaventa, J., \& Cornwall, A. (2001). Power and knowledge. In P. Reason \& H. Bradbury (Eds.), Handbook of action research: Participative enquiry and practice. London, England: Sage Publications.

Geertz, C. (1973). The interpretation of cultures. New York, NY: Basic Books.

Hoggart, R. (1966). The uses of literacy. London, England: Pelican.

Kurantowicz, E. (2008). Community learning. Resources, actions and reflexivity of territorial communities. In A. Fragoso, E. Kurantowicz, \& E. Lucio-Villegas (Eds.), Local in global: Adult learning and community development (Proceedings of the ESREA Between Global and Local Research Network Conference, Wrocław, 2008). Wrocław, Poland: Wydawnictwo Naukowe.

Levesque, P. (2008). Government support and infrastructure: Realizing the value of collaborative work. Gateways: International Journal of Community Research and Engagement, 1(2008), 150-164.

Lima, L. C. (2007). Educação ao longo da vida: Entre a mão direita e a mão esquerda de Miró. São Paulo, Brazil: Cortez.

Oyen, E. (2002). Social capital formation: A poverty reducing strategy? In Social capital and poverty reduction: Which role for the civil society organizations and the state? (pp. 11-14). Geneva, Switzerland: UNESCO and CROP.

Sennett, R. (2000). La corrosion del carácter. Madrid, Spain: Anagrama.

Sennett, R. (2010). El respeto. Madrid, Spain: Anagrama.

Stigliz, J. (2002). El malestar en la globalización. Madrid, Spain: Taurus.

Strand, K., Marullo, S., Cutforth, N., Stoecker, R., \& Donohue, P. (2003). Principles of best practice for community-based research. Michigan Journal of Community Service Learning, 9(3), 5-15.

Tandon, R. (2008). Participation, citizenship and democracy: Reflections on 25 years of PRIA. Community Development Journal, 43(3), 284-296.

Tett, L. (2010). Community education, learning and development (3rd ed.). Edinburgh, Scotland: Dunedin Academic Press.

Wildemeersch, D., \& Vandenabeele, J. (2007). Relocating social learning as a democratic practice. In R. van der Veen, D. Wildemeersch, J. Youngblood, \& V. Marsick (Eds.), Democratic practices as learning opportunities. Rotterdam, The Netherlands: Sense Publishers. 


\section{R. EVANS ET AL.}

Williams, R. (1960). Border country. London, England: Parthian Books.

Williams, R. (1985). Keywords. London, England: Fontana.

Wilkinson, R., \& Pickett, K. (2009). The spirit level: Why more equal societies almost always do better. London, England: Alan Lane.

\section{Rob Evans}

University of Magdeburg, Germany

\section{Ewa Kurantowicz}

University of Lower Silesia, Poland

\section{Emilio Lucio-Villegas}

University of Seville, Spain 


\section{SECTION I}

THE BIGGER PICTURE 



\author{
BUDD L. HALL
}

\title{
2. TOWARDS A KNOWLEDGE DEMOCRACY MOVEMENT
}

\section{BACKGROUND}

In the city where I live, Victoria, Canada, a wealthy city in a wealthy country, there are 1500 women and men (in a population of 250,000) who do not have a place to sleep at night. In spite of the creation of the Coalition Against Homelessness, the numbers of people who suffer from poor health, violence, substance abuse as a result of poverty and homelessness continues at about the same level. In India one of the fastest growing economies in the world, 600 million people live without literacy, adequate water and sanitation, poor health facilities and insecure food security. Indigenous people in North and South America, Africa and Asia have dramatically lower life expectancy and higher levels of health difficulties than the non-indigenous members of their communities. Their languages are disappearing daily and with the languages, extraordinary parts of our human knowledge base and culture. Climate change is having a more dramatic impact on the poor and marginalized persons in all our communities; one only has to look at the earthquake in Haiti or the floods in Pakistan to see how natural disasters impact the poor. The neo-liberal global economic machine produces wealth in historically unheard of quantities but exacerbates the gap between the rich and the poor both within nations and amongst nations.

These situations exist in spite of bodies of recent quality research on the impacts of inequality in our lives at both local and global levels. According to Wilkinson and Pickett, on almost every index of quality of life, or wellness, or deprivation, there is a strong correlation between a country's level of economic equality and its social outcomes. Almost always, Japan and the Scandinavian countries with less disparity between the rich and the poor have more positive social and health outcomes. The UK, the US and Portugal, which have high disparities between the rich, and the poor have poor results. What is so powerful in their research is evidence that both the rich and the poor fare better in societies with less inequality (Wilkinson \& Pickett, 2009).

\section{INTRODUCTION}

This chapter explores some of the discourses and trends in Higher Education Institutions expressed by such concepts such as engaged scholarship (Boyer, 2006), community-based research (Strand et al., 2003), community-university research 
partnerships (Hall, 2009; Hart et al., 2007), community-university engagement (Watson, 2006), civic engagement (University of Victoria strategic plan), or knowledge mobilization and knowledge impact (Levesque, 2008). What are the driving forces behind or within these trends? What kinds of structures and networks are emerging to support this work? What are the opportunities and dangers implied? Can these structures support the traditions of libratory and transformative pedagogies and practices inspired by Freire and the early work done in participatory research? How do these trends relate to the broad contemporary discourses of action research or participatory action research? Does the space that is opening within Universities provide an opportunity to recognize alternative sites of knowledge construction such as social movements, community organizations, the poor, homeless, and the excluded themselves? Does the focus on knowledge examine the contributions of broader ways of knowing such as Indigenous Forms of Knowing? Is there a possibility of a global knowledge movement? If so what would have to happen? In this piece, I focus on the dimensions of the higher education and engagement trends worldwide with a particular focus on research partnership and knowledge exchange developments, some of the dimensions of the community-based research movement within Canada, a look at the University of Victoria's Office for Community-Based Research and some thoughts on the potential emergence of a global knowledge movement.

\section{A KNOWLEDGE DEMOCRACY MOVEMENT?}

John Gaventa, a theoretician on power and citizenship, a pioneering participatory research leader, former Chair of Oxfam UK and currently Director of the Coady International Institute in Canada, was the first person in my experience to speak of social movements using a 'knowledge strategy' as their core political organising strategy (Gaventa \& Cornwall, 2008). His early work at Highlander Research and Education Centre in Appalachian Mountain region of the United States involved among other things the support of citizen researchers to go to local courthouses to find out the ownership of local coalmines. Absentee landlords owned all of the mines in question from as far away as New York or London. And while profits were good, taxes were very low for these absentee landlords so that resources were not sufficient to cover the costs of good schools, health services or other social services to allow the mine workers and their families to flourish. These citizen researchers using what John called a "knowledge strategy" for organizing, pooled their knowledge across six or seven Appalachian states and produced an important study on mine ownership, which had an impact on changing tax structures in some of the states in question. Highlander and Gaventa were later to move into a campaign for environmental justice using many of the same principles (Cable \& Benson, 1993).

How can we understand a concept like a knowledge democracy movement? First I am working on an assumption that social movements remain at the heart of local and global change; that they are critically important sources of power to shift the way that people imagine various relations of power. With that argument 
I am building on the very long tradition of learning and social movement theory and practice including much that I have written about in earlier forms (Hall, 2009). I am not referring to engaged scholarship or $\mathrm{HE}$ and community engagement itself as a movement, although there are movement elements to the ways in which community university partnerships are expanding. I am also not using other words to speak about the 'knowledge economy.' The knowledge economy specifically links knowledge production of certain types and skill development in certain ranges of skill development to global capitalist production and distribution mediated often through the digital technologies.

A 'knowledge democracy movement' is an action-oriented formation that recognizes, gives visibility to and strengthens the knowledge that is created in the context of, as Marx said, people trying to 'change the world'. A knowledge democracy movement recognizes, values and supports the recovery and deepening of indigenous ways of knowing (Wangoola, 2000; Williams \& Tanaka, 2009). A global knowledge movement recognizes the epistemic privilege of the homeless themselves as a key to taking in action on issues of homelessness. It would celebrate the intellectual contributions of young people who are differently abled. It would honour the early work of Engels gathering the insights of workers in the 19th century factories of Manchester, England or Marx's work in the Moselle river valley of Germany learning from workers in the vineyards. It would recognize that the Gay and Lesbian movement and the HIV/AIDS movements have been built fundamentally on the knowledge of Gay and Lesbian citizens themselves.

A knowledge movement or a movement that uses knowledge as a key mobilising and organising strategy is centred within the lives and places of those who are seeking recognition of their rights, their land claims, access to jobs, ecological justice, recovery or retention of their languages. Knowledge itself within such a movement formation is most likely place-based and rooted in the daily lives of people who increase their knowledge of their own contexts and by sharing what they are learning with allies and others like themselves move, as Paulo Freire says, towards being agents in the naming of the world. The proliferation of discourse and practices within the world of community-university knowledge partnerships, in this conceptualisation, would be contributors to the broader knowledge movement. The extensive and important access to information developments would also be supportive of and a contributor towards a variety of knowledge movements, but neither the access to information developments nor the community-university engagement advancements form a global knowledge movement by themselves, but would be part of the necessary conditions for knowledge movements to gain footholds and flourish.

Knowledge Democracy from my perspectives therefore consists of at least three characteristics. First it means the recognition of multiple epistemologies and ways of knowing. A spirit of de-colonising knowledge and inclusion of knowledge systems beyond the Euro-centric western canon inform it. Second, knowledge democracy means recognition of multiple ways of representing knowledge. So while text, graphics, numbers and such continue to be important ways of communicating 
knowledge claims, we also look to music, theatre, art, poetry, ceremony, canoe carving and the myriad ways that knowledge is expressed. Finally we acknowledge as noted above that a knowledge strategy is an important if not essential dimension of social movement actions.

\section{Contestation for Influence within Higher Education}

Community-university engagement is one of the strongest trends cutting across our university campuses these days. There has been a veritable explosion of writing on community-university engagement over the past five to six years. Ernest Boyer laid down the conceptual foundations with his development of the concept of "engaged scholarship" (1996). The Kellogg Commission on the Future of State and Land-Grant Universities (Kellogg Commission, 1999) shifted the terms research, teaching and serve to the words discovery, learning and engagement. Susan Ostrander from Tufts University did a study of civil engagement on five campuses in the United States during 2001, which resulted in the articulation of a number of necessary components for effective engagement (Ostrander, 2004). David Watson former Vice-Chancellor of Brighton University initiated a robust Community-University Partnership Programme (CUPP) at his university, but in addition is an eloquent spokesperson for the links between lifelong learning, communities and university engagement (Watson, 2007; Watson \& Maddison, 2005; Watson, 2008; Watson, 2009). Angie Hart, current academic director of CUPP has added much to our understanding of how community engagement works and some useful ideas about how to evaluate the impact of this work (Hart, Maddison, \& Wolff, 2007; Hart, Northmore, \& Gerhardt, 2007). Barbara Holland and Judith Ramaley of University of Western Sidney and Winnona State University respectively have reviewed community engagement approaches in the UK, Spain, Germany, India, Japan, Vietnam, Thailand, Philippines, Australia, USA, Canada, Mexico, Argentina, Brazil and South Africa and have created a typology of how Universities approach the change associated with the community-university change agenda. They identify the planning, leadership, engagement strategies, accountability frameworks and more of institutions taking routine, strategic or transformative approaches to the engagement process (Holland \& Ramaley, 2008). Lorraine McIlrath and Iain Mac Labhrainn of the National University of Ireland, Galway and leaders of the Community Knowledge Initiative have pulled together a very useful collection of papers of international perspectives on Higher Education and Civic Engagement (McIlrath \& Iain Mac Labhrainn, 2007).

There are so many examples of recently created community university structures in other parts of the world. Spain for example has seen the Instituto Paulo Freire; a national community-university research network has its organizational base in several Spanish Universities including Valencia, Gerona and Sevilla (www.institutpaulofreire.org). CREA, the Centre for theories and practice in Overcoming Inequalities, was one of the sources of inspiration for the University of Victoria when it started its Office of Community-Based Research. Professor 
Emilio Lucio-Villegas was the founding holder of the Cátedra Paulo Freire at the Universidad de Sevilla. The Cátedra located within the Faculty of Education, was a hub for community-university participatory research throughout the region.

Not all of the structures or organizations that facilitate the creation of communityuniversity partnerships are located within universities. It is critically important to note that much of the early history of community-based research, participatory research and similar approaches originated within and/or were supported by civil society organisation. If we look at the Science Shop Movement in Europe for example one will find a majority of the Science Shops are based in Universities, but not all. The Bonn Science Shop is a cooperative non-governmental organisation that had its origins in a university, but found that it had much more freedom for progressive research and social action when located as an independent community organisation. It works never the less as do other Science Shops, linking university students and researchers with community activists and organisations that need research to be done.

The Society for Participatory Research in Asia (PRIA) based in New Delhi, India is nearing 30 years of operations. Its motto is 'knowledge is power'. It is legally structured as a non-governmental civil society organisation. PRIA carries out research with communities of excluded and oppressed people. It provides capacitybuilding workshops and training opportunities for local government workers and grass roots NGO workers in participatory research and evaluation. It works on issues of citizenship and governance, on health and safety in the workplace, on sustainability and local economic development and in local planning. Because of its long-term skills and reputation for ethical and democratic research approaches, universities in India have sought PRIA out to provide teaching and field placement opportunities for students who are going in to work in rural areas, in fields of social work or as community-based researchers. They broker community-university research partnerships but from the community side of things.

In Canada, the Community Based Research Centre was established nearly 25 years ago as a local non-governmental organization. It has grown over the years to have a staff of 25-30 persons working on behalf of community organisations to serve their research and evaluation needs. They work on issues of anti-racism and multicultural health, employment and cultural issues. They draw on the resources of several universities in the Waterloo region of Ontario (about $11 / 2$ hours west of Toronto). In May of 2011 they hosted the 4th Community University Exposition (CuExpo, 2011) a national and international space for community and university partners to meet to share with others (www.cuexpo2011.ca).

\section{CANADIAN DEVELOPMENTS}

In Canada, Edward Jackson at Carleton University has conceptualized what he calls the "CUE (Community-University Engagement) Factor". He writes of the dynamic triangle of community-university engagement being, community-based experiential 
learning, community-based research and community-based continuing education. He calls on universities across Canada to, "increase their CUE factors by deepening and broadening their teaching, research and volunteering activities with the external constituencies that have the greatest need for sustainable solutions to the challenges they face every day" (Jackson).

One of the three legs of Jackson's CUE Factor, community-based research (CBR), has a particularly strong Canadian history and specificity. In the mid-1970s a group of researchers based in Toronto and associated with the Ontario Institute for Studies in Education and the International Council for Adult Education created a group called the participatory research project. Hall, Jackson, Marino, Barndt, Conchelos and others had a variety of community-based research experiences in Canada and other parts of the world. They were supported by the late Drs. J. Roby Kidd and James Draper who were Professors in the Adult Education Department at OISE and in the case of Dr. Kidd, the Secretary-General of the newly launched International Council for Adult Education (Hall, 2005).

Inspired in part by Canada's early work in participatory and community-based research and by the experience of the Science Shops in the Netherlands, the Social Sciences and Humanities Research Council created the SSHRC-Community University Research Alliance (CURA) funding structure. The CURA model has become known widely throughout the world and has resulted in rise of a unique meeting space called the Community-University Expositions (CUexpos) which have now taken place in Saskatoon in 2003, Winnipeg in 2005, Victoria in 2008, and Newfoundland in 2013. Out of this combined energy has come the recently created Community-Based Research Canada (CBRC) and the Global Alliance for Community-Engaged Research (http://www.uvic.ca/ocbr). Within our universities, CBR has begun to become institutionalized. The University of Victoria in January of 2007 created the Office of Community-Based Research as a university-wide structure reporting to the Vice-President of Research. This has recently been enhanced and renamed as the Institute for Studies and Innovation in Community University Engagement. The Harris Centre at Memorial University in Newfoundland serves a similar function throughout Newfoundland and Labrador (Fitzpatrick, 2008). The Trent Centre for Community Education, the Institute for CBR at Vancouver Island University, the Community University Partnership Programme at the University of Alberta, the Centre for Community-Based Research in Kitchener, the Centre for Community Research, Learning and Action at Wilfred-Laurier University in Waterloo, the Services aux Collectivités at the Université de Québec à Montréal and others have sprung up across the country.

\section{THE OFFICE OF COMMUNITY-BASED RESEARCH AT THE UNIVERSITY OF VICTORIA}

The Office of Community-Based Research at the University of Victoria was created to facilitate collaborative community-university research partnerships that 
enhance the quality of life and the economic, environmental and social well being of communities. It was located administratively within the office of the Vice-President, Research and has a Steering Committee that was co-chaired by the Vice-President, Research and the CEO of the United Way of Greater Victoria. The OCBR was a small unit with a part-time Director who was a senior academic, a part-time Associate Director with a community organising background and a full-time administrative coordinator.

The work that the OCBR gave the most attention to during its first years of activity include linking researchers, activists and policy makers engaged in issues such as homelessness and housing affordability, local food production and distribution, Indigenous language revitalization, health and adult learning needs. The OCBR had a regular series highlighting Indigenous Research Methods with community researchers as key. It also worked with instructors at the University of Victoria to facilitate sharing of how best to teach community based research in the undergraduate and graduate levels. The reflections of this two year series of conversations about how best to teach community based research has recently resulted in a book, the product of 36 university and community based scholar activists (Etmanski et al., 2013).

\section{THE VANCOUVER ISLAND COMMUNITY RESEARCH ALLIANCE (VICRA)}

VICRA is an alliance of the five post-secondary educational institutions located on Vancouver Island. They are united via a Memorandum of Understanding (MOU) signed by the respective President's of each of the five institutions. The five campuses include: The University of Victoria, Royal Road's University, Vancouver Island University, Camosun College and North Island College. The MOU calls on the group to: (1) identify priority research issues with an island wide focus; (2) develop and implement a process to identify relevant and available knowledge, information, skills, and capacities both in the Parties and in communities; (3) identify and develop research partnerships and share information on best practices that can be shared with others; (4) promote the engagement of the Parties' students in action research projects identified by communities/community members; (5) build capacity for community-based research and evidence-based planning among the spectrum of organisations and agencies that work to address the needs of Vancouver Island residents and communities; (6) build on each other's experiences and expertise, drawing on lessons from local, national and global networks/projects.

During 2008 and 2009, VICRA worked with communities up and down the island to see what common issues there were that our VICRA team might be able to address. Three areas emerged from these consultations, Aboriginal Health disparities, and lack of affordable housing and concerns about the sustainability and security of our food sources. In June of 2010, with a grant from the Canadian Social Science and Humanities Research Council, our VICRA team began work on a Local 
Food Production and Distribution Action Plan, a project that we proposed calling "Bringing the Food Home". VICRA will support the development of five "Local Food Production and Distribution" tables in various parts of the Island. With student CBR research interns from each of our campuses and research support from a team of distinguished food policy researchers, business people, organic farmers, chefs, food distributors, local government folks and others will sit together to decide how to remove the obstacles to local food production and distribution. Actions envisaged are the creation of a venture capital pool for small-scale farm producers, new solutions to food inspection sites and regulations, support for farm markets, better links to food wholesalers, and more.

\section{GLOBAL ALLIANCE ON COMMUNITY-ENGAGED RESEARCH (GACER)}

At the Global level, the European-based Living Knowledge Network, the Society for Participatory Research in Asia and Community-Based Research Canada have come together with a number of other regional CBR networks to create the Global Alliance on Community Based Research (www.gacer.com). Civil society and nongovernmental research bodies such as the Canadian Community-Based Research Centre in Ontario, the Bonn Science Shop in Germany, the Centro Boliviano de Estudios Multidisciplinarios in Bolivia, the Society for Participatory Research in Asia and the Mpambo Afrikan Multiversity in Uganda are important examples of the kinds of organizations that are needed. GACER has initiated four key activities to date: a launch of the statement of principles; advocacy within the United Nations World Conference on Higher Education; a global study of the potential impact of community-university research partnerships on issues such as poverty and sustainability and the creation of a global communiqué on the role of community university research engagement as a strategic element in the development of higher education everywhere.

\section{CREATION OF THE UNESCO CHAIR IN COMMUNITY-BASED RESEARCH AND SOCIAL RESPONSIBILITY}

Further evidence of the spread of the knowledge democracy movement has been the creation of the UNESCO Chair. Following conversations between those responsible for higher education at UNESCO headquarters and GACER, a proposal was extended to create a UNESCO Chair to support building capacity in the Global South. The proposal made was for the University of Victoria and the Society for Participatory Research in Asia to appoint two joint chair holders. The Chair was launched in 2012 and 2013 with Rajesh Tandon as one co-chair and Budd Hall as the other. The structure of the chair was meant to represent both a North-South cooperation and a civil society-university collaboration. The first major achievement of the chair has been involvement with the Global University Network for Innovation in the 
organising of the Barcelona International Conference on Knowledge, Engagement and Social Change and the subsequent publication of the first global report on knowledge democracy, The World Report on Higher Education 5: Knowledge, Engagement and Higher Education Contributing to Social Change (GUNi, 2014).

\section{ELEMENTS OF A KNOWLEDGE DEMOCRACY MOVEMENT}

There is unmistakable evidence of two major institutional trends within the world of knowledge generation and use. The first is the emergence of the 'knowledge access movement'. These developments are driven in part by the professional worlds of information technology located within libraries and digital repositories and in part by the explosion of digital information technologies. The Public Knowledge project based at the Universities of British Columbia, Simon Fraser University and Stanford University is one such expression. The research and software development of the Public Knowledge Project, which provides software for open access globally accessible electronic journals, is focused on improving the scholarly quality of publishing processes. It also seeks to expand the realm of public education by improving social science's contribution to public knowledge, in the belief that such a contribution is critical to academic freedom, the public use of reason, and deliberative forms of democracy. Its research program is investigating the social, economic, and technical issues entailed in the use of online infrastructure and knowledge management strategies to improve both the scholarly quality and public accessibility and coherence of this body of knowledge in a sustainable and globally accessible form (http://pkp.sfu.ca).

The second is the emergence or re-emergence of new discourses, practices and structures for knowledge mobilization, engaged scholarship, community-based research, and community-university research partnerships as illustrated by the work being done in Canada and the specific case of the University of Victoria. These newer developments are part of a broader turn of attention by Higher Education institutions all over the world to the impact of their presence in the communities and regions where they are located. Community or Civic engagement is becoming a normal aspiration to be mentioned in the strategic plans of universities. VicePresidencies for Engagement, Offices of Community Outreach, Office of Community-Based Research, Knowledge Mobilization Units, CommunityUniversity Partnership Programmes are but a few of the ways that these approaches are being institutionalised.

The strongest tendency in both these knowledge democracy developments is to see as a central value, the dissemination and impact of scholarly, academic, scientific or expert knowledge. Research granting agencies want to make sure that the public investments being made in research produce tangible results for society. Most of the stakeholders, whether academic staff or students, university administrators, or research funders operate from the assumption that knowledge is produced by scholars in universities and research institutes and that the benefits of this knowledge 
production, as a point of public morality or public accountability needs to benefit society. And it is critically important to support and acknowledge the extraordinary value of fundamental science to our understandings the way the world works whether in fields of physics or medicine or engineering or environmental science. The purpose of this argument is not to argue against this role of science or this role of the university. But if we are to see the advancements of a global knowledge movement or increased support for knowledge strategies within social movements, there is a third dimension that is needed.

The third leg of a knowledge democracy movement if it is to emerge more strongly has to be recognition that critically important knowledge is created in different ways and in different locations. As Eyerman and Jamison have noted in their study of social movements social movements are formations that create what they call 'cognitive praxis' (1991). Peter Levine speaks of the creation of public knowledge “...The process of creating public knowledge as an additional good, because such work builds social capital, strengthens communities and gives people skills that they need for effective citizenship. If this is correct then we should aim to include as many people (and ways of knowing) in the collaborative creation of "free" or open access knowledge...ordinary people should be recognized as knowledge creators" (2007).

From a study of a biocultural approach to a Traditional Knowledge Commons established by 80 traditional healers living in the Mpumalanga province in South Africa we have the following, "Knowledge is an outcome of virtuous relationships with the land, the plants and the animals. It is not property to be bought and sold. It is simultaneously cultural and spiritual and its movement and application promotes a kind of virtuous cohesiveness."

The Honey Bee Network that originated in India and is designed to document and share indigenous theory and practice has spread to 75 countries. This knowledge movement builds on the metaphor of the honeybee that collects pollen without impoverishing the flowers, and connects flower to flower through pollination. The idea is that when we collect knowledge of people we should ensure that people don't become poorer after sharing their insights with us.

The gift giving cultures of the Western Canadian Indigenous peoples demonstrate that we grow and benefit an economy where wealth moves through our communities as a continuously flowing gift. Just as the objective of a gift economy is to increase value through the movement of wealth, the objective of a knowledge movement is to increase value and well-being through the continuous gifting of knowledge.

We will not realize a transformative knowledge movement either locally or on a global scale, until recognition of the knowledge generating spaces outside the academy are recognized, until non-university organizations are able to access research funding, until the research and knowledge mobilization capacities of local community organisations and social movements are strengthened and until a larger voice from the community, the movements or democratic society can be heard within the development of the many institutional forms of knowledge and engagement 
that are evolving, but I believe that a strong argument can be made that pathways towards a knowledge democracy movement are being made. I further believe that the theory and practice of the rich history of the education of adults in the contexts of citizenship, social movements, transformation, place and social contexts have much to contribute as well as much to draw from.

\section{REFERENCES}

Boyer, E. L. (2006). The scholarship of engagement. Journal of Public Service and Outreach, 1(1), 11-20.

Cable, S., \& Benson, M. (1993, November). Acting locally: Environmental injustice and the emergence of grass-roots environmental organizations. Social Problems, 40(4), 464-477.

Etmanski, C., Hall, B., \& Dawson, T. (2014). Learning and teaching community based research: Linking pedagogy to practise. Toronto, ON: University of Toronto Press.

Eyerman, A., \& Jamison, R. (1991). Social movements: A cognitive approach. Philadelphia, PA: Penn State.

Foray, D. (2006). Optimizing the use of knowledge. In B. Kahin \& D. Foray (Eds.), Advancing knowledge and the knowledge economy. Cambridge, MA: MIT Press.

Gaventa, J., \& Cornwall, A. (2008). Power and knowledge. In P. Reason \& H. Bradbury (Eds.), Handbook of action research participative enquiry and practice. London, England: Sage Publications.

GUNi. (2014). World report on higher education 5: Knowledge, engagement and higher education contributing to social change. London, England \& New York, NY: Palgrave McMillan.

Hall, B. (2005). In from the cold? Reflections on participatory research 1970-2005. Convergence, 38(1), $5-24$.

Hall, B. (2009a). Higher education, community engagement and the public good: Building the future of continuing education in Canada. Canadian Journal of University Continuing Education, 35(1), 11-23.

Hall, B. (2009b). To change the world: Adult learning and social movements. In P. Jarvis (Ed.), The Routledge international handbook of lifelong learning. London, England: Pergamon.

Hall, B. (2009c). A river of life: Learning and environmental social movements. Interface: A Journal for and about Social Movements, 1(1), 46-78.

Hall, B. (2009d, June/July). Lyrics of the dawn: Poetry and social movement in conducive. Retrieved from www.conducivemag.com

Hart, A., Maddison, E., \& Wolff, D. (2007). Community-university partnerships in practice. Leicester, England: National Institute for Adult and Continuing Education.

Hart, A., Northmore, S., \& Gerhardt, C. (2008). Auditing, benchmarking and evaluating university public engagement (Briefing paper). Brighton, England: Community-University Partnership Programme.

Holland, B., \& Ramalay, J. (2008). Creating a supportive environment for community-university engagement: Conceptual frameworks. Keynote address to the HERDSA Annual Conference, Rotorua, New Zealand.

Jackson, E. (2008). The CUE factor: Community-university engagement for social innovation in open source business resources, September 2008: Social innovation. Retrieved from http://www.osbr.ca

Kellogg Commission on the Future of State and Land-Grant Universities. (1999). Returning to our roots. Washington, DC: National Association of State Universities and Land-Grant Colleges.

Levesque, P. (2008). Government support and infrastructure: Realizing the value of collaborative work. Gateways: International Journal of Community Research and Engagement, 1, 150-164.

McIlrath, L., \& Mac Labhrainn, I. (Eds.). (2007). Higher education and civic engagement: International perspectives. Aldershot, Hampshire, England: Ashgate.

Ostrander, S. A. (2004). Democracy, civic participation, and the university: A comparative study of civic engagement on five campuses. Nonprofits and Voluntary Sector Quarterly, 33(1), 74-93.

Piper, M. (2003). Building a civil-society: A new role for the human sciences. The Canadian Journal of Higher Education, 33, 113-130.

Strand, K., Marullo, S., Cutforth, N., Stoecker, R., \& Donohue, P. (2003). Principles of best practice for community-based research. Michigan Journal of Community Service Learning, 9(3), 5-15. 


\section{B. L. HALL}

University of Victoria. (2007). A vision for the future - A strategic plan for the university of Victoria. Victoria, BC: University of Victoria.

Wangoola, P. (2002). Mpambo, the African multiversity: A philosophy to rekindle the African spirit. In G. Dei, B. Hall, \& D. Goldin-Rosenberg (Eds.), Indigenous knowledges in the global contexts: Multiple readings of the world. Toronto, ON: University of Toronto Press.

Watson, D. (2007). Managing civic and community engagement. Maidenhead, England: Open University Press.

Wilkinson, R., \& Pickett, K. (2009). The spirit level: Why more equal societies almost always do better. London, England: Alan Lane.

Williams, L., \& Tanaka, M. (2007). Schalay'nung Sxwey'ga: Emerging cross-cultural pedagogy in the academy. Insights, 11(3), 1-21. Retrieved from http:/www.ccfi.educ.ubc.ca/publication/insights/ v11n03-/articles/williams/williams.html

\section{Budd L. Hall}

University of Victoria

British Columbia, Canada 


\title{
EMILIO LUCIO-VILLEGAS AND ANTÓNIO FRAGOSO
}

\author{
3. A TRAMP SHINING ${ }^{1}$ \\ The Popular (Community) Educator in the Age of Lifelong Learning
}

I will take my life into my hands and I will use it

(Jimmy Webb, MacArthur Park)

\section{INTRODUCTION: THE AGE OF LIFELONG LEARNING}

The introduction of the concept of learning at the centre of the educational processes seemed from the first to be a very positive issue (Faure, 1986; Guimarães, 2011). But the first thing that Lifelong Learning (LLL) policies and practices did was to transfer the responsibility of learning to individuals "who, in the last instance, are responsible for pursuing their own learning" (CEC, 2000, p. 5). In a certain way this means that a right is considered a commodity and, as Gomes and Lucio-Villegas point out, though it "promoted the expansion of education and training opportunities [it] has not yet guaranteed equal access for all” (2009, p. 75).

In the last 10 years, one of the most interesting and surprising achievements in education and learning has been the diverse attempts at a gradual unification of educational policies in the European Union. As Lima and Guimarães (2011) state, this is an important process that has limited national sovereignty. A Memorandum on Lifelong Learning can be considered the foundational document of the so-called Lisbon Strategy, primarily aiming to promote a "comprehensive strategy on lifelong learning" (CEC, 2000, p. 6). The 'Council Resolution of 27 June of 2002 on Lifelong Learning' stresses that the main goal of this policy convergence is "to achieve a comprehensive and coherent strategy for education and training" (OJEC, 2002, p. 2), making Lifelong Learning in Europe a reality. It is defined as follows. LLL encompasses:

[A]ll learning activity undertaken throughout life, with the aim of improving knowledge, skills and competences within a personal, civic, social and/or employment-related perspective. (CEC, 2001, p. 9)

The 'Memorandum', then, differentiates three types of learning: formal learning, non-formal learning and informal learning (CEC, 2000, p. 8). The Memorandum also states the main aims for this common policy on LLL through six key messages, all of which stress the importance of LLL (CEC, 2000, pp. 10-20). These messages are meant to help build a "knowledge-based economy and society" 
(CEC, 2000, p. 3) that will transform Europe into "the most competitive and dynamic knowledge-based society in the world by 2010 " (CEC, 2007, p. 2). The six key messages are: i) new basic skills for all; ii) more investment in human resources; iii) innovation in teaching and learning; iv) valuing learning; v) rethinking guidance and counselling; vi) bringing learning close to home.

- Lifelong Learning seems to be strictly linked with the labour market. In fact, the notion of LLL commonly used in our context derives from the European Employment Strategies in which we find the conclusion: "it was agreed not only that education and training throughout life helps to maintain economic competitiveness and employability" (CEC, 2000, p. 6). Lifelong Learning, as defined by the EU documents, tries to achieve two main goals: "promoting active citizenship and promoting employability" (CEC, 2000, p. 5). But, the latter seems the most important goal, giving the impression that the former is related to the maintenance of social cohesion, a very vague statement carrying an uncertain content.

- The goals that the European Union is trying to achieve with these policies are: i) to reduce labour shortages by raising skill levels in the workforce; ii) to address the problem of the high number of school-leavers by offering a second chance to receive a qualification; iii) to reduce the problem of poverty and social exclusion; iv) "to increase the integration of migrants in society and the labour market" (CEC, 2007, p. 3); v) to increase participation in the process of Lifelong Learning. The most important issue seems to be now to accumulate, in a personal way, skills that allow people - in theory - to have access to the labour market. Perhaps this could be a reason for the low levels of participation in LLL processes (Lucio-Villegas, 2012)?

- On the other hand, regarding the skills indicated in the first key message, it is important to stress that in practice they are addressed to a type of knowledge society that only focuses on Information and Communication Technologies. The idea of bringing learning close to home means to potentiate informal learning, but the danger is that this new valuing of informal learning seems to be enacted in conflict with the school learning system. Finally, concerning guidance and counselling, the Memorandum states:

The future role of guidance and counselling professionals could be described as 'brokerage'. With the client's interests in the forefront, the 'guidance broker' is able to call on and tailor a wide range of information in order to help decide on the best course of action for the future. (CEC, 2000, p. 16)

Perhaps, it could be interesting to reflect from a Foucaultian point of view which see the connections between guidance, counselling and power (see Nicoll \& Fejes, 2008; Edwards, 2008). Guidance and counselling, in fact, become very important in this time of discontinuous lives (Guimarães, 2011), where people feel insecurity, individuals have problems to find a job, to adapt to it and to stay in it. Guidance 
and counselling seem to be more related to promoting narratives of adaptation, to creating narratives about 'never for a long time' (Sennett, 2000).

- Finally, it has been argued that LLL means a type of countable model of education closely related to the notion of banking education drawn on by Freire. As Lima points out:

In education, managerial speeches have been occupying the position which was previously assumed by educational theories and pedagogical thinking, building narratives of a managerial type that legitimise a new social order based in the market and in the private and productive sectors, in economic competition and in client-centred management. (2000, p. 243)

\section{MEDIATION PROCESSES IN THE CONTEXT OF TODAY'S COMMUNITIES}

Against the notions of community characterized by homogeneity, it seems that today's communities can be better described by their diversity and by taking conflict as an important analytical category. The idea that there is a common division between 'us' and 'them', especially for the working-class (see Hoggart, 1966) is not new; this division functions often as a shelter against insecurities and 'the other' can be identified as the reason for these insecurities (Wildemeersch \& Vandenabeele, 2007, pp. 27-28). So conflict seems common, in the context of communities seen as heterogeneous spaces. In the public arena, debate, contradiction and deliberative democracy should be normal. Overall, community is not a place to protect people from the outside, because 'outside' is inside the community.

Mediation is, therefore, a necessary concept and practice in the context of community education and development processes. Mediation can be defined as describing the interaction between two opposed forces, in a way that the particular forms of mediation change the things being mediated (Williams, 1989). Mediation is always a political act in the sense that it includes values and necessitates a deep understanding of the context where things happen. The simpler forms of mediation are those that try to eliminate or prevent conflict between social actors or institutions (but even within this type of mediation that are very complex situations where social conflict is a fact); or to foster collective cooperation. But if mediation is taken as a constitutive part of community development projects, it can have the aim of promoting social change and empowering people. Possibly some brief examples can illustrate the complexity of mediation processes. In Fragoso and Lucio-Villegas (2010) we analysed the effects of forms of mediation on community development processes that went on in southern Portugal for an extended period of time (19852003). We identified three main phases. In a first phase there were three types of mediation processes: to facilitate and communicate; to solve conflicts between persons and community groups; and as a creation of social forms towards social change. This type of mediation was done by an association which, despite the fact of having a regular presence in the community, was from outside the community. In a 
second phase, this 'outside' association was not present anymore and the mediation processes were performed by local actors. Two forms of mediation "disappeared" and mediation for solving conflicts was the only form of mediation that was still present. Although this coincided with a very fruitful phase of endogenous action towards local development, conflicts between groups increasingly arose and there was a growing fragmentation of the collective dynamics, which slowly began to be replaced by individual protagonists. Therefore, the third phase was a logical consequence of these processes: mediation totally disappeared; conflict was everywhere, although more frequently implicit than explicit; the fragmentation of the community groups grew to a point where cooperation was blocked - creating the impossibility of any coordinated action that could defend people's view of strategic development.

This experience shows us that mediation can be crucial to the 'success' or 'failure' of community development processes. However, it also opens up the need to reflect on the mediators themselves. In fact, the ideal situation would be one in which popular educators acted as mediators, taking advantage of their integration in the community and having a deep understanding of the shifting contexts of the community and their social networks. However, this is a hard task full of structural obstacles in the way.

\section{BEYOND THE MEDIATION PROCESSES: NEW FORMS OF DOMINATION?}

If popular educators are to be mediators committed to social change, they have to have the full control of processes, in the larger contexts of a non-paternalistic participation process. This includes being able to fight important tensions and contradictions, which, in our opinion, can be done from the main contradiction 'In and against the State.'

We believe that it is essential that capitalism be seen not just as an economic system, but as a set of social relations. It determines the way we see ourselves and others, the way we treat each other, the way some people have control over other's lives. (LEWRG, 1980, p. 4)

From this point of view we must look at the State not only as a provider of services, but as a form of people's relationships with a focus on elaborate structures of control - not only forms of oppression in the sense described by Freire - that build a social consensus in the same way that Gramsci describes Hegemony. This means the work done to analyze the State's structure as a form of domination, is important but not fundamental. From our perspective, it is crucial that we reinforce the role of the State - as the provider of welfare - and, at the same time, reveal the concrete social relations that make up these forms of domination.

The major contradiction 'In and against the State' is related to the social relationships that the new capitalism is building. Almost a century ago Antonio 
Gramsci, while reflecting on the causes of the defeat of the working class in Italy, developed a response to the following questions: How are these relationships imposed? How can we deal with specific relationships in capitalism? How can we transform these relationships in a situation defined by domination? The notion of hegemony and the possibility of diverse hegemonies fighting simultaneously in the same social structure were proposed as able to answer the questions above.

The major issue now is related to these forms of domination and their influence in people's daily lives. Hardt and Negri (2005) called this form of domination based on a non-specific power, place or form of exploitation 'Empire'. This new (or old) form of domination is based on dominating the entire lives of men and women, in controlling their forms of expression, thought, feeling, sexuality, etc.

When analysing the consequences of the New Capitalism, Richard Sennett reflects on The Corrosion of Character (Spanish edition, 2000). It is important to stress that for Sennett character is not related to personality in a psychological way but it is related to the way in which we organize our relations with the other. And these relationships are closely connected with three main issues that give form to flexibility: a discontinuous re-invention; a flexible production; and power concentration without centralization. In the end, it is used to organize a specific way of life characterized by 'never for a long time'. Narratives are created in a flash, not as a career. A relationship between people in communities, solidarity, are neglected. The feeling of community that Raymond Williams describes in Border Country is not possible within the structure of a flexible society:

They were very conscious of being left alone, but when the day started the news spread quickly and a process began which was to take over and control all that had happened: a deliberate exertion of strength by this close community, made as, always, for its members who needed help, but made also, it seemed, for the sake of the village, to prevent anything reaching out and disturbing its essential community. (Williams, 1960)

These kinds of relationships between people are broken by the dominant forms of production. As Crowther points out: "The bonds that create trust, loyalty and mutual support between people can only be nurtured through establishing long-term commitments" (2004, p. 126).

On the other hand, communities are now being used as a substitute of the State. Communities are presented as providers of services, but without the resources to supply these services. It is another consequence of the contradiction 'In and against the State' and, in communities, educators and social workers are in the firing line of people's claims.

How can we build both bonds and profound relationships in the flexible world? How do we enlighten practices in communities? How do we cultivate practices of both solidarity and resistance?

In Respect in a World of Inequality (Spanish edition, 2010), Richard Sennett considers that the relation between social workers or educators and people in 
communities must be based on respect. This respect is built in a relationship based on a listener attitude toward people's stories. Reciprocity is the foundation of respect.

With time, individual life stories cross in complex ways so that history can deny to a person the understanding that has been given to another. (Sennett, 2010, p. 246) ${ }^{2}$

These stories are related to the kind of knowledge that we can call explicit knowledge.

Respect is an expressive behaviour. This means that treating others with respect is not something that simply happens, not even with the best will in the world; to show respect is to find the words and the gestures that allow the other not only to feel it, but also to feel with conviction. (Sennett, 2010, p. 213) ${ }^{3}$

In this sense, the question we should ask ourselves is the following: is the building of respect an educational process? If the answer is yes, is it related to popular education? Is it related to a shift in the hegemonic social relations deriving from the State? If the response is yes, we can consider a new front against the State: building respect among people.

\section{MODELS FOR THINKING ABOUT THE EDUCATOR}

Thinking in terms of respect, what models can be considered in order to organize educational processes together with people in communities?

\section{Gramsci and the Organic Intellectuals}

Perhaps one of the most original developments in this regard is Gramsci's idea of the organic intellectual. To explain this we need to define the sense of organic. Williams says: "It has also an important applied or metaphorical meaning, to indicate certain kinds of relationships and hence a certain kind of society" (1986, p. 227). Being so, we can argue, as a first idea, that an organic intellectual means a person - or group of people - in relationships.

Gramsci has drawn on the concept of organic intellectual as:

the one who emerges in response to the demands of a necessary function in the field of economic production. Therefore, for example, the capitalist entrepreneur creates with himself the industrial technician. In his turn, the labourer constitutes the union organizer and the professional revolutionary, also as organizers of a new culture. (Gramsci, 1974, p. 22) ${ }^{4}$

The organic intellectual's role develops through persuasion and consensus. Thus, connections between the organic intellectual and hegemony are evident. Each class in conflict for control of society is helped by a specific kind of intellectual who defines the rules that organize social life. As Popkewitz states: 
The intellectual changes himself into the expert by legitimating what influences his moral conduct and will, controlling the exchange of ideas through which a society establishes its aims and evaluates its institutional conditions. (Popkewitz, 1988, p. 219)

Intellectuals are not neutral. They address - according to their position - important issues concerning the whole people's social life. In fact they choose, as Thomas Isaac and Franke stated (2005), between bureaucracy and rational management or, by joining with people, they trigger development processes. This choice is rich in aesthetic elements.

The problem Gramsci seeks to resolve is how to produce this intellectual role from subordinate groups with little previous experience of generating their own leaders, who are able to articulate grievances in terms that connect the problems experienced by subordinate social groups with an analysis that goes to the root of the problem in terms of the virus of capitalist social relations. The challenge is a significant one:

If our aim is to produce a new stratum of intellectuals including those capable of the highest degree of specialisation, from a social group which has not traditionally developed the appropriate attitudes, then we have unprecedented difficulties to overcome. (Gramsci, 1970, p. 43)

This point is very important when thinking in terms of hegemony. According to Crowther and Lucio-Villegas,

Knowledge, feeling and understanding come out of a process of sustained educational engagement. The relationship between the popular and the intellectual is a critical one for the emergence of a persuasive hegemony sufficiently robust to challenge common sense. (Crowther \& Lucio-Villegas, 2012, p. 62)

The idea of the organic intellectual points towards the notion of choice. This allows us to show that mediation is not a neutral process. It can be positive or negative in its relationships to people. It can empower people or maintain a kind of banking education. Aesthetic options include the experts' engagement as 'us' or 'them'.

\section{Popular Education and the Pedagogy of Love}

This kind of intellectual could be represented, for instance, by the teacher teaching literacy (as, for example, in the context of Nicaragua). The main importance of these educators goes beyond their work in the field of literacy; their role is crucial and organic when they connect this literacy work with food security, community and personal health, the environment, the labour market and the emergence of community productive sectors, etc.

According to Pineda (1999), Popular Education can only be understood as such if it is related to people's daily lives and if it helps people to overcome their difficulties 
and to build a better life. To Pineda the first phase of an educational process is falling in love (enamoramiento, in Spanish). This means that people adopt a strong and positive attitude to education because they understand the necessity of education to change their lives and their communities, etc.; and also because they discover that Popular Education means to build new relationships between people and between people and nature.

According to Crowther, Johnston, Martin and Merrill (2006), Popular Education is popular because it is:

- rooted in the real interests and struggles of ordinary people;

- overtly political and critical of the status quo;

- committed to progressive social and political change.

And the methodology of Popular Education is based on the following common points:

- its curriculum emerges from the concrete experience of resistance and struggle and from the material interests of people in communities;

- its pedagogy is collective, focused primarily on the group as distinct from individual learning and development;

- it attempts, wherever possible, to forge a direct link between education and social action.

Consequently, the connection between Popular Education, popular educators and people's wishes and desires is a method to break the relationships deriving from the New Capitalism and a way to keep alive the contradiction 'In and against the State'.

\section{LEARNING FROM LEARNERS' PRACTICES}

It is important to create a kind of narrative about practices that can enlighten us regarding other practices and experiences. To create these narratives can help us to reflect and to look to our future work with an individual chronicle that we can share with other individuals. These narratives of practices are built in many different ways within the inter-subjectivity between social actors. Maybe it is useful, in this sense, to look at a case study carried out in southern Portugal in a community amateur fishing club (Ricardo \& Fragoso, 2013). The amateur fishing club in Faro was created in 1956 by a group of eleven friends. Initially they held their own competitions and were dedicated to teaching fishing to other adults and young adults. Soon, however, they put together a team and started to compete officially.

It is very important to understand how they learn to fish - particularly because they are amazingly good at it, at all levels. In regional competitions, as the maximum number of team members per club is six, they 'lend' some of their anglers to other clubs so that the competition is more balanced. The club is one of the best in the country (it is in the top three at national level). They have won a large number of individual and team trophies at events that include worldwide competitions. They 
have various members (men and women) who hold the title of world champions. Therefore, it seemed logical to inquire whether the club has organised some type of structure to support the technical aspects of fishing. Surprisingly, this is not the case. The club has no financial support, no appointed or hired coaches, no organised training sessions nor any type of planned training structure. Its members simply go on frequent fishing trips together, mostly at weekends, and learn together from practice and from each other. Informality, friendship and family social relationships seem to be the basis of their success. In social events, for instance, it is very frequent to have three generations fishing together at the beach. This intergenerational learning extends to other dimensions, such as simple socialisation, visible in the social spaces at the club.

This club is also capable of establishing important ties with the larger community. A number of people of the community, who are not members of the club or care for fishing, use the club spaces and especially the bar for socialisation. Club members are often volunteers for community action, especially in activities related to the environment, the sea, or the lagoon. They participate in cleaning initiatives in green spaces or the islands surrounding Faro and participate in other club activities. When they organize social fishing events, the fish they catch is given to institutions that work with the homeless or older adults who are impoverished (frequently more than $100 \mathrm{~kg}$ of fish). It appears, therefore, that the shared narratives do not relate only to the technical details of fishing. These people are capable of building collectively narratives of citizenship and participation that are rooted in their daily practices in the community.

\section{CONCLUSIONS}

A first conclusion goes directly to our chapter's theme. In fact, some of the positions we have identified for experts and their relationships with people are effectively in opposition to each other. This calls our attention to the fact that the building of these relationships can culminate in very positive processes or, alternatively, in the emergence of important obstacles to the fluidity of local development processes. Hence two kinds of reflection can be made: first, the importance of mediation is precisely that a well-defined and planned mediation process can be part of local development activities, and can prevent the emergence of obstacles and promote co-operation between social actors - which, as we know, is fundamental in this type of process. Secondly, research can be directed to unearth the factors that influence, at a basic level, the relationships between experts and people. However, contextual factors that define the situations can have central importance, too. For example, in the informal space of the amateur fishing club no formal or informal mediation is taking place, precisely because of the types of relationship that members have established among themselves. These are not the traditional relationships we see in mainstream educational contexts, but the informal character of such spaces defines relationships in which Sennet's respect becomes visible. In this way, they are all experts, able to constantly teach and learn from each other. 
We want to emphasize one or two other points very briefly. First of all, we stress the importance of working with people - not for people. Participation is, for us, a key concept in this issue. The Popular Educator must promote participation and not substitute it. In this sense we need to rethink the idea of mediation and organize ways to construct a politics of mediation in a participatory way. This aspect is also linked with the search for autonomy, the creation of respect and the promotion of popular knowledge. On the other hand, participation is an essential element for creating different relationships among people to potentiate democracy (Heller \& Thomas Isaac, 2003).

Secondly, it is important to consider the idea of empowerment in the sense that the presence of the educator is provisional, not definitive. The educator should develop an educational process to invite people to take into their hands the processes of development. This is the fight for autonomy which comes to us from the Enlightenment. If the model of educator in the age of Lifelong Learning seems to be closer to control through guidance and counselling - as Nicoll and Fejes (2008) state - the popular and community educator should be closer to Lengrand's statement:

The only fruitful thing that an educator can do for adult learners consists in facilitating their skills and positioning the adults in situations in which they can, through the elements of their own condition, through their daily experiences, from their struggles, from their successes and failures, build personal knowledge and reflection. $(1973, \text { p. } 20)^{7}$

This means creating a narrative to build personal and social development far away from the restrictions of Lifelong Learning policies and practices.

Finally, it is central to stress some contradictions related to the idea of community. Community is presented as responsible for all things. The State, as provider of welfare, transfers this responsibility to the community. This load of responsibility means that Popular Educators bear the weight of guaranteeing welfare, but not the provision of the resources. Suddenly the Popular Educator needs to deal with the claims of the people and, because of this, sometimes they cannot do their work. This is the trap laid by the State.

\section{NOTES}

1 "A Tramp Shining" is an album performed by the actor/singer Richard Harris, published in 1968, including the famous single 'MacArthur Park'.

Our translation.

Our translation.

Our translation.

Our translation.

Our translation.

Our translation. 


\section{REFERENCES}

Avritzer, L. (2003). Modelos de deliberação democrática: Uma análise do orçamento participativo no Brasil. In B. S. Santos (Org.), Democratizar a democracia: Os caminhos da democracia participative. Porto, Portugal: Afrontamento.

Commission of the European Communities. (2000). Commission staff working paper: A memorandum on lifelong learning. Brussels, Belgium: European Union.

Commission of the European Communities. (2001). Making a European area of lifelong learning. Brussels, Belgium: European Union.

Commission of the European Communities. (2006). Adult learning: It is never too late to learn. Brussels, Belgium: European Union.

Commission of the European Communities. (2007). It is always a good time to learn. Brussels, Belgium: European Union.

Crowther, J. (2004). In and against lifelong learning: Flexibility and the corrosion of character. International Journal of Lifelong Education, 23(2), 125-136.

Crowther, J., \& Lucio-Villegas, E. (2012). Reconnecting intellect and feeling: Marx, Gramsci, Williams and the Educator's role. In B. Hall, D. Clover, J. Crowther, \& E. Scandrett (Eds.), Learning and education for a better world. Rotterdan, The Netherlands: Sense Publishers.

Crowther, J., Johnston, R., Martin, I., \& Merrill, B. (2006). Defending the radical margins of university adult education. In A. Antikainen, P. Harinen, \& C. A Torres (Eds.), In from the margins. Rotterdam, The Netherlands: Sense Publishers.

Edwards, R. (2008). Actively seeking subjects? In A. Fejes \& K. Nicoll (Eds.), Foucault and lifelong learning. Governing the subject. London, England: Routledge.

Faure, E. (Ed.). (1986). Aprender a ser. Madrid, Spain: Alianza.

Fragoso, A., \& Lucio-Villegas, E. (2010). Looking back through a new pair of glasses: Conflict and mediation in local development: Spatial and organizational dynamics. Sociological and Educational Studies, 5, 68-79.

Gomes, I., \& Lucio-Villegas, E. (2009). Recognition of lifelong learning and lifewide learning within the scope of permanent education. In E. Lucio-Villegas (Ed.), Citizenship as politics: International perspectives from adult education. Rotterdam, The Netherlands: Sense Publishers.

Gramsci, A. (1970). Introducción a la filosofía de la praxis. Barcelona, Spain: Península.

Gramsci, A. (1974). La formación de los intelectuales. Barcelona, Spain: Grijalbo.

Guimarães, P. (2011). Politicas de Educação de Adultos em Portugal (1999-2006). Braga, Portugal: Universidade do Minho.

Hardt, M., \& Negri, A. (2005). Imperio. Barcelona, Spain: Paidós.

Heller, P., \& Thomas Isaac, T. M. (2003). O perfil politico e institucional da democracia participativa: Lições de Kerala, India. In B. Sousa Santos (Org.), Democratizar a democracia. Os caminhos da democracia participative. Porto, Portugal: Afrontamiento.

Hoggart, R. (1966). The uses of literacy. London, England: Pelican.

Lengrand, P. (1973). Introducción a la Educación Permanente. Barcelona, Spain: Teide/UNESCO.

Lima, L. C. (2000). Educação de adultos e construção da cidadania democratica: Para uma critica do Gerencialismo e da Educação Contábil. In L. C. Lima (Ed.), Educação de adultos: Forum II. Braga, Portugal: Universidade do Minho.

Lima, L. C., \& Guimarães, P. (2007). European strategies in lifelong learning: A critical introduction. Opladen \& Farmington Hills, MI: Barbara Budrich Publishers.

London Edinburgh Weekend Return Group. (1980). In and against the state. London, England: Pelican.

Lucio-Villegas, E. (2012). What's going on? An overview of adult education policies in Spain. Journal of Adult and Continuing Education, 18(1), 77-89.

Lucio-Villegas, E., \& Fragoso, A. (2009). Doing expertise? A reflection on the relationship between people and experts in local development. In R. Evans (Ed.), Local development, community and adult learning: Between the mainstream and the margins (Vol. 1). Magdeburg, Germany: Nisaba verlag. 


\title{
E. LUCIO-VILLEGAS \& A. FRAGOSO
}

Nicoll, K., \& Fejes. A. (2008). Mobilizing foucault in studies of lifelong learning. In A. Fejes \& K. Nicoll (Eds.), Foucault and lifelong learning: Governing the subject. London, England: Routledge.

Official Journal of the European communities. (2002). Council Resolution of 27 June 2002 on Lifelong Learning.

Pineda, O. (1999). La Pedagogía del Amor en Nicaragua. Barcelona, Spain: AEPCFA.

Popkewitz, Th. (1988). Paradigma e ideología en investigación educative. Barcelona, Spain: Mondadori. Ricardo, R., \& Fragoso, A. (2013). Older men learning in the community: The case of the amateur fishing club of Faro. In Irena Žemaitaityt \& Sarmit Mikulionien (Eds.), Proceedings of the 4th International Conference: Learning Opportunities for Adults: Forms, Providers and Policies. Vilnius, Lithuania: Mykolo Romerio University.

Sennett, R. (2000). La corrosion del carácter. Madrid, Spain: Anagrama.

Sennett, R. (2010). El respeto. Madrid, Spain: Anagrama.

Thomas Isaacs, T. M., \& Franke, R. W. (2005). Democracia local y desarrollo. Barcelona, Spain: Diálogos.

Wildemeersch, D., \& Vandenabeele, J. (2007). Relocating social learning as a democratic practice. In R. van der Veen, D. Wildemeersch, J. Youngblood, \& V. Marsick (Eds.), Democratic practices as learning opportunities. Rotterdam, The Netherlands: Sense Publishers.

Williams, R. (1960). Border country. London, England: Parthian Books.

Williams, R. (1985). Keywords. London, England: Fontana.

\section{Emilio Lucio-Villegas}

University of Seville, Spain

\author{
António Fragoso \\ CEIC, University of Algarve \\ Faro, Portugal
}




\section{SYMBOLIC CLOSING OF LOCAL COMMUNITY AND REFLEXIVITY}

This chapter focuses on research done over a total period of six years, initially in three communities, and subsequently in one further local community in Poland, in which I analysed the process of the closing of symbolic spaces. My attention has been directed toward the communities which have experienced 'broken' historical continuity. The aim has been to elicit the shared values of people in the communities and to discuss the potential for looking to the future. The findings confirm that each community follows its own path of development and the character of that development is dependent on numerous 'soft factors', among which the competence of reflexivity seems to be a key concept.

\section{INTRODUCTION - THE SHIFTING MEANING OF COMMUNITY}

Lyn Tett (2010) summarizes the community as a category and she pinpoints its three main areas of meaning: place or locality, interest and function (p. 12). In her view, each meaning can generate the boundaries which may be physical, religious and linguistic, as well as those which can exist in the minds of the beholders (Cohen, 1985, p. 12 in Tett, 2010, p. 12). Thus, speaking about the "boundaries" it can be assumed that social polarisation ranging from generating positive relations to reinforcing potential conflicts is an inevitable part of community life. As Tett warns, thinking about the community only as a positive romantic relationship between its inhabitants can narrow our understanding of the real learning spaces which in fact exist there. This critical perspective toward the tendency to 'romanticise the neighbourhood concept of community' focuses our attention on different socioeconomic forces which can make people live in a community against their will or at least without their feeling any sense of belonging to it (Shaw, 2008, p. 29 in Tett, 2010, p. 12). What especially interests me in my research is the category of belonging, which seems worth analyzing in the context of thinking about community as a place which can play a symbolic role in generating people's sense of identity (Tett, 2010, p. 12), constituting the symbolic status of the place and serving as a projection of community life in the future.

In the Polish socio-historical context the category of symbolic belonging to a community and identification with a locality seems to be a crucial factor in the data collected by social scientists during the last two decades (Jałowiecki \& Szczepański, 
2002, 2009; Łukowski, 2002, 2009; Kurantowicz, 2011; Malewska-Szałygin, 2002; Ligus, 2009; Traba, 2007). For over twenty years the meaning of community has been continuously saturated since the political turn in $1989 .{ }^{1}$ What is a real contribution to social life is the fact that since then the category of community development has become present in both political discourse and in practices and initiatives taken up by locals (Kwiatkowski, Michalak, \& Nowosad, 2011; Zagórski, 2009).

In Poland the development of local community has passed through stages which are strongly subordinated to our political periods - communistic, post-communistic and democratic (Kurantowicz, 2011, pp. 89-101). Apart from the national tendencies, community development has followed multilevel paths which in turn are embedded in the socio-cultural contexts of Poland's regions. From my experience as a researcher, special attention should be directed to those places (communities) which have had their historical continuity broken and which are currently struggling to close with their past. To make the problem more clear, it should be borne in mind that in Poland over 100,000 square kilometres (out of 322,575 km²) are located in borderlands which cover the territory perceived as having an interrupted cultural continuity after World War II. In those communities the break with the past influences the present picture of individual and collective life. That is why there are many communities which are re-conceptualizing their identity and at the same time are struggling to build up the bridges between a blurred past and an unpredictable future. What is most important in widening informal and non-formal learning spaces, such communities do this through social and/or political negotiation. That is how we can describe the current state of community activism in Poland and to illustrate this I will present a comparison between three communities (three case studies) which are both examples of people's responses to changing circumstances (Brent, 2004, p. 221, in Tett, 2000, p. 13) as well as their own way of stating the symbolic status and closing the symbolic space of their place of living. After that, I present in more detail interview data from a fourth community (the interview with 'Monika' below) in which the role of refexivity in achieving symbolic closing is proposed.

\section{SOME BACKGROUND NOTES ON THE NEED FOR (RE)CREATING THE SYMBOLIC SPACES IN LOCAL COMMUNITIES}

According to the data, the turning point for all and every Polish local community was the year 1989. Before there were only political-administrative projects focused on fulfilling centralized instructions without even thinking about the localities as having a potential for self-directed actions or for creating their own identity. By contrast, after the year 1989 there were no more such projects on the national level (Lukowski, 2009, pp. 171-175). At the very beginning this created the feeling of a gap between the "habitual pattern" from the past and the lack of any "pattern" which might be useful in times of significant transformation. This emptiness very quickly turned into a dynamic building up of structures and institutions of civic society which at that time were extremely motivated to participate in local society. 
On the other hand, there was a lack of experience in civic public activity as well as civic education, which caused a stagnation of local development in the second half of the 1990s (Kurantowicz, 2011, pp. 95-96).

However, the 1990s was a decade when the new localism was being rethought all over the country. The territories with a "broken cultural continuity" doubled their effort to re-conceptualize their identity in a new political and social milieu. Social researchers pinpoint some reasons which they perceive as the main arguments and interpret as "looking for the new 'substance' of the post-communist order that can be selected from both our own ideological and institutional heritage as well from foreign sources" (Staniszkis, 2001, p. 139). Arguably, what has happened in Poland is that intellectual elites sometimes unconsciously overused neo-traditionalism to face the problems confronting them (Staniszkis, 2001, p. 137 in Łukowski, 2001, p. 268; Łukowski, 2009).

By using a socio-historical approach to elicit the collective experience of peripheral local communities and their interpretation of belonging to the space/ place/community in Poland, certain "soft factors" have been introduced which focus attention on analysing the motives communities had in recreating the new symbolic spaces and in then completing the work of symbolic closing at local/ regional level. Among a number of different reasons for these processes the researchers suggest:

- The psychological and cultural need of intergenerational and historical continuity. After the political changes, the will to, and the psychological and cultural need for, intergenerational continuity becomes a local/regional project and a challenge. This does not take place in a linear fashion: it is heterogenous to the core. The impression is created of green positive islands emerging from the grey and flat area around them. These processes have no regularities. Sometimes they are covered up by everyday official interactions and remain invisible until some spectacular fact comes to light and are then openly recognised. This kind of local activism causes both positive as well as grotesque results. Strange or grotesque outcomes can sometimes be understood as evidence of a desperate search for genuine innovation in the process of constituting a new cultural fabric for the community (Łukowski, 2009, p. 172).

- The next important reason is the work which was done by local communities to legitimise their living and gradual taking-root in the territories incorporated into Poland after World War II. They faced the problem of the 'broken' past of both the people and the territories. In this case the psychological work that was necessary was supported by political efforts, such as involvement in European integration (EU accession of Poland in 2004) and normalization of relations on an international level with Germany, Russia, Lithuania, Ukraine, Belarus and other countries (Lukowski, 2009, p. 172). ${ }^{2}$

- The popularization and influence of communitarian perspectives also played a role, according to which we all consciously or unconsciously belong to a 
community within which we are able both to understand ourselves and create our identity by rethinking the new shape of our community (Łukowski, 2009, p. 172).

- The role of old/new traditions is connected with looking for new 'substance' with the help of which to conceptualize and/or re-conceptualize the local/ regional identity. That means the need to work over the new symbolic status, symbolic cohesion and the symbolic closing - all of these terms are explained below - of local communities (Łukowski, 2009, pp. 171-182).

Creating a new (collective) tradition is a process which requires the ability to separate from the rigid past and at the same time be ready for reflexive analysis of the processes of individual/collective self-identification. The power to create a new concept of community is embedded in people's mentality and can be recognized through:

- the positive emotional attitude toward self (and local) identification;

- the experience of being rooted in cultural tradition as well as gradual binding with the surrounding natural environment;

- the ability to negotiate a new understanding of the processes which influence the community from the outside as well as from the inside;

- the ability to cross fixed boundaries, to re-create 'accustomed' reality;

- the ability to interpret and re-read the flexible world on all levels, micro-, mesoand macro (Łukowski, 2009, pp. 174-175).

All of the abilities mentioned above are part of the process which can be found in the community, from symbolic cohesion and status to the symbolic closing of space.

In Poland the experience of crossing the symbolic territory from a nondemocratic system in which the meanings were handed down to the community and had only an administrative sense, to a democratic system in which the symbolic space can be an intellectual creation of an imagined future, has had the effect of empowering autonomy. It has also given the feeling of being creative in a world which needs the concept of an "open regionalism" instead of a "closed one" (Łukowski, 2009, p. 172).

\section{What is the Contribution of Symbolic Status, Symbolic Cohesion and Symbolic Closing to Community Life?}

From the perspective of social scientists the symbolic space can include both pictures and places related to important values which are interconnected with the community past. The role of the past has been to create the unified picture of local/regional identity. Symbolic space can start from symbolic sculptures, buildings or districts and come to current symbolic rituals, or recognized behaviours which can be a part of (local) ideology and values (Jałowiecki, 2002, p. 353). In other words the symbolic space is a kind of heritage which allows the development of both social and political subjectivity (Łukowski, 2002, p. 267; Zieliński, 2001, p. 201). Symbolic community 
space can have side effects when it becomes a barrier to social development. In this way it can bring about stagnation, but at the same time it can give empowerment to the processes of re-conceptualization of the new identity which has to be re-shaped in the permanently changing world.

However, the symbolic space struggles for symbolic cohesion, which in turn is a decisive element in determining the quality and attractiveness of the local/regional territory. Symbolic cohesion can be seen as a combination of life quality, social integration and cultural (educational, mental) abilities, which together create a quality of symbolic status. There has, of course, never been an example of pure, ideal symbolic status, but it has always been a mixture of positive and negative features, which in fact are very ambivalent and which give rise to an interplay between various aspects of social relations. The symbolic status is created by comparisons with either certain societies (formal, informal groups) or by comparison with the former patterns of social life. However, there has been another way of creating symbolic status. This is by promoting the 'uniqueness' of the place, people or local achievements. In practice the ways of creating symbolic status are closely interwoven and it is difficult to separate them (Łukowski, 2009, pp. 172-173). In this research I present examples of four different ways of creating the symbolic status in communities and comment on the closing of the symbolic space of community life.

Symbolic closing is a state of mind in local/regional society. It appears together with the self-understanding of the community and an acceptance of being different, having self-generated local wisdom, and with the optimal level of emotional attitude toward the society. The positive emotional energy is the result of a high level of social trust. The lack of trust slows down and brakes all initiatives and leads to the erecting of walls between different groups. Symbolic status can contribute both to the attractiveness' of the place or to its marginalization. However, the process of closing the local/regional space leads gradually to symbolic cohesion (Collins, 2005, p. 121). A shared feeling of uniqueness and an appreciation of the specific features of local community, saturated with important and significant meanings, positive emotional energy and trust must first be created. The process of constituting the symbolic status of a community runs on two parallel levels - the reflexive and the habitual level. This is what Archer (2010) describes as "morphogenesis and reflexive action" and presents them as mutually interwoven interaction between the culture and the structure of a community over the course of time.

Looking at Polish experience, a number of processes can be identified involving the reinterpretation of local/regional identity as a part of the process of closing the symbolic community space:

1. Re-scaling, that is, focusing on gaining completely new abilities and possibilities of active participation on a regional level. The aim of re-scaling is to overcome the peripheral location of the community by breaking through barriers of provincialism and parochialism to connect different pieces of traditions which had been separated by strong symbolic borders. 
2. Formatting - creating an image of high-level cultural competences and abilities for cooperating with partners from outside of the region.

3. Looking for a new 'substance' to create new regional social bonds. Regions can offer communities the feeling of real borders, but at the same time, when the project is very open-ended, regional bonds can be a protection against the fatalism of parochial locality (Staniszkis, 2001, p. 139; Łukowski, 2002, pp. 268-270).

\section{Methodology}

The research was designed following the qualitative case study method of social inquiry (Denzin \& Lincoln, 2009, pp. 623-654; Miles \& Huberman, 2000), employing qualitative methods such as narrative interviews, long-term observation and documentary analysis. The first stage of the research was conducted in 20062009 in three small towns A, B, C (with 6,000, 15,000 and 18,000 inhabitants respectively). All of the towns belong to the same region (the North-Western part of Poland) and are located no further than $45 \mathrm{~km}$ from one another. After interpreting and describing the first results I began looking for any other conditions that finally help the locals to "close' their unclosed private/public spaces. That became the second stage of the project, conducted in the years 2011-2014 in another village in the South-West of Poland, that has the same historical background as the towns A, B, C. At this stage I deliberately chose for the interviews the third generation of local active /inhabitants born in those communities in the 'seventies of the twentieth century (the first generation was born after the year 1945).

I started my research by conducting narrative biographical interviews among local people (6 in each community) and selected experts (Deputy Mayor, NGO activist, a small business owner, an artist, the president of a Cultural Centre). The first data collected through the interviews was important in order to elicit the local meanings which are specific for each of the local spaces. The next thing was to recognize social actors' attitudes toward their place of residence. That stage resulted in a collection of phrases, stories and arguments spoken in the course of the interviews. The interesting thing was that some phrases were constantly repeated by the inhabitants of each of the towns. In the second stage of the project, in the fourth community, there were a further six interviews. For this chapter I have chosen only the episodes from Monika's narration (a 40-year-old NGO activist).

\section{The Questions}

I was inspired to a great extent by the notion of being an "active agent" as proposed by Archer (2007). According to her explanation of the term:

Individuals develop and define their ultimate concerns - those that they care about most - and whose precise constellation makes for their concrete singularity as persons. No one can have an ultimate concern without doing 
something about it. Instead, each seeks to develop a course(s) of action to realise that concern by elaborating a "project', in the (fallible) belief that to accomplish the project is to realise one's concern. If such courses of action are successful, which can never be taken for granted, each person's constellation of concerns, when dovetailed together, becomes translated into a set of established practices. This constitutes their personal modus vivendi. Through this modus vivendi, subjects live out their personal concerns within society as best they can. In shorthand, these components can be summarized in the formula Concerns $\rightarrow$ Projects $\rightarrow$ Practices. (Archer, 2007, p. 42)

In fact my research questions were quite general and I was looking for the data which would satisfy my interest according to these questions:

- How do the people experience living in a community with a 'broken' historical continuity?

- What makes the individual (as well as community groups of actors) look to act according to the formula: Concerns - Projects - Practices?

- How do the people select their concerns?

- To what extent do people live out their personal concerns while at the same time acting as a part of society?

- How much are the individual concerns tied up with the symbolic space of the local community?

- To what extent does the symbolic space influence the individual concerns and create their modus vivendi?

\section{SELECTED FINDINGS - 1ST STAGE OF THE PROJECT}

Some examples of statements elicited from the interviews can help to show some of the main differences among local actors in interpreting the social space.

\section{A) Repeated Phrases and Selected Meanings}

Community A (6000 inhabitants):

I wish I could I escape from that place / I think I will not stay here for a long time / I thought to myself, everywhere but not here / I did not like to stay here and did not like my children to live here / nothing to speak about and nothing to think about / it was not my place, it was the place of my work

Meanings:

a. Positive: a calm place to die / unchangeable / good for old people

b. Negative or ironical: a hole of a place / fucking metropolis, a good place for intruders and gossipers / nothing to gain nothing to lose / our community is so poor 


\section{R. LIGUS}

Community B (15000 inhabitants):

Our place is such a beautiful one / there is no better place for living than here / I will never go anywhere else / this is the paradise of this world / you have everything here, even the lake in the town centre / the nicest place I have ever come across / I would never leave this place / I came here 40 years ago and I fell in love with all of this - nature, the lake, the climate, and everything

Meanings:

a. Positive: I love this town / you have everything you need here / a paradise / a factory of talents / the source of intelligent people / a strong and rich place / diversity of people / intercultural / tolerant / powerful

b. Negative or ironical: too small to live too nice to leave

Community C (18000 inhabitants):

This is not a place for young people / too much politics in everyday life / I do not like the arguments between local parties / local politicians care about their position but do not care about us / for whom did they build the golf course, because it is not us, the people / the streets are empty, there is not a pub or coffee shop / when you finish school you have to look for another place / nowhere to go nowhere to play, nowhere to stay

Meanings:

a. Positive: I like the lake / in summertime it is a perfect place / good artistic competitions / a big cultural centre / the railway station is a window for the world

b. Negative: empty space / dull and too serious for me / not for living only for visiting

\section{B) The Analysis of Strong and Weak Sides of Each Community}

The data collected in interviews pointed to three main areas mentioned by those interviewed:

B1: The local leaders (both self-activists and the political ones; their visions, missions, interest in local development, projecting the future, mutual cooperation with other subjects)

B2: The support of local government given to the people in their symbolic space

B3: The recognition of, and positive reaction to, the initiatives, the acceptance, bottom-up support of existing or invented activities given by the local actors

Here I offer a very schematic specification of the criteria mentioned in B1, B2, and B3 which were elicited from the data collected in interviews conducted in all three communities: 


$\begin{array}{llll}\text { Community A: B1 (-) } & \text { B2 (-) } & \text { B3 (-) } & \text { Result (-) } \\ \text { Community B: B1 (+) } & \text { B2 (+) } & \text { B3 (+) } & \text { Result (+) } \\ \text { Community C: B1 (+/-) } & \text { B2 (+/-) } & \text { B3 (+/-) } & \text { Result (+/-) }\end{array}$

Even this short summary suggests that the quality of life, people's evaluation of their place of residence, and their readiness to imagine the future and accept the opening of new learning spaces is the result of mutual empowerment of (at least) three sides of the same 'triangle':

- the emotional, positive engagement of the leaders and significant others in creating the social milieu;

- the local government support in creating the symbolic space;

- and positive interaction among all the subjects together with the support and empowerment by social actors.

What is crucial in the narrations from communities A, B, C is that only rarely is the pronoun "we' used. Most of the statements express individual attitudes to the experience of community in their place of residence. Nevertheless, after collecting the results summarized above, it was possible to describe the basic conditions that support the locals in expressing their private concerns about the symbolic cohesion, the symbolic status, and closing the symbolic space of their community (Kukowski, 2009 , p. 173). However, it was still not possible to say to what extent the symbolic space influences individual concerns and creates their individual modi vivendi as well as collective local concerns. Yet another question was: how is any individual experience of closing such symbolic space documented in their narration? I was looking for answers to such questions while conducting the second stage of the project. From my point of view I have indeed found some evidence of social processes following the formula Concerns - Projects - Practices, and of a change in thinking about closing symbolic spaces that re-conceptualizes the way of doing it. In the fourth community D (1000 inhabitants close to a town of 36.000 in the South-West of Poland) interviews were conducted with two local NGO leaders, a local government representative, 2 members of the local folk music association, and a local business leader). I have chosen Monika's interview to show the process of becoming part of the community by following the path 'from me to myself' (Monika, 40-year-old local NGO leader). Her experience seems to be a good illustration of the parallel processes of constructing biographical identity through reflexive analysis, rethinking and finally re-conceptualizing self and community identification.

\section{SELECTED FINDINGS - 2ND STAGE OF THE PROJECT}

\section{Episode 1 Community: Monika (40) I did not know anything ...}

Once I remember when a few years ago together with a group of my local active friends we were looking for something special, something unique, 
some historical episodes that carry some important meaning for us in the close vicinity of where we live. It was not easy, it was not easy and now I know why...I did not know anything about my family history ...I do not remember if I had had any knowledge before at all? I do not know why I did not ask about that kind of information from my family. Wasn't I mature enough to value that knowledge or did my grandparents think their life had not been worth talking about? Knowing nothing about the past of my family, I did not feel any link with the place of my birth except the sentiment toward my childhood. The genealogical family tree constructed in the secondary school collected only the dates and was completely dry in meaning for a teenager. (...)

\section{Episode 2: Looking for I, Me and Myself}

The first time I felt I have my own past was in 2003 when I moved with my husband and our four-year-old son to London. In such a melting pot, among a mixture of cultures I started to be able to characterise myself ... I also felt the need and responsibility to help my child to look for and create his own identity (...). Moving to London was the beginning of the process of developing my need to come back and starting to become interested in my own culture. Straight after coming back I was actively involved in a local association in the community of one thousand inhabitants where I was born. Suddenly I understood that such a small community is so rich in treasured memory. It is in those memories I need to find myself.

\section{Episode 3: Ask your Grandma, Ask your Grandma...}

Now I am living in a village, near the small town of 36,000 inhabitants. Before my moving abroad I used to think about that village that it is just a small place in the middle of nowhere. In my childhood the only information I acquired about my region was from the weather forecast that used to show my place as one of those with the higher temperatures in the country. After coming back from London I became a very active person in community life. I inspire the locals to participate in different local projects. I really care about my personal knowledge about this place as well as of the development of a consciousness of myself and of the local people. We are looking together for the hidden facts, episodes, and memories. One of our own projects was “Our village treasure'. We all of us have been reaching down to the roots of our identities, but the most striking for me was when the oldest people I conducted interviews with repeated to me many times 'Ask your grandma, ask your grandma, why don't you ask your grandma?'... That was really like a cold shower for my mind. Why was I so deaf and blind for so long? I do not understand.

Monika starts talking using the plural, which is typical for the narrators from D community, but was not used in communities A, B, or C. However, the moment 
she looks for causes, she switches to the singular and starts blaming herself for not having any knowledge of her family/local past. She speaks about herself but she seems to take the responsibility for all the others of her age in community D. Speaking about herself, she is probably introducing a local state of consciousness toward the local/family past and individual and collective identity. That reflection could have been the turning point in the process of constructing her identity, but it was not in fact. It was only 'like awakening from a long sleep' (Monika). The last episode from Monika's talk confirms her as a person who has successfully managed to separate herself from her past, which is empty of meaning, and become ready for reflexive analysis to empower the process of individual self-identification. The collection of facts about local family histories which Monika and her association have started is treated as a "local treasure' that supports the process of recreating and re-shaping their community identity. The process of symbolic closing of these 'spaces of local memory' seems to be finished for Monika. She has found her own "key' to activate herself in giving meaning to local practices through the process of reflective and critical thinking about her former modus vivendi in her community. In her reflexive story she shows her own way of following the pattern: Concerns Projects - Practices.

\section{CONCLUSION}

The people of the three local communities located in close proximity to one another have very different attitudes toward their local development and towards opening up new learning spaces. They are also at different stages in the process of closing their private symbolic spaces in their local communities. Their attitudes to the local space depend on locally constructed meanings of the community which can be the result of different biographical experiences. People in all three communities showed that they depend on the quality of other social interactions - such as the involvement of significant others, the involvement of formal and non-formal leaders - for the creation of their symbolic spaces. In this way the local significant others unconsciously intensify the positive feedback which is also expected from the local government. That power which is mutually directed to the three angles of the imagined triangle can cause the synergy effect between their active agents. Alternatively, the weakness of one side of the triangle weakens the other two.

People in community A unconsciously or consciously stress the negative features of their living place. They probably do not realise that their discourse, by passing from one mouth to another, strengthens the negative picture of their place of residence. In that way they weaken the positive emotional attitude toward the place. That influences the other two sides of the triangle and fixes a process of disintegration instead of integration. The process of symbolic closing of their space is not as advanced as in community B or C.

On the contrary, in community B people have created their own almost idealistic strategy for local development. They are the example of creating positive symbolic 
status and promoting the uniqueness of their place. They are in a process of closing their symbolic space and projecting new activities for the future. All three sides of the triangle sketched in above cooperate with one another and the people acquire this way as a habitual local strategy which brings more profits than just managing the losses.

People in community $\mathrm{C}$, on the other hand, struggle against domination by local politicians, who in turn do not support either individual concerns of local actors or do not contribute to local symbolic space. The priority for Community $\mathrm{C}$ is probably symbolic cohesion, which in turn could create a positive attitude toward their place and in a foreseeable future would allow them to start the process of symbolic closing of the local space. According to our data, the general impression is that the people in community $\mathrm{C}$ have the potential in all three directions but they are perhaps not ready for mutual cooperation.

In community $\mathrm{D}$, where Monika comes from, the positive attitude toward the future has been embedded in the reconstruction of the past to elicit the 'treasure' of identity hidden in locals' minds, memories, and life experiences. The empowerment to look for a local collective identity seems to be born when 'I' starts to be "we' and then in reflexive processes seems to collect the local wisdom that empowered people to look for the new 'substance' in creating new local/community bonds through active participation in a community life and local reflexivity.

\section{NOTES}

11989 marks the end of the cold war period for Poland, with the end of one-party-rule by the Polish Communist Party and the introduction of a market economy and political reform.

2 At the time of writing the crisis in Ukraine, which broke out in the winter of 2013-2014 and has developed into a limited civil war within the confines of Eastern Ukraine, has thrown the normalization efforts of the past into a new, and uncertain, light.

\section{REFERENCES}

Archer, M. S. (2007). The trajectory of the morphogenetic approach. Sociologia, Problemas e Practicas, 54, 35-47. Retrieved October 20, 2010, from http://docs.google.com//www.scielo.oces.-mctes.pt/pdf/ $\mathrm{spp} / \mathrm{n} 54 / \mathrm{n} 54 \mathrm{a} 03$

Archer, M. S. (2010, October). How does the social order influence human agency? Hydraulics, routine or reflexivity. Unpublished Lecture presented at the Conference "Social Agency", Wroclaw.

Collins, R. (2005). Interaction ritual chains. Princeton, NJ \& Oxford, England: Princeton University Press.

Denzin, N. K., \& Lincoln, Y. S. (2009). Metody badań jakościowych. Warszawa, Poland: Wydawnictwo Naukowe PWN.

Jałowiecki, B., \& Szczepański, M. S. (Eds.). (2002). Miasto i przestrzeń w perspektywie socjologicznej. Warszawa, Poland: Wydawnictwo Naukowe Scholar.

Kurantowicz, E. (2011). Micro-development: Among localization, de-localisation and re-localisation processes in the perspective of polish social and political transformations. In A. Fragoso, E. Kurantowicz, \& E. Lucio-Villegas (Eds.), Between global and local: Adult learning and development. Frankfurt am Main, Germany: Peter Lang. 
Kwiatkowski, S. M., Michalak, J. M., \& Nowosad, I. (2011). Przywództwo edukacyjne w szkole i jej otoczeniu. Warszawa, Poland: Diffin SA.

Malewska-Szałygin, A. (2002). Wiedza potoczna o sprawach publicznych. Warszawa, Poland: Wydawnictwo DiG.

Miles, M. B., \& Huberman, A. M. (2000). Analiza danych jakościowych. Białystok, Poland: TransHumana.

Ligus, R. (2009). Twenty years of living a life in a suburban community. In R. Evans (Ed.), Between global and local. Local development. Community and adult learning-Learning landscapes between the mainstream and the margins. Duisburg, Germany: Nisaba verlag.

Ligus, R. (2013). Identity and dignity in narrative biographical episodes of contemporary polish "nonmigrants'. In M. Kafar \& M. Modrzejewska-Świgulska (Eds.), Autobiography-biography-narration. Research practice for biographical perspectives. Łódź-Kraków, Poland: Jagiellonian University Press.

Łukowski, W. (2002). Spoleczne tworzenie ojczyzn. Warszawa, Poland: Wydawnictwo Naukowe Scholar.

Łukowski, W. (2009). Symboliczne domykanie społeczności lokalnych i regionalnych w późnonowczenej przestrzeni społecznej. Przykłady z Mazur. In G. Gorzelak, M. S. Szczepański, \& W. Ślęzak-Tazbir (Eds.), Człowiek-miasto-region: Zwiazki i interakcje. Warszawa, Poland: Wydawnictwo Naukowe Scholar.

Staniszkis, J. (2001). Poskomunizm: Próba opisu. Gdańsk, Poland: Wydawnictwo. Retrieved from słowo/ obraz/terytoria

Tett, L. (2010). Community education, learning and development (3rd ed.). Edinburgh, Scotland: Dunedin Academic Press.

Traba, R., \& Sakson, A. (Eds.). (2007). Przeszłość zapamiętana: Narracje z pogranicza. Olsztyn, Poland: Borussia.

Zagórski, K. (Ed.). (2009). Życie po zmianie: Warunki życia i satysfakcje Polaków. Warszawa, Poland: Wydawnictwo Naukowe SCHOLAR.

Zieliński, E. (2001). Nauka o państwie i polityce. Warszawa, Poland: Dom Wydawniczy Elipsa.

\section{Rozalia Ligus}

Director of the Jewish School Szalom Alejchem

Wroctaw, Poland 



\title{
5. THE RESULTS OF LOCAL COMMUNITY PROJECTS
}

\author{
Political and Research Contexts
}

The political transformations of 1989 and the accession of Poland to the European Union had a significant impact on the socio-economic conditions of local communities in Poland. The increasing significance of the globalization phenomenon caused various processes - some of them initially perceived as contradictory processes to emerge which, as Zygmunt Bauman (2006) argues, led social reality to become ambiguous and fluid. The following processes, which may be characterized as ambiguous and, in some cases, seemingly contradictory, had significant impacts on the development of Polish local communities:

- formal decentralization of some of the areas of social life and the granting of selfgovernance privileges to local communities (Antkowiak, 2011),

- simultaneous quasi-formal centralization of power at the European Union level (Flejterski \& Zioło, 2008),

- world financial crises and breakdowns (of 2008 and the following years) and the dominant position of the economy based on neoliberal or "post-neoliberal" assumptions (Saad-Filho \& Johnston, 2009),

- growing social inequality and social polarization (Krajewska, 2011),

- overt belief in socio-cultural unification and simultaneous processes of differentiation among communities underlining the importance of local identities (Appadurai, 2008).

The processes listed above caused Polish local communities, in a similar way to communities in other countries, to be directly subjected to the imperatives: "what is local?" and "what is global?" This means that local communities are situated 'between' global socio-cultural and economic processes and local social and socioeconomic circumstances. The sole fact of an individual or a local community being a subject of transnational and international actions indicates the "politicization" and "internationalization" of social life (Giddens, 2007).

Immanuel Wallerstein (2007), together with other scholars who contributed to the development of the world-system theory, emphasizes that the post-socialist states constitute, within the capitalistic world-system, the so-called semi-periphery or the so-called second world (Starnawski \& Wielgosz, 2007), distant from the centres where the concentration and movement of capital is greatest (the so-called category 
of 'centres' includes among others: the USA, Great Britain, South Africa, China). Reference to the world-system theory helps to emphasize that those local communities which already constitute peripheries within their own country face particularly tough conditions in striving for an inclusive and balanced development. In the case of such communities we can speak of a 'double' exclusion and of 'doubly' reduced chances for a rapid and balanced development, such as that which was expected during the period of political transformation in Poland (Żuk, 2008). Despite the considerable significance assigned to local initiatives for social development and social cohesion by neoliberal discourse, Poland's experience includes increasing centralization, growing importance of the big urban centres, decreasing importance of the country's 'peripheries' (Stasieniuk, 2004), and the consequent increase in social inequality, including its geographical aspect.

The 'doubleness', mentioned above, means that some local communities (in the global context), already suffer at a level of global analysis from impeded development since they do not attract the attention of global capital. These conditions further deteriorate when Poland's internal regional diversity, including its own division into centres vs peripheries, is considered. Hence it may be argued that local communities, located within a country's peripheries face the above-mentioned 'double' difficulties in reaching balanced and stable development. Typically, this affects communities which struggle with social problems like high unemployment rates, poverty, low socio-cultural capital, depopulation caused by economic migration, and others. Many support programmes which are financed by various entities, including the European Union, are directed towards such communities. Today the growing importance of the European Union for the shape and scope of social cohesion policies is an unquestioned fact, regarding both the economy (i.e., the growing importance of financing small and medium-size enterprises) and the broadly defined European social policy (Rutkiewicz, 2014).

This chapter aims to point out some difficulties that accompany attempts to evaluate the effectiveness of various forms of support for individuals and local communities, especially those which focus on labor market re-entry action plans in general without considering local factors like local labour market specifics. Another aim of this chapter is to demonstrate the variety of dimensions and perspectives that should be considered when developing this kind of support programme for local lives, and also the clear necessity for conducting research to achieve a better understanding of their contexts and effects. Conclusions presented in this chapter have been reached through detailed literature analysis and by conducting interviews with individuals who are involved in the implementation of labor market re-entry action plans and various support projects for the members of local communities. Interviews were conducted with project managers, social workers and career counsellors who have been involved in the implementation of different projects, mostly financed by the European Social Fund. The research was conducted in the years 2009-2014 and mostly constituted open interviews. Students of the University of Lower Silesia joined the project team, bringing to its work their local perspectives and their ability 
to select and approach people who were responsible for implementation of projects on the ground in particular local communities. The first part of this chapter will demonstrate the different perspectives of our analysis.

\section{INDIVIDUAL PERSPECTIVE VS LOCAL COMMUNITY PERSPECTIVE?}

A first conclusion that followed on from our analytical approach was the fact that even if a particular project/support program helped to achieve positive results for individuals, it did not necessarily lead to positive results for the local communities. One of our interlocutors pointed out that as a result of the local labour market reentry action plan, many of the participants improved their individual life quality by choosing economic migration abroad or to larger urban centers. It is clear that such results may seem attractive for particular individuals, but local communities suffer impeded development as an effect of depopulation and the 'draining' of the local social capital. The need for social capital for the development of local communities has been emphasized by many (Fukuyama, 1997; Szczepański, 2000).

The question of the relationship between the individual and the community has long been described and debated by representatives of various academic disciplines (structuralism, functionalism, constructionism, etc.) without reaching any conclusive results (Benton \& Craib, 2003). Although it does not seem questionable that the effectiveness of local community support programs cannot be simply brought down to what impact they have on the socio-economic situation of particular members of that community, improving life conditions of individuals does not necessarily have a positive influence on the local community. Adopting such a view may contribute to an increasing risk of the so-called reversal effect occurring, a phenomenon described by Boudon (2008), which causes opposite effects to occur to those expected.

Another issue touches on culture and the broad understanding of individualization processes. There is no doubt that contemporary culture is dominated by the principle of individualism, and self-actualization is today one of the top life priorities (Jacyno, 2007). In such a culture, community values tend to be 'forgotten' (Potulicka \& Rutkowiak, 2010). Szacki (1997) argues for their importance, stressing that they constitute an essential requirement for the development of a civil society. Mentioning this dimension of an individualism-dominated culture serves as a reminder that, besides its obvious positive aspects and consequences, it brings with itself certain threats, including some that may have a certain impact on the development and implementation of programmes and projects designed for local communities. Three potential difficulties can be identified:

- a strong sense of individualism adopted by community members may decrease individuals' willingness to participate in joint civic activities and therefore impedes communal actions,

- Potulicka (2010) argues that from a critical perspective an adopted internalised sense of individualism may serve as a 'convenient' ideology characterized by 
lack of actions tending to benefit the whole local community. The idea which assumes that an individual is fully responsible for their own life may result in the occurrence of the mechanisms described by the "flawed character theory" (Boczoń, Toczyński, \& Zielińska, 2003) - transferring the responsibility for failures onto an individual or, in case of a local community, onto local authorities and leaders,

- programmes and projects based on individualistic principles often focus on individual support e.g. educational or vocational support, however, Johnston (2009) emphasizes that such initiatives are necessary but not sufficient for fulfilling other social functions (e.g., combating poverty or socio-cultural animation). Johnston stresses further that investing in skills acquisition may not bring the desired results if a local environment is not able to offer employment or self-employment opportunities.

Summarizing the reflections on the two different perspectives for analyzing project activities in local communities, the authors of this chapter would like to underline that the analyses conducted were not done by uncritically adopting certain structuralist or functionalist perspectives. The interpretations presented here are mainly inspired by the theories of authors such as Bourdieu (1990), Giddens (2003), and Habermas (1985). Based on their work a conclusion may be drawn that in projects intended for local communities both individual and social dimensions have to be included. Therefore the perspective to be adopted - the individual vs the local community - remains in need of further studies in the context of activities undertaken on the behalf of local communities.

\section{DECENTRALIZATION VS CENTRALIZATION?}

The interview interlocutors often signalized a common problem that would occur during the implementation of a mobilization project in a local community, namely the inadequacy of proposed actions and solutions to a local community's needs and conditions, for example, for the local labour market. The aims and character of such actions are often set at the European Union level, although the elaboration of more detailed procedures is often ceded to more local (in the European context) entities such as Regional Labour Offices. Considering the division, mentioned earlier in this chapter, of countries into 'core-countries' and 'semi-peripheral-countries' and the internal diversities of particular states, it becomes clear that the needs of local communities differ greatly and the projects' aims, defined at European Union level, do not always respond properly to such different needs. As an example one may refer to the European Union's emphasis on educating people in professions connected to care of the elderly. Projects launched and implemented in that area did not have a major impact on the Polish labour market, in the form of a massive boost in employment, since most of the local labour markets do not offer many employment possibilities in this sector, due to, among other factors, a lack of professional 
institutions which could specialize in elderly care, a reason for which is that Polish culture does not encourage using the services of such institutions.

On the other hand one has to realize that, as many studies of centralization and decentralization processes have indicated (Flejterski \& Zioło, 2008), adoption of a complete decentralization model, in different areas of social life, would result in a new set of problems, in that, as Meijers (2002) puts it, "older problems are replaced by a set of new ones". Among the "new" problems, the following issues may become prominent: problems concerning quality control, the lack of balanced development of different regions, difficulties in managing policies for cohesive development. Therefore it seems to be clear that further studies are necessary to find the right understanding of how to shape the European Union's policies and develop programs and projects intended for local communities. Social animation theorists and professionals agree that emphasis on a proper analysis of local needs is the key element of any successful social animation actions intended to benefit a local community (Dutkiewicz, Kazimierczak, Rybka, \& Rymsza, 2008). That is why analyzing the way the aims and desired results of the European Union's projects for local communities and its members are being set, may contribute to gaining a better understanding of its effects and mechanisms.

\section{SOCIO-NORMATIVE ORDER VS UNCERTAIN REALITY?}

Wódz (2008, p. 70) writes: "various sociological studies confirm that on a local level (...) some sense of 'longing' may be observed (...) 'longing' for a stable sense of normative certainty and also that the local level is characterized by permanent elements of an ongoing socio-normative order". The author argues further that local institutions in local communities play not only a political role but also a specific one as a guardian of a socio-normative order, which is not the case with institutions at regional, national, or international levels.

The argument presented by Wódz, which as its author emphasizes is based on empirical research, may serve as a counterpoint to the opinions of the social workers and labor office career counsellors involved in implementing mobility projects in local communities who took part in the interviews. Interlocutors repeatedly brought to light two issues related to the projects implemented:

- a discrepancy between the aims of the projects and of the local institutions' aims (e.g. the urgent necessity specified in the project of a swift re-entrance to the labour market of individuals who are not yet ready to take up employment and who still require long-term support),

- the necessity to change social image and operating methods (e.g. implementation of the Active Social Policy; the necessity for some public institutions to undertake for profit activities despite their traditionally different roles).

It becomes clear that some of the projects financed by the European Union do not take into account the local role of social institutions, for example, expecting local 
institutions to promote values/norms which are not commonly accepted in particular communities. Changes in the functional and financial aspects of local institutions related to the implementation of various projects often cause anxiety and uncertainty about the future among the employees.

Another problem, associated with the institutional dimension, can be defined as 'simulated actions in the field of civic activity', which may be understood as reducing social capital development in local communities to solely institutional dimensions (creating the legal and organizational conditions for non-governmental organization activity without strengthening and encouraging civic participation and engagement). Projects are often implemented by institutions which lack trust in the local community, which discourages the participation of community members.

It appears that an understanding of the social (local) role of the institutions responsible for the implementation of projects is another issue in which further studies may help to improve the development of local communities. Therefore those institutions may constitute another study object for analyzing effects and mechanisms of carrying out EU projects in local communities.

\section{SUMMARY}

The aim of this chapter was to point out political (local and global) dimensions and perspectives for the analysis not only of the effectiveness, but also of the implementation methods of EU projects, that aim to improve the development of local communities. Challenges for researchers, evaluators, and diagnosticians of such activities were also outlined in this chapter.

The authors of this chapter are aware that conducting critical analyses of the effects and implementation methods of EU projects in local communities may trigger a question: why is it worth carrying out such EU-financed activities? However, the authors believe that there is a different question that needs to be asked: how to construct and carry out projects to assure that desired aims and tasks are fulfilled not only from the individual perspective but also from the local community perspective? Equally important is the "reverse" side of this relation and the following question: how to construct and carry out projects to insure that the desired aims and tasks are fulfilled not only from the local community perspective but also from the individual perspective? By asking these kinds of questions we wish to emphasize, following Giddens (2003), the 'internal referentiality' of the relations between individual and local community.

Thus, the crucial issues that should be carefully examined and taken into account include the following:

- enabling development of the educational dimension of a local community: "community as politics" (participation model) through appropriate local policies (Shaw \& Martin, 2000), 
- recognizing the experience (knowledge) of a local community and constructing programs and projects based on that (Johnston, 2003),

- finding a way to extend social capital development from a solely institutional dimension - which creates the formal legal and organisational conditions for NGO activity without however really encouraging the participation of civil society - by creating mechanisms for strengthening and encouraging civic participation and engagement.

\section{REFERENCES}

Antkowiak, P. (2011). Decentralizacja władzy publicznej w Polsce na przykładzie samorządu terytorialnego. Środkowoeuropejskie Studia Polityczne, 2, 155-174.

Appadurai, A. (2008). Nowoczesność bez granic, Kulturowe wymiary globalizacji. Kraków, Poland: Towarzystwo Autorów i Wydawców Prac Naukowych UNIVERSITAS.

Bauman, Z. (2006). Plynna nowoczesność. Kraków, Poland: Wydawnictwo Literackie.

Benton, T., \& Craib, I. (2003). Filozofia nauk społecznych: Od pozytywizmu do postmodernizmu. Wrocław, Poland: Wydawnictwo Dolnośląskiej Szkoły Wyższej Edukacji TWP.

Boczoń, J., Toczyński, W., \& Zielińska, A. (2003). Ubóstwo jako zjawisko społeczne oraz przedmiot pracy socjalnej. In T. Pilch \& I. Lepalczyk (Eds.), Pedagogika społeczna. Warszawa, Poland: Wydawnictwo Akademickie ŻAK.

Boudon, R. (2007). Efekt odwrócenia: Niezamierzone skutki działań społecznych. Warszawa, Poland: Oficyna Naukowa.

Bourdieu, P. (1990). The logic of practice. Cambridge, England: Polity Press.

Dudkiewicz, M., Kazimierczak, T., Rybka, I., \& Rymsza, M. (2008). Animacja lokalna: Jak aktywizować społeczność wiejska. Z doświadczeń projektu "W stronę polskiego modelu gospodarki społecznej budujemy nowy Lisków". Warszawa, Poland: Instytut Spraw Publicznych.

Flejterski, S., \& Zioło, M. (2008). Centralizacja i decentralizacja zadań publicznych w świetle wybranych rozwiązań europejskich. Próba oceny. Studia Regionalne i Lokalne, 3(33), 76-94.

Fukuyama, F. (1997). Zaufanie: Kapitat spoteczny a droga dodobrobytu. Warszawa, Wrocław, Poland: PWN.

Giddens, A. (2003). Stanowienia społeczeństwa: Zarys teorii strukturacji (S. Amsterdamski, Trans.). Poznań, Poland: Wydawnictwo Zysk i S-ka.

Giddens, A. (2007). Nowoczesność i tożsamość: "Ja” i społeczeństwo w epoce późnej nowoczesności. Warszawa, Poland: Wydawnictwo Naukowe PWN.

Habermas, J. (1985). The theory of communicative action: Lifeworld and system: A critique of functionalist reason (Vol. 2, Thomas McCarthy, Trans.). Boston, MA: Beacon Press.

Jacyno, M. (2007). Kultura indywidualizmu. Warszawa, Poland: Wydawnictwo Naukowe PWN.

Johnston, D. (2009). Ubóstwo i dystrybucja - znów w polu zainteresowań neoliberałów. In A. Saad-Filho \& D. Johnston (Eds.), Neoliberalizm przed trybunałem: Wybór tekstów krytycznych. Warszawa, Poland: Instytut Wydawniczy Książka i Prasa.

Johnston, R. (2003). Adult learning and citizenship: Clearing the ground. In P. Coare \& R. Johnston (Eds.), Adult learning, citizenship and community voices: Exploring community-based practices. Leicester, England: NIACE.

Krajewska, A. (2011). Wzrost zróżnicowania dochodów - ujemna strona transformacji polskiej gospodarki. Zeszyty Naukowe, 9, 159-178.

Meijers, F. (2002). Career policy for the contemporary world: Dictat or stimulant? Cambridge, England: The Career-Learning Network.

Potulicka, E. (2010). Pytania o skutki neoliberalizmu. Aspekt społeczny. In E. Potulicka \& J. Rutkowiak (Eds.), Neoliberalne uwikłania edukacji. Kraków, Poland: Oficyna Wydawnicza Impuls.

Potulicka, E., \& Rutkowiak, J. (2010). Neoliberalne uwikłania edukacji. Kraków, Poland: Oficyna Wydawnicza "Impuls". 
Rutkiewicz, K. (2014). Znaczenie Funduszy Europejskich dla rozwoju gospodarczego Polski. Retrieved October 17, 2014, from www.bibiliotekacyfrowa.pl/content/37116/08_Krzysztof_Rutkiewicz.pdf

Saad-Filho, A., \& Johnston, D. (Eds.). (2009). Neoliberalizm przed trybunatem. Wybór tekstów krytycznych. Warszawa, Poland: Książka i Prasa.

Shaw, M., \& Martin, I. (2000). Community work, citizenship and democracy: Remaking the connections. Community Development Journal, 35(4), 401-413.

Starnawski, M., \& Wielgosz, P. (2007). Kapitalizm nad przepaścią, społeczeństwa wobec wyboru. Wstęp (Preface). In I. Wallerstein, Analiza systemów-światów. Wprowadzenie. Warszawa, Poland: Wydawnictwo Akademickie Dialog.

Stasieniuk, Ż. (2004). Centralizm i regionalizm jako czynniki różnicowania zbiorowości społecznych. Nierówności Spoleczne a Wzrost Gospodarczy, 4, 121-128.

Szacki, J. (1997). Ani ksiązę, ani kupiec: obywatel. Idea spoleczeństwa obywatelskiego w myśli wspótczesnej: Wybór tekstów. Warszawa, Kraków, Poland: Fundacja im. Stefana Batorego, Wydawnictwo ZNAK.

Szczepański, M. (2000). Kapitat społeczno-kulturowy a rozwój lokalny i regionalny. Tychy, Poland: Śląskie Wydawnictwa Naukowe, Wyższa Szkoła Zarządzania i Nauk Społecznych w Tychach.

Wallerstein, I. (2007). Analiza systemów-światów: Wprowadzenie. Warszawa, Poland: Wydawnictwo Akademickie Dialog.

Wódz, J. (2008). Czy stabilny ład społeczno-normatywny to utopia? In P. Żuk (Ed.), Spotkania z utopia w XXI wieku. Warszawa, Poland: Oficyna Naukowa i Instytut Problemów Europejskich.

Żuk, P. (2008). Wstęp (Preface). In P. Żuk (Ed.), Spotkania z utopia w XXI wieku. Warszawa, Poland: Oficyna Naukowa i Instytut Problemów Europejskich.

\section{Anna Bilon}

University of Lower Silesia

Wroctaw, Poland

Ewa Kurantowicz

University of Lower Silesia

Wroctaw, Poland 
SECTION II

ADULT LEARNING AND COMMUNITIES 



\title{
PYOLLIM HONG AND JIM CROWTHER
}

\section{LEARNING CITIZENSHIP IN THE COMMUNITY}

\author{
Young Adults, Participation and Democracy
}

This chapter focuses on young adults' experiences of learning citizenship in the community. This is particularly pertinent in Scotland today as young adults 16 and 17 years old will be allowed to vote for the first time in Scottish elections (although not in UK national elections). ${ }^{1}$ However, it is not the specifics of young adults and the right to vote that we address in this chapter but the broader one of learning citizenship and democracy. Biesta (2011) argues that we all need more opportunities to practise democracy rather than being taught to be citizens. Whilst we agree with this, it is also the case that democracy is contested and what is practised in its name needs to be engaged with critically. In other words, the politics of learning citizenship through participation in community activities can lead to very different views of democracy.

The chapter will focus on how community, participation and citizenship are constructed in ways which emphasise social capital (i.e., relationships and service work in communities) and political capital (i.e., knowledge of formal political processes and procedures). Increasingly, however, learning citizenship in policy focuses on what can be termed a neoliberal version of citizenship (and democracy) which prioritises economic participation i.e. that young adults have to acquire the knowledge, experience and skills to get on and get into the labour market through their own efforts. This focus on their economic future also preoccupies young people who are in that transitional stage of leaving school and facing the problem of a collapse of employment opportunities. At the same time, this development serves to encourage a depoliticised and individualised version of citizenship rather than one that is concerned with the collective needs and interests of the wider community and society. Participation in formal political processes and procedures, where democracy is practised, is an arena which young people feel marginal to and marginalised from through the exclusion of their interests and concerns. They are, nevertheless, interested in and engaged by a wide range of social, cultural and environmental issues often at the micro level of personal and community activity rather than at the macro level of collective activism.

One of the claims made for the distinctive nature of community education is its freedom from formal educational structures and concerns. A central axiom of community education is 'working where people are at' in the sense of meeting 
people on their own territory as well as engaging them educationally around their own expressed concerns and interests. This so-called 'free' space of community is increasingly difficult to maintain, however, as it becomes an alternative site for more formal educational purposes and practices. A creeping colonization process is evident in the area of citizenship education. Community has become a crucial resource for doing citizenship education in recent policy making in Scotland. It is claimed that community as relevant "real-life contexts" not only provides an essential means to "democratic and participative methodologies to learning" it can also reshape the agency of young people as "citizens now, not in waiting" by recognising their contribution to resolving social issues of the local community and the wider society (Learning Teaching Scotland, 2011, p. 13). Yet this seems out-ofstep with the way in which a neoliberal version of citizenship is becoming dominant. Despite the seemingly progressive rhetoric of learning citizenship the direction of travel is towards ensuring that young people are more engaged in struggles in the labour market rather than struggles in community and society. Having said that, the interest of young people in direct activism still provides an opportunity for critical educational practice.

\section{COMMUNITY AND CITIZENSHIP EDUCATION}

Community education in Scotland is associated historically with aspirations for democracy, social justice, equality and an informal, learner-centred pedagogical approach (see Tett, 2010). In this regard, community education can be seen as an essential reservoir of democratic citizenship education and engagement. In reality achieving these outcomes can be a challenging task. On the one hand, 'community' is an ambiguous idea which can be used for a variety of conflicting and contested purposes. As Shaw (2008) emphasises, "the politics of community" must be scrutinised because community is "a political category in itself... [which] reflects and reinforces the dynamics of power within particular contexts and times" (2008, p. 34). For her, the recognition of the politics of community mirrors not merely a problematic reality of 'the world as it is', in the process reinforcing existing unequal and divisive social relations of power, but also promising social change through ways to create a more equal, supportive and sustainable alterative - 'the world as it could be' (Shaw, 2008, p. 34). Other authors such as Fyfe (2010), Coburn and Wallace (2011) translate youth-related work into the politics of community, critically assessing a dominant, less-controversial discourse of 'deficit' in which young people are socialised into pre-defined values and norms of the community and a more radical but, in practice, often compromised discourse of youth as 'active citizens' in which young people participate in society as equal citizens and capable social and political agents.

Whilst we align ourselves with the view that young adults are equal citizens we want to go further than suggesting this discourse is compromised in practice. In fact, it seems in many respects to be increasingly incorporated into the neo-liberal, market-driven reform in community education, which has resulted in the gradual 
erosion of practitioners' commitment to more radical education (Craig, 1989; Henderson \& Glen, 2005; Tett et al., 2007). Instead, "community workers are often called on by government to contribute to the peaceful management of the process of economic change...to help people adjust to the insecurity and fragmentation of their lives" rather than being agents of social change (see Craig, cited in Shaw, 2008, p. 13). In other words, social cohesion and inclusion in the economic order trumps the democratic participation of young people in policy and, increasingly, in community education practice. We outline below - in the section on frameworks for analysis differing ways of conceptualising citizenship education in the context of community education. Before going into this detail, however, we will briefly introduce the methodology and community context of the study.

\section{METHODOLOGY}

The approach to the study was a qualitative one involving a series of semistructured interviews with a small sample of respondents; two community educators (pseudonyms of Sophie \& Alex) and 10 young people (all with pseudonyms). ${ }^{2}$ The study was interested in their experiences and attitudes towards teaching and learning citizenship outside of school. The young people were selected and contacted through their participation in a range of community projects. We do not claim this sample is representative in any way of young adults but that the interview material can provide insights into the attitudes, experiences and meaning of citizenship learning and teaching in the 'community'.

Eight out of ten young adults were involved in youth participation programmes, organised by the local state. The project embodied a number of different communitybased educational programmes concerned with electoral promotion, Learning for Democracy courses, Student School Council training, a Youth Congress and support for members of Scottish Youth Parliament. Eight young people were members of the Youth Congress: a fully constituted voluntary organisation for local young people where two representatives from secondary schools share and discuss issues relating to the lives of young people in the community. The membership of the Congress usually included $10-12$ regular members and 2-4 irregular or new comers. The Congress seemed to offer a unique opportunity for young people to participate in political processes by being in direct contact with the local 'stakeholders' including state officials, local Scottish Members of Parliament, pressure groups and other youth organisations.

It is important to note that along with the involvement in the Congress and other community-based education for citizenship, all young people were also participating in civic/voluntary projects and activities in their local communities. Two more interviewees were recruited as a result of their active involvement in various charity and voluntary works in the community.

The two community educators were purposefully selected because of their 'track record' of working with young people on issues of citizenship and democracy. 
The community education workers were long-term local state employees who had been involved in a variety of youth-focused community learning and development activity. Based on these rich, first-hand experiences with young people and local/ national youth agendas, the narratives of these community education workers will demonstrate how recent changes in economic, social, cultural and political circumstances have created opportunities, tension and dilemmas for their practice of informal citizenship education.

\section{THE COMMUNITY CONTEXT}

Data collection occurred in several different sites within a large area of West Lothian (Bathgate, Linlithgow, Livingston, \& West Calder), located in the central belt of Scotland. These communities are relatively small and rural compared to the nearby cities such as Edinburgh and Glasgow. The area has gone through radical changes in economic and social conditions as a result of the demise of traditional heavy industries such as coal mining and manufacturing and despite large policy intervention (e.g., Silicon Glen, Partnership Action for Continuing Employment, Livingston new town development). Issues of unemployment, redundancies, poverty have been consistent key economic and social issues in West Lothian (West Lothian Council, 2011a, 2011b, 2013). The unemployment rate for adults in March 2013 was 4.3\% which is higher than the Scottish national average of $4.1 \%$ and the UK rate of 3.8\% (West Lothian Economic Partnership, 2013). Youth unemployment (18-24-year-olds) is also higher than the national average $(9.1 \%$ and $7.6 \%$ respectively) and in regard to the fact that there has been "the biggest fall in 20 years" in youth unemployment "Scotland now has a lower headline (16+) unemployment rate and lower youth (16-24) unemployment rate than the UK as a whole" (Scottish Government, 2013).

These broad changes in wider economic and social conditions, and relevant policy-making, played a powerful role in shaping the understanding and engagement with the community by community educators and young people.

\section{FRAMEWORK FOR ANALYSIS}

To ensure a rigorous comparison of different views on citizenship education amongst educators and young people we compiled a 4 dimensional framework from relevant literature drawing on existing citizenship education models (e.g., Kerr et al., 2004; Westheimer \& Kahne, 2004; Deuchar, 2007; Lister, 2007; Painter, 2008; Ross, Munn, \& Brown, 2007; Mayo, Gaventa, \& Rooke, 2009; Crowther \& Martin, 2010). This is presented below:

The four aims of citizenship education are characterised as follows:

- Learning for membership: emphasises a 'good neighbourly' version of citizenship such as personal characteristics of helping out, belonging and nationalism/ patriotism; 
Table 1. A conceptual framework of citizenship education

\begin{tabular}{|c|c|c|c|c|}
\hline Aim & $\begin{array}{l}\text { Learning for } \\
\text { membership }\end{array}$ & $\begin{array}{l}\text { Learning for } \\
\text { entrepreneurial } \\
\text { citizenship }\end{array}$ & $\begin{array}{l}\text { Learning for } \\
\text { conventional } \\
\text { political } \\
\text { participation }\end{array}$ & $\begin{array}{l}\text { Learning for } \\
\text { activism }\end{array}$ \\
\hline $\begin{array}{l}\text { BEYOND THE } \\
\text { STATE (European, } \\
\text { transnational, } \\
\text { international, } \\
\text { global) }\end{array}$ & $\begin{array}{l}\text { European } \\
\text { citizenship; } \\
\text { cosmopolitan } \\
\text { citizenship; } \\
\text { global } \\
\text { citizenship }\end{array}$ & $\begin{array}{l}\text { Global market; } \\
\text { world trade }\end{array}$ & $\begin{array}{l}\text { European youth } \\
\text { parliament }\end{array}$ & $\begin{array}{l}\text { International \& } \\
\text { global issues; } \\
\text { economic crisis; } \\
\text { migration; } \\
\text { sustainable } \\
\text { development; } \\
\text { human rights }\end{array}$ \\
\hline $\begin{array}{l}\text { STATE-LEVEL } \\
\text { (government; } \\
\text { local authority; } \\
\text { educational } \\
\text { authority) }\end{array}$ & $\begin{array}{l}\text { National identity; } \\
\text { nationalism; } \\
\text { social capital }\end{array}$ & $\begin{array}{l}\text { Enterprise } \\
\text { education; } \\
\text { human capital; } \\
\text { welfare; wealth } \\
\text { creation; } \\
\text { employment; } \\
\text { apprenticeship }\end{array}$ & $\begin{array}{l}\text { Formal decision- } \\
\text { making (voting/ } \\
\text { election); } \\
\text { political party; } \\
\text { trade unions; } \\
\text { youth parliament }\end{array}$ & $\begin{array}{l}\text { Domestic issues } \\
\text { and policies; } \\
\text { social inclusion; } \\
\text { national youth } \\
\text { organisation }\end{array}$ \\
\hline $\begin{array}{l}\text { BELOW THE STATE } \\
\text { (family; school; } \\
\text { peer group; local } \\
\text { community) }\end{array}$ & $\begin{array}{l}\text { Shared values; } \\
\text { good personal } \\
\text { characteristics; } \\
\text { volunteering; } \\
\text { helping others in } \\
\text { needs }\end{array}$ & $\begin{array}{l}\text { Creativity; } \\
\text { leadership; } \\
\text { competitiveness; } \\
\text { volunteering; } \\
\text { accredited } \\
\text { learning } \\
\text { opportunities }\end{array}$ & $\begin{array}{l}\text { Pupil (student) } \\
\text { council; youth } \\
\text { forums }\end{array}$ & $\begin{array}{l}\text { Local issues: } \\
\text { tackling issues } \\
\text { in everyday } \\
\text { lives such as } \\
\text { discrimination } \\
\text { against young } \\
\text { people, non- } \\
\text { heterosexuality; } \\
\text { ethnicity }\end{array}$ \\
\hline
\end{tabular}

(Adapted from Kerr et al., 2004; Westheimer \& Kahne, 2004; Deuchar, 2007; Lister, 2007; Ross, Munn, \& Brown, 2007; Painter, 2008; Mayo, Gaventa, \& Rooke, 2009; Crowther \& Martin, 2010)

- Learningfor entrepreneurial citizenship: emphasises citizenship education's direct connection to work via creativity, employability, adaptability, competitiveness and leadership;

- Learning for conventional political participation: emphasises knowledge and skills for formal politics such as political parties, trade union and other interest groups and voting/elections; and Learning for activism: emphasises non-conventional political participation and direct activism to address issues of inequality and social injustice at local, national and global level.

Each of these aims was further divided into 3 multi-scalar levels, including:

- Below the state: family, school, peer group and local community;

- National (state) level: Government, local authority, educational agencies; 
- Beyond the state: European, transnational, supranational, international, global community.

As the analyses below will demonstrate there is a shift underway in the direction of community being used as a space for citizenship learning which is dominated by an entrepreneurial model of citizenship below the level of the state. This is not the only type of learning being promoted but it is increasingly what preoccupies policy makers and young people. At the same time, the rhetoric of community education workers' vocabularies emphasise a radical or social purpose learning for activism; a rhetoric that connects with young people primarily at a micro level of engagement rather than with a politicised version of activism that seeks to engage young people with the politics of the state or beyond.

\section{COMMUNITY EDUCATORS' PERSPECTIVE}

In the following section we deploy the conceptual framework as a means of organising and clarifying the attitudes and approaches to citizenship expressed by the two community educators.

\section{Learning for Membership}

I think good character is important. The whole point of the community education worker's role is to work in the community, to encourage good characters, to encourage involvement, to share each other's expertise, so it's a holistic point of view rather than segregated or shutting doors as if you don't need any of the others. (Sophie)

Learning for membership involves the emphasis on desirable personal characteristics and civic virtues of being a 'good neighbour' or member of society. This mirrors the idea of Putnam's (2000) social capital perspective, which emphasises the importance of civic participation in building trust between fellow citizens and collective capacity to build a good society. Communication and other interpersonal social skills were identified as core elements of relevant learning and pro-social activities such as charity works and volunteering were promoted as important aspects of membership.

The 'good neighbour' focus inevitably presupposes wider shared interests and values of 'the community' and what this involves in terms of adequate citizenship skills and attitudes for those who are part of it. Thus attempts at socialisation or integration involve a certain degree of compliance and consenting to the accepted and, potentially, unproblematised or unquestioned norms of the community. Clearly building social capital is important for all collective formations but it is also necessary to question who benefits? Who and what is included or excluded? The danger of an unproblematised version of the good community (which is not a view we are ascribing to Sophie or Alex), is that learning for membership can adopt a 
conventional deficit view of young people needing to be socialised into the existing social order. The social order itself is placed beyond question.

\section{Learning for Entrepreneurial Citizenship}

Their [the current government] priority is very much on getting people jobs. In the past we were given resources and directions to go out and develop courses on democracy and government but I don't think that would now happen. Yet, the biggest problem ever is going to be the vote [for Scottish independence] that people will have to make. This is going to happen and as a community education service, we might not be able to play a significant role in that. (Alex)

Increasingly, the attitudes and skills for entrepreneurial citizenship were being driven by policy, which is fundamentally shaping the boundaries of practice with young people. There has been a noticeable shift in policy discourse in the last ten years from 'democratic civic renewal' to 'economic (re-) development' and 'wealth creation' (Crowther \& Martin, 2010). The community education workers raised a general concern about this development, with its potential to undermine more important ends of education such as broader personal development, social action and political engagement to bring about a more democratic - more equal, just and inclusivesociety. Alex pointed to the local state's decision to discontinue his Student School Council training after ten years and the emphasis on more employability projects as being a classic example of this trend.

Nevertheless, the community education workers understood developing entrepreneurial citizenship as important for acquiring (a) skills: for employability, such as social/communicative and other transferrable skills; (b) attitudes: economic responsibilities, competitiveness, self-reliance, self-management and resilience. In reality the policy context meant that a vast majority of programme and projects these community education workers were incorporated into tended towards entrepreneurship and employability, rather than reflecting other models of citizenship education. In the current dismal economic conditions in which youth unemployment is at unprecedentedly high levels their response to young people and policy demands was perhaps not surprising. However, the problem is that this agenda invariably construes the problem of work as a defect of the individual rather than of the economic context of austerity and diminished opportunities for employment. In the context of citizenship it works towards a remoralization of young adults as potential employees in need of the appropriate skills and attitudes to get into work.

\section{Learning for Formal Political Participation}

They should participate in politics and the reason they should is because if they aren't paying taxes, one day they will, if they aren't 18, one day they will be, if they don't have right to vote...In fact, life is political; personal is political; political is personal; you can't separate these two. (Sophie) 
Most young people have nothing to do with democracy; [they think] it doesn't affect their lives; it's a waste of time; it's boring. (Alex)

From their own local surveys of young people many were indeed disinterested in, disengaged with and disconnected from formal politics and political activities; less than one in two of the young people who were eligible were registered to vote. Hence participation in formal decision-making of various kinds was regarded as a pivotal element of citizenship education. This goal largely resonated with the policy agenda of youth empowerment, embedded in the UNCRC's article 12 (UNICEF, 2011).

Voting was taken to represent the fundamental belief of political freedom, equality and the right of citizens to legitimise and maintain democratic rule. On the other hand, the emphasis was also linked to the 2014 referendum for Scottish independence. As a consequence of this development there was an enthusiasm expressed by the workers to equip young people with the knowledge to participate in formal political processes and particularly with a commitment to voting as a democratic right that needed to be used.

\section{Learning for Activism}

... it's our responsibility to make sure that young people are at least heard, sometimes young people's views and ideas are inappropriate and unworkable. They need to be told why it is the case and being engaged in this kind of pluralistic relationship is a key one. (Alex)

The community education workers strongly agreed that community engagement plays a pivotal role in revitalising youth activity whereby issues, interests and debates of young people become the central focal point to their learning and exercise of citizenship. From this viewpoint, teaching activism was about effectuating 'pluralism' as an inherent principle of democratic society. Alex's views on pluralism are somewhat similar to Ranciere's understanding of the logic of 'equality' which is fundamentally distinguished from that of 'inclusion' which aims at assimilating or 'including' the previously marginalised groups of people into the existing social order, rather than recognising them as 'equal' members of the society who have potential to create a new heterogeneous democratic society by challenging and transforming the existing system (Ranciere, 2003).

Despite their commitments to a radical ideological vision of their work, the community educators were also focussed on guiding or adjusting young people's 'inappropriate or unworkable' views, rather than potentially exploring what workable and appropriate might mean, which unintentionally could lead to colluding with, rather than challenging, the adult-dominant power paradigm.

To summarise, in many ways the community education workers' narratives resonated with what Coburn and Wallace (2011, pp. 13-15) label as the 'critical perspective' which emphasises: 
- Community-based educational engagement aims at social and political transformation;

- Young people as capable social and political actors;

- Curriculum reflects shared social and political interests of young people;

- Pedagogy is based on dialogue rather than transmission;

- Critical understanding is linked to young people's broader action and struggle for social change.

Nevertheless, this radical or social purpose perspective was often diverted or diluted in practice to take account of other dominant policy imperatives such as learning for membership (youth socialisation), learning for entrepreneurial citizenship (employability and self-development) and learning for formal participation (political literacy and formal decision-making processes). From this viewpoint, this gap between radical rhetoric but less radical practice is still a problem to be addressed.

\section{WHAT YOUNG PEOPLE DO AND SAY}

In the following section we outline the views, attitudes and experiences of young people using the same categories of citizenship learning as deployed with the community educators. Our aim is to outline areas of convergence and divergence in their positions in order to go on to discuss any implications.

\section{Learning for Membership}

Being an active member of community' ... just participate if someone comes to your door and ask you to do something. If community is having a fundraising, go along. Don't isolate yourself from the rest of the people. (Charlie)

When asked young people's description of a 'good citizen' was largely coterminous with what Westheimer and Kahne (2004) described as "personally-responsible citizen", referring to activities such as caring, helping, fundraising and volunteering. Various types of activities were identified in relation to good citizenship, ranging from 'social capital' (as in Putnam's terms) including participating in sports clubs, town fair arrangements, local development projects to more 'political capital' (as in Shugurensky's terms 2000) such as pupil council, youth congress and marches/ protests.

Most interviewees described their enjoyment of being part of many, diverse, activities through which they undergo both social experiences - in the vocabulary of social capital bonding, bridging and possibly linking with different groups of people in the local/national community — and political experiences such as involvement in spaces for deliberation. The variety of activities and opportunities for involvement in the community seem important for not only making the experiences fun and interesting, but also creating a more holistic spectrum of participation, connecting and stimulating potentially exclusive social and political activities. 
I am part of a rugby club in the local community. It soon starts a tour and I am quite involved such as a fundraising... I am quite involved in organising events; speaking to different people; reaching out different communities. I thought it was really successful; I really enjoyed doing that. Another area that I am involved in the community and it's a way of getting to know the players; older members who don't play anymore and it's a good way of knowing people in the area. (Joe)

A concept of community was pivotal in the young people's articulation of the 'good citizen' not only as a physical site where a good citizen is a member and carries out his/her rights and responsibilities, but also in terms of what Benedict Anderson (1991) refers to as "imagined community" where a sense of belonging is stretched to the interconnected, interdependent 'people' of the community. This viewpoint stresses the good citizen as one who possesses an ethic of caring and neighbourliness.

However, learning citizenship through community activity was also done for personal advantage too. The instrumental reference (italicised) in the quote below should be kept in mind.

The congress and that kind of thing - showing that active involved citizen is a good way to get involved rather than being someone who is just there. 'Being active', obviously the universities are looking for that in people; obviously doing well in your exams are important; surely, you can work and you can have hard work ethic and having that experience in the Congress and others and showing the experiences and being confident talking to different people; you are able to function properly as a person, as a good citizen. (Joe)

This potential for involvement in community life to demonstrate personal assets such as a work ethic is seen as a means to assist future career prospects. This more instrumental motivation was very evident, as we shall see in the following section in terms of entrepreneurial citizenship.

\section{Learning for Entrepreneurial Citizenship}

Yes, I need to know about these stuff [citizenship knowledge/skills] to be a good person but there are also a lot of push towards to get into a good university, to get a good job as well as a good citizen, but more towards the job... Let's say 'do this, and you are more likely to get accepted by the University of Edinburgh.' I like winning, so any competition is good because you can win and work towards 'gold stars'. (Amy)

For many of these young people education in general was regarded as being crucial to gaining employment. But also being active and responsible members of the community was also valued. Gaining experiences in the community was understood as an asset for accessing more educational opportunities. Informal and 
in particular accredited learning opportunities were clearly valued by some of the respondents in these terms rather than or, perhaps equal to, any wider civic, social or political benefits their actions might confer on others. In this vein, participation in community-based learning and engagement was more associated with immediate, tangible outcomes, or "gold stars" which can be 'accredited to' to their personal curriculum vitae.

Formally organised programmes and activities by local or national charitable and voluntary agencies and NGOs were preferred to informal ones (e.g., helping next door neighbours) as they offer tangible certificates or proof of participation (e.g., a reference letter). From this standpoint, young people seemed to accept these domains of employability and entrepreneurial citizenship projects because they are informed, engaged 'responsible' citizens who strived to perform and achieve better than apathetic or disengaged ones. In short, community engagement was also a way of positioning themselves in the struggle for work.

\section{Learning for Formal Political Participation}

It [voting] is really important because all the women in the past protested to get us votes ...There is an issue of 'whether or not you want to vote', but you shouldn't neglect the right to vote. (Hannah)

In terms of formal political participation attitudes were generally positive which might be expected from young people more predisposed to the formal system. They were in favour of existing democratic institutions and fundamental democratic principles such as freedom, equality and social justice. Not surprisingly, the narratives on voting were particularly well articulated and well-reasoned, helped undoubtedly by their frequent involvement in relevant debates within peer groups and in the community. However, many were rather cautious when expressing their support for the right of 16-year-olds to have a vote in the referendum for Scottish independence; some suggested it was simply a cynical manoeuvre of the Scottish National Party to achieve their long-term agenda of independence by including young people who are 'supposedly' in favour of it. Nevertheless, the inclusion of 16-year-olds in the referendum vote seemed to be a significant 'landmark' in terms of expanding their right to participate in political processes.

Many believed that they were "lucky" to be a Scottish citizen:

I think that we are an exceptionally lucky country and we are. We do have a lot of freedom and rights but [in some cases like] LGBT marriage your not free to do that yet, but the reason it's so hyped up at the scale is the fact that it's not being ignored; there is things to be done about it and as it's taken into consideration. (Frankie)

General support for democratic institutions and values were held alongside a more critical view on age barriers created by the traditions and practices of these 
bodies. They were equally critical of the age barriers to participation in a range of organisations which are part of the social and political fabric of the country:

Obviously at my age, I am not allowed to vote in elections. I am not allowed to join a trade union and I can't join a political party yet. Participating in a democratic process is quite difficult because there are so many adults influencing it but we shouldn't just leave it to adults. (Frankie)

The experience of age discrimination resonated with what Bell (1995, p. 1) labels as 'adultism' - a term which 'refers to behaviours and attitudes based on the assumption that adults are better than young people, and entitled to act upon young people without their agreement". But this assumption that adults knew best was not accepted. There was clear dissatisfaction with politicians and political parties as well as trade unions. Their involvement with professional politicians, political leaders and other members of political parties and trade unions seem to aggravate their distrust and disaffection towards formal politics and its efficacy in representing or responding to actual demands of the people.

I don't really take them [trade unions] as seriously... Recently, there have been a lot of things about trade union. When it first started off, trade union was a great idea - it was got to do with health and safety; they had never lights and things like that. But now, they get discount cards and everything else is just commercial. It's all about we want this because we work; oh, we had a hard day so we are going to go on a strike during the (2012) Olympics; it's just so embarrassing. (Frankie)

Although Frankie's scepticism is perhaps an extreme case, it reflects a general alienation of young people from traditional political organisations along with other typical topics of democracy, government, politicians and political leaders. In contrast to this, learning in the community by engaging in practising citizenship through more direct politics was refreshing and welcomed.

\section{Learning for Activism}

My grandfather was really big in local politics in Leith [an area of Edinburgh]. My dad is also a very politically minded, he's got an opinion on everything. It's sort of goes through 'yes, it affects me'. It also annoys me and what am I going to do about it? (Charlie)

A predisposition towards activism was acquired, for some, from what they had learned in their family rather than from school or from community education. Yet there is no simple transmission of learning activism from family to the young person. The importance of being 'wary' of and 'attentive' to adults' influence on their understanding and development of citizenship was highlighted in Hannah's 
account below, which was particularly interesting in this regard as her mother is an elected member of the Scottish Parliament. Whilst she appreciates the opportunities her mother's involvement in politics had created for understanding social issues and related political debates, Hannah is reluctant to simply listen to or be "persuaded" by the views of her parents.

We [my parents and I] do talk about things but I try...to keep an open mind, not to be persuaded towards what they say. I don't want to think something because my parents are like that. I don't think it's right. (Hannah)

The range of issues that the young adults were involved in were somewhat eclectic and operated at different levels: beyond the state through global issues of sustainable development, ecological living, human rights and Scotland's international relations with other countries in and outside the EU; state level through national issues such as economic crisis, welfare reform, educational policies, referendum for Scottish independence, social inclusion and youth issues (e.g., right to vote, anti-social behaviour, juvenile crime); below the state through local community issues including discrimination against young people (e.g., no more than two young persons are allowed to enter a shop at one time), school's unsatisfactory curriculum provision in some subject areas (e.g., Modern Studies) and local community development projects.

There was a conscious effort amongst these young people to build a meaningful connection between the issue(s) and their everyday lives and get involved in action and activities to challenge and resolve them. Such commitment was associated with a strong sense of social responsibility towards others, not only within their immediate community but also beyond whereby factors such as distance and differences, which can diminish individuals' 'perceived' impact of the issue on their lives, do not undermine their engagement with the wider social issues.

In this respect, learning through community education and community-based citizenship education was recognized as providing a more 'neutral' understanding of the social issues. Similarly, their involvement in the Youth Congress was interesting in this regard, primarily because it was a space for learning that was perceived as non-partisan in the sense of exploring issues rather than already encountering fixed political positions. The value of non-politically partisan citizenship experiences was also found in relation to their engagement with environmental groups of the local community. To a large extent, there was a sense of urgency over environmental issues because of the impact of the rapid deterioration of the quality of life of the planet as a whole, hence requiring prompt actions to discontinue or at least decelerate further worsening. They valued action to raise awareness and volunteer in 'ecological or sustainable life' activities, where small efforts in everyday life such as recycling, growing garden vegetables, saving energy and cleaning up the neighbourhood areas are seen as steps on the way to bring about big changes. 
Promoting sustainable living; we [my family] already have vegetable plants in our garden. I've grown them a bit. To me, it's not so much a big thing but I am kind of okay with it. (Amy)

We do not wish to underestimate the impact of these small endeavours at a private and local community level; yet, these types of activity seem to put the focus on responsibility and resources back to each individual or community for voluntary actions at the micro level without making necessary demands for changes at the macro level.

\section{DISCUSSION}

We argue that the increasing emphasis on employability in policy is simply extending the colonisation of more formal educational concerns into the community through the focus of citizenship education. It is not the only 'show in town' but as resources get directed towards employability agendas the opportunities for a broader and critical range of citizenship education is diminishing. Focussing on an entrepreneurial version of citizenship has, of course, very little to do with democracy. The latter needs to at least have some focus on the public and collective interests of the community rather than the personal assets and skills of the individual. Moreover, young people wanting to position themselves in the struggle for work are increasingly aware of the instrumental value learning through community activity may offer in the job market. We are not suggesting that young people are being merely cynical and calculating in their community engagement. Indeed, they clearly show an interest in a range of different types of citizenship activity at different levels of engagement below the state, at the state level and beyond this. The kind of opportunities they value most seem to derive from engagement in non-politically partisan spaces for learning citizenship through activism in the community.

As the following table shows there is a good deal of convergence and overlap with the position taken by community educators and the young people.

The overlapping of views suggests that community education workers and young people have a shared understanding and mutually support learning for membership in terms of 'good' character traits such as neighbourliness, caring and connectedness. They also regarded involvement in activities such as volunteering and charity as being important. In this respect community primarily served as a source of young people's sense of belonging and social trust with community-based citizenship education being a fundamental part of youth socialisation. These characteristics do little, however, to improve young people's capacity to engage as political actors either in or against the state (see Biesta, 2011).

Andrea Cornwall (2003) underlines that institutionalised, or 'invited' spaces of participation, may offer only a restricted scope for meaningful democratic practices for citizens by which the existing power and status imbalance can be challenged. Nevertheless, both educators and young adults supported learning for formal 


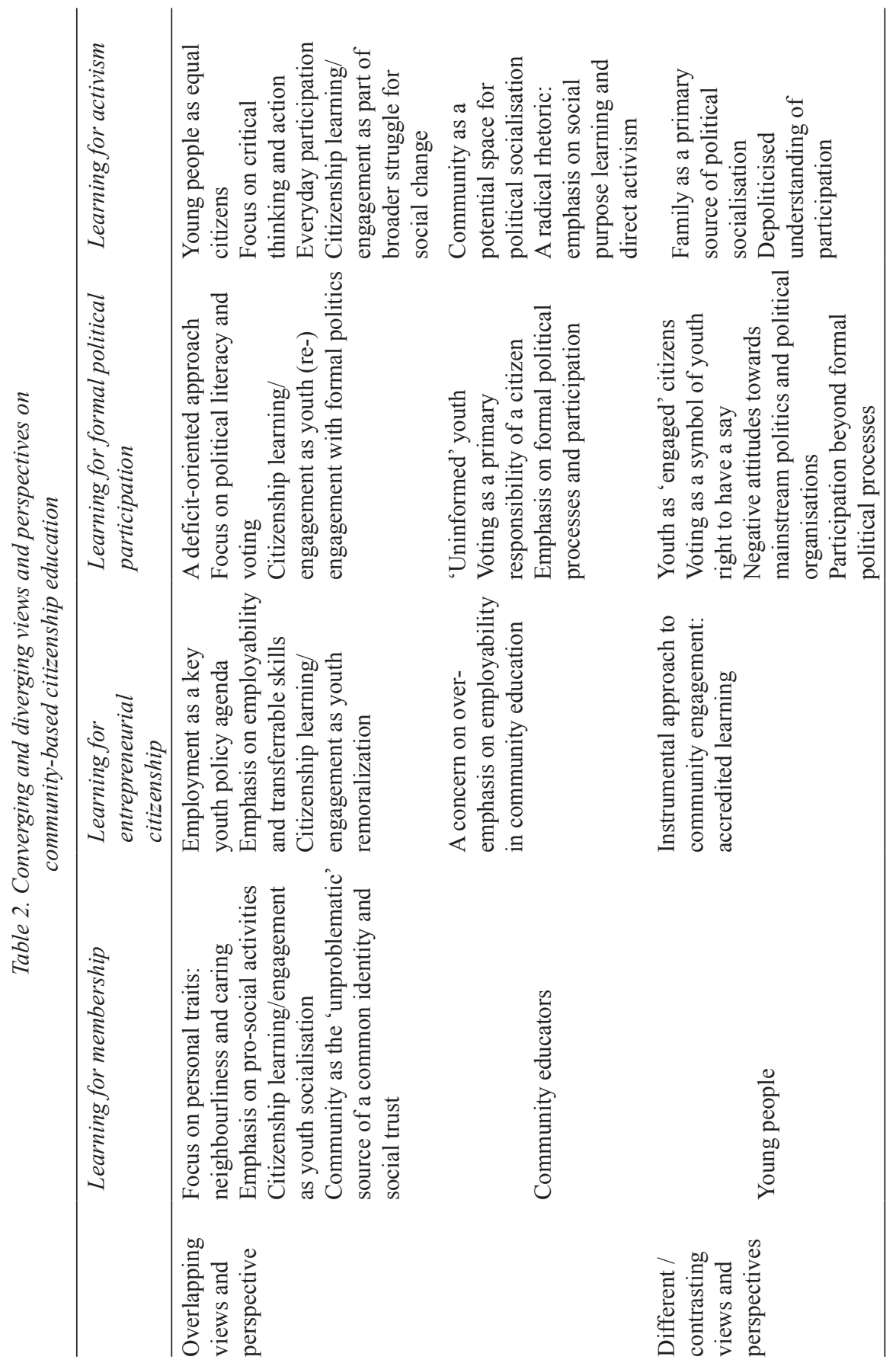


political participation, particular formal political literacy, which was essential for enabling young people's involvement in politics and formal decision-making processes. However there were distinctly different attitudes in this area. Community education workers believed that young people are lacking citizenship experiences, thus they are in need of adequate training and education opportunities. Communitybased citizenship education was an intervention to tackle this issue of youth deficit and voting was a key objective of developing young people into being engaged with formal political processes. By comparison, young people identified their interests and issues as being excluded or marginalised from the mainstream politics and political decision-making, rather than that they were apathetic or disinterested. The alienation and distrust young people expressed with the formal processes of democracy contrasted markedly with the value the community educators articulated in terms of engaging with it.

Young people shared strong negative attitudes towards formal politics including traditional mass-political organisations (e.g., political parties and trade unions), politicians and political leaders and voting, mainly for failing to include young people's voices and views as equal to adults'. For them, the current agenda to lower the minimum voting age to 16 in the Scottish referendum was integral in their fundamental right to have a say as in the UNCRC proclamation. This was closely linked to a call for participation beyond the 'invited' spaces of formal political participation.

Whilst there is little disagreement that the acquisition of knowledge and skills is essential for effective democratic engagement, many critics argue that an emphasis on political literacy is fundamentally problematic as it is more grounded on a 'deficit' approach which regards young people mainly as "lacking citizenship and as outside the community that acts" (Nicoll et al., 2013, p. 1). From this viewpoint, too much focus on political literacy may marginalise or exclude what is referred to as New Politics, or small politics whose key characteristics are emergence of 'private/personal' concerns as political issues and 'everyday' engagement as political participation, in which many ordinary citizens including young people are actively engaged.

Lastly, as for learning for activism, there were also mixed views. On the one hand, both community education workers and young people commonly acknowledged that learning for activism is a fundamental aim of community-based citizenship education and engagement. This often resonated with recent policy imperatives of youth empowerment as the United Nations Convention of the Rights of the Child (UNCRC) firstly proclaimed in 1991. Community served as the principal resource of citizenship education as a 'lived experience' where young people (re-)construct citizenship as relevant, being meaningful to their lives by reflecting their interests and concerns. In learning activism, however, young people have the opportunity to think and act as political agents (in the broad sense of this term). This type of engagement therefore provides the possibilities for engaging in democratic ways which can have the implications of changing imbalances of power. 


\section{CONCLUSION}

We would argue that issues of representation and power imbalances in existing youth participation programmes (i.e., adultism) were identified as major obstacles, causing (further) scepticism amongst the young interviewees about the raison d'être of youth participation and community-based citizenship education. The most distinctively contrasting views were over the nature of youth participation where the community education workers often associated their goal with a radical rhetoric of (Freirean) critical education, i.e., youth participation as a seed of wider social movement prepared to critically engage with formal institutions of democracy. Increasingly however this radical rhetoric diverges from the instrumental demands of young people's aspiration for improvement of their curriculum vitae (CV) and employability, a trend that is in tension with a struggle for social change or transformation.

The finding above is perhaps not surprising under the current neoliberal sociopolitical climate which often characterizes young people as idle, dependent, and irresponsible and therefore lacking the work ethic supposedly at the core of the current economic crisis and need for welfare reform. As a result, young people are pushed towards a focus on personal development as the aim of their community engagement and other community-based educational opportunities as a way of enhancing their career prospects. Considering the potential effects of this on the extent to which young people can be a resource for social changes towards a more democratic society, the emphasis on the struggle for work has to be seen as a political problem for democracy and an educational challenge for a critical pedagogy for learning citizenship.

The positive opportunity, as reflected in this account, is with the creation of non-politically partisan spaces for deliberation, which encourage young adults' participation, not merely as a step up to engagement into formal political processes and procedures, but as an opportunity to explore issues and concerns that allow them to think and act individually and collectively (i.e., as political agents). In learning citizenship in these terms young people might be able to provide a lead on how to change the practice of formal democratic procedures and processes. Democracy if it is to be meaningful has to encourage dissent and reform of its own institutions and processes. Liberal representative democracy as practiced in the UK today cannot be considered as the final stage of democratic development - as a kind of end stage of political history. Instead, we would argue that perhaps these institutions and practices have much to learn about democracy from the experiences of young people.

\section{NOTES}

The decision to give 16 and 17-year-olds the right to vote in Scotland was passed in the Scottish parliament at Holyrood on 16 June 2015.

2 The data was collected as part of Pyollim Hong's doctoral thesis on Becoming or Acting as a Citizen? Young People and Citizenship Education in Scotland's Formal and Informal Settings. 


\section{REFERENCES}

Anderson, B. (1991). Imagined communities: Reflections on the origin and spread of nationalism. London, England \& New York, NY: Verso.

Bell, J. (1995). Understanding adultism: A major obstacle to developing positive youth-adult relationships. Somerville, MA: YouthBuild USA.

Biesta, G. (2011). Learning democracy in school and society. Rotterdam, The Netherlands: Sense Publishers.

Cameron, D. (2013). David Cameron's speech, Conservative Party Conference 2013: Full text. Retrieved October 5, 2013, from http://www.newstatesman.com/staggers/2013/10/david-camerons-speechconservative-party-conference-2013-full-text

Coburn, A., \& Wallace, C. (2011). Youth work in communities and schools. Edinburgh, Scotland: Dunedin.

Cornwall, A. (2003). Introduction: New democratic spaces? The politics and dynamics of institutionalised participation. IDS Bulletin, 35(2), 1-10.

Craig, G. (1989). Community work and the state. Community Development Journal, 24(1), 3-18.

Crowther, J., \& Martin, I. (2010). Adult education and civil society. In P. Paterson, E. Baker, \& B. McGaw (Eds.), International encyclopaedia of education (Vol. 1). Oxford, England: Elsevier.

Deuchar, R. (2007). Citizenship, enterprise and learning: Harmonising competing educational agendas. Sterling, TX: Trentham Books.

Fyfe, I. (2010). Young people and community engagement. In L. Tett (Ed.), Community education, learning and development (3rd ed.). Edinburgh, Scotland: Dunedin Academic Press.

Henn, M., \& Foard, N. (2012). Social change and political engagement among young people: Generation and the 2009/2012 British election survey. Parliamentary Affairs, 65(1), 13-28.

Kerr, D., Ireland, E., Lopes, J., Craig, R., \& Cleaver, E. (2004). Citizenship education longitudinal study: Second annual report: First longitudinal survey: Making citizenship education real (Research report no. 531). London, England: DfES.

Learning and Teaching Scotland. (2011). Developing global citizens in curriculum for excellence. Glasgow, Scotland: LTS.

Lister, R. (2007). Social justice: Meanings and politics. Benefits, 15(2), 113-125.

Martin, I. (1987). Community education: Towards a theoretical analysis. In G. Allen, J. Bastiani, I. Martin, \& K. Richard (Eds.), Community education: An agenda for educational reform. Milton Keynes, England: Open University Press.

Martin, I. (2008). Reclaiming social purpose-framing the discussion. In Reclaiming Social Purpose Group (Ed.), Reclaiming social purpose in community education: The Edinburgh papers. Edinburgh, Scotland: The University of Edinburgh.

Mayo, M., Gaventa, J., \& Rooke, A. (2009). Learning global citizenship? Exploring connections between the local and the global. Education, Citizenship and Social Justice, 4(2), 151-175.

Nicoll, K., Fejes, A., Olson, M., Dahlstedt, M., \& Biesta, G. (2013). Opening discourses of citizenship education: A theorization with Foucault. Journal of Education Policy, 28(6), 828-845.

O’Hagan, B. (1991). The Charnwood papers: Fallacies in community education. Derbyshire, England: Education Now Books.

Painter, J. (2008). European citizenship and the regions. European Urban and Regional Studies, 15(1), $5-19$.

Putnam, R. (2000). Bowling alone: The collapse and revival of American community. New York, NY: Simon and Schuster.

Ranciere, J. (2003). The philosopher and his poor. Durham, England: Duke University Press.

Ross, H., Munn, P., \& Brown, J. (2007). What counts as student voice in active citizenship case studies? Education, Citizenship and Social Justice, 2(3), 237-256.

Schugurensky, D. (2000, June). Citizenship learning and democratic engagement: Political capital revisited. Conference Proceedings at the 41st Annual Adult Education Research Conference, Vancouver, BC.

Shaw, M. (2008). Policy, politics and practice: Community development. In Reclaiming social purpose in community education: The Edinburgh papers. Edinburgh, Scotland: The University of Edinburgh. 
Tett, L. (2010). Community education, learning and development (3rd ed.). Edinburgh, Scotland: Dunedin Academic Press.

Tett, L., Bamber J., Edwards, V., Martin, I., \& Shaw, M. (2007). Developing competence: Early and mid-career in community learning and development. Glasgow, Scotland: Learning Connections.

The Edinburgh Papers. (2008). Reclaiming social purpose in community education. Edinburgh, Scotland: Reclaiming Social Purpose Group.

The Scottish Government. (2013). Unemployment in Scotland falls by 4,000. Retrieved October 4, 2013, from http://www.scotland.gov.uk/News/Releases/2013/03/Unemployment-figures-20032013

UNICEF. (2011). The United Nations convention on the rights of the child. London, England: UNICEF, UK.

Westheimer, J., \& Kahne, J. (2004). What kind of citizen? The politics of educating for democracy. American Educational Research Journal, 41(2), 237-269.

West Lothian Council. (2011a). West Lothian: A profile. Livingston, Scotland: West Lothian Council.

West Lothian Council. (2011b). Community planning and regeneration: Annual report 2010/11. Livingston, Scotland: West Lothian Council.

West Lothian Council. (2013). West Lothian economic profile 2013. Livingston, Scotland: West Lothian Council.

West Lothian Economic Partnership. (2013). West Lothian economic. Retrieved January 3, 2014, from http://www.westlothian.com/Home/wl_economy/facts_figures/

\section{Pyollim Hong}

University of Edinburgh, Scotland

Jim Crowther

University of Edinburgh, Scotland 



\title{
CHRIS PARSON
}

\section{ADULT LITERACY AND EMPOWERMENT}

\author{
Learning for Freedom
}

\section{INTRODUCTION}

This chapter sets out to examine the experience of a mixed group comprising adult learners, tutors and voluntary sector management from five European countries, speaking (and not necessarily sharing) four different languages, as they embarked on a process of exchanging and critically analysing learning/teaching methodologies in the field of adult literacy. ${ }^{1}$ We begin by briefly sketching the rather different approaches to literacy (or rather illiteracy) that tend to prevail in French-speaking countries - five of the seven project partners come from francophone regions of Europe - and particularly in Switzerland. Approaches which tend to influence both tutors and learners' expectations and postures when participating in collective activity. The chapter goes on to consider how - and to what extent - participatory methodologies whose stated aim is to give place and power to learners' voices can actually help realise meaningful transformations in the way we 'do' adult learning.

\section{BACKGROUND AND CONTEXT}

Let me start by saying something about the adult training and education background from which we came to participate in this project, and in particular about adult literacy and power sharing issues. We work in a rather 'remote' French-speaking region of central Europe, in the Lake Geneva area of Western Switzerland. Of course, we use the term 'remote' in a somewhat tongue in cheek fashion: Switzerland is geographically at the heart of Europe (and in many ways at the heart of many global debates and political processes), but it has in the course of recent history, come to occupy a somewhat peripheral position with regard to the political and economic organisation of Europe, as represented by the 28 members of the European Union. The Swiss have, by and large, preferred to 'go it alone' as far as possible in order to preserve their neutrality and what they regard with pride as a unique form of participative democracy. Participation in democratic processes is at the heart of what we want to explore in this chapter, so it might be useful - and not entirely irrelevant to say something about the political structure and organisation of Switzerland.

Although culturally and intellectually very close to France, the French speaking region of Switzerland (Romandie) is very much part and parcel of the Swiss 
Confederation $(\mathrm{CH})$. A small country with four national languages, sub-divided into 26 cantons and half-cantons, which are effectively tiny republics or states, each having its own government and parliament, and each responsible for legislation in areas such as education, health, social policy and income tax. This means for instance, that there are 26 ministers of education, 26 school systems, and different qualifications for teachers in every canton. There is no federal minister for education. This is a far cry from the very centralised political system in France.

Switzerland is thus a very decentralised country and this has advantages and disadvantages. Political change is slow, as citizens - also known as the sovereign - are consulted on all major changes in federal, cantonal and municipal legislation and can initiate referendums on almost any issue - the banning of the construction of minarets being the latest example! The Swiss are fiercely protective of their system of direct democracy and this is one of the major reasons why Swiss people are reluctant to join the European Union.

However, in the field of adult education, scientific research has been very much linked to activity in the French-speaking world (France, Belgium, Quebec) and is particularly influenced by francophone trends in sociology, psychology and the tradition of éducation permanente. In terms of policy and provision, adult education and training has been mainly financed on the basis of legislation in the field of vocational and in-service training, though since significant rises in unemployment since the early nineties, interest and activity in the field of basic skills training has seen a sharp upturn. There is no national agency responsible for informing policy on such matters, and no centralised source of funding. Non-vocational adult education is very much the affair of the voluntary sector in Western, French-speaking Switzerland, with a strong tradition of volunteer involvement in terms of teachers and tutors. This situation raises a number of issues linked with funding policy, training of trainers, evaluation etc., too numerous to be dealt with here.

One exception to this general picture is the situation in the city of Lausanne, the region's second largest city after Geneva. The city of Lausanne decided in 1995 to create and fund a community education programme for adults excluded from all other learning provision, and turned to the voluntary sector for expertise and experience. In this way, the municipal authorities were able to develop and fund a wide range of activities in the area of literacy and numeracy, ICT, French for speakers of other languages and other areas of basic learning for thousands of men and woman, many of them first or second-generation migrants. Social policy had been influenced by a wide-ranging research project into urban poverty (Cunha et al., 1995). One of the findings of this research project was the correlation between the degree of development of individuals' cultural resources, including education, and their position on the socioeconomic ladder in local society. Significant investment in free adult learning provision was considered to be a way out that would encourage autonomy, lead to greater individual responsibility and thus favour emancipation from social welfare benefits. 
A word about literacy and numeracy learning in France and Switzerland: The concept of literacy is something very recent. In France and Switzerland, since the early 1980s, attention has been focussed on the 'struggle against illiteracy' (la lutte contre l'illettrisme), a notion promoted by the French fourth world charity ATD Quart Monde in the late seventies. Illiteracy is therefore something to be eradicated, rather like the plague - an often used metaphor - and the approach has long been very much school-based, with goals and bench marks set in terms of competencies and skills normally supposed to have been acquired before minimal school leaving age. This is based on a deficit model of adult education and training, and is seen as remedial, second chance education, and also linked to promoting social change and improving citizenship skills etc. In Switzerland, adult education in the field of literacy has become very much an issue for new social movements, whose goal is not simply to provide learning opportunities for adults, but to combat what is perceived as a social blight. From 1988 onwards, this work has been largely carried out by the Association Lire et Ecrire in French-speaking areas of Switzerland. This contrasts with the situation in France, where a national agency for the fight against illiteracy (ANLCI) coordinates activity over the whole of metropolitan and overseas French territory.

As a voluntary sector organisation in Lausanne (Lire et Ecrire) involved in providing reading and writing courses for adults, the posture adopted was traditionally one of fighting against something perceived as socially bad: illiteracy. This rather nebulous concept is almost impossible to define and has been seen by certain critics to have simply replaced the notion of failure at school (échec scolaire). At the same time it provides a convenient banner under which to mobilise militant volunteers keen to engage in righting a perceived social wrong and, more importantly, a handy stick with which to beat public authorities into providing funding. The French sociologist, Bernard Lahire, has been quite virulent in his criticism of this (Lahire, 1999), accusing those involved in fourth world social movements of fabricating a social phenomenon which is hardly representative of the difficulties with reading and writing experienced by adults in their everyday lives. For Lahire, we are witnessing:

... la fabrique collective de l' "illettrisme", cette extraordinaire machinerie imaginée par personne mais résultant d'une multitude of discours, d'actes et d'institutions - qui a créé, par la magie d'un immense et intense travail symbolique, un "problème social", considéré désormais comme une priorité nationale au niveau des plus hautes instances of l'Etat. (Lahire, 1999, p. 2)

Lahire takes issue with the "industry of illiteracy" in France and the excesses of some researchers, notably the very media conscious Alain Bentolila, pointing out the absurdity of transforming the teaching of reading and writing at primary school into a series of preventive measures aimed at stamping out illiteracy in later life. In this way, Lahire points the way to research findings in new literacy studies (Barton, Barton \& Hamilton, Street etc.) and their focus on social practices of literacy. 
Awareness of some of these issues led to a gradual change in the way provision was conceived and organised. Emphasis shifted to trying to help learners' achieve their goals, as expressed by them, once they had been given the chance to actually say something about what they wanted to do, rather than being placed or 'inserted' into ready-made programmes. Words such as emancipation, autonomy, freedom, power, decision making, critical awareness started to appear in the vocabulary of tutors and managers. One of the paths towards "learning our way out" (Finger \& Asun, 2001) of this rather negative mind-set was seen to be active participation in European networks and close links were established with similar organisations in Belgium and France.

\section{GRUNDTVIG 2 PARTNERSHIP PROJECT - ADULT LITERACY AND EMPOWERMENT}

The opportunity to act on this desire to participate actively in exploring alternative approached to literacies learning came with the Grundtvig project, Adult literacy and empowerment. From 2005 to 2008 , seven voluntary bodies actively involved in adult basic education provision from $5^{2}$ European countries worked together on a Grundtvig 2 partnership project whose principle aim was to explore and promote the emancipatory dimensions of adult literacy work in Europe. At the outset, the project partners identified their goal as follows:

Exchange, mutualisation, critical assessment between partners actively involved in adult literacy provision in Europe, of tools, methods, practices and methodological processes which contribute to individual and collective autonomy and emancipation or empowerment in the field of adult literacy, and more largely, in terms of active citizenship.

According to the European Commission, the Grundtvig programme aims to address the teaching and learning needs of those involved in adult education, thus aiming to provide new learning opportunities for all and especially for adults at risk of social exclusion. It is particularly aimed at bringing together learners, teachers and organisations in adult education enabling them to exchange experiences, learn from each other and develop new approaches in adult education.

Particularly significant were the emphasis on mobility, including visits and adult education exchanges and the preparations needed to plan the exchanges. This was fundamental to the project we designed and it was planned to spend two week-long residential sessions per year in each of the partner countries. Grundtvig Learning Partnerships also focus on themes of mutual interest to participating organisations, which, as we will show below, was of particular significance to project partners.

During the European contact seminar in Brussels October 2004, representatives from several organisations came together to discuss the possibility of working together to explore methodologies fostering empowerment in adult literacy learning. Following a broadly Freirian inspired outlook on adult literacy learning, partners 
were particularly interested in dialogic communication and the potential for mutual recognition through an exploration of best practice in terms of methodologies promoting democratic participation and empowerment. Exchanges were to centre on existing empowerment practices, which had been tried and adopted by partners, in order to increase complementarities and enrich pedagogical approaches. It was thought that these exchanges would allow the establishment of an inventory of empowerment pedagogical practices in the field of adult literacy training.

Other underlying issues included:

- The political dimensions of learning.

- The relationship between the written word and power in a literacy driven, knowledge-based society, particularly as it affects those perceived as being "outside" the literate world.

- Questions of authorisation, legitimacy.

- Learners' voices... learners' choices.

The project aimed at strengthening the emancipatory dimensions of pedagogical practices involving adult learners and more generally for their roles as citizens in the countries in which they now lived. Exchanges were to centre on existing empowerment practices, which had been tried and adopted by partners, in order to increase complementarities and enrich pedagogical approaches. It was thought that these exchanges would allow the establishment of an inventory of empowerment pedagogical practices in the field of adult literacy training.

In concrete terms, this involved the learning of an oral language, in general, that of the host country, which in practice meant French, English and Basque. It was decided that three methodological approaches would be experimented (for learning the languages), shared and critically analysed:

- Reading and writing practices as developed in the ECLER (Ecrire, Communiquer, Lire, Exprimer, Réflechir) workshops. ${ }^{3}$

- The participative process of individual and collective emancipation, as developed in the REFLECT-ACTION ${ }^{4}$ approach.

- The Wheel, part of the Scottish framework for adult literacy and numeracy learning.

\section{REFLECT-ACTION}

The REFLECT participative methodology, largely inspired by the work of Paulo Freire, was the theme of the first week's work and was soon adopted as a methodological working framework for all subsequent meetings. This decision permitted a significant shift in emphasis from the establishment of inventories of best practice to an ongoing analysis of what was actually happening in terms of power distribution and active participation within the group as it progressed. Those participating in the project fell into three broad categories: learners, trainers and 
tutors, managers. Within these three categories, language and communication skills were unevenly distributed, whilst attributes such as self-confidence, communication and analysis skills, tended to be concentrated amongst the tutors and managers. Some tutors and trainers found themselves participating alongside their hierarchical superiors. In other words, the distribution and use of power, implicitly or explicitly manifested, was an issue. At the same time, not all learners had the same expectations in terms of power sharing and outcomes, and it soon became evident that the process itself was becoming the focal point of the partnership.

The adoption of Reflect Action as a working methodology was a key decision. The first week on Belgium allowed all those participating to acquire a working knowledge of the tools and processes involved in Reflect and in particular allowed learners to claim some space for themselves and to feel more at ease at expressing themselves in a group.

The seeds of a Freirian approach were sown with the inclusion in the project goals of the term "mutualisation", and the proposition to use Reflect Action as the first methodological approach to be shared. Reflect-Action proposes a methodology, or rather a process whose aim is to foster participation in democratic life, taking up and expressing one's position, improved communication skills, analysing and sharing power. Its principles are consistent with those of lifelong learning, or at least as expressed in discourse on LLL. The process itself involves experiencing and analysing situations - both individual and collective - using animation techniques aimed at facilitating analytical reflection. It can be used with groups of adult learners or in any group setting where transformation is one of the goals. It allows the group to establish its own analytical and working framework by means of the participation and engagement of all the members of the group.

Reflect was conceived originally to provide an on-going democratic space for a group of people to meet and discuss issues relevant to them. Participants would choose the topics themselves, according to their own priorities and supported by a local facilitator. They also decided where and when to meet.

Clearly, in the context of a European adult learning partnership, involving complex application forms, administrative procedures, negotiation for funding, planning and organisation etc., the spontaneous, user motivated aspects of Reflect could not be honoured in full. What seemed important and exciting at the planning stage of the project however, was the fact that underpinning the Reflect approach is a huge (and ever expanding) range of participatory methods, which could be used to encourage engagement and participation of those less at ease with group activities, speaking in public, talking about themselves, being critical, taking up and defending personal points of view.

Prominent among these are graphics such as calendars, maps, matrices, rivers and trees, which enable participants to communicate their knowledge, experience and feelings without being restricted by literacy and language barriers. Drama, storytelling and songs are also used to identify and analyse social, economic, cultural and political issues. In this process the development of literacy and other 
communication skills are closely linked to the engagement of people in wider processes of development and social change.

Reflect is based on a series of core principles, derived both from the theoretical foundations of Freire and Participatory Rural Appraisal and through practical experience. The three fundamental pillars of the approach are:

- Behaviour and attitude of facilitators, which must avoid any form of domination;

- Methods, which are open, more often visual and comparative and oriented towards the group;

- Sharing of information, experiences, but also of accommodation and food by all participants.

A wide range of participatory tools is used within a Reflect process to help create an open, democratic environment in which everyone is able to contribute. Tools and activities are chosen in terms of their propensity to encourage all participants to understand, analyse and criticise data and to develop any subsequent actions and also for their accessibility to all members of the group as a means of fully comprehending what is happening and of fully implicating themselves in the process. Visualisation approaches are of particular importance (calendars, diagrams, maps) though many other participatory methods and processes were also used during the project, including theatre, role-play, song, dance, video and photography.

Reflect is thus a process that aims to strengthen people's capacity to communicate by whatever means are most relevant to them. Although part of the process may be about learning new communication skills, the focus is on using these in a meaningful way. It is through focusing on the practical use that real learning takes place. Reflect can therefore claim to be a political process inasmuch as it promotes the creation of democratic spaces and demands a continual, ongoing analysis of how power is shared within the group.

Reflect begins with respecting and valuing people's existing knowledge and experiences. The key is to share power within the group, enable participants to take control. This involves a continual cycle of reflection and action, not simply for learning for the sake of it, but rather as a means of producing change. However, with Dubet (2009) we could ask questions about the 'logic of action' in relation to power relations and power sharing, particularly in relation to institutions and organisations:

A la régulation verticale, par l'autorité, se juxtapose une régulation horizontale construite par le jeu des acteurs qui s'efforcent d'accroître leur capacité de jouer et de développer leurs propres stratégies.... Ici, la logique fondamentale n'est plus inscrite dans les définitions de rôle, mais dans la capacité d'accumuler du pouvoir, c'est-à-dire de se protéger du pouvoir des autres et d'être capable de peser sur leurs choix. (2009, pp. 188-189)

Of course, autonomy or increased empowerment, may only be illusions, or only be effective, or tolerated, in certain settings. We may be inclined to agree with 
Bandura that: "The capacity to exercise control over one's own thought process, motivation and actions is a distinctively human characteristic. Because judgements and actions are partly self-determined, people can effect change in themselves and their situations through their own efforts" (Bandura, 1989, p. 1175). But feelings of self-efficacy were generally perceived to be low amongst learners, and whilst the empowering process was certainly a boost to individual and collective agency, some doubts lingered as to the enduring nature of personal transformation, particularly in the face of the power of organisations and systems. Actions may be 'partly self-determined', but that part may be fairly minor compared to the part that is impersonally or socially determined: "Ordinary people, men and women, often feel that their lives have become a series of traps. This impression of being ensnared has its source in the structures of society" (Wright Mills, 1959).

On several occasions, we did look at how power was distributed in the group. Status, language, education, experience were all seen as affecting the ability of participants to assume different roles: participating, positioning, making people laugh, maintaining one's place in the presence of others, organising etc. In order to do this in a fully participative manner, the group decided to use a matrix. A matrix is a table or graph, which shows a set of elements across the top and another set of criteria or classifications down the side. Matrices can be constructed on almost any topic, and were used throughout the project, particularly as a way of evaluating activities. Thus a large coloured matrix would be displayed throughout each week's residential meeting and be filled in by everyone involved after each activity. They can also be used to represent, in a systematic way, the capital of information or knowledge held in the group around a particular issue or topic. Alternatively, they can be given a stronger analytical role, where different elements or items are evaluated as they are entered onto the matrix. A matrix can help to structure discussions on complex issues: usefully consolidating information and comparing items in a systematic, visual way.

Another tool that was used on several occasions during the project was the River. The river is a powerful symbol. It permits us to review the flow of time (present, past and future) and the course of our lives. The river flows, it can be calm or troubled, slow or rapid, presenting dangers and possibilities, obstructions and currents, which may be with us or against us. Its changing width, current and direction as well as features such as whirlpools, islands, rapids, waterfalls and forks, can represent changes and events in our own histories. In richly illustrated rivers the surrounding landscape can represent the environment that forms us. If being used to map an individual's personal journey, it will be constructed individually. However, it might be used to represent the history of a community or organisation, in which case the process would be communal.

A third method employed was the "empowerment moment", in which individuals are asked to reflect on a particular occasion when they had felt empowered and then share this moment with the larger group. Visual and movement techniques were used to illustrate these moments and make them more accessible to others. 
Evoking and expressing our empowerment moment within the group allowed us to feel less alone and to overcome our fears... to go further, to go beyond ourselves, to become more aware of the distance we have already travelled during our lives. Listening to others also helps us learn from them and build meaning together (Amaya, Basque Country).

It became clear as the project proceeded, that Reflect needed to be used systematically. The same principles and processes had to apply to all the participants, whatever their status and power within or outside the group. It was seen as particularly important that the facilitator should engage in the process alongside the participants, subjecting their behaviour, experiences and opinions to the same analysis, rather than standing outside as a teacher and judge.

\section{ECLER}

The general feeling at the end of the first week was that important ground had been made up in terms of increasing democratic participation in the learning process, in spite of many inequalities in terms of educational background, status and language skills. In subsequent meetings, a second empowering methodology, ECLER, was introduced, and served particularly to enable texts to be written individually about many of the themes that were under discussion and then shared and socialised within the larger group.

ECLER is organised on workshop principles, and involves movement through different activities in a designated space and individual and collective work. It aims to promote a large degree of autonomy amongst learners, but also expects it of them at an early stage. Underlying the ECLER approach are several pedagogical principles, which reinforce its claims to be an empowering, emancipatory methodology. These principles have been broadly expressed in the past by the likes of Knowles, Mezirow, Brookfield, Jarvis and many others, and are also close to the position adopted by French educationalist Anne Vinérier in her Freirian-inspired, hologrammatical approach, Des Chemins de Savoir.

Firstly, the learner is not considered as someone who is defined in terms of what he or she does not know, but rather as a subject who has constructed significant knowledge, albeit outside the formal boundaries of school based education as expressed in the 3 R's. The learner has displayed and applied skills and know-how in order to cope with everyday situations, which normally require basic schoollearned skills, and these skills are constitutive of what could be described as a complex cognitive and affective strategy. These skills and strategies, if recognised, can be mobilised in new learning situations, and are an advantage rather than a disadvantage.

Secondly, the tutor, trainer, educator, teacher or whatever we choose to call the formateur, is not primarily a transmitter of knowledge, but rather a person who accompanies someone else who has already travelled along a path without using reading or writing skills (or being able to speak or understand a language in some 
cases) but who now wishes to acquire and develop these skills. Thus the adult educator is a partner in a process of change, a process which involves crossing frontiers into hitherto unknown territory.

Thirdly, the educator is invited to take a risk with the learner, a risk that the learner may find difficult to take alone. The learning process involves change, transformation, and there is a risk involved in changing form. Some learners have described improving literacy skill as "the world becoming bigger", and speak of the change in their relationship to others and with themselves. This risk taking is also an expression of solidarity. This notion of transformation is clearly present, particularly in French where the word for adult education and training is "formation". The question of who decides the form and the dangers of adult education being instrumentalised in order to promote certain preconceived forms was to be tackled directly at a later stage.

Philippe Meirieu (2002), speaking of the changes involved in crossing the frontier into the world of reading and writing, says that learning to read is "an act of resistance" and mentions three major symbolic ways in which improving access to language "makes sense" for adults at risk from social and economic exclusion. He believes that it is essential to show adults that:

- reading is a means of resisting all forms of exploitation;

- reading is a means of acceding to a certain number of "secrets";

- reading is a means of moving out of solitude.

ECLER is a means for learners to express their voices, making demands, resisting and defending a vision of adult learning opportunities. Writing workshops allowing individual texts to be read by others and to contribute to a collective text. This was particularly valuable in the third phase of the project in which texts to be included in the manifesto were written and shared, critically analysed and adopted by the group.

\section{RUMBLINGS AND GRUMBLINGS - A MANIFESTO IS BORN}

The group very quickly took possession of the project. This in turn led to a strengthening of resolve in terms of participation and a strengthening of the project itself. The project was carried more and more by the collective as the meetings took place, as the individual and collective needs of participants, particularly those of learners, were taken into account. One event in particular during the first French meeting was pivotal in the transformation of the project, leading to a moment of crisis and then a significant change in the way things were done.

Language was an ongoing issue. A majority of participants spoke only French, others only English, whilst a few others, mostly tutors or managers, were either bilingual or could get by in French, English and Spanish. The participants from the Basque country were prepared to speak in Spanish so that their words could be translated into English and French, although this represented a political compromise 
for them based on pragmatic considerations. There seemed to be a high degree of correlation between power within the group and language skills.

Scottish learners in France felt that their specific language needs were not being respected and on the third morning decided to stay in their rooms and not participate any further in proceedings. This "strike" led to a crisis meeting among several members of the project coordinating team and it was decided to cancel the programme and work on the awareness raising and analysis of this problem. Following a long and emotional group discussion, it was decided to devote more time and resources to language facilitation and establish clear rules about language use, even if this meant not finishing the planned programme.

There was a growing feeling - a feeling that had been expressed by the Scottish learners in France - that exploring different approaches wasn't enough. Activities were not easily accessible to everybody, and this meant that power was not being distributed equitably within the group. The methodology we were using - Reflect together with the very real power sharing already in place within the Scottish group, facilitated awareness that the underlying question was one about how learners' needs are heard and taken seriously. This is more than just "Learners' Voice". This is hearing, taking seriously, acting upon learners' expression of their needs and demands. Was it legitimate, some asked, for learners (who should be grateful for what is already being done for them) to make demands? Issues of authorisation, and self-authorisation were raised. The liberty to make claims and demands required authorisation from the group, and a recognition that the uneven distribution of power and resources within the group, mirroring the situation in the larger society, justified such demands being made. Again, some risks needed to be taken, particularly by those who had the most to lose. The process allowed learners' demands to be expressed and, to some extent to be met, at least within the relatively protected setting of the group. The challenge, and the underlying anxiety felt by many participants, was what could be made of these demands and statements once the project had come to an end. The very emotional scenes filmed as the final week drew to a close bear witness to these mixed feelings of gratitude for what had been achieved together and fear of returning to the real world, a sort of end of holiday feeling in the pit of the stomach!

The process led to a growing desire to resist what were perceived as normalising policies, to make claims for approaches centred on learners needs, beyond exchanges of "best practices." This was being experienced by all participants, including managers, who had also shared concerns about shifts in funding policies in their respective countries and the dangers of instrumentalisation and normalisation. A third phase was then added, dedicated to the drawing up of a manifesto for learning, for and mostly by the learners.

It was decided to devote the final phase of the project to a new objective: the drawing up of a manifesto for the freedom to learn. The manifesto would be in two parts: a written document containing claims and demands, drawn up by all members of the group, and a film illustrating the participatory empowerment process involved in the writing of the manifesto. 
The main focus of the manifesto was to try and answer the following question: What kind of adult learning do we want? The answer was to be organised according to four principle themes:

1. The conditions for learning.

2. The notion of the learner at the centre.

3. The right for learners to choose their own path.

4. Action plans for the future.

The one clear demand that was made unanimously was captured in the slogan: Freedom to learn-learning for freedom! This then became the title of the manifesto. The manifesto is too long to reproduce here, and it would be wrong to try and paraphrase what was actually written by learners themselves at the end of this three year-long process. The following extracts from the manifesto surely speak for themselves:

In this manifesto, we do not seek to set down concepts and theories for adult learning. Rather, we ask that our voices be heard when we speak of our experiences, our hopes and plans for the future, our frustrations and pain in the present. We have shared ways of learning over these past few years and seen what works well for us and what might work well for others. Our way has been worn by many feet and is based on sharing what we have learned and how we have learned with all those who wish to advance on the learning path. (extract from the introduction to the manifesto)

\section{WE DREAM... AND WE WANT TO FIGHT FOR:}

An education where everyone becomes his own creator, where we may choose our own tools, where we are allowed to learn what makes sense to us and in a way that is in line with our needs.

A welcoming education that enables a relation of confidence and where, as adults, we are partners responsible for planning, negotiating and organizing learning

No to normalisation and to a single line of thinking.

No to standardisation and locking up.

We have different times and rhythms; we want to work in mutual aid, sharing and solidarity. We all have different acquired knowledge and pasts. This is our richness!

Each woman and man has resources that can help improve society

Here is what our learners' voices are telling you:

"Equality and justice for us."

"To give a chance for everybody."

"Each woman and man has resources that help improve society."

"I want to work." 


\author{
"I want to learn." \\ "I want choices." \\ "I want equalities." \\ "I want someone to give me a chance." \\ "I want to be listened to."
}

\title{
NOTES
}

1 I use the generic term 'literacy' in the text, though I am well aware that there are many 'literacies' and 'numeracies'. This is not meant to imply any standard or dominant model of adult literacy.

2 The seven partner organisations were: Collectif Alpha - Brussels, Lire et Ecrire Hainaut Occidental \& FAFEP - Fédération des Associations pour la Formation et l'Education en prison (Belgium), Association ATELEC "Lettres pour l'être" Bourg.en-Bresse (France), North Lanarkshire Council (Scotland), ELHUYAR-ZUBIZE, S.L.U. (Spanish Basque Country), Association Lire et Ecrire section Lausanne (Switzerland).

3 Writing, Communicating, Reading, Expressing, Reflecting. The ECLER approach was conceived and developed by French adult educator, Noël Ferrand, and has been adopted widely in France, Belgium and Switzerland.

4 Regenerated Freirian Literacy through Empowerment Community Techniques University of Geneva.

\section{REFERENCES}

Bandura, A. (1989). Human agency in social cognitive theory. American Psychologist, 44(9), 1175-1184. Retrieved from http://psycnet.apa.org/doi/10.1037/0003-066X.44.9.1175

Barton, D. (2007). Literacy: An introduction to the ecology of the written language. Oxford, England: Blackwell Publishing.

Barton, D., \& Hamilton, M. (1998). Local literacies: Reading and writing in one community. London, England: Routledge.

Bentolila, A. (1996). De l'illettrisme en général à l'école en particulier. Paris, France: Plon.

Cunha, A., Vez, I., Marcel, J., Leresche, J., \& Pedrazzini, Y. (1995). Pauvreté urbaine and exclusion sociale (Research report no. 125). Lausanne, Switzerland: IREC.

Dubet, F. (2009). Le travail des sociétés. Paris, France: Seuil.

Finger, M., \& Asun, J. M. (2001). Adult education at the crossroads: Learning our way out. London, England: Zed Books.

Freire, P. (1996). The pedagogy of the oppressed. London, England: Penguin.

Jarvis, P. (2007). Globalisation, lifelong learning and the learning society: Sociological perspectives. London, England: Routledge.

Lahire, B. (1999). L'invention de l'illettrisme: rhétorique publique, éthique et stigmates. Paris, France: La Découverte.

Learning for Freedom - Freedom to Learn. (2008). A manifesto for adult learning in Europe. ATELEC, Collectif Alpha, Lire et Ecrire Hainault occidental, Lire et Ecrire Suisse romande, Elhuyar, North Lanarkshire Council.

Meirieu, P. (2002). Illettrisme and exclusion. Paper given at the Agence Nationale de Lutte Contre L'illettrisme, Lyon, France.

Morrow, R. A., \& Torres, C. A. (2002). Reading Freire and Habermas: Critical pedagogy and transformative social change. New York, NY: Teachers College Columbia University.

Street, B. V. (1984). Literacy in theory and practice. Cambridge, England: Cambridge University Press.

Vinérier, A. (1994). Combattre l'illettrisme. Paris, France: L'Harmattan.

Vinérier, A. (2005). Des chemins de savoir. CRDP: Académie d'Orléans-Tours.

Wright Mills, C. (1959). The sociological imagination. New York, NY: Oxford University Press. 
C. PARSON

Chris Parson

Department of Educational Sciences/Adult Education

University of Geneva, Switzerland 


\section{SOCIAL CAPITAL, ADULT LEARNING AND EQUALITY}

It is widely acknowledged that social capital is a value in its own right. Membership in various organizations and networks is a process of building joint interests and shared norms, which in turn produces trust and better understanding of differences in culture, background and life-style. During this process democracy can emerge and individuals can have the opportunity to capture rights and benefits. From a slightly different viewpoint, it is emphasised also that the social capital created within a social structure, such as reciprocity or mutual aid, increases the opportunities for collective action (Oyen, 2002).

Where there is social action, there is learning. This observation underpins a paradigmatic shift from defining adult learning primarily as an acquisition process towards viewing learning as a socio-cultural phenomenon, embedded in everydaylife practices. As De Weerdt et al. claim, a socio-cultural approach to learning:

- defines it as a holistic, identity-related process,

- emphasises its interactive, social features,

- locates it in a socio-cultural context,

- sees it as having a processual, lifelong nature (2002, p. 25).

There are, of course, numerous similarities between social capital and education, and the two are interrelated in many ways. Alheit (2010) aptly grasps them:

- Both capitals, social and educational (cultural), are very unevenly distributed.

- Both social capital and educational capital of the lower social strata are at a growing risk of being devalued.

- These factors, at work both in the economic sector and in the educational system, aggravate segregation processes and may bring about a split in late-modern societies.

Alheit insists that both social and educational policies urgently need to be informed by and promote, at the same time, a new political and moral commitment against tendencies towards segregation of this kind.

Undoubtedly, we are social animals. Society and the self are fundamentally intertwined, and we are social selves rather than self-contained individuals. As Burkitt argues, instead of dichotomising individual vs. social, we should try to see 
humans inside their essential connections with other people, people with whom we live and from whom we learn.

(...) society and the individual are not two separate entities, for humans are always in social relations from the moment they are born and they remain part of a network of other people throughout their lives. The fact that we feel isolated from others and, thus, from ourselves, says something about the type of social relations in which we live in the modern world, rather than anything about our essential nature as human individuals. (Burkitt, 1991, p. 2)

This resonates with the idea that the educational and developmental potential inherent in social capital can be a powerful resource in improving quality of life and the ability to think and act in ways that express authentic needs and help achieve lifefulfilment. As Burkitt says, human beings only develop as truly human within social contexts, but at the same time he states that certain types of social organisation can restrict the development of individuals through structural inequalities, ideological misunderstandings and wasteful social controls (p. 215).

How effective can social capital be as a learning resource? Could it be a miraculous 'cure for all', in much the same way that lifelong learning is sometimes seen? Given the versatile nature of different capitals, are they all equally useful in fighting serious social problems? How far (if at all) can we leave power relations out of the equation?

Relying on her long experience in researching and combating mass poverty, Else Oyen sees some serious limitations to the viability of social capital as a tool for reducing poverty. There are at least two reasons for that.

First of all, poor and non-poor people's social capitals differ substantially. Oyen claims that poor do not form the same kind of social capital, because they participate in different types of organizations, they tend not to be as active in political and civic life, and they have only restricted resources at their disposal. Their networks are more related to survival strategies, based on bartering, borrowing and lending goods, which creates symmetrical patterns of mutual expectations (Oyen, 2002). It does not take the scrutiny of extreme poverty cases to ascertain that social capitals clearly and undeniably differ in quality. As Peter Alheit (2010) notes, both an Aldi cashier and a young manager have their respective social capitals, but these are different capitals, because their value depends on their holders' position in the social order.

On the other hand, Prakash (2002) insists that even if poverty implies a lack of financial and human capital, it does not necessarily involve a lack of other resources. Social and natural resources are often crucial for survival, for overcoming risks to livelihoods, and for reducing the effects of natural and macro-economic shocks. According to Arrow:

The essence of social networks is that they are built up for reasons other than their economic value to the participants...Indeed, that is what gives them their value in monitoring. (2000, p. 4) 
Many researchers suggest that while the poor have abundant bonding social capital, they need more bridging and linking social capital to connect them to external actors and policy makers.

Secondly, beside the different natures of social capitals, another crucial issue is, according to Oyen, the accessibility of particular networks. Since the poor do not form and participate in the same organisations as the non-poor, they are barred from membership in non-poor people's networks. While exchange and reciprocity, next to trust, are the fundamental groundwork for networking and building social capital, what the poor can bring in rarely merits appreciation. In any network, a member is expected to contribute something, whether it be material or non-material resources. By definition, the poor may not have much to offer in the way of material resources to any non-poor network, and their non-material resources may not be much appreciated since they stem from a different background (Oyen, 2002, p. 14).

Poor people's absence from political and civic life, bound up with the process of social exclusion, further reduces their participation in non-profit forms of networking. They tend to assemble in search of the most efficient and accessible strategies for survival. When, occasionally, some poor interest groups are indeed formed to fight for a significant public good, they are usually controlled by the non-poor with their own agenda or as part of charity work. All the factors and mechanisms described above effectively constrain the potential of social capital as a feasible measure in reducing mass poverty. As Oyen points out:

The rosy picture that is presented of integration through social capital formation is in fact gloomy and unrealistic. If a majority of the poor are neither able to develop useful networks for increasing their own social capital on a large scale, nor given entry into those networks where social capital flourishes, how can social capital then be an efficient instrument for poverty reduction? (Oyen, 2002, p. 14)

This bleak conclusion does not mean that all efforts to increase poor people's social capital are either pointless or futile. Growth of social capital and improvement of its quality may and will serve not only the poor but also the whole society, even if that does not substantially reduce poverty. Much can be achieved through political and civil action (health, education, human rights, etc.), and it may lead to a redistribution of major resources, even though - as highlighted by Oyen - it may take a few generations to produce such outcomes. Oyen also believes in the transformative power of education, not - surprisingly - for the poor, but in particular for the non-poor, so that they can fully understand the nature of poverty with all its consequences and, thus, become more willing to open up their networks and integrate poorer members of society.

How difficult a task it may be - to successfully increase social capital of poor people lingering at the margins of the community - was borne out by the research conducted by Prakash (1998) in a small Himalayan village, in the region of Garhwal (Uttarakhand, India). The aim of his study was to examine institutional formation 
in the collective management of common-pool resources. The research concerned a forest the villagers planted with only little help from the government that granted legal use of land. Prakash's findings indicate that there were at least four different principles of fairness regulating distribution of both benefits and burdens involved in the use of the forest. Each form entailed different social relations and forms of investment in social capital.

These observations are described in Table 1. The first column shows the four principles of fair distribution that were adopted by the community at some point or other during the life of the institution: parity, which refers to equal distribution of benefits and burdens among all households; proportionality, that is, distribution of benefits in some relation to provision or burdens undertaken by each household; priority, or distribution of benefits and burdens according to need and capability; and prescribed, which refers to any principle determined by external agents (government agencies or aid donors) which the community is, as a rule, required to follow. The second column shows how social capital was typically invested in different forms of decision-making in order to arrive at an appropriate principle of fairness; the third column describes the typical attributes of the group, including symmetries in beliefs and interests as group relations changed over the course of successive management regimes; and the fourth charts the form of solidarity (based on Durkheim's classical formulation: mechanical solidarity-based or organic solidarity) present within each separate management regime or institutional type (Prakash, 1998, 2002, pp. 53-54).

Table 1. Four observed regimes for forest management in a Himalayan village

\begin{tabular}{|c|c|c|c|c|}
\hline $\begin{array}{l}\text { Institutional } \\
\text { type }\end{array}$ & $\begin{array}{l}\text { Norm of } \\
\text { fairness }\end{array}$ & $\begin{array}{l}\text { Investment of } \\
\text { social capital }\end{array}$ & Group attributes & $\begin{array}{l}\text { Form of } \\
\text { solidarity }\end{array}$ \\
\hline 1 & Parity & $\begin{array}{l}\text { Coalition } \\
\text { building }\end{array}$ & $\begin{array}{l}\text { Homogeneous } \\
\text { beliefs and interests }\end{array}$ & Mechanical \\
\hline 2 & Priority & $\begin{array}{l}\text { Selections } \\
\text { from } \\
\text { precedents }\end{array}$ & $\begin{array}{l}\text { Shared beliefs, } \\
\text { asymmetric } \\
\text { interests }\end{array}$ & Organic \\
\hline 3 & Proportionality & Bargaining & $\begin{array}{l}\text { Heterogeneous } \\
\text { beliefs and interests }\end{array}$ & Organic \\
\hline 4 & $\begin{array}{l}\text { Externally } \\
\text { prescribed }\end{array}$ & Ineffective & -------------------- & Mechanical \\
\hline
\end{tabular}

Source: Prakash, 1998

Prakash notes that such self-governing collective institutions and regimes reflect the form of the society in which they are embedded. As a result, any kind of interference by funders, government agencies or NGOs with the collective processes through which local communities invest social capital in collective management (for instance, and most typically, by prescribing a regime of equal distribution of 
benefits) can lead to a serious decline of social capital within the community and make future collective endeavours more difficult.

It is a serious threat, but it is - according to Prakash - a common-sense one. The process of negotiating individual households' contributions and benefits with respect to the collective management of the common-pool resource is, as he explains:

... precisely the process wherein the community's stock of social capital is invested. Clearly, such cooperative, collective management needs to succeed in order for local stocks of social capital to develop and eventually to be reinvested in other, future joint endeavours. (Prakash, 2002, p. 55)

Concluding, social capital can be a powerful resource when used advisedly, but those who believe it is an easily accessible panacea for poverty (and other social problems of the modern world) may be disappointed. As Prakash's research shows, external meddling with social capital and the way it is originally understood and built within a particular community may be not only ineffective but also detrimental to the existing bonds and trust among people. It takes sensitivity to and critical awareness of not only the cultural differences, but also the power tensions between the helpers and the helped, to successfully deploy social capital.

This calls for a more critical approach both to the concept of social capital and to the concept of learning alike, as they are both embedded, according to Alheit (2010), in the dominant structures of power and governance.

The delusion of a lifelong learning society does nothing whatsoever to eradicate the selection and exclusion mechanisms of the 'old' educational system. Indeed, it may conceal and exacerbate those mechanisms instead. (p. 39)

He claims that reproduction of social inequalities through cultural and educational practices is inevitable as long as there is no balance in terms of investment in social and economic capitals. With no such balance in place, education not only fails as a resource for life improvement but also turns into an instrument of the economic regime of productivity, utility and employability. Unsurprisingly, it weakens social confidence and trust or, to use Putnam's phrase, it 'puts moratorium on solidarity' (Alheit, 2010, pp. 39-40).

Therefore, social and critical underpinnings of education must be enhanced to enable learners to identify, challenge and change the status quo based on unexamined beliefs and assumptions that can and should be interrogated. One way to achieve that can be through applying a critical approach to adult learning.

According to Brookfield, adult learning features prominently in critical theory, in which creating a democratic society, watchful for manifestations of injustice, inequity and oppression, is viewed as a series of learning tasks. The crucial tasks include learning to recognize and challenge ideology, learning to uncover and counter hegemony, learning to unmask power, learning to overcome alienation and accept freedom, learning to pursue liberation, learning to reclaim reason and learning to practice democracy (Brookfield, 2009, p. 39). 
A critical approach to adult learning makes it possible to investigate crucial aspects of democratic citizenship and its challenges such as: how adults become aware of and learn to live with the contradiction of freedom and democracy and contingency of the democratic process? What are the conditions for participation in democratic discourse? How do adults learn to respond to "otherness," diversity of means, values and identities? How do they learn the art of dealing with distortions produced by disproportionate power distribution? How do they learn to reflect critically on social practices that constitute democracy? (Brookfield, 2009, pp. 64-65).

Thus, critical learning might provide an opportunity posited by Alheit's observation on the interconnectedness of education and social capital and posing a key challenge to be faced in the future:

If we want to consider a productive interaction between lifelong learning and social capital, then we must also consider not only the educational but also the political dimensions. (Alheit, 2010, p. 44)

Another interesting option might be found in narrative learning and its potential to explore social aspects of the agentic processes captured while re-constructing one's life history. According to Tedder and Biesta, narrating one's life story can therefore be understood as an act of constructing a self, where the self is not only an object or a product of the narrative, but at the very same time the subject of narration. Rather than just the outcome of a learning process, narration can be seen also as (narrative) learning-in-action (Tedder \& Biesta, 2009, pp. 21-22).

The crucial aspect in narrating one's life is the provision of social settings in which such stories can be told to others and constructed with others in order to ensure communicative evaluation and imaginative distancing. And political aspects are intrinsically entangled with the questions about the 'quality' of settings and interactions.

Many authors have commented on the 'individualisation' of adult learning and, more importantly, on the de-politicising effects of this individualisation (see Martin, 2003; Biesta, 2006b), i.e., the loss of opportunities to translate 'private troubles' into 'public issues' (Wright Mills). Supporting narrative learning is therefore neither only about improving people's 'capacity' for narration, nor only about providing opportunities for doing this together with others. What matters is also the extent to which such learning processes can be understood in a political way and can be lifted from the level of private troubles to the plane of public and political issues, so that the learning economy might eventually transform into a 'learning democracy' (Tedder \& Biesta, 2009, p. 33).

Social aspects of everyday practice are an important component of learning, as many adult learning researchers underscore. Similarly to learning itself, its social dimensions are multifaceted and multilayered. It may become a powerful resource to enhance our functioning in the world and improve the quality of our lives. However, it may also thwart our development by entrapping us in the vicious circle of unreflectively reproduced socialization patterns. Certainly, social learning resources, 
when augmented by political perspectives and critical thinking, may trigger social change. We must keep in mind, nevertheless, that, as Jarvis pithily noted, 'learning is both at the heart of social conformity and also at the heart of social change.'

\section{REFERENCES}

Alheit, P. (2010). Lifelong learning and social capital [Keynote speech from the 3rd conference of the ESREA Network 'Local in Global', Magdeburg 28-30 May 2009]. In R. Evans (Ed.), Local development, community and adult learning - Learning landscapes between the mainstream and the margins (Vol. 2, pp. 27-49). Duisburg, Germany: Nisaba Verlag.

Arrow, K. (2000). Observations on social capital. In P. Dasgupta \& I. Serageldin (Eds.), Social capital: A multifaceted analysis. Washington, DC: The World Bank.

Brookfield, S. D. (2005). The power of critical theory for adult learning and teaching. New York, NY: Open University Press.

Burkitt, I. (1991). Social selves: Theories of the social formation of personality. London, England: Sage Publications.

Oyen, E. (2002). Social capital formation: A poverty reducing strategy? In Social capital and poverty reduction: Which role for the civil society organizations and the state? (pp. 11-15). Paris, France: UNESCO and CROP.

Prakash, S. (1998). Fairness, social capital and the commons: The societal foundations of collective action. In M. Goldman (Ed.), Privatizing nature. London, England: Pluto Press.

Prakash, S. (2002). Social capital and the rural poor: What can civil actors and policies do? In Social capial and poverty reduction: Which role for the civil society organizations and the state? (pp. 45-58). Paris, France: UNESCO and CROP.

Tedder, M., \& Biesta, G. (2009). Uczenie sie bez nauczania? Potencjal i ograniczenia biograficznego uczenia się doroslych (Learning without teaching? Opportunities and limitations in biographical learning for adults). Terazniejszosc-Czlowiek-Edukacja, 2(46), 19-35.

Adrianna Nizińska

University of Lower Silesia

Wroctaw, Poland 



\title{
9. "WHY CHOOSE ONE HAND OVER THE OTHER WHEN WE CAN USE THE BEST OF TWO?"
}

\author{
Adult Educators' Perspectives on Adult Education
}

\section{A SHORT JOURNEY IN ADULT EDUCATION IN PORTUGAL}

The adult education tradition in Portugal is mainly characterized by its absenteeism, due to political and financial disinvestment, and also as a result of one of the longest authoritarian regimes in Western Europe, lasting from 1926 until 1974, which profoundly affected Portuguese people's access to education. This conjunction of factors led to the existence of a massive group of active adults (i.e., at working ages) who weren't able to finish their basic education, i.e. the current first cycle (4 years of schooling), the second cycle (6 years of schooling), the third cycle (9 years of schooling) and the secondary level of education (12 years of schooling).

The significant number of poorly schooled adults, which totalled 3.5 million in 2005 - of which a stunning 2.6 million did not complete nine years of schooling ${ }^{1}-$ posed at least two kinds of problems from a European Union membership perspective. Firstly, it conflicted with its foundational goal, to become "the most competitive and dynamic knowledge-based economy in the world"2 and on the other hand, it revealed the low qualification levels of the Portuguese workforce when compared to its EU peers.

Nevertheless, after a long history of truancy and due to a considerable financial investment provided by the European funding, which included adult education as one of its priorities, there was a significant development of initiatives between the years 2000 and 2012 that boosted this domain in various ways, which we have tried to summarize in Table 1.

Table 1 allows us to identify two key periods in the recent history of adult education in Portugal: a decade in which the New Opportunities initiative became the most significant, the most participated in and politically discussed adult education program in Portugal, enrolling 7572 professionals in pedagogical teams ${ }^{5}$ ("adult educators" from this point on); and in 2012, along with the formation of a new government, the creation of the National Agency for Qualification and Vocational Education and Training, which marked a new shift in public policy on adult education. These recent revisions included: 
Table 1. Adult education tutelary entities and their missions (Portugal, 1999-2012)

\begin{tabular}{|c|c|c|c|}
\hline $\begin{array}{l}\text { National agency } \\
\text { for adult education } \\
\text { (1999-2002) }\end{array}$ & $\begin{array}{l}\text { General } \\
\text { directorate } \\
\text { of vocational } \\
\text { training } \\
(2002-2006)\end{array}$ & $\begin{array}{l}\text { National agency for } \\
\text { qualification } \\
(2006-2012)\end{array}$ & $\begin{array}{l}\text { National agency } \\
\text { for qualifications } \\
\text { and vocational } \\
\text { education } \\
\text { and training } \\
(2012-\ldots)\end{array}$ \\
\hline $\begin{array}{l}\text { Creation of the } \\
\text { National System } \\
\text { of Recognition, } \\
\text { Validation and } \\
\text { Certification of } \\
\text { Competencies and } \\
\text { the national network } \\
\text { of Recognition, } \\
\text { Validation and } \\
\text { Certification of } \\
\text { Competencies } \\
\text { (RVCC) Centres }\end{array}$ & $\begin{array}{l}\text { Continues the } \\
\text { previous work } \\
\text { and integrates } \\
\text { Vocational } \\
\text { Training, } \\
\text { broadening the } \\
\text { scope of its } \\
\text { mission to young } \\
\text { people }\end{array}$ & $\begin{array}{l}\text { Implementation } \\
\text { of the New } \\
\text { Opportunities } \\
\text { initiative, which } \\
\text { enrolled more } \\
\text { than } 1 \text { million } \\
\text { participants in } \\
\text { education and } \\
\text { training processes, } \\
\text { and contributed to } \\
\text { the expansion of } \\
\text { New Opportunities } \\
\text { Centres }\end{array}$ & $\begin{array}{l}\text { Creation of the } \\
\text { Qualification } \\
\text { and Vocational } \\
\text { Education } \\
\text { and Training } \\
\text { Centres }^{4} \\
\text { reorganizing } \\
\text { the network } \\
\text { and redefining } \\
R V C C\end{array}$ \\
\hline
\end{tabular}

- the reunification of adult education and general vocational education, meaning the mixture between different education and training devices and target populations under the same governing body;

- the re-baptism and reconfiguration of the previous New Opportunities Centres, which are now aimed at a population over 15 years old, therefore losing their specificity as a "gateway" for adult education (e.g., Simões \& Freire, 2008, p. 9), and a reframing of the RVCC within the school model by, inter alia, devising a model for competencies assessment through tests and examinations;

- the suspension of the provision in adult education, justified by the necessity to generate regulatory legislation, which has significantly delayed its implementation, so much that even now, as we write, there are very few Centres which are fully active.

This bring us to the main concern of this text, which focuses on the professionals enrolled in the New Opportunities initiative, and the way they conceived their roles as adult educators, concentrating on the philosophies of learning they conveyed. The importance of this object of study lies in the fact that due to the great expansion of the New Opportunities initiative, there was, back in 2012, a significantly larger number of professionals involved in adult education in Portugal than there had been one or two decades ago. These professionals were spread across various functions, including teaching, mediation, recognition, validation and certification of competencies, and/ or pedagogical coordination. They also demonstrated different characteristics when 
compared to their predecessors (teachers of second chance education): ${ }^{6}$ many of them had graduated from college in areas related to social sciences and humanities, there was a feminization of the professional sector, they were younger, and many of them had little previous experience in adult education (Guimarães, 2009). Another interesting feature was that these adult educators performed their activities under two major administrations: the state sector and its system of education and training, and the private sector and non-profit organizations, particularly those related to community and local development (Loureiro \& Cristóvão, 2008).

Abundant literature in the field of methodology considers that "adult education in the context of post modernity may have lost some of its foundational certainties but it has also enabled a fuller range of adult learning practices to emerge" (Edwards \& Usher, 2006, p. 58). Merriënboer and Stoyanov (2008) propose an agenda that involves adapting the methods of instruction to a learning landscape that faces rapid changes, which is the current context. In short, in the end, everything comes down to a matter of choice, and the beliefs that support it. But these are hard choices to make, to the extent that the available options are dissonant and there are no choices without consequences. In this universe of theories that are not confluent, which way should the adult educators follow? Who/what gives them the security and guidance they need to work with?

\section{THE CONCEPTUAL AND METHODOLOGICAL FRAMEWORKS OF ADULT EDUCATORS}

Those who are working in the domain of social sciences are accustomed to observe, and even appreciate, lively debates and theoretical discussions as a sign of vitality of a discipline. In a distinctive way, for politicians and technicians - as for instance those in adult education organizations - the unequivocal nature of the guiding principles is seen as synonymous with competency and authority, as they grant directionality and safety to actions taken in order to accomplish what is expected from them. However, within the context of a rising and developing system of policies and practices in adult education, such as the one we have witnessed in Portugal in the period 1999-2012, these guiding principles are subject to a complex questioning: how to deal with the ambiguity of the options, which, at their core, confront the importance of lifelong learning in informal and non-formal contexts, with the importance and tradition of formal learning institutions and frameworks?

From an academic perspective, and certainly without aspiring to reduce the richness of the debate to a simple dichotomy, we could affirm that the most important theoretical distinction within the philosophies of learning, when trying to interpret the complex process of learning - amid the contributions of such authors as John Dewey, Paulo Freire, Ivan Illich, Jack Mezirow, Donald Schön, or Peter Alheit, among others - is the focus on internal and psychological processes of knowledge acquisition and learning and, alternatively, the emphasis on the influence of the social, cultural or material (structural) context in the processes of learning (e.g., Illeris, 2009). 
In the first perspective, the transformative nature of learning stems from the way in which the adult critically (re)produces the mechanisms of (self) identification, validates them through discursive interaction with others and reflexively faces the challenges of a "risk society", increasingly future-minded (Giddens, 1990). Accordingly, experiential learning does not only lead to new knowledge, capacities, skills and attitudes, but also gives way to the construction of self (Jarvis, 2007), as well as the consolidation, by the individual, of a critical awareness about him/herself and about the surrounding reality (Mezirow, 2009). Distinctively, a liberating and militant perspective of adult education interprets the process of learning as a socially constructed activity, as part of a process of dialectical and critical analysis of societal forces that perpetuate inequalities and, consequently, views education tools as liberating and conscientizing instruments for individuals to break those forces and ideologies that impede their emancipation (Freire, 1997).

Both lines of thought have fragilities and limitations. In the case of the most functional approaches to education, one of the most evident criticisms that can be levelled is the way such approaches militate for a transformation of the individualized subject, pressuring him/her to adapt to new circumstances, by relating to a liberal agenda that aims to make the individuals increasingly flexible and competitive in the labour market. The criticism clearly denounces the transfer of institutional (school and state included) demands onto the individual, who becomes an autonomous subject, with prime responsibility for his or her own fortune. In the case of the most critical perspectives of education, the criticism is expressed around the way personal change is associated with the transformation of the social macrostructures, the success of which depends on the emergence of a new political, economic, cultural and social order. This process can only be attained by being clear about the course to take, in the face of conceptual pillars of society which are no longer more than "zombie categories" (Beck, 2002), and this, clearly, calls for well-informed and critical subjects.

This dichotomy could be overcome through a comprehensive vision, in favour of a capacity to connect "personal troubles" with "public issues" (Sutherland \& Crowther, 2006, p. 3) and to understand the relationship between the two. From a perspective which includes building comprehensive models that guide adult education, we can affirm that the debate is still alive and it's characterized by contrasting positions (Gomes \& Monteiro, 2011). In opposition to this, for those who have just recently come into contact with this reality, or (especially) those who are enrolled in the implementation of concrete adult education initiatives, the discourse that comes to them seems to be relatively uniform and consensual: knowledge societies, competitiveness and skills, vocational profiles, individualized and self-directed learning - these are some of the terms that frame a view of adult education essentially concerned with the qualification of large populations, in order to achieve goals that are measured by the number of subjects involved and the number of qualifications awarded or recognized. 
When observing the political and technical answers to the challenge of adult education, the first reflection is that pressured by the market, the national States have responded with an agenda that seeks to integrate the dimensions of innovation and knowledge as part of their competitive advantage. In order to achieve such goals, it is essential to bring back to the educational system those who left it early and now face problems of employability. Similarly, it gave rise to an interesting and lively debate about how to recognize and include the non-formally acquired knowledge in adult education, leading to the conviction that we are facing a "paradigm shift" in education. Following the Lisbon Treaty, the European Union set the target of reaching a $12.5 \%$ rate of adult participation in lifelong learning. Following this benchmark, the New Opportunities Initiative in Portugal set itself one ambitious target: involving one million people in this initiative. Through a large effort of mobilization of resources, structures, and professionals, it became possible, in the space of four years, to involve (reportedly) 1088316 unemployed and employed adults who had not completed secondary education (as of September 2010) in Recognition, Validation and Certification processes or in Adult Education and Training courses.

The main methodological guidelines inscribed in the Key-Competences Frameworks which have grounded the adult education model in progress, advocated an approach which was (auto)biographical:

The appreciation of the (auto)biographical perspective in the processes of adult training emerges in the context of progressive rehabilitation movements of the subject (...). Using this method in the process of [Recognition, Validation and Certification of Competences] has also the value of (re)focusing the attention (...) in [the candidate to certification], in his experience and life path. It allows the deconstruction of social representations, stereotypes, mediating the [redefinition of life projects], perhaps fragmented, making the facts reported more intelligible, in a friendlier and closer style than those which candidates eventually use in their day-to-day [lives]. (Gomes, 2006, p. 29)

Still, this is sufficiently vague to accommodate different methodological solutions and demands for decision-making processes. It can either lead to an individual and utilitarian orientation that emphasizes vocational training, or it can be open to solutions that are grounded in looking at adults as critical subjects who should be actively participating in the construction of their identity and personal projects, simultaneously becoming community members and citizens of the polis.

THE DILEMMA: BETWEEN THE "RIGHT” AND THE “LEFT HAND” OF LIFELONG EDUCATION

The course Adult Education and Training Routes: Recognition, Validation and Certification of Competences was promoted by the Faculty of Psychology and 
Educational Sciences of the University of Porto between the years 2005 and 2011, and its main goal was to engage adult educators in a learning context where pedagogical strategies could be shared, experimented and developed, and critical reflection about the theories and practices in adult education could be undertaken. The developments in Portuguese adult education during that period and also the demands voiced by the participants in various editions of this course determined its division into two sets: the basic and the advanced versions. The first was designed for people with no experience in adult education, and the second for those who already had previous practice and/or knowledge in the domain. It involved 30 hours of face-to-face training, divided into 10 sessions of three hours each.

In the advanced version of the course, and as a final activity, the participants delivered a paper in which they reflected upon Licínio Lima's book (2007a, 2007b) entitled "Educação ao Longo da Vida. Entre a Mão Direita e a Mão Esquerda de Miró" ("Lifelong Education. Between Miró's right and left hand"). In this book, the author explains how the confrontation with a poem written by the Brazilian writer João Cabral de Melo Neto (1997, cited in Lima, 2012) ${ }^{7}$ led him to develop an argument consisting in the assumption that there is a continuum between an "economicist, managerialist and technocratic" - the "right hand" - and a "humanistic and critical" lifelong education - "the left hand" (Lima, 2012, p. 137).

Lima assumes that the "multiform" nature of the concept and practices of lifelong education imply a comprehensive understanding which must include both sides of the previously discussed trends in education policies and proposals: the "right hand" representing the most pragmatic, functional and purely adaptive education, and the "left hand" expressing the critical, developmental and radical approaches. The author argues for the existence of complex situations that should integrate both hands and the correspondent tensions, suggesting the coexistence of diverse paradigms and options in an "ambidextrous lifelong education" (Lima, 2007b, p. 87), which benefits from the potentialities of both "hands". There, the author integrates the tensions between human "adjustment and transformation" (Lima, 2010, p. 48):

- it would be naïve to expect that education could provide pure adjustment to economic and functional needs - and be reproductive of the dominant ideology (Freire, 1997), in its "right hand;"

- but it would also be an incomplete reasoning if we considered that education could be the sole and powerful key to social transformation and the basis for the construction of cohesive societies functioning under the motto of solidarity - as it was considered in the foundation of UNESCO, and in the idea of a permanent education (Gomes \& Lucio-Villegas, 2009), in its "left hand."

In fact, it is this tension that feeds the search for, and the constitution of, a democratic education which can disrupt the pedagogism of technocratic lifelong learning approaches and integrate the "substantivity of life along the learning" experiences and processes, affirming the undeniable and inescapable "active participation of learners in the [ir own] educational process" (Lima, 2010, pp. 51-52). 
In the same way, the "protagonism attributed to the right hand or to the left hand of lifelong education" (Lima, 2007b, p. 94) has different consequences in the way the adult educator is considered: as an executioner of the norms imposed by the functionalist ways of lifelong education, or as the critical friend who creates the optimal conditions for learners to undertake a reflexive dialogue with reality in order to understand different power relationships and act upon them autonomously. However, this last option implies "assuming an identity of a reflexive practitioner", which "might cause irritation, (...) irony, controversy, lassitude, marginalization", because it conflicts with the "mechanisms of protection that [one] developed" during one's experience as a student and with the "social norms [ruling] in all forms of training or work" (Perrenoud, 2005, pp. 30-31).

As in the deadlock situation of Miró in the poem, so are the adult educators struggling for answers about the right (or the best) adult education policies, perspectives, and strategies. Do they critically (and reflexively) undertake these questions in the course of their everyday practice? Do they conscientiously choose the "hand" with which they work? Where do they actually position themselves? These were the questions that guided our research, fundamentally related to Lima's book: we asked some of these adult educators where they stood in this reflection. In sum, we tried to capture the adult educators' philosophical, ideological and/or practical dilemmas in a context of emergence and development of an adult education "system" in the particular Portuguese context.

\section{METHODOLOGY}

The discursive material that was under analysis in this research was the response of the participants in the Adult Education and Training Routes: Recognition, Validation and Certification of Competences course to the question: what about me, where do I stand between Miró's right and left hand (as far as adult education in concerned)? For this particular research we analysed 35 papers of the participants from three different editions of the course, developed between May 2008 and November 2009. In this group of participants, there were 26 women and 9 men, with different backgrounds concerning their initial training and their experience in adult education - there were, for instance, people with degrees in Social Education, Psychology, Education, Human Resources, History, Mathematics, Geography, and Sociology. Taking into account the motto for discussion, we analysed the texts in order to identify the emerging categories from adult educators' discourse when facing the reflexive task of positioning themselves in a "right-hand/left-hand" metaphor, which implied the revision of their own practices and concepts of adult education.

The methodology used in the analysis follows the proposal of Demazière and Dubar (1997, p. 34), defined by the authors as an "analytical approach that seeks to methodically produce a sense from the exploration of research interviews". The authors have structured an approach to the subjects' discourse (oral or written) which is essentially inductive and analytical, with strong affinities to the grounded 
theory developed by B. Glaser and A. Strauss (e.g., Heath \& Cowley, 2004), aimed at building theory from an intensive case analysis and characterized by a continuous comparison of empirical data. The inductive process of theorizing is defined through three major operations:

- A first operation of translation/nomination, in which the collected data are translated into memos and analytical categories, necessarily provisional. By comparison, the individual discourses are translated, classified and added up following convergence and dissociation logics.

- The second operation allows the withdrawal from the original data (raw material) and a process of structuring the categories in a more coherent and integrated system of hypotheses. The irrelevant properties are eliminated, there is an initial saturation, and tuning up relationships between categories and concepts are formulated.

- The last operation will lead, through processes of conceptualization and abstraction, to the formulation of theoretical propositions endowed with logical consistency. Through comparative analysis of discourses and their categorization, individual and subjective data are transformed into more formal and abstract categories that give meaning to the "sociological subject" on which the research focuses.

\section{THE AMBIGUITY OF CHOICES: “...I AM AMBIDEXTROUS!” (IV-4: 1)}

Working upon the texts produced by the 35 participants of the course, we isolated three emerging categories of analysis that the majority of the participants pointed out in order to explain their reflections on the motto: (1) concept of the current state of adult education; (2) references to their professional experience in adult education; and a (3) prospective vision of adult education.

\section{Concept of the Current State of Adult Education}

The 21 participants who reflected on this subject tend to emphasize how current adult education defies the traditional school, depicting it as a "counter-school education" and evidencing the tension between the two kinds of educational provision:

school, in its classical version, (...) [doesn't accept] other forms of learning, its past would call it monopolist of knowledge and training (...) more and more (in)formation and transmission of knowledge (...) updated in many other institutions (...) lack of openness of the schools. (III-17: 7)

Nevertheless, it is also evident that adult education is considered to be "minor" when compared to formal education. These opinions confirm the widespread perspectives which point out that in some European countries, the profession of adult educator is seen to be of low status and low attractiveness (Research voor Beleid \& PLATO, 2008). 
A group of participants chose to highlight the new challenges that adult education posed to its stakeholders: challenging the educator's role, the centrality of the adult learner, the relationship between both parties, and the incorporation of new knowledge and competencies. Some participants value the power of support and guidance that theories can give throughout this challenge, and the importance of balancing their possibilities:

the different times, spaces and actors, assumed in a continuum of positions, ideally combined $(.$.$) an "ambidextrous" education that combines and$ integrates diverse knowledge. (III-16: 3)

Nevertheless, one idea seems to emerge recurrently: adult education is considered to be a field under construction and subject to change, even though there are diverging opinions about which direction should be followed.

\section{Experience in Adult Education}

Those who opted to mention this subject, underline this experience as being lived as a challenge, but most of all as a conflict:

The conflict that was [inherent] to my performance was related to [choosing] an option: taking refuge in the knowledge and methodologies available, continuing the techniques already in place; or daring to reshape the process, granting adults the [decision about] the way to follow? (III-11:2)

...all of this was (...) tiring, unattractive and (...) poorly motivating. Is a teacher just that? A curriculum manager, an 'obedient doer' of the instructions issued by the authorities? (IV-5: 1)

In most circumstances, this conflict was described as the result of a confrontation between what they had learned in their initial training, what they apprehended in the course of their professional practice, and reality as it is, in their daily working life as adult educators. On the other hand, most participants indicated that the resolution of this conflict was sought through the adaptation of strategies to circumstances, even though some characterized it as an unsolved problem:

... I don't feel wise or capable of inventing. (III-4: 2)

... I don't feel my hands building, instead they are contributing to apathy. (III-6: 5)

... I do recognize I sometimes 'suffer' from major shortages and limitations... (III-8:2)

The challenge provoked by the reading of Licínio Lima's text had a direct response from thirty adult educators. The ambidextrous nature that the author considers possible and desirable to imprint on the project of a lifelong education receives almost full agreement from the participants in this exercise. Moreover, 
most of them admit to having already put it into practice in their professional performance:

Therefore, my positioning is ambidextrous... (IV-3: 1)

I place myself sometimes in the left hand, sometimes in [the] right hand. (II-1:2)

Every day I face situations in which I have to balance both my hands, it's necessary to be wise (...) it's a continuous struggle this fragile balance... (III-14: 1)

However, if the dominant tendency is to share this proposal, it is not so much like that when it comes to realizing that making choices raises tensions, which are difficult to resolve, or to the critical consideration of the risks that these choices entail. Most of the participants chose not to incorporate the dissonances and tensions between human "adjustment and transformation", and highlighted the advantages of combining the best of both worlds:

Why choose one [hand] over the other when one can use the best of two? (III-3: 6)

\section{Prospective Vision of Adult Education}

Some of the texts deliver clues about the possible and desirable future of adult education, suggesting the individualization of training paths, and providing autonomy and responsibility to the learners, which appear to be the main ideas:

Maybe the adult[s] wish to see a reality of teaching/learning copied from those which [they] already know, and what I give [them] is an alternative that I believe is best. But even if it is, don't [they] have the legitimacy to choose the strategies [they] know? Am I confusing what [they] want with what I [think they] want? Or am I to deprive [them] of opportunities of development, for wanting [so] badly to simplify the process? (II-6: 7)

Simultaneously, there is a similar tendency toward consensus regarding the (re)configuration of the figure of the educator/trainer as a learning facilitator, manager of diversity, coach, motivator, and promoter of opportunities for development. The future of adult education is also a theme for debate between crossover visions offered in the training of autonomous and responsible subjects, and other visions which are more interested in putting adult education at the service of an agenda of social change. Yet, the first perspective seems to receive greater agreement from these adult educators.

The novelty and recency of this adult education framework is consistently referred to, as both a potentially positive and negative element of the decision-making process. In the first case, it allows for a wider range of choices, more creativity, higher adequacy to the training needs of adults, and the broadening of the adult educator's role, who becomes the co-builder of the qualification alongside the adult 
learner. The second, negative reference relates to the instability of the model due to its early life, the constant production and publication of new policies and guidelines, the uncertainty as to the strategies and methodologies, and finally the fear of risk. To facilitate learning, as opposed to classical instruction, is, in a way, to be exposed by giving power back to the learners, giving them space for questioning and acting, assuming the bi-directionality of the act of learning. Therefore, it means to take the risks associated with experimentation and sharing, which bring in uncontrolled elements, and make room for uncertainty in decision-making.

Adult educators who were socialized in the school model may eventually pose more resistance to assuming their role as facilitators, while those who have graduated from other models closest to the vocational and training approaches may feel more comfortable in this role. However, the discourses of our respondents systematically identify the tension between both perspectives, regardless of their career, thus suggesting that this ambiguity may be inherent to the action of adult educators.

\section{FINAL REMARKS: USING THE BEST OF TWO HANDS}

If we expected to find evidence of a dilemma or conflict between perspectives that are contrasting and often conflicting among adult educators in Portugal, this is not exactly what we found. We didn't detect a clear awareness of the consequences of making choices. This might give meaning to the hypothesis that we are confronted by a largely uncritical positioning which is only partly supported by systematic thought, and which isn't consciously considering the distance between the options at stake and the consequences that choices entail in terms of perspective, strategy and instruments. We obviously formulate this hypothesis as a path for our work to take. Other voices and testimonies would be needed, and further analysis is necessary to provide deeper insight into this problematic.

Nevertheless, we can claim that there is a clear predisposition among these adult educators for change: reading Lima's text and reacting to the motto was somewhat uncomfortable, but above all stimulating. Most of them think that adult education is challenging and disruptive, even though it's still not recognized in its importance at the level of the formal devices and systems - it calls for new competences of the educator, for a new vision of the learner, for the reconfiguration of the relationships between the agents, and for new knowledge and development of innovative strategies. Alongside the challenge, comes conflict - between what was previously learned, and the new ways of learning, which call adult educators to redefine their role as facilitators, mediators, and creators of opportunities for individual development.

This point is actually one recurrent and revealing aspect of the data analysed in the present research. It is very clear that choosing between, or trying to complement, different approaches to adult education which are sometimes contradictory, and that 
imply assuming a role which is different from the educator's role in which most professionals have been socialized, ultimately demands the courage to expose oneself, balancing the old and the new, the secure and insecure, the controlled and the unforeseen.

From this analysis, it seems to us that there are still various challenges for adult educators, which might benefit from: encouraging the debate about, and understanding of, alternative scenarios, expanding the discussion to other contexts and stakeholders, and promoting action-research opportunities, which might stimulate reflective and critical practices. Given the current situation in Portuguese adult education, which seems to be in a standby phase, it would be an optimal moment for reflecting on the issues raised in this chapter, and wondering - essentially - whether adult education can actually survive the scarcity of critical adult educators who are able to use the best of both "hands of lifelong education".

\section{NOTES}

Data retrieved from: http://www.oei.es/quipu/portugal/novas_oportunidades.pdf

Retrieved from: http://www.europarl.europa.eu/summits/lis1_en.htm

Previously known as Recognition, Validation and Certification of Competencies Centres.

Previously known as New Opportunities Centres.

Source: National Agency for Qualifications, 2012.

6 This provision refers to the so-called "night-school", which adults can attend in order to proceed with their studies. In short, it's the same curriculum of the regular school, but it allows students to define the pace of their tests and examinations.

7 Here we quote the poem translated into English from its original Portuguese version (Lima, 2012: 140):

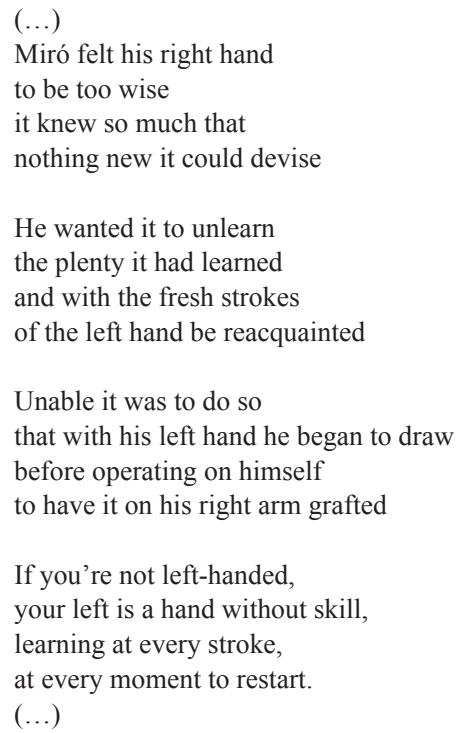




\section{REFERENCES}

Beck, U. (2002). Zombie categories: Interview with Ulrich Beck. In U. Beck \& E. Beck-Gernsheim (Eds.), Individualization: Institutionalized individualism and its social and political consequences. London, England: Sage.

Demazière, D., \& Dubar, C. (1997). Analyser les entretiens biographiques: L'exemple des récits d'insertion. Paris, France: Nathan.

Edwards, R., \& Usher, R. (2006). A troubled space of possibilities: Lifelong learning and the postmodern. In P. Sutherland \& J. Crowther (Eds.), Lifelong learning: Concepts and contexts. London, England: Routledge.

Freire, P. (1997). Pedagogia da autonomia: Saberes necessários à prática educativa. São Paulo, Brazil: Paz e Terra.

Giddens, A. (1990). Consequences of modernity. Cambridge, England: Polity Press.

Gomes, I. P., \& Lucio-Villegas, E. (2009). Recognition of lifelong and lifewide learning within the scope of permanent education: A new pathway towards citizenship? In E. Lucio-Villegas (Ed.), Citizenship as politics: International perspectives from adult education. Rotterdam, The Netherlands: Sense Publishers.

Gomes, I. P., \& Monteiro, A. (2011). The landscape changes when we alter the perspective: Envisaging new ways of looking at old problems through learning relationships with adults. In A. Fragoso, E. Kurantowicz, \& E. Lucio-Villegas (Eds.), Between global and local: Adult learning and development. Frankfurt am Main, Germany: Peter Lang.

Gomes, M. C. (Coord.). (2006). Referencial de Competências-Chave para a Educação e Formação de Adultos - Nivel Secundário: Guia de Operacionalização. Lisboa, Portugal: Direcção-Geral de Formação Vocacional.

Guimarães, P. (2009). Reflections on the professionalization of adult educators in the framework of public policies in Portugal. European Journal of Education, 44(2), 205-219.

Heath, H., \& Cowley, S. (2004). Developing a grounded theory approach: A comparison of Glaser and Strauss. International Journal of Nursing Studies, 41, 141-150.

Illeris, K. (Ed.). (2009). Contemporary theories of learning. New York, NY: Routledge.

Jarvis, P. (2007). Globalization, lifelong learning and the learning society: Sociological perspectives. London, England: Routledge.

Lima, L. C. (2007a). Educação ao longo da vida: Entre a mão direita e a mão esquerda de Miró. São Paulo, Brazil: Cortez.

Lima, L. C. (2007b). Políticas de formação ao longo da vida. Actas do IX Congresso Nacional de Centros de Formação de Associação de Escolas. Retrieved January 12, 2011, from http://pt.scribd.com/ doc/2667628/Politicas-de-Educacao-e-Formacao-ao-Longo-da-Vida

Lima, L. C. (2010). A Educação faz tudo? Crítica ao pedagogismo na "sociedade da aprendizagem". Revista Lusófona de Educação, 15, 41-54.

Lima, L. C. (2012). On the right hand of lifelong education. In R. Arnold (Ed.), Entgrenzungen des Lerners: Internationale Perspektiven für die Erwachsenenbildung. Bielefeld, Germany: Bertelsmann Verlag.

Loureiro, A., \& Cristóvão, A. (2008). A relação dos técnicos de educação de adultos com o discurso pedagógico oficial: um caso a Norte de Portugal. Educação \& Sociedade, 29(105), 1113-1135.

Merriënboer, J., \& Stoyanov, S. (2008). Learners in a changing learning landscape: Reflections from an instructional design perspective. In J. Visser \& M. Visser-Valfrey (Eds.), Learners in a changing learning landscape. Florida, FA: Springer.

Mezirow, J. (2009). An overview on transformative learning. In K. Illeris (Ed.), Contemporary theories of learning. New York, NY: Routledge.

Perrenoud, P. (2005). Assumer une identité réflexive. Éducateur, 2(18), 30-33.

Research voor Beleid \& PLATO. (2008). ALPINE - Adult learning professions in Europe: A study of the current situation, trends and issues: Final report (Project number B3276). Zoetermeer, The Netherlands: Research voor Beleid. 


\section{GOMES \& A. A. MONTEIRO}

Simões, M. F., \& Freire, M. V. (Coord.). (2008). Metodologia de acolhimento, diagnóstico e encaminhamento de adultos: Centros Novas Oportunidades. Lisboa, Portugal: ANQ.

Sutherland, P., \& Crowther, J. (Eds.). (2006). Lifelong learning - Concepts and contexts. London, England: Routledge.

\section{Isabel P. Gomes}

University of Porto, Portugal

\section{Alcides A. Monteiro}

University of Beira Interior, Portugal 


\title{
10. DEVELOPING MINORITY COMMUNITIES AGAINST THE BACKGROUND OF THE NECESSARY DREAM OF RETURNING TO THE HOMELAND
}

\author{
MOTHER TONGUE AS THE PREREQUISITE TO INTEGRATION
}

The Bilingual and Bicultural Education Program of the Brussels Regional Integration Centre Foyer originated in the 1977 European Commission Directive on the education of children of migrant workers. The first project started in 1981 in one school where they offered bicultural education to a group of seven Italian children. This means that during the first years of their school career these children were mainly being taught in their own mother tongue rather than in Dutch. Today, after 30 years, the program reaches 520 children, dispersed across six schools. In Flanders, the Dutch-speaking northern part of Belgium, and Brussels, this Bicultural Program of the Foyer is by far the largest, most long-lasting as well as the most integrated project that offers an education to children of ethnic minorities in the 'own-language-and-culture'. The model is explicitly integrated, as a large part of the curriculum is taught in the mother tongue, but without affecting the traditional language education. The Foyer's Bicultural Education Model entails that in the nursery-school classes, for six to eight teaching periods per week, daily activities (such as reception, group discussions, projects, etc.) occur in the children's own language, as an ethnic group separate from the others (Foyer, 2002). During these teaching periods explicit attention is given to the cultural origin of the children. Also in the first level of primary school six to eight teaching periods are given in the own-language-and-culture, while in the second level this is only true for four to five teaching periods. In the third level, such classes are reduced to two or three periods. During these classes specific language education is adopted, but also elements that stimulate the reflection on the own cultural background (customs, communication styles, etc.), and that enrich this background (literature, music, etc.). The 'ownlanguage-and-culture' classes are taught by native-speaking teachers, who are added to the autochthonous teacher responsible for the traditional curriculum. In the Foyer Model the native-speaking teacher plays a pivotal role as he or she integrates the home climate into the school environment and as such increases the intercultural climate in the school. 
In their daily work the teachers and the school are guided by the pedagogical team of the Brussels' Regional Integration Centre Foyer. The latter is responsible for the practical organisation of the lessons and for the consultations in the school and the school environment. The objectives of the project are threefold: the creation of an intercultural perspective within the school, the improvement of study results of immigrant children and the education of the immigrant communities by involving them in Flemish and Brussels' cultural life (Smeekens, 1990). The Foyer model seeks to bring the two communities, the allochthonous and the autochthonous, closer together. The goal of the model is to eliminate the tension between communities by working directly within children's schools. The school is in the best position to stimulate a reciprocal involvement, because education is seen as an institutional way of transferring values and culture (Smeekens, 1990; Marchi, 1990).

The school results of the children are directly proportional to the satisfaction of the parents with the school and the trust they have in the school, as well as in its teachers and counsellors. Consequently the school results of the children within the Foyer Model are better than the average results that have been measured in Flanders and Brussels. One in seven Flemish youngsters drop out of school without a diploma, in Brussels the number climbs to one in four (Corijn \& Vloeberghs, 2009). Seventy percent of the migrant children from Brussels who are being educated within the Foyer Model, that is in their own-language-and-culture, come from deprived milieus. Nonetheless 91,3 percent obtain a valuable diploma of secondary education (Foyer, 2010). Yet the chances of dropping out without achieving formal qualification are much higher for youngsters with a migration background: $30 \%$ of the boys, compared to $13 \%$ in the autochthonous group, and $25 \%$ of the girls, compared to $7 \%$, respectively (Duquet et al., 2006). The roots of educational improvement lie in research on school effectiveness. When schools work in partnership with parents and the community even in disadvantaged areas, schools can improve and their pupils can succeed (Power, 2000).

Education in Brussels in the own-language-and-culture is a complex matter. Brussels' population includes a high concentration of foreigners. In 2007, 27,5\% of the total population was of foreign origin (FOD, 2009). However, since in the last few decades a large percentage of immigrants have been naturalized, in reality half of Brussels' population has foreign roots. Moreover, in the next fifty years, the population of Brussels will increase by $38 \%$ due to the ongoing influx of immigrants and high fertility rates within immigrant communities (Federaal Planbureau België, 2008). The majority of these migrants live in deprivation, which in many cases, is an intergenerational deprivation with an unemployment rate of 25 to $37 \%$ (BISA, 2011). They mainly live in the central districts of Brussels, in older, traditionally working class neighbourhoods. In these areas, Moroccans and Turks constitute more than $50 \%$ of the local population. Concurrently kindergarten and primary school populations in those areas consist of 80 to $90 \%$ of children of foreign origin.

Brussels is a complex city. It is a multilingual city, as well as the capital of two linguistic communities: Dutch speaking Flanders in the north and French 
speaking Wallonia in the south. The linguistic laws permit that only the two official languages, French and Dutch, are to be used in education. In Brussels French is the dominant language, by the native born residents as well as for foreigners who use a dialect originating from their home country, but that is moulded by French influences (Leman, 1990). Nevertheless during the last two decades Dutch has become increasingly important for socio-economic reasons (Reid \& Reich, 1992; Power, 2000). Migrants also know that the demand for people who have knowledge of both languages has increased substantially. Moreover, the foreigners have become increasingly aware that knowledge of both national languages is crucial in order to overcome the marginality of migration (Smeekens, 1990; Leman, 1990; Manço \& Crutzen, 1999).

The Foyer Model focuses on the Dutch educational system in Brussels. In general, classical education of native-born pupils is conducted in the mother tongue, and later on in the curriculum, foreign languages are taught. However in Brussels, Dutch is the mother tongue of only a very small group of people. As such, for the majority, education in Dutch is mostly education in a foreign language. Most migrant children speak a variety of Italian, Spanish, Turkish or Moroccan Arabic dialect, which they then link to French as the language of the street. For those who opt for the programme of education in the-own-language-and-culture, they concurrently choose the Dutch education system and as a result the general language used throughout the school day is a foreign language.

Education in the own-language-and-culture is not as obvious in practice as it is in theory. Until the present time, many people from within the educational system and from the associated socio-political context are convinced that migrant children perform poorly in school, mainly because their mother tongue or their home language hinders them from assimilation to the school language (Padmos \& Van den Berge, 2009). In that belief, it is assumed that children from ethnic minorities are confronted with educational disadvantages since they have been holding on exclusively to their mother tongue for too long, rather than learning the new language of the outside environment (Manço \& Crutzen, 1999). Many people are convinced that the parents of these children bear responsibility for the situation. In addition, parents are seen to be in need of encouragement to learn the language of the host country and, in turn, to speak this new language at home with their children. These people completely reject the idea of education in the-own-language-and-culture in favour of additional classes in Dutch. According to Macpherson (1999) the Belgian researcher Orhan Agirdag calls the pressure on linguistic minority students to abandon their mother tongues and the lack of bilingual education a form of institutional racism. It is "the collective failure of an organisation to provide an appropriate and professional service to people because of their colour, culture, or ethnic origin" (Agirdag, 2010, p. 317).

It is clear that the importance lies in proposing those actions that stimulate integration to the greatest extent. According to Loredana Marchi (1990), a real integration process can only occur if it involves the school. Integration means 
that the concerned groups are actively and appropriately included in the dominant group's goals and activities. The immigrant parents of the Foyer Model accept that the schooling process is a process of better integration.

Language is the bearer of culture. If, from an intercultural perspective, respect is shown for a culture and for cultural diversity in the educational system, the language of the ethnic minorities needs to be assigned a valuable role (Power, 2000). The Foyer Model assumes that support for a subjective cultural identity is by no means detrimental to the social adaptation of the subjects concerned, or to their loyalty towards the host country and its inhabitants. On the contrary, the ability to make ethnic reference to their own 'roots' will be more tranquil and more realistic, at least when it does not hinder the normal integration channels within the autochthonous society. Non-recognition of this subjective identity increases the possibilities of the concerned subjects creating irrational social meanings later, such as of the type which is disintegrative to a society (Reid \& Reich, 1992; Marchi \& De Smedt, 1999; Cummins, 1979; Cummins, 2001).

\section{BICULTURAL EDUCATION AND THE CREATION OF A CULTURAL IDENTITY}

The Foyer Model assumes that language is the symbolic form that embodies culture (Byram, 1990; Bourdieu, 1991, 2000). Ethnic minorities in our society who present themselves as such will mainly distinguish themselves from the dominant group through their usage of language. Leman points to the fact that a government that aims for maximal participation of migrants in public and social life should not eliminate the desire of the minority to distinguish themselves just yet (Cummins, 1979; Leman, 1999). As long as education in the own-language-and-culture does not significantly interfere with the normal course of the curriculum in the school, there is no pedagogic or social reason to eliminate the mother tongue from the educational system. On the contrary, within the Foyer Model bilingual education has proven to be solid ground for bicultural realities in daily life. It offers a structural recognition of 'the otherness' of children of minority groups. On the one hand it acts as proof of equal rights (Leman, 1999), and offers content in a structural way to intercultural education for autochthonous children. Children gradually learn to deal with different lifestyles, other languages and new experiences.

One of the first findings of the Canadian researcher Marcel Danesi in his research on the role of the mother tongue in the schooling process of the Foyer Model in Brussels was that the migrant children involved in the programme enjoyed going to school. The children formed close ties with everyone present at the school and 'they have found their overall school experience to have been an extremely positive one' (Danesi, 1990, p. 72). They liked their school and their teachers and enjoyed coming to school, both to learn and to play. This conclusion is remarkable, especially when we realise that these migrant children to a large extent live in the sink estates in the metropolis. 
Mother tongue literacy constitutes a crucial factor in giving the children the necessary autonomous cognitive status needed for the efficient acquisition of knowledge (Cummins, 1979). Danesi in his research started from the hypothesis that the level of proficiency in the mother tongue was proportionally determinant for the acquisition of a global language proficiency and ultimately, of academic achievement. Children automatically transfer their literacy and cultural skills to the development of proficiency in other languages and the whole school curriculum. The mother tongue is established as a basic fact, although children are able to produce the same thought in several linguistic codes. The linguistic mobility is made possible by a basic accessible code that suits the situation and the speaker (Marchi, 1990; Danesi, 1990). However, it is the pupil who holds the key and who will be aware of his or her abilities. Therefore the passage through the mother tongue is possibly the most natural one (Marchi, 1990).

The significance for migrant children of the usage of the mother tongue, but foremost for their parents, lies in the culture to which they identify. This does not necessarily mean that the mother tongue from the Foyer Model coincides with the language spoken at home. Many second generation migrants in Brussels speak French at home and in intimate environments. They are nonetheless Italian, Spanish, Turkish or Moroccan, which means that there exists an adherence to Italy, Spain, Turkey or Morocco. It is this connection that constitutes their identity, of which language is the symbolic signifier. When children do not know this language because they grow up in an exclusively French speaking environment, then this means they no longer possess the same identity as their parents. Michael Byram (1990) investigated the effectiveness of bicultural education in the Brussels' Foyer Model. Through his interviews he found that Italian parents take on an Italian identity, as long as they are in contact with other Italians with whom they speak Italian. The physical experience of commonality, of which the language is the ultimate symbol, is essential. This is Bourdieu's notion of 'habitus' as the system of bodily dispositions, where people incorporate the same culture as members of the group. The community needs a kind of physical mechanism through which the principles of social organization are embodied such that humans are capable of spontaneously generating an infinite array of appropriate actions (Bourdieu \& Wacquant, 1992). For Byram, there exists the peculiar case of well-educated migrant parents, who possess a thorough knowledge of the language and culture of the homeland, which they also want to pass on to their children. Strangely enough though, they do not speak or speak at only a basic level the language of the host country, despite their intellectual capacity. For Byram, it is exactly this 'unwillingness' that indicates the strength of their affiliation with the homeland and their identity being nestled in that bond. Obviously not all parents are connected to their home language and culture to the same extent, but all parents want their children to have a basic knowledge of their mother tongue. In first instance they value this knowledge because it is useful within the family circle in the homeland. This is the most obvious case for the maintenance of parents' mother tongue in the next generation. However, there is another underlying and more important motive 
for parents to stress the knowledge of the mother tongue and its cultural background vis-à-vis their children: as support and assistance in understanding their own selves and their identity (Byram, 1990). Through the speaking of the language children and parents, whom they identify with, feel connected. Language provides the ability for children to subscribe to the ethnic category (Leman, 1987).

But the contours of this category are never fixed. Instead, they continuously evolve through time. Barth points to the fact that ethnicity is not determined by specific and constant characteristics. Conversely ethnic identity is created from within the context of other identities (Barth, 2000). Ethnic groups do not exclusively create images of themselves from within. In this respect Barth emphasizes reciprocity: a person is a member of a group as a consequence of self-ascription in relation to the other members of the group, but it is simultaneously reinforced by other-ascription, by being categorised by others as a member of a group (Barth, 1969). Identity to a subject is the experience of an identity by which conflicts between one and the other are the pre-eminent constitutive element (Verkuyten, 1999). It is in the exchange and in the confrontation with its limits that identities become real. Language, especially the mother tongue, marks the boundaries between one and another identity. Whether someone knows the language symbolises his or her connection with the group. Therefore when the institutionalised frame of the school partially takes over the responsibility to keep the mother tongue alive with the children, parents can feel deeply supported in the recognition of their identity (Byram, 1990). Language is the strength and the school is the source of this strength, a prospective proficiency for the children to inscribe themselves in the ethnic category and for the parents to re-recognize themselves in this category.

By speaking a language, the reality to which that language refers becomes affirmed. At the same time reality is being exchanged, reformed and shared with others by means of that same language. Language constitutes the community in reality, just as reality makes up the community in the language. In the Foyer Model children are encouraged to use their native speech in the elementary exchange process with their native-speaking teachers. Precisely in the 'language game' of the children, parents project their expectations as part of a past that is threatened with being lost. In this respect, language is not merely an instrument, as it is in the language that the exchange of the past, present and future takes place (Byram, 1990). Language is the bearer of the culture; it connects people in a common life experience. Therefore the mother tongue is not that which coincides with the official language, as viewed in the Foyer Model. Many parents who officially belong to the same language group mostly speak divergent dialects. They feel nonetheless connected as an ethnic community in the official language or national language, which they no longer or were never able to speak (Marchi, 1990; Byram, 1990).

It is clear that parents' choice for bicultural education is not merely motivated by increasing their children's language knowledge. It specifically offers them support and help in the understanding of the self and their loss of identity (Byram, 1990). Parents are extremely aware of the latter in confrontation with their children growing 
up in another country than the homeland. This alienation occurs from the various influences the children undergo in school and broader society. 'The change in ethnic identity is part of a complex change of educational traditions, states Byram. As children gain awareness of other modes of living, they gain a sense of freedom, and for this reason it is no longer feasible to raise them in the manner in which their parents themselves experienced their homeland. Moreover, the emotional solidarity parents possess vis-à-vis that land is the polar opposite of that of their children, as was witnessed by Byram in an interview with Italian parents: “...à la fin des vacances, surtout la petite [fille] elle demande aussi: quand est-ce qu'on retourne en Belgique?... pour eux aussi, la nostalgie du pays de leur naissance règne,...c'est l'envers..." (Byram, 1990, p. 85).

Those children - despite the connection to their parents - already have another identity derived from the very different living conditions in which they are growing up. To the parents this implies a considerable threat. They feel as if they are losing their roots under the domination of the changed living conditions, and are already considered as potential 'adults of silence' (Marchi, 1990, p. 61). Migrants who do not repudiate their heritage, but on the contrary find a way to pass it on to their children, will safeguard themselves against that zone of silence. Therefore it is of the utmost importance that schools, through the possibility of bicultural education, recognise the authentic identity of the parents. As an outcome of this recognition parents in turn are capable of lending the necessary support to the school. Apparently that support is determined by the firmness of parents' own identity and that of their home environment. The school recognises the home culture so that the parents will recognise the school culture.

Children incorporate their parents' longings in the ambivalent relation between the country of residence and the country of origin, whereby for the children the former has become 'home'. The country of their parents is the place where they spend most of their summer holidays. Those visits support the children in the connection with their relatives and the children's affective perception of identity. This has an affective influence on their awareness of the importance of the language. They develop a desire for the language, which therefore is no longer merely functional.

Within the Foyer Model it is the teachers who launch the process of exchange. In his Danish study, Byram has proven that teachers from the same linguistic and cultural origin strongly promote the ethnic identity of their pupils (Byram, 1986). From this perspective, learning the language is only a superficial aim. The mutual involvement of teachers and pupils in the language and culture of the home land creates a certain school culture, a 'school ethos' that shapes the cultural and ethnic identity of the pupils (Byram, 1986, pp. 184-188).

The school is the 'carrier' of that cultural and ethnic identity, mediated by native speakers, who concurrently introduce foreign cultural traditions and customs into the Belgian school system. They connect the culture of the school to that of the home, as from within the school they connect the influences of the host country to those of the migrant parents. Ethnic rearing principles are being adapted to the 
Belgian procedures, just as well as the ethnic living habits are being introduced into the curriculum of the school. It appears that only native teachers are able to accomplish this task. Autochthonous teachers struggle considerably more with foreign living habits. According to Hilde De Smedt, within the Foyer Model all the existing difficulties between the school and the home environment can be reduced to conflicts between parents and autochthonous teachers, where the latter have too little touch with the daily living conditions of the concerned migrant families in the metropolis. Autochthonous teachers live in areas where daily life has little in common with that of the home environment of the migrants (De Smedt, 2010).

Loredana Marchi emphasizes the enormous impact school life has on parents. Parents do believe that schooling contributes to a better integration, for example, that knowledge of languages can be important to once find a suitable job. However, as the language and culture of the school are extraneous to the culture of the mother tongue, parents are concerned and insecure about what happens to their child in the school. This is even more the case when the parents involved are themselves poorly educated. According to Marchi, what happens through the children with the parents in this instance is 'a second immigration': "They try to achieve a more profound integration through their children" (Marchi, 1990, p. 62). Parents expect their children to realise what they themselves have not been able to do. But these expectations towards their children are nevertheless ambivalent. Parents also have doubts about their child's ability to fulfil those expectations. This is even more apparent for migrant parents who are confronted with an unstable social position. At the same time the pressure on them is immense, precisely because of their migrant status. Coming from elsewhere, leaving everything behind to settle down in a new country, is a project that of necessity must be successful. Migrants are always determined to succeed (Byram, 1990). By no means can they allow themselves to go back to their home country.

\section{NO RETURN? IT IS A NECESSARY DREAM}

Two reasons persist as to why parents want their children to participate in the bicultural education model of the Foyer. Firstly, an increasing number of migrants have already acknowledged the importance of the Dutch language in the context of Brussels. If their children, besides their mother tongue, also know French as well as Dutch, then their chance of finding a job on the regular job market increases considerably. Secondly, in the bicultural school children primarily learn their mother tongue, the language that makes them a part of the same ethnic family. The advantage of this is that children can truly connect to their grandparents, uncles, aunts and cousins during their summer holidays.

The latter seems utterly important since it leaves the future completely open to a plethora of possibilities. Within migrant families there are frequent conversations about the possibility for parents and their children to make an eventual return to the homeland. Since the Foyer Model has had the explicit aim of providing pupils with 
an adequate linguistic and cultural experience for them to return to the country of origin, for parents there is instead more discussion on whether they 'would' return. In other words, returning one day is something always talked about, but it is doubtful if it will ever happen. For parents the dream of 'return' supports their own desire. It is a dream that will not be realised because most parents know that their children will not return. But the Foyer Model aims to provide children with the tools of language and culture, which would give them the opportunity to return, and this is seen as an advantage by parents.

Nearly all migrants who came to Belgium did so seeking job opportunities. They left their parents, family, friends and their native region behind and broke their ties to all of these connections. If parents, at the end of their career, decide to return to the homeland and thus leave their children behind, then they would be reversely repeating the same emigration of the past, in that they would displace themselves for the second time. However, migrants never acquiesce in this 'impossible' conclusion. From his interviews with first generation migrant parents, Byram concludes that they continually live on a boundary, they belong nowhere. The pressure of the past and the attraction of the place connected to that past, never ends: ethnic identity is past-oriented and interdependent with the future of the next generation (Byram, 1990). The children on the other hand do not share the same nostalgia; they do not have these memories. This 'tension', between the urge to go back to the homeland and the resistance against it because of the children, becomes bearable by reserving the possibility to go back, yet without acting it out. The place and the country seem subsidiary to these basic family relations: migrants are strangers in the host country, but equally so in the country of origin where they are addressed by their relatives as migrants. Their identity is defined by two opposite places, there home is nowhere (Byram, 2003).

The Foyer Model maintains a fiction that appears to be constructive for so many migrants who live in this paradoxical situation. Parents seem to hold mutually conflicting views: that their children will not return to their country of origin and that they should learn their mother tongue in order to be able to return. The Foyer Model is helping to maintain a necessary fiction: parents hold mutually contradictory views as a means of coping with difficulties in their lives.

Dreams and fictions are part of people's daily lives, though it is particular dreams that mark groups of people or generations within those groups. Moreover it is these dreams and fictions that make out the core of what we call identity. It is in this core that we can observe the difference between one group and another, between minorities and the autochthonous community, between minorities that have been part of the autochthonous community for decades and the newcomers (Bredella, 2003; Sen Gupta, 2003). In his fascinating work on the Foyer Model in Brussels, Byram finds out that 'the dream of return' is linked to the supposed 'objective' elements of ethnic identity, such as the country in which one resides or, where one's parents are still living, or where one was born. Differences arise from these objective elements. As such 'the dream of return' does not bear the same weight for children in the 
bicultural classes as it does for the parents, though they are aware of its importance in the emotional experiences of their parents. These children learn the mother tongue to find recognition and appreciation during their holiday visits. According to Byram, though, this is also a dream, the dream of the holiday in the homeland of their parents (Byram, 1990). It is this dream for adults and their children, which the Foyer Model helps to maintain. Bicultural education for their children is a paradoxical construction that helps parents to participate in a community of dubious membership.

\section{REFERENCES}

Agirdag, O. (2010, May). Exploring bilingualism in a monolingual school system: Insights from Turkish and native students from Belgian schools. British Journal of Sociology of Education, 31(3), 307-321.

Alfred, G., Byram, M., \& Fleming, M. (Eds.). (2003). Intercultural experience and education. Clevedon, England: Multilingual Matters.

Barth, F. (1969). Ethnic groups and boundaries: The organization of cultural difference. Boston, MA: Little, Brown and Company.

Barth, F. (Ed.). (2000). 'Introduction', Ethnic groups and boundaries. London, England: Allen and Unwin. BISA. (2011). Brussels Institute for Statistics.

Bourdieu, P. (1991). Language and symbolic power. Cambridge, MA: Harvard University Press.

Bourdieu, P., \& Passeron, J. (2000). Reproduction in education, society and culture. London, England: Sage Publications.

Bourdieu, P., \& Wacquant, L. (1992). An invitation to reflexive sociology. Chicago, IL: University of Chicago Press.

Bredella, L. (2003). For a flexible model of intercultural understanding. In G. Alfred, M. Byram, \& M. Fleming (Eds.), Intercultural experience and education. Clevedon, England: Multilingual Matters.

Byram, M. (1986). Minority education and ethnic survival. Clevedon, England: Multilingual Matters.

Byram, M. (1990). Return to the home country: The 'Necessary dream' in ethnic identity. In M. Byram \& J. Leman (Eds.), Bicultural and trilingual education. Clevedon, England: Multilingual Matters.

Byram, M. (2003). On being 'bicultural'and 'intercultural'. In G. Alfred, M. Byram, \& M. Fleming (Eds.), Intercultural experience and education. Clevedon, England: Multilingual Matters.

Byram, M., \& Leman, J. (Eds.). (1990). Bicultural and trilingual education. Clevedon, England, Multilingual Matters.

Corijn, E., \& Vloeberghs, E. (2009). Brussel! urban notebooks, stadsschriften. Brussels, Belgium: Vubpress.

Cummins, J. (1979). Linguistic interdependence and the educational development of bilingual children. Review of Educational Research, 49(2), 222-251.

Cummins, J. (2001). Bilingual children's mother tongue: Why is it important for education? Sprogforum $\mathrm{Nr}, 7(19), 15-20$.

Danesi, M. (1990). Mother tongue literacy and the 'Shaping' of knowledge: The experience of the Italian children. In M. Byram \& J. Leman (Eds.), Bicultural and trilingual education. Clevedon, England: Multilingual Matters.

De Smedt, H. (2010). Oral interview. Brussels, Belgium: Foyer.

Duquet, N., Glorieux, I., Laurijssen, I., \& van Dorsselaer, Y. (2006). Wit krijg schrijft beter: Schoolloopbanen van allochtone jongeren in beeld [White chalk writes better: The image of the school career of allochthonous youngsters]. Antwerp, Belgium: Garant.

Federal Plan Office Belgium. (2008). Brussels.

FOD. (2009). Fod federale overheids diensten [Federal public authorities], Brussels.

Foyer. (2002). Evaluatierapport [Evaluation report], Brussels.

Foyer. (2010). Evaluatierapport [Evaluation report], Brussels.

Leman, J. (1987). From challenging culture to challenged culture. Leuven, Belgium: University Press. 
Leman, J. (1990). Multilingualism as norm, monolingualism as exception: The Foyer model in Brussels. In M. Byram \& J. Leman (Eds.), Bicultural and trilingual education. Clevedon, England: Multilingual Matters.

Leman, J. (Red.). (1999). Moedertaalonderwijs bij allochtonen: Geintegreerd onderwijs in de eigen taal en cultuur [Mother tongue education for allochthones: Integrated education in their own language and culture]. Leuven, Belgium: Acco.

Macpherson, W. (1999). The Stephen Lawrence inquiry. London, England: HM Stationery Office.

Manco, A. A., \& Crutzen, D. (1999). De Moedertaal En De Taal Waarin Onderwezen Wordt: Een Sociolinguïstisch Probleem, Bestudeerd Aan De Hand Van De Situatie Van De Turken En Marokkanen in België [Mother tongue and education language: A sociolinguistic problem researched in relation to the situation of turks and moroccans in Belgium]. In J. Leman (Red.), Moedertaalonderwijs Bij Allochtonen: Geïntegreerd Onderwijs In De Eigen Taal En Cultuur [Mother tongue education for allochthones: Integrated education in their own language and culture]. Leuven, Belgium: Acco.

Marchi, L. (1990). Language in immigration: Creativity and linguistic mobility. In M. Byram \& J. Leman (Eds.), Bicultural and trilingual education. Clevedon, England: Multilingual Matters.

Marchi, L., \& de Smedt, H. (1999). Inleiding tot de biculturele onderwijsprojecten, Regionaal Integratiecentrum Foyer [Introduction to the bicultural education projects, regional integration centre Foyer]. Brussels. (Unpublished)

Padmos, T., \& van Den Berge., W. (2009). Het verschil maken: Gelijke kansen in het beroeps-en technisch secundair onderwijs in Vlaanderen [Making the difference: Equal challenges in vocational and technical training in flanders]. Gent, Belgium: Steunpunt Gelijke Onderwijskansen [Regional centre for equal education challenges].

Power, C. N. (2000). Global trends in education. International Education Journal, 1(3), 152-163.

Reid, E., \& Reich, H. (1992). Breaking the boundaries: Migrant workers' children in the EC. Clevedon, England: Multilingual Matters.

Sen Gupta, A. (2003). Changing the focus: A discussion of the dynamics of the intercultural experience. In G. Alfred, M. Byram, \& M. Fleming (Eds.), Intercultural experience and education. Clevedon, England: Multilingual Matters.

Smeekens, L. (1990). Structural change: From monocultural to bicultural schools. In M. Byram \& J. Leman (Eds.), Bicultural and trilingual education. Clevedon, England: Multilingual Matters.

Verkuyten, M. (1999). Etnische identiteit: Theoretische en empirische benaderingen [Ethnic identity: Theoretical and empirical approaches]. Amsterdam, The Netherlands: Het Spinhuis.

\section{Paul de Roo}

\section{Department of Political Sciences}

Ghent University, Belgium 



\section{ÖZLEM ÜNLÜHISARCIKLI}

\section{ADULT LITERACY PARTICIPANTS IN TURKEY}

\section{INTRODUCTION}

The first Turkish population census, in 1927, revealed that only about $9 \%$ of the whole population (out of a population of $13,648,270$, only $1,111,496$ ) knew how to read and write in the Arabic alphabet. With the language reform in 1928 the Arabic alphabet, which was in use for about a thousand years, was abolished and replaced by the Turkish alphabet developed with Latin letters (29 letters that consisted of 8 vowels and 21 consonants). Following the alphabet reform Nation Schools were established to teach how to read and write to the whole nation. In the initial literacy campaign in 1928 alone 579 thousand people attended these schools (Öz, 2002). The objective was not only to improve the level of literacy with the new alphabet but also to develop a sense of citizenship at the same time. Taşçı Günlü (2008) argues that those early efforts were directed towards creating cultural unity for the creation of the nation state in Turkey.

Since the initial campaign in 1928, there have been several other literacy campaigns and programs in Turkey along with the regular adult literacy education programs offered to the public. The Turkish Armed Forces provided literacy education in Private Literacy Schools from 1959 to 1975 (Öz, 2002); a literacy campaign for women was undertaken in 1962; two other literacy campaigns took place between 1971-1974 and 1981-1983 (Kirazoğlu, 2003); in 1992 a new literacy campaign was conducted; the Literacy Campaign for Young Girls and Women was initiated in 1997, 2001 saw the start of a new trend in literacy campaigns: the wife of the President of the country then initiated a literacy campaign with the slogan 'Support for National Education' in 2001 (Bilir, 2005) and about 1.5 million people participated until the campaign ended in 2007 (GDLLL, undated). In early 2008 another campaign was initiated with the slogan 'Turkey is Literate' by the wife of the President; and finally in September 2008 the wife of the Prime Minister launched the last literacy campaign in Turkey with the slogan 'Mother-Daughter Together in School.'

Over the years literacy rates improved but remained a problem in Turkey. In 2000, about $13.5 \%$, and in 2008 , about $10 \%$ of the population was illiterate. In 2012, the overall illiteracy rate was about 5.1\% (approximately 3 million people over 15 years of age were illiterate); moreover, there is a gender gap (the overall illiteracy rate for males was $1.7 \%$, whereas it was $8.4 \%$ for females) (TURKSTAT, 2013). 


\section{LEGAL FRAMEWORK AND MAIN PROVIDERS OF ADULT LITERACY}

Literacy Training for Citizens who are out of the Compulsory Primary Education Age Law No. 2841, enacted in 1983, regulates adult literacy education programs for the population over compulsory school age. The responsibility for program development and coordination is with the Department of Basic Learning Needs under the Ministry of National Education (MoNE), General Directorate of Lifelong Learning $^{1}$ (GDLLL).

Public Education Centres (PEC), which were established in 1955, are the main providers of adult education, including adult literacy courses, for free to the public and operate under the MoNE, GDLLL.

PECs function in all 81 provinces of Turkey. In 2010-2011, 969 such centres offered vocational and technical education, general education, and adult literacy courses. About 4.5 million people participated in these adult education courses in various programs. About 940 thousand of these were adult literacy course participants (223 thousand male, and 717 thousand female) (TURKSTAT, 2012).

There are two types of literacy courses: Level I and Level II. The Level I literacy course, which is the equivalent of grades 1 and 2 of primary school, may also be provided in cooperation with other state institutions such as the Turkish Armed Forces and Ministry of Justice; and NGOs such as the Mother-Child Education Foundation, the Rotary Club, and the Association for Supporting Contemporary Life. Among these institutions, only the Mother-Child Education Foundation and Rotary Club have their own literacy education curricula approved by the MoNE. These are the Functional Adult Literacy Program (FALP), and the Simplified Literacy Education Program (SLEP) respectively. All institutions that run Level I equivalent literacy courses have to cooperate with GDLLL and PECs to offer these courses. The time duration of Level I courses are 120 hours and provide basic levels of literacy. The Level II literacy course, which is the equivalent of grades 3 and $4^{2}$ of primary school, is offered only by PECs. The time duration of Level II courses are 180 hours.

Although the whole illiterate population over compulsory school age is the target for adult literacy education, priority has been given to the economically active population, to females to ensure gender equity, and to poor people in both urban and rural regions (Nohl \& Sayılan, 2004; Ulusavaş, 1994).

The number of research studies on adult literacy, especially from the perspectives of the participants, is limited in Turkey. A research study utilizing both quantitative and qualitative data investigated the impact of the FALP on the personal growth and development of the participants and pointed to the effectiveness of the program, though the findings indicated that the length of the program was too short (Durgunoğlu, 2000).

In a study exploring the effect of Level I literacy courses on women's lives Yazlık (2008) conducted semi-structured interviews with seven female participants. In her study Yazlık reported that these women suffered under patriarchal power structures and economic constraints. Participation in the Level I literacy course enabled these 
women to travel by public bus and do things they had relied on others for earlier; participation increased their self-confidence and sense of independence.

In another study Yildiz (2008) studied the popular ideas, attitudes, and value patterns that negatively affect participation in literacy programs in a slum neighbourhood with a high illiteracy rate in Ankara. The findings revealed that, in the neighbourhood, psychological factors such as the fear of not being able to learn, the dominance of oral culture and the undervaluing of literacy, aging, and gender had a decisive impact on participation in literacy courses. Yildiz discussed how female illiteracy enabled the male to exert control over the female to maintain traditional lifestyles.

Ünlühisarcıklı (2009) in her study focused on the views of teachers in terms of how the regulations for implementation and assessment on adult literacy apply to the everyday practices of adult literacy education in Turkey.

\section{METHOD AND PARTICIPANTS}

This is a case study which analyses the learning experiences of adult literacy education participants and how participation in literacy education affected their daily life. The study took place in one of the 33 PECs in Istanbul in the initial year of the 'Mother-Daughter Together in School' literacy campaign, in 2008. The PEC where the data was collected is a medium-sized centre, situated in a middle socioeconomic stratum (SES) neighbourhood in Istanbul and offers Level I and Level II adult literacy courses to the public on a regular basis besides several other courses and activities.

When I visited the centre to find out about the schedule of the courses and which classes would be suitable to observe and for conducting the interviews, I consulted the full-time literacy teacher who also had administrative duties in the centre. After checking suitable times when I would visit the centre for the study, he suggested a primary school teacher who offers adult literacy courses in the PEC on a part-time basis. It is a common practice of PECs to offer adult literacy courses in cooperation with primary school teachers who work at these centres on a part-time basis. Later, he introduced me to her and we had the opportunity to agree on a schedule for my visits to the literacy classes. She was a positive support during the data collection procedure.

The sample consisted of the participants in one of the two different adult literacy education classes taught by the same teacher, and who volunteered to be interviewed. In both of the classes the class sizes are about 20 people. Although one of the classes is Level I and the other is Level II the teacher explained that the Level II course is in fact a 'fake-Level II' and may be considered as being Level I. She explained further that the fake-Level II participants are the ones who have attended a Level I class before but who have not mastered the Level I to pass on to a Level II class. But since they have attended Level I before, the PEC administrators did not want them to register on a Level I course again, so instead they offered another class. However, the 
teacher indicated that the participants in the fake-Level II class do not have a chance of passing the exam at the end of the program to receive a Level II certificate. This is because the topics covered in the particular class are far below what Level II should be. In fact, this practice of "introducing some flexibility into the system to adapt the individual programs to the learning needs of participants" (Ünlühisarcıklı, 2009, p. 55) is not unusual and is considered as a means to circumvent the regulations. The voluntary interviewees are from this so called fake-Level II class.

Altogether I interviewed eight participants on a voluntary basis. The interviews were semi-structured and carried out within the time duration of the classes because the participants did not have extra time to spare before or after the class time. When the class time was over they used to hurry back to their homes. Therefore the interviewees, with the permission of the course teacher, did not attend one class session, so that we could have the interviews. The interviews took place at the refectory of the PEC and on average took about half an hour each. I also attended the classes several times to observe the class.

The youngest of the interviewees was 31-years-old and the oldest was 62 . They were all married with children. Except for Hasan, who is an Afghan and migrated to Turkey years ago, all the participants in both of the classes were female and migrated to Istanbul from different parts of Turkey. All of the interviewees migrated to Istanbul generally in their teens. Marrying someone in Istanbul and the husband's business are the main reasons for the women to migrate to Istanbul. The partners also had lower education levels.

Table 1. Interviewees of the study

\begin{tabular}{lllll}
\hline Pseudo-name & Age & Gender & $\begin{array}{l}\text { Age of } \\
\text { migration }\end{array}$ & $\begin{array}{l}\text { Partner's level of } \\
\text { education }\end{array}$ \\
\hline Necla & 54 & $\mathrm{~F}$ & 13 & 5 year primary \\
Merve & 42 & $\mathrm{~F}$ & 11 & Secondary school \\
Kevser & 56 & $\mathrm{~F}$ & 13 & Only literate \\
Hatice & 60 & $\mathrm{~F}$ & 20 & 5 year primary \\
Fatma & 62 & $\mathrm{~F}$ & 15 & 5 year primary \\
Meral & 31 & $\mathrm{~F}$ & 20 & 5 year primary \\
Nur & 51 & $\mathrm{~F}$ & 16 & 5 year primary \\
Hasan & 37 & $\mathrm{M}$ & 27 & 5 year primary \\
\hline
\end{tabular}

FINDINGS

Narrative analysis with a thematic approach is used in analysing the data. Thematic analysis is used as a "qualitative method to identify, report, and analyze data for the meanings produced in and by people, situations, and events" (Floersch \& Longhofer, 2010, p. 408). Data are interpreted through thematics (of, relating to, or consisting 
of a theme or themes) developed by the researcher (Riessman, 2008). A theme "captures something important about the data in relation to the research question, and represents some level of patterned response or meaning within the dataset" (Braun \& Clarke, 2006, p. 82). Therefore, I initially coded the data that I gathered from the voluntary interviewees in the fake-Level II adult literacy class and then grouped similar codes together and created themes. Then, within-case and cross-case analysis of the interviews were done according to these themes.

The data revealed that interviewees had some similarities concerning their reasons for not going to school, the decision to learn how to read and write later in their life, and changes in their perceptions of themselves as a result of the learning experience. The quotes provided in the findings are either the ones that represent similar views or atypical views that are important to focus on. To protect the identities of the participants, pseudonyms are used in the reporting.

\section{The Road to Literacy}

Kevser, who had married at 13, pointed out the fact that since she was the elder sister, she took care of her younger sisters and brothers who were all sent to school while she was not, which left her with bitter feelings for the rest of her life. Moreover, she reflected that because she felt ashamed, she could not tell her neighbours about her being illiterate. She still felt remorse whenever she passed by a school:

Whenever I pass a school my heart aches. I did not have the experience, I didn't have the opportunity to put on my school uniform and play with my friends in the school garden, and something is missing in me. I hated my mother, hated her. She ruined me, but I didn't do the same with my daughter. (Kevser)

Hatice is the elder sister in her family and got married at the age of 13; Merve also had similar experiences:

I didn't go to school. My family didn't send me. They said 'girls don't go to school'. My brothers did. My younger sisters also went to school. I am the oldest, they didn't send me. They wanted a hand at home I suppose. I would very much like to go to school. It is a pain in me. I got coldness from my parents, I felt outcast since they allowed my younger siblings to go to school. I will support my daughters to continue their education. (Merve)

Fatma had a similar but yet different experience of not being sent to school and indicated the dimensions of paternalistic exertion of power over women:

I wasn't sent to school, so that I wouldn't write love letters to boys! My elder brothers wanted me to go to school but my father didn't allow it. In the end, my father even got a report which indicated that I am 'blind'. In order not to send me to school. My mum went to school when she was a kid, she wanted me to go but my father didn’t. (Fatma) 


\section{Ö. ÜNLÜHISARCIKLI}

Necla has a similar story as she wasn't sent to school because at that time girls were not supposed to go to school. She was also married underage at 13, with the consent of her father. Giving birth to 5 children and looking after them, she had no time for anything else; she has no work experience either. Now that her husband has passed away and the kids have got married she has all the time for herself. In other words, having been married with children and having raised them to young adults, and not having many family responsibilities, these women had the opportunity to realize their long-lost desires to go to school. Therefore, learning literacy becomes an option only when women are freed of their child caring and other duties. Nur's son registered her on the course because she was bored at home. Similarly,

My children said 'mum, this is nice, of course go'. They are busy with their own business; since I got older they don't care much and have left me on my own. (Fatma)

It seems that these women had the support of their families which they did not have in their childhood. Meral, who was the elder sister of 8 siblings, had gone to school only for a year in her childhood, but had to drop out since her family expected her to work in the fields. Now, having her own family, she has her husband's support:

Bless him my husband registered me on this course... I used to say 'I wish there was a school I would go'. He searched and told me that there was such a school and if I wished he would take me there. And I wanted it. My biggest son is now in 6th grade. (Meral)

The only different motive for attending the adult literacy course is that of the Afghan Hasan. It had been 10 years since Hasan came to Turkey in an escape from war in his country. Meanwhile he had become a Turkish citizen, had married and had a six-monthsold daughter. Although he had been to school for 3 years in Afghanistan, he could not manage to learn how to read and write properly in his own language since there had always been interruptions in schooling and finally his school had been demolished during the fighting. Now, he is working at a restaurant as a dishwasher.

Actually, I am a cook, I can cook. But since I am illiterate the boss did not allow me to become a cook. First I will learn how to read and write, and then I need to get the mastership certificate. I need to get the permission from the Ministry of Labour. I was looking for a course and a friend told me that he had seen the announcement sign of this centre... My wife is very supportive but my work conditions are very heavy, I work from early in the morning till 11 at night. It is difficult for me to arrange my schedule to the course time, they don't give support at the workplace, and it is hard. (Hasan)

In his study Y1ldiz (2008) reported the negative attitude of the neighbourhood and the male family members against the participation of women in adult literacy 
courses. Coming from middle-SES families, the women interviewed in this study all had family support from their children and husbands.

\section{The Initial Experiences}

Generally the interviews revealed that the interviewees did not know earlier that such adult literacy courses existed. Necla and Fatma indicated that they would have come earlier if they had known. Similarly, Merve heard about the course only when it was advertised on the television:

On the television I saw the 'Mother-Daughter Together in School' campaign. I came together with my younger daughter to fill in the forms. I didn't know before that PECs offered such courses. I knew that there was a literacy course at my children's primary school, but I didn't want to go. I didn't want my kids to be offended because their mum did not know how to read. If I had known I would have come earlier... (Merve)

The first day of the course, participants had diverse feelings and were excited for different reasons. Necla indicated that at the very beginning she had the fear of not being able to learn: 'I was afraid of not being able to write, not being able to recognize the letters. You know nothing. You can't even distinguish A from B'. Another shared feeling is the anxiety of not being able to fit in, and being too old to go to school. Nur, who is 51 years old, explained this anxiety felt at the beginning of the course:

In the East we have a different kind of shyness. The first day I was shy because I feared that people might disdain me for coming to school 'at this age!' But then I recognized that there are people older than me, and others younger than me. I felt pleased since there are younger ones who haven't been to school as well. (Nur)

Seeing that others were also like them helped the participants to feel at ease in the classroom. Meral, who always had difficulties in socializing with people without feeling excited, felt anxiety in the initial days of the classes, but when the teacher encouraged her by saying: 'we are not different from each other, I am also like you' she felt more relaxed. She explained her first day's experience at school as a memorable event:

It was crowded. I got very excited. I felt as if I was a child. The director gave a speech. We were like kids. We were as pleased as the children would be on the first day of school. As if we hadn't grown up, never got married. (Meral)

The learning is considered to be a natural process for the women. When asked about their initial learning experiences, they did not mention anything specific; first they learned how to use a pencil, how to draw lines and shapes, then they are introduced to the letters one-by-one and for them the key is practice and repetition 
as many times as it requires. It was difficult for them to explain how the learning process took place in the classroom.

It is hard to explain. Learning the syllables and spelling were very difficult. We wrote the same syllables over and over again. We did repetition all the time. We still do. We learned syllable by syllable. It is difficult for me to remember everything. We learn, but with difficulty. I forget very quickly. Our teacher is very determined. She gives us homework, I read over and over again. (Merve)

The course covers some numeracy skills besides literacy. They learn simple calculation using the four operations, but mainly addition and subtraction. Some women mentioned that they knew a bit of simple calculation even before the course, since they needed it in their daily lives. But Necla mentioned that learning math was also very important for her since she didn't know even simple calculation. Before the course, when she went to the market she used to give some money to the salesperson and she would get back whatever change they returned her. This is her third year in the course, and there are others who have attended a literacy course more than once like her. As for the reason for attending the same course more than once, they generally mentioned the need for more repetition and that when they did not practice they would forget.

Although the women mentioned family support for participating in the course, they complained that family members did not have the wish or patience to help and that family members are tolerant about the women spending time at the course, but they do not like to spare time to help them out with their homework. Although Meral had the full support of her husband to come to this course, still she complained of not being able to get help at home when she needed it:

When I practice at home sometimes I ask my children and husband, but my children say 'we also have our own homework!' and they don't help. Moreover, once my husband told me 'you've been going to school for months, if you won't be able to learn then perhaps you should leave school'. It stimulated me even more, I will learn despite them. I told my teacher and she said 'don't drop out'. (Meral)

\section{Life as a Literate Person}

The participants all mentioned that a sense of confidence developed as a result of becoming literate. Except for Hasan, who had been to school for three years, and Meral, who had been to school only for a year, it was the first time in their life that they had attended an organized learning experience. Being in the classroom was considered a pleasant experience, as Fatma said plainly: "now I love getting up in the morning". In the classroom the participants sit around tables put together in a u-shape design which allowed each student and the teacher to see each other. The size of the class was not big and the chairs around the tables were squeezed side by side 
to fit in the number of participants giving an impression of crowdedness. However, students seemed happy to sit on their chairs around the tables while practicing with the teacher in humming voices. The learning experience alone seemed to have a positive effect on the participants. Moreover, they looked on it as a social experience at the same time:

I like being together with friends, to be in society, I like the crowd. We not only meet at the class but come together from time to time. I was bored sitting at home. That changed. (Nur)

The sense of confidence developed was something that changed their life. While shopping, looking for an address, taking a bus, depending on others to understand things in newspapers are all factors which contributed to the feeling of inferiority before they became literate. Fatma stressed that since children are brought up by their mothers, the education of girls should be taken more seriously, and added that she wanted her sons to marry educated girls. Merve reflected her feeling of rage at being illiterate and the unfairness of that: "you ask yourself why am I lesser than them?" Necla confessed that she did not tell her neighbours that she was attending a literacy course, but a driving license course. Similarly, Nur told that she had no illiterate friend other than herself. In short, they felt that if you are a literate person:

You walk with strength, with confidence. When you are illiterate you are fainthearted, you don't have the guts to ask people, they say 'are you blind'. Now I don't have that timidity. Now I am not afraid of going to places, not hesitant because I am a woman. (Kevser)

\section{CONCLUSION}

The participants in this study all had experience of migration. The reasons for migration were generally marrying someone already living in Istanbul or on the basis of business. There is also the factor of being the elder daughter of the family who had to look after the sisters and brothers or work in the fields. The gender issue, the fact that overall female illiteracy is higher than male illiteracy in Turkey, revealed itself in this study also. The women interviewed attended the adult literacy course in their later years only after their responsibilities in the family lessened. Attending the adult literacy course did not only provide them with literacy skills but also provided an opportunity for social interaction and a reason for getting up in the morning. Prins (2006) points out the importance of the social purposes of literacy programs for relieving people from isolation.

This study providing information on the experiences of participants in adult literacy classes in Turkey may contribute to the knowledge of researchers and policy makers. Additional studies will provide further data on the impact of learning experiences and the social contribution of these practices to the lives of adults. 


\section{Ö. ÜNLÜHISARCIKLI}

\section{NOTES}

1 Until recently the name of this general directorate was General Directorate of Apprenticeship and Nonformal Education. In September 2011 with the restructuring of the Ministry of National Education the name has been changed to General Directorate of Lifelong Learning.

2 Until 2012, Level I literacy courses corresponded to grades 1-3, and Level II literacy courses corresponded to grades 4-5. With the recent Primary Education and Education Law No 6287 issued in March 3, 2012, compulsory education is divided into $4+4+4$ instead of the former $5+3$ years.

\section{REFERENCES}

Bilir, M. (2005). An evaluation of education (the literacy) campaigns in terms of the adult education in Turkey. Ankara University Journal of Faculty of Educational Sciences, 38(2), 103-125.

Braun, V., \& Clarke, V. (2006). Using thematic analysis in psychology. Qualitative Research in Psychology, 3(2), 77-101.

Durgunoğlu, A. Y. (2000). Adult literacy: Issues of personal and community development (Final report). Chicago, IL: Spencer Foundation.

Floersch, J., \& Longhofer, J. L. (2010). Integrating thematic, grounded theory and narrative analysis: A case study of adolescent psychotropic treatment. Qualitative Social Work, 9(3), 407-425.

GDLLL. (n.d.). Okuma-Yazma Çalışmalarının Tarihçesi (online). Retrieved January 18, 2014, from http://okuma-yazma.meb.gov.tr/tarihce.

Kirazoğlu, C. (2003). An evaluation of adult literacy campaigns in Turkey (Unpublished dissertation). Boğaziçi University, İstanbul, Turkey.

Nohl, A. M., \& Sayllan, F. (2004). Teaching adult literacy in Turkey: Technical report to the support to basic education program. Ankara, Turkey: Ministry of national education/European Commission.

Öz, M. (2002). Türkiye Cumhuriyeti'nde okuma-yazma seferberlikleri ve yönetimi. Eskişehir, Turkey: Anadolu University.

Prins, E. (2006). Relieving isolation, avoiding vices: The social purposes of participation in a Salvadoran Literacy program. Adult Education Quarterly, 57(1), 5-25.

Riessman, C. K. (2008). Narrative methods for the human sciences. Thousand Oaks, CA: Sage.

Taşçı Günlü, S. (2008). Adult literacy campaigns and nation building. In A. M. Nohl, A. Akkoyunlu-Wigley, \& S. Wigley (Eds.), Education in Turkey: European studies in education (Vol. 26). Münster, Germany: Waxmann.

TURKSTAT. (2012). National education statistics, non-formal education 2010/'11. Ankara, Turkey: Turkish Statistical Institute.

TURKSTAT. (2013). Statistical indicators, 1923-2012. Ankara, Turkey: Turkish Statistical Institute.

Ulusavaş, M. (1993). The Turkish adult education system, ERIC document (ED364662).

Ünlühisarcıklı, Ö. (2009). Literacy, learners and laws: A Turkish case study of surviving regulation. Literacy and Numeracy Studies, 17(3), 42-56.

Yazlık, Ö. (2008). The effect of people education centers' literacy courses on women's lives (Unpublished Master's Thesis). Boğaziçi University, İstanbul, Turkey.

Yildı, A. (2008). Popular ideas, attitudes, and value patterns affecting participation in adult literacy programs in slum communities of Turkey: The case of Nato Yolu neighbourhood. Adult Basic Education and Literacy Journal, 2(2), 74-83.

\section{Özlem Ünlühisarcıklı \\ Faculty of Education \\ Boğaziçi University, Turkey}




\section{SECTION III}

LEARNING IN SOCIAL MOVEMENTS

AND SOCIAL CHANGE 



\title{
12. THE INVOLVEMENT OF WOMEN IN TRAINING
}

\author{
A Step Towards an Emancipatory Community Development Process
}

\section{INTRODUCTION}

This text is based on research conducted in the small village of Cachopo, located in the mountainous northern Algarve region of southern Portugal, between 1998 and 2002. Some additional field work was carried out between 2002 and 2010. The personal interviews the authors conducted allowed them to explore older data through the lens of new theoretical frameworks. This project produced new insights and new meanings.

The project RADIAL (which later gave birth to the civil society organisation called In Loco) was devoted to tackling problems of development in this inland area of the Algarve. In response to the structurally unequal situation women experienced, this organisation initiated a number of projects targeting women in the region. In 1985, a local development process was initiated, in cooperation with the population, which combined participatory research with a particular focus on local development and popular education (Fragoso, 2009). The goal of our research was to develop a deep understanding of the local development process that occurred in Cachopo between 1985 and 2002. In this chapter, we only analyse data concerning women's training experiences in Cachopo. We utilised case study research as defined by Stake (2000) and non-structured interviews, as well as lengthy, continuous periods of observation as participation.

\section{WOMEN IN TRAINING: THE CASE OF 'LANÇADEIRA' (1986-1994)}

The initial "Lançadeira" group was formed by seven women who desired to learn weaving and hoped, eventually, to create a weaving business. Weaving was a traditional activity in the area. However, the idea was to innovate from local knowledge along both technical and pedagogical lines. Given that it was important to promote a collective spirit among the women, the training programme's initial characteristics were established through negotiations. For example, the group collectively established, in reference to the workshop's needs, the content of some of the practical rules regarding discipline. They also decided to combine theoretical and practical components in the operation of the workshop and to place $30 \%$ of every participant's salary into a common bank account. 
The training sessions were held in a community space in Cachopo. The programme also included several study trips (to wool and cotton factories, for example) to familiarise the participants with the materials they used and excursions to various fairs and exhibitions to allow them to show and/or to sell their products. In this way the women obtained the opportunity to travel in their own country and even to leave Portugal for the first time. In the purely pedagogical realm, the training sessions were difficult for most women, especially with regard to those subjects that were not immediately practical. Some of the women had left school at an early stage in life for reasons common to rural areas in Portugal: economic motives, the management of small rural properties, care for their family's older adults or children and conformity with very traditional gender roles (which did not include education of young girls).

The most important obstacles to the growth and emancipation of these women were located in the community and the family. The simple fact that there was a workshop where a group of women remained for the entire day behind closed doors was motive enough to trigger violent reactions from the community. The women were also accused of abandoning their homes and with leaving the men alone to discharge such daily tasks as bathing the children and cooking. In addition, weaving was considered a 'legitimate' activity only so long as it remained incarcerated within homes and was confined to the family's needs. The tone and intensity of community criticisms intensified when the women started travelling. The community's reactions were just a corollary of the conflicts women faced inside their own families:

Sara: It was very difficult and I believe they [husbands and sons] took too long to understand this was my work. 'Don't go...' Sometimes my husband started:

'ah, silly, you are all the time over there... don't go!' They didn't understand that this was a part of me.

António: When you say they took too long to understand that was your job (...)

Sara: Years! Don't think this was just a year or two...!

When the two-year training period ended, the challenge was to sell enough products to make the micro-enterprise viable. For roughly two additional years, attempts to find a market niche were unsuccessful. The almost invisible amounts of money these women took home at the end of the month made it difficult for their families to accept their activities. The general situation was worsened when four of the women decided to obtain driver's licenses. This was in a village where only two upper-class women had such licenses, not to mention the fact that the nearest driving school was located about $40 \mathrm{~km}$ away. These four women, in the end, did not give up (which the other three did), and around 1993/94 their economic situation stabilised.

The economic situation of the micro-enterprise gradually improved. This change, along with the fact that the workshop was frequently visited and appreciated by outsiders, finally transformed the community's perceptions of the experience and of the women. While this training process was, indeed, a learning opportunity for the women involved, it simultaneously forced onto others a process of social learning: 
"that's because I always say that this job... this that today is my job, was important not only to my education, but also to educate the others in my home" (Laura).

\section{WOMEN IN TRAINING: THE CASE OF 'LANÇADEIRA' (1994-2002)}

This small group of four women (Salome, Maria, Laura and Angel) finally achieved some stability in their micro-enterprise. They earned, due to their continued efforts, dignified employment and economic independence. They are also unanimous in considering the training process as the beginning of a larger process of awareness or, to use Laura's words, "Doors that have opened other doors". They were able to emancipate themselves from the unequal gender roles that their husbands, families and community had imposed on them.

We suffered from the community, suffered in our homes with our husbands because they wouldn't understand the situation, and believed we had nothing to do there [in the training sessions]... and now, wherever I go my husband comes along (...). I managed, I managed to change! And now when I say "on such day I'm going to such and such a place," he says if he can: "I'm going also." (Maria)

These women also understood they could be active members of the community and, accordingly, started to act in public spaces. This first rupture was fundamental: it meant breaking out of their confinement within private/family spaces and viewing themselves as people capable of having a voice in public spaces, a role that traditionally belonged to men. The four became part of a group of citizens who, from 1994 on, has organised an important local fair that provides local producers a place to show and sell their products. This event draws between 2000 to 4000 visitors. The four also created connections with other types of groups that changed their community in a number of ways.

Laura collaborated with a group of other women (who had participated in a different training programme for women) to form a new cultural association. With the support of a considerable number of young adults from the community, they organised a folk dancing group (with approximately 25 members) and a small singing group (with six to eight members). They also organised traditional public festivities and, beginning in 2000, began celebrating the International Day of Women on the 8th of March. Laura was a candidate in the 1997 municipal elections, losing by a margin of only twelve votes. She also ran in the 2001 election and again lost. In these same elections, Sara was elected to local office as a candidate of a different political party. A political division exists in Cachopo (where the population divides its allegiance between two different political parties), and the fact that Sara and Laura became political 'enemies' worsened their relationship within the workshop.

The case of 'Lançadeira', as presented here, can be considered typical with regard both to the role an educational programme can play in emancipating women during a time in which obstacles to such a goal are still rife. 


\section{OBSTACLES WOMEN FACE DURING THE EMANCIPATION PROCESS}

In the Lançadeira project, seven women joined the programme and four went on to create their own business. For women, joining a training programme entails enduring radical, practical changes throughout their daily lives. First, as is often mentioned in writings on women's and adult education, childcare and the feeding of their family are vital problems women must solve in setting their daily and weekly schedules (Nicole-Drancourt, 2009). In Lançadeira, the decision to ask the women to spend 36 hours a week in the workshop probably discouraged more women from joining the programme. Other programmes allow flexible schedules. Such schedules act as support mechanisms that allow women to participate while retaining their domestic role. But a decision to offer this flexibility is open to question and the utility of such a schedule probably depends on local culture. Women remain, for the most part, the only guarantor of an optimal family life.

Training programs imply a re-organisation of women's lives, the nature of which depends on national, regional and local rules and infrastructures (Fletcher, 2005). The partner gains new responsibilities that vary according to the individual. Some partners prevent their wives from attending training sessions for reasons that go beyond those associated with the practical problems of childcare. These rationales are connected with traditional representations of gender roles, which stipulate that wives and mothers must stay at home. This observation leads us to postulate that it may be necessary to provide information and education to village citizens and the husbands of prospective women participants prior to the beginning of women's training, in order to assist them in changing their traditional representations of gender. The prevalence of gender stereotypes in a location depends partly on cultural settings. In Europe, Latin countries are more exposed to such stereotypes and, as noted with regard to Spain during the same time period (Lopez \& Morales, 1995), we can add that older groups and groups from rural areas have higher scores than young, urban populations with regard to gender stereotypes. In Lançadeira, we find both: an aged population and a rural setting. Participation in adult education programmes is a way for women to obtain a little freedom, a bit more autonomy. But some women stay dependent on their husbands and on their families' patriarchal logic, traditions, and discriminatory views, including those traditions and views that govern access to knowledge (Ollagnier, 2008, 2010).

As in many similar programmes, the ultimate purpose of the Lançadeira educational project was to facilitate the creation of small enterprises. This was to be accomplished, as it had been with the European NOW (New Opportunities for Women) projects, through a programme built in a training network context and based on experiential and active learning. The authors have been involved in the evaluation of a NOW project in France that is focused on women and training for business creation (Bachelart \& Ollagnier, 2000). In that project, the two foci were the creation of activities in rural areas and the transformation of women's place in local and regional territorial development. Similar difficulties were observed in that 
project as in Lançadeira, and the problems identified in both projects fit with the results of research conducted in similar contexts in other countries.

The conditions for success start with the organisation and conception of the educational programme. In the Lançadeira case, we note that the programme's purpose was not only to facilitate the creation of micro-enterprises, but also to insist on the maturation of the group and of each participant.

The first difficulty is entry into the programme. Aside from resolving the family concerns mentioned above, entry for women entails addressing their own perceptions of their knowledge, skills and abilities. The prospect of returning to school is frightening for most women, even if they already possess educational qualifications. This fear has often been analysed, including in the context of access to universities (Merrill, 2009). Both the trainer and the group play a determining role in helping women obtain confidence in what they can learn and do. Working to acquire knowledge is very important. In Lançadeira, the use of cultural traditions, as well as reference to the colours of nature and local architecture, facilitate such acquisition. Women have a great deal of experience in many fields and have learned much through their lives; these accomplishments must be valorised. There is always a balance that must be found between expanding on what students already know and the acquisition of new knowledge and skills, such as a foreign language or accountancy, as mentioned above. The other fear is that of venturing outside the home and accepting the proposition that leaving the house daily is possible, even pleasant. In Lançadeira, the travelling the participants undertook could be considered as signs of both freedom and an abandonment of the family. In some of the NOW projects, women had previously only ventured out with their husbands, following them to public spaces on occasion. To participate in a training programme means acquiring a new, and sometimes frightening, level of autonomy in space and time. In several cases in Lançadeira, as well as in the NOW programs, we note that the training programme pushed women to obtain a driver's licence in order to retain this geographical autonomy.

Aside from the fact that women have to cope with their external environment, find solutions to childcare problems, organise domestic activities, and confront their husbands' moods and their families' or neighbourhoods' more or less negative reactions, the learning process itself can be an obstacle. There are three strategies that should be given priority for this process to be successful and for training programmes to overcome the obstacles women face. These strategies are linked to a conception of recognition (Honneth, 2000) that we find especially relevant for women's training programs, even though the research that supports this conception did not refer to gender, as noticed by Frazer (2012).

The first strategy is to reinforce self-confidence. This entails trainers discovering the best ways of introducing adapted learning activities and positive ways of evaluating them. To succeed in something is the best guarantee of the learner's success in other learning situations. The second strategy is to encourage the development of self-esteem. Self-esteem grows, for example, through manifestations of solidarity 
and the expression of collective support in the group of learners. For this to occur, trainers must develop learning activities that help build cooperation among women. Sometimes, such cooperation is not easy to build and leadership or other kinds of conflicts might emerge, as mentioned in the Lançadeira context. Pertinent to this point is the fact that being in a group without men is itself helpful to women. In such circumstances, women do not need to face stereotyped, gendered and devaluing attitudes on the part of men and can find similarities in other women's lives and common questions pertinent to the learning process. As they gain self-esteem, women generally awaken to the injustice of their situation and their determination to learn in order to change their lives increases. The third strategy, which is especially relevant in the case of a training programme conceived to spur activity, is the development of self-respect. This means the learner must create a critical vision of existing societal norms and be capable of overcoming those norms. For the women involved in such programmes, this entails integrating the fact that they can occupy a new place in the public sphere with the reality that they possess autonomy and can command respect from the community by reference to their decisions and actions.

After the training is completed, the main problem women face is negotiating the success of their project. In the Lançadeira context, a financial subsidy was planned, but this in itself did not solve the problem. Generating business always requires acceptance and recognition of the enterprise among the different sectors of the local economy. In Lançadeira, as in other situations with which the authors are familiar, such as Van der Gaad (2004), it took a considerable length of time for these women to reach a real and fully-recognised place in the life of their community. As has long been recognised in the management and gender literature, women have to do more than men do to succeed and to obtain valorised employment. In rural areas, the challenge is to convince the neighbourhood, politicians, economic partners and the larger world. It takes time and energy and it requires self-respect. For many women, this entails large changes from how they allowed themselves to be perceived before the process of learning took place; that is to say, they had previously only allowed themselves to appear as spouses ('the wife of ...') and mothers. They have to succeed visibly and flawlessly in taking responsibility and initiative in the community. In Lançadeira, the fact that they successfully adjusted their production to local conditions proved that they understood the market, demonstrated they were capable of efficiently organising a local fair, and running as candidates for formal elections contributed to this public recognition. Most of the time, we must add, initiatives taken by a group of women who have undergone together the same training programme more powerfully affect a community and are more likely to be understood as a positive factor in local development.

\section{NEW ROLES FOR WOMEN IN A LOCAL ECONOMY}

For a wider understanding of the problem of women's economic emancipation within learning spaces, it is necessary to refer to the question of women and development 
in other parts of the world. Feminist research has regularly addressed and analysed this topic at international conferences, such as those the University Institute of Development annually organises in Geneva, and in subsequent publications (Verschuur \& Reysoo). In reviewing this work, we see how, in other contexts, official and institutional attempts to advance the status of women in the life of a community, including through the means of educational programmes, are insufficient, and how networking among women does guarantee their emancipation. Occidental countries have sponsored development projects in poor countries, that, for about a decade, have included a gender component. In those international cooperation programmes, participants engaged in planning, implementation and evaluation activities have had to pay attention to gender questions. Gendered divisions of labour (reproductive, productive, community management and political) must be analysed in the context of such projects to identify practical and strategic needs. For example, the management and use of water is a typically gendered issue, with stereotyped roles for men and women. If official publications lead us to think that gender discrimination and inequality have been eliminated in development practices, those principles are far from being taken seriously on an operational level by either development agents or local authorities (Lausselet, 2004).

Networking among women on a local level is almost the only guarantee that women will take their rightful place in community development projects. In South America, Africa and Asia, feminist movements, involving such feminist leaders as Vandana Shiva, have denounced constrictive traditions and continue to fight for the right of women in rural areas to have a say in the formation of local ways of life that regulate nature, the economy and development priorities. The same types of movement are struggling in urban areas to obtain better working conditions for women, especially in the informal sector, which is known for rendering women's work invisible by refusing to recognise home-based labour as work. More generally, we can also refer to the popular education movement that is based on Paulo Freire's ideas. These ideas, which emphasise the principles that collective reflection creates learning and knowledge brings power, still have their defenders in South America (Korol, 2005 and Pilch Ortega in this volume). However, these initiatives have yet to provide solutions to the global problem of women's need for recognition.

In changing their status, women entrepreneurs must not only face financial questions for themselves, but also must confront how their families and villages view their financial autonomy. In the Lançadeira case, financial assistance was given in the form of wages during the training period (with 30\% of those wages reserved for use by the group) and, thereafter, through a three-year contract that provided a subsidy to the micro-enterprise. If we draw a parallel with programmes in developing countries that attempt to create micro-enterprises, we find incorporated in them the same types of assistance (Merriam \& Sek Kim, 2008). This common feature illustrates the difficulties women generally face. In India, for example, a high illiteracy rate, a lack of mobility, and a lack of access to training generated by socio-cultural taboos and constraints constitute known obstacles to women's 
activities (Lalitha, 1997). This research demonstrated that completion of a prior training programme (offered by NGOs) seemed to guarantee financial autonomy when women were given access to banking credits. But if support and assistance are useful, such tools become efficient when women producers organise themselves into collective groups for "production and learning purposes" (p. 9) and acquire a greater voice in decision-making processes. Some women borrowers face significant problems, such as the failure of their business, or the inappropriate use of the loan. To become accountable for one's own money constitutes a new responsibility that can provide not only a sense of self-worth, but also new occasions for doubts, or for conflicts with members of a group (in case of a collective account) or with one's family. Recent research investigating the role of money in couples' relationships illustrates how money can become a way of integrating, on a daily basis, the notions of equality and autonomy. For Bachman (2009), this monetary facet of a couple's relationship becomes even more difficult when the home is an agricultural property with a mixture of internal and external activities and earnings.

Popular education and training programmes that encourage women's emancipation enable women to move from the private sphere to the public world. If tradition pushes women only to assume a domestic role, events may spur them to organise themselves and act collectively to ameliorate both their own situation and community life in general. In South Africa, women political activists organised themselves in their respective trade unions through networks and forums and played a key role during transitional times. They were able to transform the nature of discussions in the trade unions and to place issues regarding water, childcare, and domestic violence on the unions' political agenda. Subsequently, formal decisions have been taken in favour of gender equality at the national level as well as in local communities (Meer, 2005). Several other examples illustrate the role of groups that start with networking activities and proceed to engage in formal action. In northern Brazil, a community's health association for women became the group leader in saving palm trees and developing women's economic activities. In Indonesia, participating in a network encouraged widows to create a critical analysis of their living conditions and their lack of rights, led them to participate in political life and spurred them to move out of poverty by creating small businesses. But, in these cases, the reality of the nature of relationships inside the home is still in question. The visibility of these women's new public roles and powers leaves us to wonder if the same autonomy is operational at home. In Lançadeira, as in other contexts, it is difficult to obtain the real answer.

\section{THE SUCCESS OF WOMEN AND THE SUCCESS OF THE COMMUNITY}

Lack of access to education perpetuates women's continuing marginalisation from social, economic and political power. A traditional way to educate girls and women can reinforce the subordination of women to men if it is based on neutral, which means male, norms. A training programme for women that aims at transformation, emancipation and empowerment can be perceived as useless and subversive. Globally, 
initiatives taken to organise such training are successful when the learning process is adapted to the participants' experience and when organisers attend to connections with the local economy. Programmes can emerge from a strong women's movement or be planned and financed by national or international organisations. In the latter instance, institutional wishful thinking is not enough to generate success.

Projects must be related to a collective desire on the part of concerned women to change their lives and transform the ways their neighbourhoods view them. This requires that the educational project assume a feminist liberation perspective. For local actors, scepticism will disappear when women prove their efficiency and demonstrate the utility of contributions to the community. In assuming new economic responsibilities, women have become, in some cases, a major determinant of family welfare. They can take on the role of trainer inside the family by sharing new ideas and proposals. Outside the family, in a world built by and for men, women can cease to be oppressed and refuse to stand behind their husbands; they can obtain the freedom to become useful partners in local decision-making and community development.

\section{WHAT HAVE THEY DONE SINCE 2002?}

Conflicts between Laura and Salome led Laura to abandon Lançadeira in 2003. Less than a year afterward, Angel also decided to leave. The remaining two women, facing increasing difficulties in selling their products, decided to close Lançadeira in 2004. However, this did not stop these women. On the contrary, they seized every educational and training opportunity to go on with their lives.

In 2003, the four women registered in a centre recognising prior learning, where they were certified at the 9th grade level. In 2005, three of the women (Salome, Angel \& Maria) participated in a one-year library and archives training programme. They interned in the Tavira municipal library for some months, but there was no chance of finding a permanent job there. In 2006 and 2007, the same three women participated in a programme that provided comprehensive restaurant training. After some months of practical experience, Maria obtained employment in a new restaurant close to Cachopo. Today, she is employed there as a cook and said to have found a new family in the restaurant's owners. Salome and Angel also tried to find employment in this field, but neither found a permanent position. Angel is now working at the day care centre in Cachopo. As for Salome, she was accepted in a training programme on social and cultural animation, which lasted from September of 2008 to March of 2010. This programme gave Salome a 12th grade education. Until 2013 she had been working for the local government and was responsible for Cachopo's cultural programmes.

Laura started a new association, of which she is the director, which connects people engaged in handicrafts throughout a $600 \mathrm{~km}^{2}$ area. The association operates a museum (opened daily) in the city of Tavira that sells and exhibits local products. ASTA also organises, in the Tavira city square, between 20 to 22 small fairs during 
the three months of the summer. Laura has started to act as trainer in the field; she is frequently asked to organise workshops and small training sessions. She also opened in Cachopo a small "living" museum. This is a traditional house, filled with important artefacts, where she also engages in weaving. Laura managed recently (through a project) to have a learner working with her - a young woman. She is also responsible for managing three 'centres of rural world discovery'. Originally primary schools, a project headed by In Loco transformed these buildings into small houses where a maximum of twelve people per house can stay while they visit the area. Laura edited recently a small book of poems: stimulated by a master student who had co-constructed her life history, she wrote her life events in a poetic form. Finally, Laura presented herself as a candidate for local elections in September 2013, for the third time - but this time she won.

\section{ACKNOWLEDGEMENT}

This chapter was made possible in part by the support of the Portuguese Foundation for Science and Technology (FCT).

\section{REFERENCES}

Bachelart, D., \& Ollagnier, E. (2000). Femmes et création d'activité: luttes pour la reconnaissance. Pour, $168,120-129$.

Bachman, L. (2009). De l'argent à soi. Rennes, France: PUR.

Nicole-Drancourt, C. (dir.) (2009). Conciliation travail-famille: Attention travaux. Paris, France: L'Harmattan.

Fletcher, C. (2005). Across the channel: Ongoing training and gender in France and Britain. Gender, Work and Organization, 12(6), 572-590.

Fragoso, A. (2009). Desarrollo comunitario y educación. Xàtiva, Spain: Dialogos.

Frazer, N. (2012). Le féminisme en mouvements: Des années 1960 à l'ère néolibérale. Paris, France: La Découverte.

Honneth, A. (2000). La lutte pour la reconnaissance. Paris, France: Cerf.

Korol, C. (Ed.). (2005). Pedagogia de la resistancia: cadernos de education popular. Buenos Aires, Argentina: Ed. Madres de Plaza de Mayo.

Lalitha, N. (1997). Rural women, empowerment and development banking. New Delhi, India: Kanishka.

Lausselet, R. (2004). Des principes aux pratiques chez les professionnels de la cooperation: une perspective genre. Genève, Switzerland: Université de Genève.

Lopez, M., \& Morales, J.-F. (1995). Gender stereotypes in the Spanish population: Looking toward the future. In L. Amancio \& C. Norueira (Eds.), Gender, management and science. Braga, Portugal: Universidade do Minho.

Meer, S. (2005). Freedom for women: Mainstreaming gender in the South African liberation struggle and beyond. Gender and Development, 13(2), 36-45.

Merriam, S., \& Sek Kim, Y. (2008). Non-western perspectives on learning and knowing. New directions for adult and continuing education, 119, 71-81.

Merrill, B. (Ed.). (2009). Learning to change? The role of identity and learning careers in adult education. Frankfurt, Germany: Peter Lang.

Ollagnier, E. (2008). Gender, learning, recognition. In J. Ostrouch \& E. Ollagnier (Eds.), Researching gender in adult learning. Frankfurt, Germany: Peter Lang.

Ollagnier, E. (2010). La question du genre en formation d'adultes, Note de synthèse. Savoirs, 22, 11-55. 
Stake, R. E. (2000). The case study method in social inquiry. In R. Gomm, M. Hammersley, \& P. Foster (Eds.), Case study method: Key issues, key texts. London, England: Sage Publications.

Van der Gaag, N. (Ed.). (2004). What men and women want: A practical guide to gender and participation. Oxford, England: OXFAM.

Verschuur, C., \& Reysoo, F. (Director). Cahiers: Genre et développement. Paris, France: L'Harmattan. (Annual publication since 2000)

\section{António Fragoso}

CIEO, Research Centre for Spatial and Organizational Dynamics

University of Algarve, Portugal

\section{Edmée Ollagnier}

University of Geneva, Switzerland 



\title{
13. RESEARCHING AND SHARING POWER WITH A LEARNING COMMUNITY
}

\author{
POWER AND LEARNING
}

Whilst many adult educators may think that they operate in relatively power-free classrooms I want to suggest that no forms of education are cushioned from social and economic struggles for power. Rather this chapter aims to show that power is enacted in and around all the educational contexts in which learning is located. Cervero and Wilson $(2001$, p. 11) argue that the struggle for power 'requires us to recognise that adult learners exist in the structurally defined hierarchies of everyday life ...Thus they enter this process marked by their location within larger systems of power and privilege that have shaped their experience.' I will use a case study of a particular adult learning community in order to explore how different forms of power are enacted and experienced and what lessons I learned in the process.

A body of literature that focuses specifically on power and learning in adulthood (Brookfield, 2005; Campbell, 1996; Cevero \& Wilson, 2001; Foucault, 1980, 1982; Hooks, 1998; Luttrell, 1996; Tett \& Maclachlan, 2008) critiques unequal tutor/learner relationships largely through pedagogical and epistemological lenses. The literature shows that social and institutional structures locate teachers in defined hierarchical positions that axiomatically endow them with power over 'their' learners. Drawing from the work of Foucault, Brookfield (2005) argues that regardless of intent, of progressive pedagogies, or of emancipatory ideologies, power is omnipresent, whether we choose to use, abuse or share it with students, and whether it is externally imposed or internally regulated through surveillance and self discipline. Quoting from Foucault, he states that:

The omnipresence of power means we have to accept that all of us, at all times, are implicated in its workings. We must accept that "power is co-extensive with the social body; there are no spaces of primal liberty between the meshes of its network." (Brookfield, 2005, p. 130)

As the 'social body' constructs people/power hierarchies, so it also constructs knowledge/power hierarchies where certain codified knowledges are deemed more valuable than others. So the tutor, as both a person in the structural hierarchy and as a holder of valued knowledge, is the cultural embodiment of the confluence of the two manifestations of power. $\mathrm{S} /$ he is therefore in a position of great power but this may not be recognised. One reason for this is that adult educators often mistake particular 
methodologies, such as the discussion circle, as inherently democratic. What we forget is that this format has simply reconfigured power behind 'surface forms and processes that appear to be free' (Brookfield, 2005, p. 122). Indeed, the power of the discussion leader to indicate approval by nods, eye contact and comments means that a particular type of discourse is privileged and, rather than there being an open discussion, it is in fact highly controlled by the tutor. So what might appear to be participatory practices may inadvertently reinforce the discriminatory practices adult educators try to challenge.

This chapter is based on my experience of working with a group of people who were involved in researching health issues in their communities as part of a learning programme. It discusses the challenges involved in sharing power with people whose previous experiences have told them that they cannot easily learn new things. These experiences have been mainly derived from poor experiences of compulsory schooling and/or unhappy childhoods that, as many studies have found (see Barton et al., 2007; Cieslik, 2006; Tett \& Maclachlan, 2007; Worthman, 2008), have left them with not only low literacy skills but also low self-confidence.

The framework for understanding power is derived from Starhawk (1987) and used to examine and learn from the difficulties experienced in sharing power with this particular community of learners. Starhawk's framework comprises three kinds of power: power-over, power-with and power-within. As a tutor/researcher I have all these types of power and in addition hold the power derived with my position because this gives me the formal authority over others to determine the research agenda and curriculum content. Power-over is defined as the situation where people have power over others and this is sustained by social, economic and political systems and by policies and assumptions about which groups have a right to hold power. Power-with is about one's influence in a group and is based on respect, not for the role or position, but for the person as an individual who can make suggestions, and be listened to, as one amongst equals. I can only have this power if my fellow learners know me as a person that they can trust. Power-from-within comes from being able to say 'I can' and is about a belief in our capacities to use and develop our skills, knowledge and attributes and offer them to others. This kind of power assumes that different people have different kinds of knowledges but that all can contribute equally to the project being achieved.

\section{HEALTH ISSUES IN THE COMMUNITY}

The 'health issues in the community programme' involves people from throughout Scotland investigating their concerns about local health issues. Health is widely defined to include social, mental and physical health and the emphasis is on the structural factors that cause ill health. This is because research has shown that poor health and premature death is caused by inequality and poverty and the ways in which these material conditions cause psychosocial stress in early life (e.g., Marmot \& Wilkinson, 2006; Wilkinson \& Pickett, 2010). These stresses translate 
into inequalities at birth that are exacerbated in later life because the most advantaged social groups use universal medical services more and so they are less available to those that are poorer. This is known as the 'inverse care law' (Tudor Hart, 1971) and it operates because more advantaged groups have better access to the resources of time, finance, and coping skills than those that are poor. It means that advantaged people are able to avail themselves of help to, for example, give up smoking and can also access preventive services such as immunisation, dental check ups and cervical screening more easily (Macintyre, 2007, p. 8). The place where people live also has a fundamental impact on the quality and meaning of their day-to-day life and health. These include social relations with people, the physical fabric of the locality and the local geographies of services and facilities. Research shows that, in combination, features of place can be either sustaining or undermining of psychosocial well being and health (Gattrell et al., 2000, p. 166).

These understandings of health inequalities are foregrounded in this programme so that it is based around local people using their lived experience of problems in their communities to investigate the health issues that they think are having a negative impact on their lives. It is particularly effective in bringing about change as it provides opportunities for people to conduct research and present their findings to key local policy makers in ways that are designed to raise the issues, move them up the policy makers' agendas and suggest solutions to the problems identified. Topics that have been investigated include: poverty; housing; support for people that care for elderly family members; children's play facilities; availability of fresh fruit and vegetables; racism; coping with stress; the impact of pollution. Once a group has identified what health issue to investigate my role is to help them carry out the research that will help define the problem. I see this as a process where the different parties bring different kinds of knowledge. These knowledges are focused around the technicalities of research processes on my part and on their part the experiential knowledge of the health issues in the geographical community in which they live.

However, trying to do this in a way that did not privilege my codified, powerful knowledge over their experiential knowledge was difficult. In the next section I will work through the process that I took with a group that was focussing on the lack of play issues in their area in order to explore the mistakes I made in trying to move from a position of 'power-over' to 'power-with.'

\section{LEARNING TO SHARE POWER}

I found sharing power much more difficult than I expected even though I was committed to a democratic process of negotiation. The main problem was that I had a tendency to thrust responsibility onto the group rather than gradually devolving decision-making power. For example, the group decided that the first step they should take was to investigate the play spaces that were available in the area and we had a brainstorming session to identify the questions that should be asked in order to get the views of local people. I acted as scribe for this on the grounds that many of 
group were not very confident about their literacy skills and also so that they could focus on the discussion. I had forgotten though that standing in front of the group and writing gave me a really powerful position. This was because it both set me apart and also shaped the discussion through the words that I wrote down. At the time no one in the group pointed out my dominant position. What happened was that, as the session went on, fewer and fewer people contributed so their silences were the main way in which they could indicate their lack of agreement. Starhawk notes that:

An empowering group does not thrust responsibilities on people without preparation, but creates situations in which information, skills, and the knowledge gained by experience can be passed on. (1987, p. 272)

I was trying to devolve power by thrusting it onto people without preparation and actually using my position-power to force a decision about what should be included in the questionnaire. However, the group did not yet want to make this decision because, I discovered later, they were not clear about what they should ask other members of their community. Rather they wanted to discuss this amongst their family and friends in an informal way first.

In the next session a couple of members of the group reported that they had been having these informal discussions just to see what reactions they had from those they knew well and the whole group were then able to chip in with their views. I found this discussion really interesting but rather than letting the group develop it further I thought that they should now carry on to develop a more formal questionnaire. In the earlier brainstorming session two of the students had been clear about what they thought should be asked about the play spaces so I tried to get them to take the lead. However, this was also unhelpful because it required them to move from being part of the group of students into being more allied with me as the tutor and I was merely trying to make a shift in who had 'power-over,' rather than initiate a shift to 'powerwith.' In both these sessions the students were reluctant to speak up about their views, they said in a later discussion, because they worried that they might differ from mine and the differences in our 'position-power' had silenced them. I realised that I needed to create a safe environment where the group could risk speaking about their own views in contradiction to mine in spite of these power differences. This meant that I had to really listen to their silences and learn from these unspoken thoughts. I also needed to be aware that, as Foucault argues, 'there are no relations of power without resistances; the latter are all the more real and effective because they are formed right at the point where relations are exercised' (1980, p. 142). So the silences were examples of resistance to my 'power over' the student group.

In these first two sessions, when I attempted to devolve power to the group, students voiced their responses among themselves rather than raise them when we met and, given my position power, this silence is not surprising. Ellsworth (1989) suggests that differences in people's power will consciously or unconsciously influence their decisions to speak. To speak up at the meetings would have meant publicly disagreeing with me. Creating safe environments where people can risk 
speaking in spite of power differences is essential if power is to be shared. In the questionnaire discussion, I did nothing to invite dialogue or to make it safe and comfortable for people to express their views. To listen is to be on an equal footing: listening means putting yourself into the place of the other.

According to Starhawk, power-with is one's influence in a group. It is 'the power of a strong individual in a group of equals, the power not to command, but to suggest and be listened to...' $(1987$, p. 10). Power-with is based in respect, not for the role or position, but for the person. Norton (2001) suggests that personal power is increased when educators become real persons to learners and feelings of friendship and loyalty develop. In the group we began to achieve this by finding opportunities to relax and talk over the issues outside our formal meeting place. One opportunity was when the group took me around their town to show me all the sites that could potentially be play areas. Taking time to get to know each other through the site visits was a step on the way to our becoming more equal especially in relation to the different knowledges we had. These site visits provided an opportunity for the students to introduce me to other family members and friends that we met as we walked around the town and so we could chat together as equals. It also provided a way in which I was able to gain more understanding of the web of relationships that were operating in the community.

However, there were times when I had to exercise my position-power openly and responsibly. For example I had technical expertise about research methods and data analysis. It was important that I was clear about this and explained what I thought would work. This included, for example, what it was possible to ask in questionnaires and the importance of deciding in advance how the resulting data could be analysed. I had this insight into how I was exercising my power after spending some time asking leading questions that presumed the group would eventually realise the 'right' answer. This was really another way of asserting my 'power-over' rather than seeking 'power-with' and could be seen as a form of manipulation. Arnstein (1969) suggests that manipulation is a form of non-participation that substitutes for genuine participation and enables 'power holders to "educate" participants or engineer their "support" (1968, p. 217).

As I recognised the negative impact of my habit of asking leading questions, I began to state my views directly and my ideas were taken up or not, depending on whether people valued them. What I had to be very clear about was why I was suggesting things should be done in a particular way rather than simply relying on my research expertise to assert my authority. Power-with began to emerge once I was able to acknowledge that the people in the group had abilities, interests, talents and knowledge about who they could ask questions of, where they could be found and what questions might be difficult to ask. What finally worked in this devolving of power was when we all spent time working out as equals what we wanted to ask and then finding a way of analysing these questions. This process then became a genuine collaboration and meant I was able to shift from a power-over to a powerwith position. So we were able to bring our different knowledges together as part of a community of practice. 


\section{LEARNING AS SOCIAL PRACTICE}

As I have shown creating a supportive environment where learning opportunities can be maximised through making joint decisions about content, methods, and activities and sharing experiences is not easy. My task was to negotiate the curriculum in interaction with the group, to fine-tune it according to the individuals involved, and to be responsive to the students. Students were encouraged to learn by listening to each other talk about their home and community lives and other factors that matter to them, by sharing the problems that affect their learning and by carrying out the research that would enable them to change the issues that had an adverse impact on their lives. This type of participation can encourage what Barton and colleagues (2007, p. 111) call the development of 'social confidence ...that concerns not just a person's confidence in what s/he can do, but in who s/he can be in relation to others'.

Learning in this way has been extensively examined in the work of Etienne Wenger (1998, pp. 4-6) where he characterises social participation as a process of learning and knowing that presupposes action and participation. The components of his model stress the following:

Meaning: is characterised as a way of talking about our changing ability individually and collectively - to experience our life and the world as meaningful. In this project the action that people were taking together to improve access to play spaces was meaningful because it addressed a problem that had been impacting on their own health and that of their children.

Practice: is characterised as a way of talking about the shared historical and social resources, frameworks, and perspectives that can sustain mutual engagement in action. In this project our time together as we walked around the community enabled us to develop a mutual perspective that in turn enabled the taking of collective action.

Community: is characterised as a way of talking about the social configurations in which our enterprises are defined as worth pursuing and our participation is recognised as competence. By the end of the project we had all come to see ourselves as equals with different kinds of knowledges that we had used together to demonstrate our competence.

Identity: is characterised as a way of talking about how learning changes whom we are and creates personal histories of becoming in the context of communities. By the end of the project the whole group of us had come to see ourselves as people that had the power to use and develop our different skills, knowledge and attributes and offer them to others in ways that we had not been confident to do at the beginning.

Another aspect of the way in which identities had been changed in relation to our competence was through the valuing of the expertise that we had acquired. This was through our shared understandings of conducting research as well as the personal and social experience we brought and this meant we were able to negotiate new learning identities as people who knew and understood and could therefore take action to change things. As Bartlett (2007, p. 53) argues 'individuals make claims about who they are by aligning and contrasting themselves with others' and becoming part of a 
community of practice that was orientated towards learning had positive affects on participants' ability to engage. This in turn had a strong impact on those members of the group that had seen themselves mainly though the lens of school failure and instead repositioned them as capable learners. They came to see themselves as familiar with learning and that this learning was usable in their everyday lives whereas before their image of themselves had been that formal learning was, to use Wenger's (1998, p. 153) words, 'foreign,' 'opaque' and 'unwieldy.' The students had also become co-producers of meaning particularly as they had conducted their investigations of the health issues in their communities and then taken action to bring about change.

Because, from this perspective, learning is a process that takes place in a participation framework, not in an individual mind, it means that what is learnt is mediated by the differences of perspective among the co-participants. It is the community, or at least those participating in the learning context, that 'learn' under this definition. Learning is distributed among co-participants, not a one-person act. All learning 'takes place in a social world, dialectically constituted in social practices that are in the process of reproduction, transformation and change' (Lave \& Wenger, 1991, p. 123). Moreover, this world is affected by different understandings of knowledge and what knowing is about but, as I have shown, these evolve in the face of events and reflections on these events. In this project the shared goal - to improve children's play spaces - and the necessity of working together to achieve it was important in building a community of practice in which all of us were able to participate as full members.

\section{CONCLUSION}

Sharing power is not easy and, as can be seen, the group encountered many challenges along the way. These included trying to work collaboratively where different people had issues about what they felt should be done. This meant that we had to work hard to get to know each other and be able to challenge each other as equals who all had something to contribute. Another problem we faced was deciding who would be taking responsibility for investigating the issues in ways that built on people's strengths but also enabled us all to take some risks. A particular risk for me as a researcher was how to be part of a group that was an advocate for a particular view and looked for evidence to support this position. I had to realise that I could contribute evidence from external knowledge of the literature to help situate the problem but we also needed to draw on the experiential knowledge of the group about what the issues were in the community and how they might be solved. Similarly for the students sharing more equitable power relations was also risky as it placed them in a position where they had to give up the idea that the 'expert' was always the tutor and learn to acknowledge their own expertise. This was particularly difficult for those who had experienced their schools as places where they survived by passively being told what to think rather than actively participating. 
Helping to create a situation where all are able to claim their power-from-within through acting together to create a learning community can be a transformative process. However, there are many challenges that must be overcome before this participative process can be realised through the processes of social learning. I have found that sharing power is difficult and has to be thought through carefully since it is easy to fall into the trap of asserting power over people in hidden, rather than overt, ways. Moving to power-from-within involves valuing different knowledges, coming together to share and use these understandings and taking risks that all of us will find difficult at times.

\section{REFERENCES}

Arnstein, S. (1969). A ladder of citizenship participation. AIP Journal, 35(4), 216-224.

Barton, D., Ivanic, R., Appleby, Y., Hodge, R., \& Tusting, K. (2007). Literacy, lives and learning. London, England: Routledge.

Brookfield, S. (2005). The power of critical theory for adult learning and teaching. Maidenhead, England: Open University Press.

Campbell, P. (1996). Participatory literacy practices: Exploring social identity and relations. Adult Basic Education, 6(3), 127-142.

Cevero, R., \& Wilson, A. (2001). Power in practice. San Francisco, CA: Jossey Bass.

Cieslik, M. (2006). Reflexivity, learning identities and adult basic skills in the United Kingdom. British Journal of Sociology of Education, 27(2), 237-250.

Ellsworth, E. (1989). Why doesn't this feel empowering? Working through the repressive myths of critical pedagogy. Harvard Educational Review, 59(3), 297-324.

Foucault, M. (1980). Power/Knowledge: Selected interviews and other writings, 1972-1977. New York, NY: Pantheon Books.

Foucault, M. (1982). The subject and power. In H. Dreyfus \& P. Rabinow (Eds.), Michel Foucault: Beyond structuralism and hermeneutics. Chicago, IL: University of Chicago Press.

Freire, P. (1972). Pedagogy of the oppressed. Harmondsworth, England: Penguin.

Gattrell, A. C., Thomas, C., Bennett, S., Bostock, L., Popay, J., Williams, G., \& Shahtahmasebi, S. (2000). Understanding health inequalities: Locating people in geographical and social spaces. In H. Graham (Ed.), Understanding health inequalities. Buckingham, England: Open University Press.

hooks, b. (1998). Teaching to transgress: Education as the practice of freedom. New York, NY: Routledge.

Lave, J., \& Wenger, E. (1991). Situated learning: Legitimate peripheral participation. Cambridge, MA: Cambridge University Press.

Luttrell, W. (1996). Taking care of literacy: One feminist's critique. Educational Policy, 10(3), 342-365.

Macintyre, S. (2007). Inequalities in health in Scotland: What are they and what can we do about them? Glasgow, Scotland: MRC Social and Public Health Sciences Unit.

Marmot, M. G., \& Wilkinson, R. G. (2006). Social determinants of health (2nd ed.). Oxford, England: Oxford University Press.

Norton, M. (2001). Challenges to sharing power in adult literacy programmes. In J. Crowther, L. Tett, \& M. Hamilton (Eds.), Powerful literacies. Leicester, NC: NIACE.

Rogers, A. (2003). Teaching adults (3rd ed.). Buckingham, England: Open University Press.

Starhawk. (1987). Truth or dare: Encounters with power, authority and mystery. San Francisco, CA: Harper.

Tett, L., \& Maclachlan, K. (2007). Adult literacy and numeracy, social capital, learner identities and selfconfidence. Studies in the Education of Adults, 39(2), 150-167.

Tett, L., \& Maclachlan, K. (2008). Learners, tutors and power in adult literacies research in Scotland. International Journal of Lifelong Education, 27(6), 659-672.

Tudor Hart, J. (1971). The inverse care law. Lancet, 1(7696), 405-412. 
Wenger, E. (1998). Communities of practice: Learning, meaning and identity. Cambridge, England: Cambridge University Press.

Wilkinson, R., \& Pickett, K. (2010). The spirit level: Why more equal societies almost always do better. London, England: Allen Lane.

Worthman, C. (2008). The positioning of adult learners: Appropriating learner experience on the continuum of empowerment to emancipation. International Journal of Lifelong Education, 27(4), 443-462. Retrieved from http://dx.doi.org/10.1080/02601370802051355

\section{Lyn Tett}

University of Huddersfield, UK 



\section{ADULT EDUCATION FOR SOCIAL TRANSFORMATION IN NORTH EASTERN ALGARVE}

\section{INTRODUCTION}

In 1974 there was a coup d'état that ended the Salazar dictatorship regime. In this context, Portuguese society changed due to an important social and political transformation process of democratization. In the 80 s there was an important political investment in the creation of a public network of adult education. The main aim of this chapter is to reflect on the socio-educational actions that took place in a northeastern Algarve community (in the south of Portugal) in the context of this network, which was responsible for making the Integrated Project for Regional Development (PIDR) a concrete reality.

The Northeast Algarve is located around the Caldeirão mountain range, in an area of 120,000 hectars (1200 square kilometres), that covers about 1/5 of Algarve. Back in the 1980s, Northeast Algarve was a territory with a very low population density, which had dropped since the 60s. According to the Committee for Coordination and Regional Development of the Algarve (2004), the population decline in the Northeast Algarve, between 1960 and 1990, was of 19\%, in contrast to what happened in the coastline of Algarve. In this period, Algarve's resident population increased, due to mass tourism and the consequent construction boom. However, this increase was valid only for the coastal urban areas, whereas the opposite trend was visible in the inland rural areas. This means that mass tourism created a significant increase in the employment of urban areas which, associated with the decay of rural life, culminated in the migration of the population. This phenomenon exacerbated the ageing of the rural population, worsening the already existing economic crisis. The Northeast Algarve population was therefore mainly composed of elderly and illiterate people.

Northeast Algarve was a rural area that included very small and rather scattered places. It seemed a silent reserve where time seemed to have stopped. Generally speaking, people were dedicated to traditional subsistence agriculture with a low level of mechanization, carried out on small family properties. They had no possibilities to modernize the region's agriculture and make the necessary transitions from a subsistence system to a modern one. Especially among older adults, this rural activity was just enough to avoid the risks of poverty. So it was (and is) common that people's primary economic activity was complemented with other secondary activities. There 
was a gap between the cultural and economic educational dimensions: traditional handicraft, oral traditions or other types of cultural symbols and manifestations were rich and diverse, whereas the local economy was dying and educational levels were very low. Very high illiteracy rates $(38 \%)$ were therefore one of the central characteristics of this area. Although it is a fact that schools were insufficient, we cannot see these rates only as failures of formal education. Some authors argue it is a reflex of the unbalanced regional structure and the specific geographical reality. The geography of illiteracy would coincide with the geography of development's absence (Canário, 2000). It was in this territory that an educational process aimed at raising people's educational levels, enhancing community resources, and recovering traditions took place.

In this context the PIDR was created. It gathered together different institutions to promote local development in deprived contexts marked by migration processes that accelerated the ageing of rural communities. Other problems were related to this, especially social order, economic and cultural problems. The PIDR was associated with a political project of local development. This project was implemented in order to fulfil local people's needs, such as the implementation of literacy courses, the organisation of cultural events, or the encouragement of social practices that provide opportunities to promote development. Development was not reduced to a strict economic dimension; rather, education, health, employment, environment or culture were a part of a systemic whole, which through cooperation could give value and meaning to local contexts (Canário, 2000).

\section{THEORETICAL FRAMEWORK}

The establishment of a democratic regime in Portugal allowed several transformations in Portuguese society to be carried out. In consequence of these changes, the educational system was submitted to profound changes. According to Stoer (1986), the relationship between democracy and education was fundamental for the construction of a democratic society. At the end of the 70s, adult education began to gain more visibility, reinforcing the concept of lifelong education, understood as an institutional movement, a political-institutional project towards social change (Finger \& Asún, 2003). The educational movements that emerged in this particular historical period found in lifelong education a political guide with strong links to the promotion of democracy, freedom, liberty and equal opportunities for all. This historical context allowed, therefore, the establishment of strategies of selfmanagement of local institutions, aiming for the production of knowledge that could be used by the people. In this process of democratisation, development emerged out of the participation of adult learners (Melo \& Benavente, 1978).

The public network of adult education was created in Portugal in 1978. In 1979 regional structures were created to respond to an assessment of needs in the field of adult education, including forms of assistance, recruitment and training of adult educators (DGEP, 1979). Also in 1979, parliament approved a plan (National Plan for Literacy and Adult Basic Education, hereafter PNAEBA) to tackle in 
the following decade the low levels of literacy of the population, and to promote territorial approaches to development, among other dimensions of adult education. Although the general results of this plan turned out to be poor, new methodologies for territorial development based on the concrete situation of communities were created - methods that relied on a broad notion of regional and local partnerships, which included Town Halls as a privileged partner of adult education (Silva, 1990). In the context of the PNAEBA, Integrated Projects for Regional Development were created (DGEP, 1979). The Algarve PIDR included institutions responsible for regional management in different dimensions of public life: education and adult education, health, agriculture, employment and training. The main purpose of this project was the social transformation of local communities, the raising of educational levels and the encouragement of collective participation. Adult education was considered a central instrument to promote local development activities. The main aim of it was to create a society where everybody could learn. It was an institutional movement, a political-institutional project and, perhaps, a discourse on social change (Finger \& Asún, 2003).

In this wider context, literacy was considered as the very beginning of a permanent process of community intervention. Literacy is considered as a primary strategy whenever the educational levels of the population are low, and a pillar of learning life-wide, as it is essential to human development and to the improvement of people's quality of life (Pinto, 1997). Literacy means processes that can speed up the learning of reading and writing in a first basic phase. However, a more advanced phase of the literacy process should offer people new possibilities for communication, access to culture and training and, especially, new possibilities to participate in public life and build a critical awareness (Brandão, 2010). In this sense, also Freire (1967) states that literacy processes are but a part of a political project that assures to each person the right to positioning themselves with a critical attitude in regard to social reality. The literacy model developed in Northeast Algarve corresponds to what Fernandéz (2005) calls a social dialogical model. It does not reduce itself to the learning of reading and writing. Rather, it is intended to develop social competences, such as critical thought, the ability to interact with others, and to participate in community life. In this model, learning is centrally characterised by its social dimensions.

According to Melo (1985) it is not enough to teach reading and writing; there is a body of knowledge that is essential in order that people are able to feel more comfortable in the society they live in. Canário (2000) states that adult education in the context of literacy and community animation, is a key factor of local development. According to Fragoso (2005) the local represents a space of places where different events, social practices and phenomena take place. It is the locus of social life, which provides opportunities to concretize actions and to promote development. Local development in this sense would represent a process in which the population of a territory has the opportunity to start future projects in a flexible and open way through a set of actions that increase their levels of confidence and self-organization and improve the quality of life for people of that territory. 


\section{METHODOLOGY}

In this research we used narrative interviews of educators, and focused on their work and experiences in North Eastern Algarve. The narrative interview is considered a form of unstructured, in-depth interview. In the narrative interview the informant is asked to tell the stories concerning an area of interest in which (s)he participated. The narrative interview begins by a generative question which relates to the topic of the study and is intended to stimulate the interviewee's main narrative (Flick, 2005). In the narrative interview people are asked to tell, describe and narrate stories of their personal and/or professional life, giving us their versions of the experienced reality in a first-hand account (Poirier et al., 1999). According to Bogdan and Biklen (1994), this method is characterised by the attempt to re-construct people's life courses, establishing relationships between a person's life experiences and events, interactions with other persons or collectives, or institutions. Kelchtermans (1995) states that people tell their stories, giving account of the meaning those stories had for themselves, in a narrative form.

Many authors have advocated the use of this approach (Denzin, 1989; Atkinson, 1998; Kelchtermans, 1995; Clandinin \& Connelly, 2000; Flick, 2005). They state that stories are a recently opened field of interpretive possibilities for educational research. According to Clandinin and Connelly (2000) people are storytellers and, both collectively and individually, they are characters in their life stories. Flick (2005), states that the narrative interview opens to the researcher a more comprehensive approach to the experiences of the interviewees. The first questions are generative in order to stimulate interviewee discourse. These questions should be posed in such a way that the person talking can grab the proposed themes and make them central according to their experiences. Also Guerra (2006) notes that people share, in a determined historical moment, a set of common beliefs, of common collective interpretations. In this sense, a narrative interview would only be possible when the narrator detaches themselves from the collective history, engaging a personal discourse structured by themselves. According to Atkinson (1998), the interviewees remember and tell what they want the interviewer to know about them, which means that they can omit either voluntarily or involuntarily, issues and events that might be relevant. According to Galvão (2005), the narrative interview as a method of investigation requires an approach based on the interaction between researcher and interviewee, a set of relationships based on mutual trust and acceptance of the importance of collecting data. Although each narrative story is singular, every life story is part of a collective history of the adult education network. In this particular case, this relationship was facilitated by the fact that the interviewer was a colleague of the eight interviewees, 25 years ago, precisely while working within the network of adult education.

\section{ADULT EDUCATION AS AN INSTRUMENT OF SOCIAL TRANSFORMATION}

Before the PDIR was implemented there was a mainstream idea that local administration should solve all problems of all citizens. In practice, this was an 
invitation to people's passivity as there was never a collective organisation to tackle a community's problems. Therefore, it was necessary to define strategies that would lead to a growing mobilization of community groups. It was necessary to promote common communication spaces that could culminate in effective community networks. Literacy was the first step towards the construction of such spaces. The processes of literacy triggered in Northeast Algarve were to contribute to a better interaction between people and groups, stimulating the population to face their community problems and trying to foster a more active intervention of the adults in community life, taking the knowledge of adults and their experiences as cultural sources. Between 1985 and 1990 there were each year about 40 courses of adult education in the Northeast Algarve. Most of these courses took place in scattered places over the hills of the Northeast Algarve, often with difficult access:

There wasn't a paved road (...) it was 20 or 30 miles of bad road (...) it was a real adventure. And when it rained? It was really torture (...) I drove at night, dark night, sometimes I was frightened, without seeing not one car, one person, if something happened (...) I think even thought about it (...) I was so involved in that work I did not think the worst. (Etelvina)

In a territory where the illiteracy rate was about 30\%, literacy was the biggest challenge to the adult educators. Some courses were done in very precarious conditions. There were several courses that took place in homes of adult learners.

The course of Castelhanos was in the house of one person (...), usually the furniture was a chest, a table, and chairs. (Rosário)

The interviewees state that literacy was the more important work and the main reason for personal and professional satisfaction. They emphasized literacy as an achievement that had practical effects for many people, especially for those who needed a license to solve their professional situation. The interviewees also stress that literacy has helped many people to raise their self-esteem and improve their quality of life:

To go back to school meant a lot to those people. (Celia)

The motivations were very different; many had the dream of having the 4th grade. (Rosa Forra)

PIDR objectives were therefore to have a continuum, from literacy to lifelong education. In the beginning, learners were mainly young.

The first literacy groups were composed of women between 30 and 40 who could not read. They were my students' mothers. There were also some men, exemigrants. Still, there weren't many elderly people in the first groups. (Teresinha)

Most of them passed the 4th grade exam and some continued their school path through evening classes. But in a second phase also older adults began to engage in literacy courses. It was possible to find in the same course the grandmother, the 
father and the mother of a certain child. More common yet, some children went to literacy courses with their grandmother / grandfather. Soon there were more than 40 literacy courses spread across the several locations of the area of Northeast Algarve. Literacy and adult education, during that historical period, were considered to be synonymous. In fact, most activities of adult education that were organised later had their origins in the literacy courses. So literacy was the first step for people to get out of their households, to give voice to their opinions and experiences, to overcome feelings of low-esteem or inferiority. For most women, literacy courses went far beyond learning to read and write:

People were happy to be there because it was not just learning to read and write (...), we discussed various topics, I took several things to discuss, people liked those discussions and we had such gatherings. People liked being there, liked that bit of the day. (Celia)

After the literacy courses, social-educational courses were organized, symposia, thematic sessions, socio-cultural entertainment such as movies, poetry meetings, traditional festivals, dances, and cultural gatherings were rediscovered. Poetry meetings, in particular, were much appreciated; in each place there was a poet ready to say his/her poems, despite the fact of being illiterate or not. The elderly were considered as synonymous with knowledge, experience and wisdom; in a way, they were the centre of cultural activities of a distinct nature. Adult education as a whole gained a new dimension in Northeast Algarve after the literacy course process was launched. There was continuity in the learning opportunities people had at their disposal. One of the initiatives that came out of the literacy courses was the implementation of programmes of social tourism, open to everybody living in the area, so that people had the chance to get to know other regions of Portugal. The economic dimensions were also considered in these processes of local development. To face the already existing serious problems in this regard, the coordination of adult education created training and educational courses. The majority of these courses were based in local cultural activities, or in professional activities considered to be on the verge of extinction. For this, the technicians from the Institute of Employment and Training were essential. The coordinators of adult education also organised other types of courses (called social-educational courses), targeted to the elderly and the women who lived in isolated places spread out over the area. These were an alternative to literacy courses. The main aim was to break the deep social-geographical isolation of the people, by giving them the opportunity to perform different activities in groups. These activities were intended to have a social purpose and, in certain ways, to contribute to giving value and meaning to the knowledge and skills the people had. The focus of the action was, therefore, the group, the collective:

(..) a basketry, five needles socks weaving workshops activities, ran as an adult education initiative (...). The Northeast Algarve region had a rich craft 
activities programme, but it was unprofitable. The craftsmen and -women were older people who no longer worked in the fields (...) In the beginning, when the workshop opened, people went there and chatted. It was a meeting point for men and women. The school children also made visits to the studio with the teacher. The idea was to create organised tourism in order to visit the mountains. There was much talk about making a crafts route. (Teresinha)

Summarising, our results show that literacy processes were indeed the basis of a rejuvenated dynamic that took place during the decade of the 1980s. Also relevant were the effects that these educational processes had in promoting a better understanding of citizenship. Populations were able to learn to participate in social life and truly be the engines of such changes. The educators who worked in adult education during this period tried to provide the learning opportunities - non-formal and informal - that allow people to engage in processes of social learning. In a sense, they all assumed that lifelong learning had a solid meaning and that adult education, taken in the light of this paradigm, could help them in their life paths. A pair of literacy courses and activities for youth, a program of social and cultural activities which consisted of a diverse set of activities that included the celebration of traditional festivals, craft exhibitions, film series, theatre, musical gatherings, meetings of poets, were developed into popular, cultural evenings.

That day was party on earth (...) it made sense, because the geographical isolation was so great. Was and is. The notion of interiority was so strong that people saw themselves abandoned (...) that party was that day. (Rosario)

Adult education contributed to revive the latent festive sense that existed in people.

In all activities there was an excuse to make a party, for socializing, for poetry, for singing. (Célia)

Adult education promoted conviviality and playful moments between the local population, an affective-relational atmosphere where people felt relaxed to interact and have fun. According to Fragoso (2005), there are basic cultural elements that function as a resource that people bring to the process, and these cultural elements - if contextualized in the educational process - can contribute to a major goal of animation: stimulating the initiative and participation of individuals and groups in their own development process.

The social intervention triggered by the local coordinators can be considered in two different dimensions: a social-oriented intervention towards literacy, and a broad intervention on the field of social-cultural education. In this sense, thematic activities on health, hygiene, nutrition, family planning and social educative workshops were covered.

We were organizing sessions of health, agriculture, food, social security; and also a socio-cultural activities program according to the needs of people. (Marilia) 
According to Ander-Egg (1990), adult education despite its importance, cannot be reduced to literacy because it is crucial that people are able to acquire the training that enables them to play a leading role in their social, economic, cultural and political life. For Canário (2000), adult education is considered as one of the best instruments to promote local development through the confluence of different practices such as literacy, vocational training, and social-cultural dynamics. To Fragoso (2005), local development should be focused on the interests of the people supporting their participation at all levels. It should promote active citizenship, it should be an educational process linked to the cultural identity of the territory, with elements of local culture. Only then, will it be possible to compare the knowledge, skills, interests, and people's needs to foster the creation of new knowledge, better suited to the dynamics of social change, the ultimate purpose of local development programs.

In this framework the actions of eight educators integrated in the public network of adult education who "steered against the wind" was instrumental to make concrete the Integrated Project of North Eastern Algarve Development, in southern Portugal. The term 'steering to windward', means to steer against the wind: in order to move in the direction where the wind blows from, the navigator is forced to sail in a zigzag. The Northeast of the Algarve has no sea. Those who want to sail in the Northeast Algarve have to learn that in this area there is no sea, but there are bushes, hills, subsistence agriculture, aged people, and illiteracy.

The eight biographical interviews made clear that adult education was a very important experience.

I miss that time (...). When you do what you love and when you see results, you're unaware time is passing, we just think of what we have to do every day. (Etelvina)

It was one of the richest experiences of living life that I had (...) unique learning (...) I loved the experience, it was one of the best periods of my professional life. (Rosa Forra)

I went to adult education because it was a challenge (...) had become a passion (...) it grows on you, it is part of our life. I even put my job ahead of my personal life. (Marília)

I really enjoyed that time, I was very happy (...) people believed in us, we knew we were there for them. (Maria João)

Although each narrative story was singular, every life story is part of a collective history of the adult education network. There were different situations in the life of adult education, because they were experienced at different times, but, there are also common experiences, common places and common routes. 


\section{DISCUSSION}

The Northeast Algarve was in the 80 s a typical example of a rural territory incapable of reacting spontaneously to modernization demands, with huge problems in all dimensions of human experience: economic, cultural, social, etc. The dramatic rates of population ageing, the high illiteracy rates, the passivity of social actors, were signs of the same structural problems. These factors, alone, would be enough for the people of the Northeast to doubt the possibility of fighting collectively for solutions that could improve their quality of life. In this period the PIDR was implemented, which was one of the consequences of a law approved in the Portuguese Parliament in 1979. It was the first structural measure that opened doors to the emergence of dynamics of social change. The existence of the PIDR implicated the building and planning of a project with aims, contents, and adequate methodologies to reach those aims and especially, material and financial resources, which would allow the struggle for education as a right for all, for the improvement of the quality of life in communities. In a territory where the illiteracy rate was about $30 \%$, literacy was the biggest challenge to the adult educators. Between 1985 and 1990 there was, each year, about 40 courses of adult education in the Northeast Algarve: literacy courses, training courses on cultural traditional activities, small community libraries. Most of these courses happened in scattered places over the hills of the Northeast Algarve.

The stories educators shared and re-built allow us to discuss four different points. The first one relates to the notions of territorial development (or local development) that seem to be present in the conception of the PIDR and, more than that, present in the attempts towards its implementation. To organise processes that can contribute to imagine a new and desirable future, in the terms and conditions shaped by the community, assuring that educators keep alive a Freirian dialogue and work with people, corresponds to a certain model of development that grew in Portugal during the 1980s and the 1990s. This is a kind of local development based on popular education, benefiting from a set of characteristics that allows people and communities to be the central collective actor. These types of territorial approaches to development, very common during those decades in Portugal, are in rapid disappearance today (Fragoso, 2011), making it all the more more urgent that we recall stories that bring forth what used to be a valuable dimension of adult education.

Secondly, we should emphasize that literacy processes were, really, the departure point of the global educational processes that went on. The characteristics of the social context made this task urgent and the inspiration of Paulo Freire's literacy methods an adequate way to tackle such urgent problems. Not only because of the high rates of illiteracy, but also because the use of Freirian methods (Freire, 1999) 
allow adults to open the doors of their ability to interpret the world and, eventually, to try to change it. It is, in short, a matter of joining literacy with citizenship, a necessary link in the past and just as certainly in the present and in the future.

A third important point to stress relates to the educators whose stories were told here who gradually transformed themselves into truly Freirian educators. They were able to make significant ruptures with their former paradigms of knowledge and action, which included being specialists in children's education, to become specialists in adult education. These paradigmatic ruptures are usually done with difficulties and implicate the losing of structural features people feel comfortable with. In this case, it seems to us that a certain social and cultural context was indeed favourable for educators to be able to cross their natural limits - and the existence of an organised network to support both their training and their action in the field, providing a supervision context, was crucial. These adult educators were, further, fully engaged in their work and took the side of the people; they tried to contribute to the social change of the territory; and finally, they did not deny the political dimension that intrinsically defines an educational intervention with adults, as argued by Paulo Freire throughout his entire life. Against modern age dark predictions of the end of history, adult educators could, through their experiences, re-build a part of the collective history of this territory.

\section{ACKNOWLEDGMENTS}

To my colleague António Fragoso who reviewed the first draft of this chapter. This text was partially possible due to the support of the Portuguese Foundation for Science and Technology (FCT).

\section{REFERENCES}

Ander-Egg, E. (1990). Metodologia y prática de la animacion socio cultural. Buenos Aires, Argentina: Editorial Hvmanitas.

Atkinson, R. (1998). The life story interview. London, England: Sage Publications.

Bogdan, R., \& Biklen, S. (1994). Investigação Qualitativa em Educação: Uma Introdução à Teoria e aos Métodos. Porto, Portugal: Porto Editora.

Brandão, C. (2010). Que és el método Paulo Freire? In E. Lucio-Villega Ramos \& P. A. Guadas (Eds.), El valor de la palabra: Alfabetizaciones, liberaciones y cidadanias planetarias. Valencia, Spain: Edicions del CREC.

Canário, R. (2000). Educação de Adultos: Um campo e uma Problemática. Lisboa, Portugal: Educa.

Clandinin, D., \& Connelly, F. M. (2000). Narrative inquiry. San Francisco, CA: Jossey-Bass Editors.

Comissão de Coordenação e Desenvolvimento Regional do Algarve. (2004). PROT Algarve: Caracterização e Diagnóstico (Vol. II). Lisboa, Portugal: Ministério do Ambiente, Ordenamento do Território e do Desenvolvimento Regional.

Denzin, N. K. (1989). Interpretative biography. London, England: Sage Publications.

Direção Geral de Educação Permanente. (1979). Plano nacional de Alfabetização e Educação de base dos Adultos-Relatório Síntese. Lisboa, Portugal: Direção Geral de Educação Permanente.

Fernandéz, M. E. (2005). Modelos Actuais de Educação de Pessoas Adultas. In R. Canário \& B. Cabrito (Org.), Educação e Formação de Adultos: Mutações Convergências. Lisboa, Portugal: Educa. 
Finger, M., \& Asún, J. M. (2003). A Educação de Adultos numa Encruzilhada. Porto, Portugal: Porto Editora.

Flick, U. (2005). Métodos Qualitativos na Investigação Científica. Lisboa, Portugal: Edições Monitor.

Fragoso, A. (2005). Contributo para o debate teórico sobre o desenvolvimento local: Um ensaio baseado em experiências investigativas. Revista Lusófona de Educação, 5, 63-84.

Fragoso, A. (2011). Time goes by: An overview of local development trends in Portugal. In A. Fragoso, E. Kurantowicz, \& E. Lucio-Villegas (Eds.), Between global and local: Adult learning and development. Frankfurt Am Main, Germany: Peter Lang.

Freire, P. (1999). Pedagogia do Oprimido. São Paulo, Brazil: Editora Paz e Terra.

Galvão, C. (2005). Narrativas em Educação. Ciência \& Educação, 11(2), 327-345.

Guerra, I. C. (2006). Pesquisa Qualitativa: Sentidos e formas de uso. Lisboa, Portugal: Editora Principia. Kelchtermans, G. (1995). A utilização de biografias na formação de professores. Aprender, 18, 5-20.

Melo, A. (1985). Educador de Adultos: Um gestor de recursos a nível local. Revista Forma, 16. Direcção Geral de Educação de Adultos.

Melo, A., \& Benavente, A. (1978). Educação Popular em Portugal 1974/76. Lisboa, Portugal: Livros Horizonte, 4.

Pinto, A. (1997). Sete lições sobre educação de adultos (10ª ed.). São Paulo, Brazil: Cortez Editora.

Poirier, J., Clappier-Valladon, S., \& Raybaut, P. (1999). Histórias de Vida: Teoria e Prática. Oeiras, Portugal: Celta Editora.

Stoer, S. (1986). Educação e mudança social em Portugal (1970-1980): Uma década de transição. Lisboa, Portugal: Edições Afrontamento.

Joaquim do Arco

University of Algarve

Faro, Portugal 



\section{LEARNING AND LOCAL CHANGE IN SOCIAL MOVEMENTS IN CHIAPAS, MEXICO}

\section{INTRODUCTION}

Social movements as emancipatory movements, the struggle against legal oppression, social discrimination, economic disadvantage and the lack of political opportunities for participation have a long tradition in Latin America. Even in the time of colonialism groups of natives resisted the colonial power, slaves revolted because of the inhumane conditions on sugar cane plantations; the period of the struggle for independence was characterised by violent regional insurgencies (Ismar \& Mittag, 2009). The period from 1900 to 1930 was dominated by labour movement actions and peasant revolts. Central in all these movements was the demand for land reforms and better employment conditions. During the Mexican Revolution in 1910 various groups struggled for change, for instance for "tierra y liberdad", i.e., for land and liberty. Even though indigenous people in different regions participated in the revolution, the ethnic construction of their identity was more or less invisible. In countries with high European immigration, political ideologies, discourses and ideas such as socialism, Marxism, anarchism and feminism were imported from Europe and affected social movements, for example in Chile, Argentina and Mexico. Also some of these perspectives were incorporated into the positions of different political parties and labour unions. Many social change and guerrilla movements arose in Latin America, especially in the 1960s and 1970s. A crucial role was played by the Cuban Revolution as it gave important impulses to other movements (Ismar \& Mittag, 2009). Nonetheless the characteristics of these movements differ widely. In addition to traditional activism based on class or Marxist theories, other groups such as women, Christians and indigenous people started to organise themselves into grassroots movements. With regard to ethnic discourse in such movements, Scheuzer (2007) notes that the presence of an ethnic focus as a relevant category of groups and movements was on the increase in the 1970s in Latin America. In this respect, the author would like to emphasise the fact that the indigenous people, as a very marginalised and excluded group, struggled for their interests in the past as well. They participated in different labour union movements and peasant revolts against governmental repression and exploitation as well as to secure fair wages. As mentioned above, their participation was not ethnically linked at this time (Scheuzer, 2007). 
In the present, the mobilisation of people in social movements occurs along a wide spectrum of motivations. In the past the division into classes and the related social conditions of economic inequality and marginalisation played an important role. Now it can be observed that gender, ethnic and religious membership, in addition to, or related to, social inequality now also becomes a relevant aspect of orientation in current social movements; this is the case in Chiapas in Mexico. Social movements are always part of the social and historical context and they have a strong connection with processes of social change - in the meaning of "reactions" to (for instance) neoliberal change processes or in the sense of social actors who struggle for social change. Therefore an investigation has to pay special attention to the socio-historical and socio-cultural context of each region. In non-European countries, for example, ethnicity appears to be more and more a political resource (Büschges \& Pfaff-Czarnecka, 2007). Additionally the relevance of transnational spaces and international networks for social movements is increasing. Since the end of the 20th century, various resistance movements arose because of heightened social contrasts and social disadvantages which were generated by neoliberal reforms and structural changes. Regional problems and social grievances often cause people to organise themselves, to ask for more rights and call for democratisation. The "new" social movements are less made up of political parties or labour unions; new models of organisations and forms of protest were created (Büschges \& Pfaff-Czarnecka, 2007). An aspect of this development is that public spaces are more often used as political spaces where social injustice and human needs are articulated.

This chapter will focus on Chiapas as a place where a high level of inequality is evident in the dynamics of the social space. Social inequality can be seen in the unequal distribution of resources, educational and career opportunities as well as access to public health services and assistance. Furthermore, the dynamics of the social space are influenced by the economic and political forces acting from outside. Additionally there are "axes of difference" (Achsen der Differenz) - mainly the social constructs of class, ethnicity and gender - which are imbedded in the society; this all too commonly produces inequality in living conditions. In particular, the ethnic construction of being an indigenous person is related both to mechanisms of social exclusion and inclusion. The situation of marginalisation, which mostly leads to the suffering of indigenous persons, has also given rise to social movements in which the situation is analysed and strategies for change are discussed collectively. One of the more famous social resistance movements in Chiapas (Mexico) is that of the Zapatistas, the EZLN (Ejército Zapatista de Liberación Nacional), who sought to draw focused attention to the precarious conditions in their region. Seeking public recognition and shouting "ya basta", they occupied several locations in order to present their demands. They are primarily asking for collective rights in the form of independent administration of their regions as well as healthcare services and education opportunities. In addition to the Zapatistas, other social movements arose in Chiapas for whom the transformation of unequal social conditions is also central. Some of these movements are regional while others are connected with transnational 
social movements, among them Human Rights Watch. The ideology used differs, so sometimes persons who are more involved in their communities are confronted with divergent interests and strategies for dealing with the precarious situation they find themselves in. On the basis of an empirical study and observations during my field investigation in this region, learning processes inside the social movements will be the focus here. Firstly I will describe the social dynamics of the chosen region which are relevant and necessary for an understanding of the development of the social movements in this area. The lack of equality of living conditions is a cause of mobilisation in social movements. Next I will focus on learning processes which are embedded in social movement activities. The social practice of collective analysis and discussion of social conditions, problems and challenges are also interesting as knowledge regarding change processes is produced. This chapter will additionally focus on some of the problems and conflicts which appear when communities are divided by memberships in different social movements. How to deal with these conflicts inside the communities also initiates learning processes.

\section{DYNAMICS OF THE SOCIAL SPACE}

Chiapas is among the richest in resources of all the federal states of Mexico. There are water resources, rain forests, other natural resources such as mineral oil, uranium and precious metals, fertile farmland and "cheap labour" (Kerkeling, 2009). Even so, the distribution of economic and material goods among the population is very asymmetric; a minority owns the majority of economic capital and land and marginalisation, especially of people living in rural areas, is still very high in Chiapas. The research results from CONAPO (Consejo Nacional de Población) show that out of 118 communities in Chiapas, 48 are burdened with a very high level of marginalisation, 39 are at a high level, 29 are medium level, 1 is low and only 1 exhibits a very low level of marginalisation (CONAPO, 2010). People who are affected by marginalisation often do not have access to educational and career opportunities, public healthcare services and other governmental support. As mentioned above, the dynamics of the social space are also influenced by the economic and political forces acting from outside. The interests of transnational companies result in a number of problems: natural resources are exploited, seeds are contaminated due to genetically modified (GM) plants and people are displaced from their communities. Since the debt crisis in Mexico in 1982, the International Monetary Fund (IMF) and the World Bank made their rules for the granting of credits via structural adjustment programmes more strict. This was followed by deregulation of prices, opening up of the domestic market to imports from outside, radical cuts in public sector spending and programmes, etc. The neoliberal transformation of economic politics was driven further during the term of office of Carlos Salinas de Gortari who was president in Mexico from 1988 to 1994. State enterprises were privatised and trade was liberalised even more. The climax of the modernisation project of Salinas de Gortari was the North American Free Trade Agreement (NAFTA) which came into 
effect in 1994 (Schütze, 2009). The situation, in particular for the population in the rural areas, continued to worsen.

As already noted, the precarious situation and the high level of marginalisation also gave rise to various social movements in Chiapas. Simultaneous with the initiation of NAFTA, the Zapatistas called for a turning away from the neoliberal economic policy and they asked for more democracy. The Mexican government reacted with a high level of militarisation. The creation of a paramilitary at the time was also part of a war which is called a "low intensity conflict"; it is intended to destabilise social movements and includes selective repression against the members of these movements. Meanwhile "El Zapatismo" was converted into a transnational movement. All over the world, solidarity groups and networks were founded which still continue to support the Zapatista movement. From the very beginning, the strategies of the EZLN was also focused on the international public in order to create external bases of support and to strengthen their position, their capacity for mobilisation and their chances for survival (Kastner, 2004). For instance the presence of international brigadistas (peace monitors) was initiated to prevent violent actions against communities which participate in the Zapatista movement. There was also a theoretical influence on other social movements, for instance on the Tute Bianche in Italy who try to "translate" the Zapatista policy for Europe or on the group Colectivo Situaciones in Argentina. Other examples are the social network Ya Basta in Italy, the B.A.S.T.A. group in Germany and also globalisation-critical organisations like "People's Global Action" or ATTAC (Kastner, 2004, p. 256).

In 2004 the Mexican magazine "Proceso" published, on the occasion of the 10th "anniversary" of the Zapatista movement, a special edition with the title "La gran ilusión ... la gran frustración" - the big illusion ... the big frustration (Proceso, 2004) with the comment that no significant change had taken place, that the paramilitary groups were more powerful than before, and that observable differences were "only" in small details. The difference can be seen in the fact that indigenous people "leaped out" as principal social actors (Proceso, 2004, p. 3). In fact the "Acuerdos de San Andres" - the agreement between the Mexican government and the EZLN which included several rights for the indigenous people - wasn't implemented as it had been negotiated. The Zapatistas started to build up autonomous regions by creating a "junta de buen gobierno" (council for good governance). Signs calling attention to this read: "Está usted en territorio zapatista. Aqui manda el pueblo y el gobierno obedece. Junta de buen gobierno" (You have entered the territory of the Zapatistas where the people hold the power and the "good" government complies) (Proceso, 2004, p. 3). What is demonstrated here is one of the important decisions of the Zapatista movement: not to cooperate with the Mexican government, with different governmental programmes or the Mexican political parties. What is also becoming apparent is the strategy to build up autonomous areas and to develop independent ideas, structures and policies while attempting to carefully handle power issues. Step-by-step local governments, schools and healthcare services were established. 
Another aspect of the Zapatista policy had always been the mobilisation of domestic and international civil society. They initiated several "events" such as the intergalactic meeting against neoliberalism in 1996 in Chiapas and "la otra campaña" (the other campaign) in 2005 which was intended to enable a broad alliance between several groups and social movements in Mexico. The Zapatista policy of non-cooperation with the Mexican political parties and the government in general provoked criticism as well. Sterr (2008, p. 94) mentions for example that the strategy of the Zapatistas to create autonomous areas in geographically isolated resistance communities manoeuvred them into acting in a political backwater. He thinks that with their "la otra" ("the other") campaign, too few people could be reached and that the recommendation to boycott the election had been the wrong decision. Regarding this, Schmalz and Tittor (2008) noted that Chávez in Venezuela and Subcomandante Marcos of the Zapatistas were two contrasting symbolic figures who showed divergent strategies inside the area of tension between autonomy and etatism of leftist politics, even though both were seeking social emancipation (Schmalz \& Tittor, p. 9). Divergent ideologies and strategies to deal with marginalisation in general can be observed inside various movements in Chiapas. Regarding engagement in change activities, a broader spectrum of motivations occurs along gender, ethnic and religious lines. The "new invasion" of various evangelical and Christian churches in Chiapas intensifies the processes of destabilisation in communities in the rural areas. In the following section I will focus on learning processes in connection with social movement activities and on some of the social conflicts and challenges which appear when communities are divided by participation in differing social movements.

\section{EXAMPLES OF LEARNING PROCESSES IN SOCIAL MOVEMENTS IN CHIAPAS}

How have the motivations of people changed so that they become involved in social movement activities? How do social actors gain agency and create political and public spaces for the articulation or the promotion of their demands or shared visions? What kind of media, symbols and discourse are used inside their cultural politics and how are critical learning processes - individual and collective - initiated through this? All of these questions cannot be answered in this chapter. What I offer are some of my observations, reflections and initial conclusions based on my empirical research which began in 2002 in Chiapas.

My "new" investigation project in this region, which started at the end of 2007, focuses on learning processes and the acquisition of divergent structures of knowledge. One of the relevant sub-themes is individual and collective social movement processes. The data for the empirical study includes about 40 narrativebiographical interviews conducted in Spanish and data which were collected in field investigations. In the context of social movement activities some of the field studies I made in communities in the rural areas are highly interesting. The detailed transcriptions of the interviews are translated from Spanish to German to offer access to my colleagues and to allow them to participate in the interpreting process, and also 
to provide accessibility to the narratives for a larger group of researchers. The process of translation can be identified as a first step in interpretation, perhaps comparable with the line-by-line open coding of the data in grounded theory methodology. The interviews were conducted over two periods, in 2008 and 2010. On the basis of grounded theory as a research style, the data are sequentially analysed and elaborated. The offhand narratives of personal experiences provided in a narrative interview give access to subjective constructions of social reality. Of special interest are informal learning and education processes which have been developed in the encounter with social change. I want to emphasise that the analysis of the empirical data is still in progress. Various activities and forms of interaction, different motivations, strategies and cultural politics appear in the narrative interviews. As was already noted above, the focus of social movements in this region varies from strongly politicised orientations where the precarious situation and/or ethnicity and/ or gender are central to environmental and religiously-motivated movements. They differ regarding their ideologies, discourses used and their strategies for dealing with marginalisation. In general, social movements in Mexico are characterised by a strong local and regional orientation (Schütze, 2009). Social grievances and poverty as well as social transformation processes and other drastic changes are seen as the main causes of social mobilisation.

With the words "to come forward as an indigenous person," one of my interviewees commented on his involvement with a regional social movement. The interconnectedness of individual and collective orientation was highly visible in his narration. It should be added that social involvement still remains an important factor in this region. The lack of a social welfare state, for instance support for the elderly, in many areas induces a higher level of mutual social dependency. Collective orientation can be understood as a principal condition for the survival of social actors. The interviewee furthermore articulated a process of change, but with the perspective of being forced to change - the threatened economic survival of the group entails the need for action. Against this backdrop, the interviewee described learning processes with a high level of transformation: social conditions as well as the subject are part of this transformation. "As an indigenous person" refers moreover to an ethnically encoded strategy - ethnicity appears as a political resource. Biographies of people from this region show that informal processes of learning are confronted with hegemonic forces. Competing profiles of knowledge (Alheit, 1989), unequal living conditions and the phenomena of marginalisation need to be identified and analysed by the social actors. The critical reflection on the regional situation in the global context as well as the transformation of unequal conditions is central. One main aspect can be seen in the practise of breaking open the dominant objectified sense of things. For instance, the ethnic construction of being an indigenous person is related to mechanisms of social exclusion and inclusion. Postcolonial conditions reference an interpretative space where the construction of ethnic membership is more strongly interpreted as a concept of race. In this perspective, the idea of the predominance of "whiteness" is still firmly in place. Therefore in some of the 
discourses of indigenous movements, the term "indígena" as an ethnic construction is liberated from its use in terms of hegemonic repression and given a new context of meaning. The struggle for recognition of difference occurs in several movements in Chiapas - also in the Zapatista movement - but the social construction of ethnicity varies. Ethnic discourses are also influenced by transnational communication and networks between social movements, in Chiapas, also, because of its geographical proximity to Guatemala.

A woman described her learning process in a feminist movement as an individual development process which also provoked changes in her immediate surroundings. Coming from a community where women's rights are not well established, her role in the family changed and her range of activity was expanded. In her case so-called habits and customs (usos y costrumbres) and accordingly traditional gender roles ensure the dominant position of men. This factor needs to be considered in particular in connection with the demand for the right to be different which appears inside ethnicised discourses. Under the pretext of divergent culture, women remain in their oppressed position. The Zapatistas in particular have paid attention to developing women's rights in the communities. Furthermore, the young woman emphasised the development of social and organising skills and the increase in her self-confidence. Also another interviewee who is working as a teacher at a regional intercultural university narrated his experience as a leader of a student movement which he initiated. The enabling of changing processes in his environment and his capacity to mobilise other young people were central in his description. A woman who migrated from the USA to Chiapas 25 years ago described to me her experiences with an environmental group which she initiated in San Cristóbal de las Casas. The small group is struggling to preserve the last wetlands in the periphery of the city. Interesting for me was her concept of citizenship which she somehow "brought" from her earlier experience in San Francisco and which she tried to "implement" into the orientations of her fellow activists. Additionally she told me about the drastic change in San Cristóbal over the last 16 years. The insurgency of the Zapatistas in 1994 meant that San Cristóbal became famous overnight. Since this time the number of bars, cafés and hotels has increased dramatically. The increase in tourism and also the population in general is enormous.

During the visit of a regional governmental organisation, I was also witness to a protest of indigenous people who tried to call attention to social conflicts in their community. At first sight the conflict might be considered to be a religiously motivated dispute. Groups of Catholics of the community were involved in the burning of the houses of some evangelical families. The victims were protesting in front of the governmental offices and demanded that the government resolve the conflict and bring the culprits to justice. Due to the fact that they could not return to their homes, they pitched their tents in front of the court building in order to put pressure on the governmental authorities. In this connection it should be added that in many cases, behind these "religious" conflicts are power struggles between specific families or other groups. Religion functions in many cases as a sort of labelling in 
order to transform structural and informal hierarchies which are established in the community. Young students reported to me that they converted to an evangelical church because of their discontent with the predominance of the Catholic elite in the community. Additionally, the social conflicts in some communities are intensified by churches and other religious groups (their number is increasing dramatically in Chiapas) which are moving into the village communities. More and more this begins to be a serious challenge for many communities (particularly in the rural areas) which are strongly collectively oriented - their collective habits ensured their survival in the past and the collective perspective is still a basic element of daily life.

As a final example I will describe very briefly a community which is divided by different involvement in social movement activities. It is a community which is actually part of the resistance; the majority of the villagers belong to "la otra campaña" (the other campaign) which started in 1996. The village is situated at the site of a former plantation (finca) from which the owner's "escape" caused drastic social changes as some of the workers later resettled the area and started to cultivate the land again. Presently they are struggling for the recognition of their village, especially because of the lack of officially legitimate documents of property ownership. As victims of governmental repression and violent attacks, brigadistas (peace monitors) are present in the community and a 24-hour guard at the entrances of the community was established. As mentioned previously, not all of the families share in this struggle. Some of the families converted to an evangelical church which does not "allow" them to criticise or to question the power of the government. Against this backdrop, daily life and social interactions sometimes produce situations which are highly confrontational. For instance while one group was holding a meeting to discuss their current situation and the next steps in their struggle, the members of the evangelical church arranged a religious event with electrically amplified instruments which filled the whole community with the sound of Christian music, e.g., "Jesus Loves You" and "Christ is with Us." The acoustic disturbance was incredible. Other days I observed that in some houses the volume of the Oventic Radio of Resistance (a radio station of the Zapatistas) was so high that there was a sort of acoustic competition between religious and resistance music, discussions and comments. To my surprise none of the villagers ever complained about the activities of the other group; the social conflict was more latent than open. The ideologies and strategies of the two groups are totally contrary. The majority of the village is struggling to break open their situation of marginalisation and move toward social emancipation and more democracy. Their structures are organised democratically and the strategies are discussed within the community of the activists. Also they established a communal fund for their activities, medical emergencies and other necessities. Inside this group I also noted minor disputes about the economic support which every family has to give to the common fund because of divergent memberships in "la otra campaña" ("the other campaign") or the "base de apoyo" ("support base") of the Zapatistas. 
Due to their adoption of non-cooperation with the government, they use alternative structures for healthcare services, economic trade and adult education. The latently existing conflicts initiate learning processes to deal with the heterogeneity of ideologies, strategies and orientations.

\section{CONCLUDING REMARKS}

The precarious situation caused by marginalisation and poverty gave rise to a broad spectrum of social movements in Chiapas. The examples described above show also that the ideologies, orientations and strategies inside these movements vary widely. Increasingly ethnicised discourses appear as a political resource whereby ethnicity is constructed differently. On one side, the ethnic focus is used as a symbol of discrimination from which a larger group of persons is affected in order to enable alliances between different groups in terms of social change. On the other hand it functions as a marker of differing cultural practices in order to strengthen social habits such as a strong collective orientation in contrast to processes of individualisation.

Biographies relating marginalisation show that informal processes of learning are strongly confronted by hegemonic forces. Competing profiles of knowledge, unequal living conditions and the phenomena of marginalisation need to be identified and analysed by the social actors. These informal processes of learning refer to problemsolving movements in which meaningful references are constructed - in this way new structures of sense are generated as well. In the created spaces of idea exchange, meanings, discourses and importance are negotiated publicly. Social actors occupy and acquire cultural-political spaces which give them opportunities to break open the power of definition coming from the established mainstream. Likewise they have to deal with the persistence of hegemonic structures and the frustration which occurs. The increasing heterogeneity in communities in the rural area additionally requires social mediating processes and the creation of new arrangements to support the coexistence of rival groups. The struggle for social change and equal social conditions needs economic, cultural and social resources as well as time and patience. It should be added that in many cases the persons affected by marginalisation in Chiapas didn't have the opportunity to attend school, that their daily life is characterised by a struggle for survival and that they are subjected to severe repression and violent attacks because of their involvement in social change movements.

\section{REFERENCES}

Alheit, P. (1989). Erzählform und "soziales Gedächtnis": Beispiel beginnender Traditionsbildung im autobiographischen Erinnerungsprozeß. In P. Alheit \& E. M. Hoerning (Eds.), Biographisches Wissen: Beiträge zu einer Theorie lebensgeschichtlicher Erfahrung. New York, NY: Campus Verlag. Büschges, C., \& Pfaff-Czarnecka, J. (2007). Einleitung: Ethnizität als politische Ressource. In C. Büschges \& J. Pfaff-Czarnecka (Eds.), Die Ethnisierung des Politischen: Identitätspolitiken in Lateinamerika, Asien und den USA. New York, NY: Campus Verlag. 


\section{A. P. ORTEGA}

Consejo Nacional de Población CONAPO. (2010). Índice de marginación por entidad federativa y municipio 2010. Retrieved from http://www.conapo.gob.mx/es/CONAPO/Indices_de Marginacion_2010_por_entidad_federativa_y_municipio

Ismar, G., \& Mittag, J. (2009). Vom Protest zur Partizipation? Soziale Bewegungen in Lateinamerika seit Beginn des 20. Jahrhunderts. In G. Ismar \& J. Mittag (Eds.), ?"El pueblo unido"? Soziale Bewegungen und politischer Protest in der Geschichte Lateinamerikas. Münster, Germany: Westfälisches Dampfboot.

Kastner, J. (2004). Zapatismus und Transnationalisierung: Anmerkungen zur Relevanz zapatistischer Politik für die Bewegungsforschung. In O. Kaltmeier, J. Kastner, \& E. Tuider (Eds.), Neoliberalismus, autonomie, widerstand: Soziale Bewegungen in Lateinamerika. Münster, Germany: Westfälisches Dampfboot.

Kerkerling, L. (2009). Migration im Kontext der Transformation indigener Lebensweisen in Chiapas. In E. Tuider, H. Wienold, \& T. Bewernitz (Eds.), Dollares und Träume: Migration, Arbeit und Geschlecht in Mexiko im 21: Jahrhundert. Münsterm, Germany: Westfälisches Dampfboot.

Proceso. Semanario de Información y Análisis. (2004). 1994-2004 La gran ilusión... la gran frustración. Edición especial 13, enero 2004.

Scheuzger, S. (2007). Die mobilisierten Grenzen politischer Identität: Diskurse über Ethnie und Klasse in Mexiko der 1970er und frühen 1980er Jahre. In C. Büschges \& J. Pfaff-Czarnecka (Eds.), Die Ethnisierung des Politischen: Identitätspolitiken in Lateinamerika, Asien und den USA. New York, NY: Campus Verlag.

Schmalz, S., \& Tittor, A. (2008). Einleitung. In S. Schmalz \& A. Tittor (Eds.), Jenseits von Subcommandante Marcos und Hugo Chávez. Soziale Bewegungen zwischen Autonomie und Staat. Hamburg, Germany: VSA Verlag.

Schütze, S. (2009). Klientelistische Strukturen und Kampf um "Tierra y Libertad": Soziale Bewegungen in Mexiko. In G. Ismar \& J. Mittag (Eds.), ? "El pueblo unido"? Soziale Bewegungen und politischer Protest in der Geschichte Lateinamerikas. Münster, Germany: Westfälisches Dampfboot.

Sterr, A. (2008). Modellwechsel mit Hindernissen: Autoritärer Neoliberalismus und Aufschwung alternativer Bewegungen in Mexiko. In S. Schmalz \& A. Tittor (Eds.), Jenseits von Subcommandante Marcos und Hugo Chávez: Soziale Bewegungen zwischen Autonomie und Staat. Hamburg, Germany: VSA Verlag.

Angela Pilch Ortega

Institute of Educational Science

University of Graz, Austria 


\title{
ONUR SEÇKIN
}

\section{SOCIAL MOVEMENTS AND ADULT LEARNING}

\author{
A Story of the Women in the Environmental \\ Social Movement in Turkey
}

\section{INTRODUCTION}

Globalization and social movements are reciprocal concepts where globalization has been a main reason behind the appearance of social movements under different names in recent years. Furthermore, these two phenomena have awoken the interest of researchers in the field of adult education and learning, on the basis of the effects of globalization and changes due to globalization in the field and learning experiences of adults in social movements.

The concept of globalization has become one of the most widely used concepts especially in the last 20 years. For researchers such as Allman and Wallis (1995) who have analyzed the concept of globalization from a political economy approach, it "constitutes the means whereby capitalism reorganizes itself to counter the tendency of the rate of profit to fall, owing to the crises of overproduction" (cited in Mayo, 2003, p. 39). In this chapter, globalization is taken not as a totally new fact but as a new era of capitalism after the 1970s and it is taken here as given that "contemporary capitalist globalization has a powerful impact on every aspect of human life" (Clover, 2003, p. 1). Through the globalization period it has been observed that, while mass poverty has increased in various parts of the globe (Mayo, 2003) wealth has accumulated in the hands of a minority of the world population. Sunmer (2008) states that "to cut through the vagueness and gain greater understanding, one should ask what is being globalized?" and adds "Are women's rights, environmental protection, public education, universal health care, and life security being globalized, or are corporate rights, environmental deregulation, privatized education, cash-and-carry health care and police surveillance being globalized?" (Sunmer, 2008, p. 31).

\section{GLOBALIZATION, ADULT EDUCATION AND SOCIAL MOVEMENTS}

Some of the most drastic effects of globalization can be seen on education, and specifically, in adult education. As Holst (2004, p. 23) states, "Globalization is widely considered to be one of the most important issues facing the field of adult education today." Rizvi and Lingard (2010) state that the dominant view of globalization which is widely referred to as "neo-liberal,' "is associated with a preference for 
the minimalist state, concerned to promote the instrumental values of competition, economic efficiency and choice, to deregulate and privatize state functions" (p. 31). Neoliberal ideology, as a main political economic discourse behind globalization, has converted the adult education field structurally. Sunmer argues that "In a globalized world, adult education takes on many forms, from technical upgrading and agricultural extension through life skills and language training to third-age learning and ecological literacy. But these forms of adult education are not available to everyone" (Sunmer, 2008, p. 23). Borg and Mayo (2005) state that adult education has lived the 'economistic turn' since the late 1980s. Schugurensky (1997, p. 44) as well, emphasizes that "the tendency is towards the commodification of adult education, which is considered less as an inalienable right of every citizen but more as private consumption or a private investment."

It can be said that in recent years similar trends have been seen in Turkey in the context of adult education and adult learning where "the emphasis in adult education has been on vocational education" (Okçabol, 1997, p. 156). The concept of lifelong learning has come into play instead of adult education in this change process, and some very important policy instruments have begun to be implemented. In this context, the publication of the Policy Paper on Lifelong Learning (2006) and the Lifelong Learning Strategy Paper and Action Plan (2009), together with changes to the Non-Formal Education Institutions Regulation (2010), and the foundation of the General Directorate of Lifelong Learning in MoNE (2011) are some important political steps and corner stones of the recent years.

There has increasingly been emphasis on the adaptation of skills to the needs of the global labor market in lifelong learning policies and practices in Turkey. In the Strategy Paper (2009), the focus on the needs of globalization is obvious. The paper talks about a re-definition of education "in line with the lifelong learning approach and the needs of the information society ... under the effect of globalization" (p. 7). In the Draft Policy Paper, which is published within the context of a Promotion of Lifelong Learning Project (a joint project of the European Union and the Turkish Ministry of Education), the concept of lifelong learning is justified on the basis of the demands of the labor market and the need for the adaptation of skills to it (MoNE, 2013).

Adult Education Surveys (AES) which are implemented by the Turkish Statistical Institute provide highly comprehensive data about "participation rates in learning activities, socioeconomic and demographic profiles of participants and nonparticipants, characteristics of learning activities as duration and kind of education, as well as employee support and willingness to participate in learning activities" in Turkey (Turkish Statistical Institute, 2010). The table below presents participation rates of people in non-formal education based on their demographic differences both in 2007 and 2012. As can be seen in the table, participation ratios among those who are 18 years old and upwards increased from $13.9 \%$ to $15.4 \%$ in successive surveys. Table 1 shows that participation ratios are higher among adults who live in urban centres, who are male, who graduated from university and who are high-skilled white 
collar workers. According to the 2012 AES, the reasons for participation in nonformal education activities were stated as follows: "Making their job better $(60.9 \%)$; getting useful knowledge and skills for daily life (34\%); getting information about a topic that interests the participant (33.4\%) and receiving a certificate $(27.5 \%)$ " (Turkish Statistical Institute, 2013).

Table 1. Participating in non-formal activities, 2007, 2012

\begin{tabular}{|c|c|c|c|}
\hline \multicolumn{4}{|c|}{ Participation in non-formal education } \\
\hline & & 2007 & 2012 \\
\hline Total & & 13.9 & 15.4 \\
\hline \multirow[t]{2}{*}{ Settlement Place } & Urban & 15 & 17.8 \\
\hline & Rural & 11.2 & 10.1 \\
\hline \multirow[t]{2}{*}{ Sex } & Male & 17.3 & 17.5 \\
\hline & Female & 10.5 & 13.4 \\
\hline \multirow[t]{5}{*}{ Age group } & $18-24$ & 26 & 26.7 \\
\hline & $25-34$ & 18 & 20.9 \\
\hline & $35-54$ & 11.6 & 14.4 \\
\hline & $55-64$ & 4.4 & 5.4 \\
\hline & $65+$ & 1.2 & 1.4 \\
\hline \multirow[t]{6}{*}{ Education attained } & Not completed school & 2.1 & 3.3 \\
\hline & Primary school & 6.4 & 8.0 \\
\hline & $\begin{array}{l}\text { Primary education and junior high } \\
\text { school }\end{array}$ & 13.8 & 14.4 \\
\hline & General high school & 28.8 & 26.2 \\
\hline & Vocational or technical high school & 27.7 & 26.6 \\
\hline & Higher education & 39.0 & 40.0 \\
\hline \multirow[t]{2}{*}{ Labour status } & Employed & 20.1 & 21.1 \\
\hline & Unemployed & 27.6 & 19.2 \\
\hline \multirow{3}{*}{$\begin{array}{l}\text { Participation in education and } \\
\text { training by occupations }\end{array}$} & High skilled white collar & 32.8 & 37.2 \\
\hline & Low skilled white collar & 24.8 & 21.6 \\
\hline & High skilled blue collar & 11.5 & 11.4 \\
\hline
\end{tabular}

The table shows that, particularly people living in rural areas, with low levels of education and blue collar occupations are still far from accessing adult education activities in 2012.

The drastic effects of globalization have been seen not only in the field of education but in other fields as well, one of which has been environmental issues. As 
Hill (2003) emphasizes, "many of the institutions and apparatuses of globalization, including transnational corporations and multilateral financial groups such as the World Bank, the International Monetary Fund, and the World Trade Organization, have been accused of fostering ecologically and socially destructive development in less technologically developed countries" (Hill, 2003, p. 33) where globalization has enabled "Western capitalist nations to dominate and destroy natural environments like never before" (Clover, 2003, p. 1).

One of the main effects of globalization on environmental issues can be followed through mining policies in many countries. Öngür (2007) states that more than 130 countries in the world have reorganized their mining laws since the mid1980s, Turkey being among these countries. Through changing mining laws, big mining corporations have obtained wide opportunities, especially in developing countries, ranging from rights to mine in places such as forests to the benefits of tax exemptions. In this process, transnational mining corporations have dominated the national mining production while national mining production itself has been cut back (Tamzok, 2003). The mining law of Turkey was changed in 2004, which brought important privileges for transnational mining corporations, because of which this new law has been named a 'colonial law' by many people (Öngür, 2007). Currently, there are many major corporations carrying out mining operations in different regions of Turkey and these corporations use the privileges that the new law has provided them. These corporations do not pay serious attention to environmental protests that have occurred as a consequence of the damage to the environment they have caused.

The Kaz Mountains Environmental Social Movement has been one of the most successful social movements in Turkey in recent years. Especially after the cutting down of trees by mining corporations to open new paths for the gold-mining region in the village of Bahçedere, which is a part of the town of Küçükkuyu in the Çanakkale city area, this movement grew in the region. People began to be organized around the Kaz Mountains Preservation Initiative which supported their claims that commercial operations have threatened their health, their means of livelihood and vital natural resources. The initiative and other environmental platforms that give support, have organized many activities, such as meetings, demonstrations, conferences, visits, etc., to act against the mining operations, to raise the environmental issue and to make their voice heard by the public (Seçkin, 2008).

\section{SOCIAL MOVEMENT LEARNING}

Despite the fact that social movements were not looked at as 'learning sites' for many years, Holst notes "the growing importance given to the relationship between adult education, social movements, and civil society in the literature since the wide dissemination of Freire's ideas beginning in the mid-1970s" (Holst, 2002, p. 77).

While increasingly "adult education becomes a technocratic, market-driven, individualistic sector of the service industry" (Sunmer, 2008) through the effects of neo-liberal policies, social movements - where they have grown as a result of the 
disruptive effects of neo-liberal policies - have provided counter-possibilities for the field as a way of resistance to the new economist trend. Since educational activities play an important role for the success of social movements, they provide critical learning outcomes both for the participants of movements and the public as well. According to Clover and Hall (2000), "social movement learning refers to: a) learning by persons who are part of any social movement; and b) learning by persons outside of a social movement as a result of the actions taken by, or simply by the existence of, social movements" and as Foley (1999) emphasizes, "some of the most powerful learning occurs as people go against oppression, as they struggle to make sense of what is happening to them and to work out ways of doing something about it" (Foley, 1999, p. 2).

Knowledge is produced through debates about meeting agendas, the planning of meetings, campaigns and demonstrations, and exchanges regarding strategies and tactics in social movements (Walters, 2005). As Foley states, the content of learning in social movements

may be technical (about how to do a particular task), it may be social, cultural, and political (about how people relate to each other in a particular situation or about what their actual core values are or about who has power and how they use it). (Foley, 1999, p. 71)

and participants also change their attitudes, beliefs and values due to participating in social movements (Cain, 1998). Besides these common features of learning in social movements, educational activities in environmental movements focus on

central governments' and transnational corporations' disinterest in preserving the fragile relationships between humans and the natural world; the growing inequality between haves and have-nots both within rich nation-states and between lender-states and states in debt to them; the asymmetry of political and economic power; cultural homogenization; over-utilization of the world's resources by an elite group of consumers; genetic engineering; and the impact of turbo capitalism - excesses carried out by techno-organizational change and the free market, through private enterprise that has become uncoupled from government regulations. (Hill, 2003, p. 33)

\section{THE STORY OF A WOMAN IN THE ENVIRONMENTAL SOCIAL MOVEMENT}

In this chapter, one of the most popular environmental social movements in Turkey in recent years, the Kaz Mountains Social Movement, will be analyzed in the context of learning experiences of adults in the movement, through the experiences of one of the active female participants. This woman's testimony has been chosen in this chapter, since she emphasizes the importance of the learning experiences that she experienced in the movement as an active participant. Her expression: "If I had had 
lessons through paying money, I do not know if I could have learnt as much as I learned in this struggle" (Seçkin, 2008), summarizes the value of learning for her.

The data of this study were collected in April 2008 in the city of Çanakkale where the struggle occurred. For the study, 16 semi-structured interviews were carried out; 13 of the participants were villager-participants in the movement and three of them were activist participants. There were 3 participants who did not attend school, 10 who had been to primary school (5 years), 1 high school and 2 university graduates among the participants, and the majority of the participants (14 participants) in the study were olive producers. This chapter is the story of one of the women activists in the movement. A borrowed name, Ayşe, will be used for her in this chapter.

Ayşe is a 42-year-old woman, married and with two children and she has lived in that region for 12 years. Ayşe moved to live in that region after her marriage to a man who was born in a village in which the operations of the mining company initially started. Ayşe completed vocational high school and is a housewife. Her husband is a university graduate.

\section{PARTICIPATING IN THE MOVEMENT}

The interview started with the question: "What did you think when you first heard about gold-mining operations in your environment?" Like many other participants, Ayşe answered this question thus: "The mining people did not say at first that they will mine in this region" and continued with following words:

We learned from villagers that miners came and had begun drilling operations.

I did not have so much knowledge about what mining would bring here. When

I asked my husband about this issue, I learned what it could be. Then I thought that we had a huge problem.

When the reasons for participating in the movement are asked for, Ayşe said that when she learned about the danger of harm to health and to the environment from mining operations because of cyanide, she decided to participate in the movement. Her following words also show her thoughts about how the future of her children played a role in her decision:

I have two children. If I live here, I get my water, my food from this region, and if I want my children to live in healthy conditions, I must struggle.

In the light of the words of Ayşe, it can be said that learning experiences before the beginning of the movement affect the participation in the movement, in other words participation in the movement starts with some knowledge about the problems that may occur.

Ayşe has been part of the movement from the beginning. She has served in organizing educational activities, meetings, and demonstrations. While she has served also as a representative of the Kaz Moutains Preservation Initiative group in coordinating interaction with local authorities and associations, and dealing with 
visitors from outside of the town, she also has had some responsibilities in forming networks for interaction among people. Ayşe is one of the active participants of the movement, and in the light of the general results of the study, it can be said that greater participation in activities in a social movement results in more learning experiences.

In the interview form, the question which aimed to investigate feelings of anxiety or fear due to participating in the movement was: "Did you have any fear at the beginning of participating in this struggle and how did you deal with this situation?" Ayşe stated that since her husband has a public job and this struggle is based on politics in some way, she had some fear at the beginning. She continued with the following words:

Did I think that is it dangerous for the job of my husband? But you cannot live with fear. I said to myself, who cares? If something happens, we have a field, olive groves, and so we will not starve. I thought that if we die, let's die with struggle.

She also emphasized that the huge support around them, from the media, the public, from the universities, played an important role in dealing with her fear at the beginning of the movement. When she is asked for her thoughts about the success of the movement, Ayşe states that, "they will be successful and will continue their struggle even if there is a death at the end."

\section{LEARNING IN THE MOVEMENT}

Three questions in the interview form were directly related to learning experiences of participants in the movement. These questions were: "What do you think about your learning experiences in the struggle? What have you learned?," "Do you have any information about other environmental social movements? Did you learn anything from these movements?," and lastly, "How did you get these learning experiences, in which ways?"

Ayşe stated that she had not been aware of the dangers of gold-mining operations before. She stated that her learning experiences began with her husband's expressions about the dangers of it, especially for people's health, with examples of former operations in other regions. In the interview she stated that after these learning experiences, she started to get to know more about the problem and learned how gold-mining operations with cyanide damage the environment and natural resources such as water, air, and the forest. Furthermore, since the main income of the people in that region is from olive groves, she stated that she learned how these mining operations would affect the income of the people who live there. As an interesting note, she said she used to buy gold to save money for the future of her children and after she learned about the harm from gold-mining to their environment and to people's health, she gave up buying gold. She also stated that she started a campaign in her husband's village, in which she called on the villagers thus: "Let's not buy 
gold for wedding ceremonies. Let's give money to the value of the gold, but not buy gold."

In addition to this, some of Ayşe's words show how her new learning experiences have brought her to question her previous learning practices. Her following words present an example of this:

What they taught us in schools: did they not say to us not to cut trees, to protect forests, and so on? Did they not say to us: plant a tree? If they taught us these things, how can they deforest this region for the sake of corporations' profits?

I thought these things and I said, I would struggle, even if it means death at the end.

Moreover, some of Ayşe's words, and of other participants in the movement that this chapter could not include, show how adults in the movement learn courage, solidarity and hope through their experiences. Ayşe says about this issue that

I have learned here to go hand in hand with people. I have learned about uniting with people in a single heart. If we can do this, we can do everything in Turkey, there is nothing that people cannot succeed in if they struggle together. I struggle here for the sake of the environment, for people and their health. Even if the struggle brings death at the end, I am ready as well. If we die, let's die through the struggle.

The second question provided data about learning experiences of people related to other social movements. Ayşe stated that she also learned many important things related to other movements through the struggle. One dimension of learning from other social movements was related to establishing relationships with other environmental social movements. Through this relationship Ayşe and other people, especially activists in the movement, learned what happened in other regions as a result of gold-mining operations. Since the movement's beginning, it has developed relationships with other movements, and they have visited other regions, and observed what happened there as a result of commercial operations.

Furthermore, some of Ayşe's important learning experiences from other movements were related to the problems and setbacks they experienced. For example, one of the most well-known environmental social movements in Turkey, the Bergama movement, which also occurred in a region close to the Kaz Mountains, taught Ayşe many things. As an example she states that disagreements and factions in this movement brought about the partial failure of the movement and this situation made the Kaz Mountains Social Movement more sensitive about the unity of people. Her following words reflect her thoughts about other movements:

I have learned many things that I did not see and I did not know before. If someone says to me that there is such a struggle in another region, I can go there and support people who struggle there. 
Through the interviews it can be seen that both activists and villager-participants of the Kaz Mountains Environmental Social Movement have learnt through the mediation of various tools such as information meetings, panels, demonstrations, television programs, and newspapers, etc. On the other hand, besides these common channels of information, activists have learned more through visiting other regions and through the internet as well, according to the villager-participants. Ayşe, as an activist, has participated in many panels, meetings and demonstrations in her own town, or in universities and delegations to other regions.

As mentioned above, learning in social movements increases with active participation in the movement, just as Ayşe is one of the active participants of the Kaz Mountains Environmental Social Movement. Her words summarize her learning experiences and the importance of these for her: "Maybe I cannot exactly tell you what, but I have learned many things. I say to myself, my fortune is that I am in the movement and I have taken part in many activities."

\section{CHANGES DUE TO PARTICIPATING IN THE MOVEMENT}

Besides learning experiences, personal changes in their beliefs and changes in interpersonal relations have affected adults due to participating in the movement. Regarding personal change, participants stated different types of changes to themselves such as the development of self-confidence, sensitivity to the environment and nature, changes in their thoughts related to other movements, to new relationships and to collaborating with people from different parts of society. Ayşe has expressed these changes to herself as well as to other participants. As she took on more responsibilities, and as her self-confidence developed, she learned more about the environment and the effects of mining operations and other issues. Ayşe has met many new people as an activist in the struggle. Her increasing sensitivity to the environment and to nature has increased her attention to other social movements as well.

Moreover, as part of the changes to interpersonal relations, besides some general changes in relationships, important changes in gender-based relationships have occurred as well. Ayşe talked about this issue, saying that through the struggle many people have come together with the aim of preventing mining operations. She stated that there were many people who were angry at each other yet they came together and they acted in a united way against the mining corporation. In addition, Ayşe related how through the struggle the social visibility of women in the movement increased.

\section{CONCLUSION}

The fields of adult education and adult learning have been facing important changes in the current period of globalization on account of the neo-liberal policies at work behind it. While market-driven policies and commodification dominate the field, 
the same policies in all other social areas have resulted in the rise of an increasing number of social movements in recent years.

On the one hand, social movements are engines of change in the context of resisting neoliberal policies and generating alternatives. At the same time, social movements are important learning sites for adults, where adults learn 'they can change' if they struggle. While learning experiences in social movements are important for the success of the movements, such experiences provide critical dimensions of adult education for the adults as well. Adults learn for their vital needs in social movements, far from the economistic-based perceptions of adult learning that are so current in our 'globalized world.'

Despite the fact that research into social movements has increased in recent years, researchers in the field of adult education should look still more into social movements. As a developing branch of adult learning, the area of social movement learning provides important tools for the researcher to understand how the learning experiences of adults can be related to adults' vital needs and to their lives. Freire (1973) stated that "Liberation is a praxis: the action and reflection of men and women upon their world in order to transform it" (Freire, 1973, p. 66) where praxis in social movements provides the learning of hope to adults to transform their world.

In this chapter, through the story of a woman activist in the Kaz Mountains Environmental Social Movement, an attempt has been made to show how and what adults learn in action and how their lives change with their learning experiences. The chapter attempted to show that people in Turkey who live in rural areas, who possess low levels of education and work in blue collar occupations, are still far from enjoying unimpeded access to adult education provision. In this context, social movements are important learning sites for people who have not been part of learning activities institutionally. Ayşe's words that "If I had had a lesson through paying money, I do not know if I could have learnt as much as I learned in this struggle," show us how valuable these learning experiences are for her.

\section{REFERENCES}

Cain, M. (1998). Adult learning in two social movement organizations: The role of gender, class, and power (Unpublished dissertation). University of Wisconsin, Madison, WI.

Clover, D. (2003). Environmental adult education: Critique and creativity in a globalizing world. New Directions for Adult Education and Continuing Education, 99, 5-15.

Clover, D. E., \& Hall, B. L. (2000). In search of social movement learning: The growing jobs for living project (WALL Working paper no. 18). Toronto, ON: Centre for the Study of Education and Work, Ontario Institute for Studies in Education, University of Toronto. Retrieved April 25, 2008, from https://tspace.library.utoronto.ca/bitstream/1807/2732/2/18insearchof.pdf

Foley, G. (1999). Learning in social action: A contribution to understanding informal education. London, England: Zed Books.

Freire, P. (1973). Pedagogy of the oppressed (M. Bergman Ramos, Trans.). New York, NY: Continuum. Hill, R. J. (2003). Environmental justice: Environmental adult education at the confluence of oppressions. New Directions for Adult Education and Continuing Education, 99, 27-38. 
Holst, J. D. (2002). Social movements, civil society, and radical adult education. Westport, CT: Bergin \& Garvey.

Holst, J. D. (2004). Globalization and education within two revolutionary organizations in the United States of America: A Gramscian analysis. Adult Education Quarterly, 55(1), 23-40.

Mayo, P. (2003). A rationale for a transformative approach to education. Journal of Transformative Education, 1(1), 38-57.

Mayo, P., \& Borg, C. (2005). The EU memorandum on lifelong learning: Old wine in new bottles? Globalisation, Societies and Education, 3(2), 203-225.

MONE. (2006). 17th Turkish national education council preliminary committee reports. Retrieved December 11, 2008, from http://ttkb.meb.gov.tr/

Okçabol, R. (1997). Globalization and adult education in Turkey. Questions de Formation - Issues in the Education of Adults, 8(15), 49-162.

Öngür, T. (2007). 'Küreselleşen maden hukuku', soL gazetesi, 20 Aralık. Retrieved April 26, 2008, from http://arsiv.sol.org.tr/index.php?yazino=27036

Rizvi, F., \& Lingard, B. (2010). Globalizing education policy. New York, NY: Routledge.

Schugurensky, D. (1997). Forward to past? Globalization, neo-liberalism, and adult education. Questions de Formation - Issues in the Education of Adults, 8(15), 23-52.

Seçkin, O. (2008). Learning in the Kaz Mountains environmental social movement (Unpublished master thesis). Boğaziçi University, İstanbul, Turkey.

Sumner, J. (2008). Governance, globalization, and political economy: Perspectives from Canadian adult education. Adult Education Quarterly, 59(1), 22-41.

Tamzok, N. (2003, Nisan). Küresel politikalar ve Türkiye madencilik sektörü. Liberal Reformlar ve Devlet Sempozyumu, Kigem Ankara.

Turkish Statistical Institute. (2010). Adult education survey 2007 (Publication Number: 3433). Ankara, Turkey: Turkish Statistical Institute Printing Division.

Turkish Statistical Institute. (2013). 31 Temmuz 2013 tarihli haber bülteni. Retrieved January 16, 2014, from http://www.tuik.gov.tr

Walters, S. (2005). Social movements, class, and adult education. New Directions for Adult Education and Continuing Education, 106, 53-56.

\section{Onur Seçkin}

Department of Education

Boğaziçi University, Turkey 